\title{
EFFECT OF PROCESSING PARAMETERS ON TEXTURE, COMPOSITION AND APPLICABILITY OF HIGH PROTEIN DAIRY FOOD
}

\author{
A Thesis presented to the Faculty of \\ California Polytechnic State University, San Luis Obispo \\ In Partial Fulfillment of \\ The Requirements for the Degree of Master of Science in Agriculture
}

By

MAULIK SHAH

March 2009 
COMMITTEE APPROVAL PAGE

TITLE :

EFFECT OF PROCESSING PARAMETERS ON

TEXTURE, COMPOSITION AND APPLICABILITY

OF HIGH PROTEIN DAIRY FOOD

AUTHOR : $\quad$ MAULIK SHAH

DATE SUBMITTED : $\quad$ MARCH 2009

COMMITTEE CHAIR : DR. PHIL TONG, PROFESSOR, DAIRY SCIENCE DIRECTOR, DAIRY PRODUCT TECHNOLOGY CENTER.

COMMITTEE MEMBER : PROFESSOR HEATHER SMITH

STATISTICS DEPARTMENT

COMMITTEE MEMBER : DR. HANY KHALIL, PROFESSOR, FOOD SCIENCE AND NUTRITION DEPARTMENT. 


\section{ABSTRACT \\ EFFECT OF PROCESSING PARAMETERS ON TEXTURE, COMPOSITION AND APPLICABILITY OF HIGH PROTEIN DAIRY FOOD}

\section{MAULIK SHAH}

The purpose of this study was to determine the impact of key process parameters on the flow properties of a novel High Protein Dairy Food (HPDF). HPDF was manufactured by an approach similar to that of manufacture of Halloumi cheese (a semi hard cheese originally from Cyprus). The effect of pasteurization condition, $\mathrm{pH}$ of acidification and homogenization were investigated on flowability, composition and texture of the HPDF. The study consisted of three different stages. After each stage of experimentation, the HPDF was analyzed for compositional, textural (by texture profile analysis) and flow properties during heating by microwave, oven and hot water was measured by Schreiber melt test. The first stage of experimentation screened 18 batches of HPDF under three levels of pasteurization conditions $\left(191^{\circ} \mathrm{F} / 16 \mathrm{sec}, 175^{\circ} \mathrm{F} / 16 \mathrm{sec}\right.$ and $\left.161^{\circ} \mathrm{F} / 16 \mathrm{sec}\right)$, three levels of $\mathrm{pH}$ of acidification (5.8,6.2 and 6.6) and two levels of homogenization conditions (two stage homogenization $(2000$ psi/500 psi) and no homogenization). Based on the results of the first stage, a statistically powerful second stage of experiment was designed in which two levels of pasteurization condition $\left(191^{\circ} \mathrm{F} / 16\right.$ sec and $161^{\circ} \mathrm{F} / 16 \mathrm{sec}$ ) and three levels of $\mathrm{pH}$ of acidification (5.8, 6.2 and 6.6) were employed in duplicate to manufacture HPDF. The third stage of experimental design was to investigate the effect of two-stage homogenization treatment $(2000$ psi/500 psi $)$ with two levels (homogenization and no homogenization).

The results of all three stages of experimentation proved that HPDF made from milk pasteurized under higher pasteurization condition $\left(191^{\circ} \mathrm{F} / 16 \mathrm{sec}\right)$ had significantly higher flow resistance under all three heating conditions. There was significant interaction between $\mathrm{pH}$ of 
coagulation of milk and pasteurization condition on flow properties of HPDF with $\mathrm{pH}$ of coagulation 5.8 restriction flow of HPDF under all three heating conditions. The role of homogenization in restricting flow of HPDF was not significant, although the mean flow of HPDF, made from homogenized milk, decreased. The mean protein content and mean moisture content of HPDF was significantly affected by all three processing conditions, although the mean fat content of HPDF was not influenced by any of these conditions. The mean fat, protein and moisture content of HPDF were in the range of 10.5-11, 26-34 and 47-54 percent respectively. The primary textural properties affected significantly by the processing condition were hardness, chewiness and gumminess. Particularly, hardness was influenced by higher pasteurization condition and lower $\mathrm{pH}$ of acidification.

Further, to judge the consumer acceptability of HPDF, various recipes made out of HPDF with different heating applications (baking, stir-frying and soup) were served to 12 panelists of DPTC. Their opinions were collected and analyzed statistically. The analysis of limited focus group survey showed that consumer liking for HPDF recipe was significantly influenced by prior familiarity with the recipe, although there was some preference for HPDF over tofu due to its 'dairy' flavor. When the texture of HPDF manufactured from milk pasteurized at $191^{\circ} \mathrm{F} / 16 \mathrm{sec}$ and $\mathrm{pH}$ of acidification 5.8 and 6.2 were compared with various commercial protein sources, the hardness of the HPDF was very close to extra firm tofu. All the other textural properties of HPDF were significantly different from firm, silken, baked or reduced fat tofu.

From this project, it is evident that a high protein food, which can be part of day-to-day human diet and potential tofu alternative, can be obtained using halloumi approach by optimizing pasteurization condition $\left(191^{\circ} \mathrm{F} / 16 \mathrm{sec}\right)$ and $\mathrm{pH}$ of coagulation (5.8). 


\section{ACKNOWLEDGEMENTS}

I would like to thank my advisor and committee chair, Dr. Phil Tong of the Dairy Products Technology Center, for all his guidance and support. I am thankful to him for the opportunities I have been given by him throughout my graduate program. I sincerely appreciate his kind support that made this project so enjoyable and worthwhile. I am very grateful to Prof. Heather Smith of the Statistics Department for her understanding and advice as my committee member and for her vigilant and thorough statistical data analysis. I would also like to thank Dr. Hany Khalil for his time and help in finishing my project. I would also like to thank Dairy Management Inc. and California Dairy Research Foundation for the generous financial support for this project.

I am also grateful to Sean Vink for his assistance in pilot plant operation during this project. I would also like to express my gratitude to all the staff and students at the Dairy Products Technology Center at CalPoly, San Luis Obispo.

I dedicate this work to my parents, Upendrakumar Shah and Kaminiben Shah and to my younger brother, Vishant Shah. I am blessed with their unconditional love and support. 
"Only as high as I reach can I grow, only as far as I seek can I go, only as deep as I look can I see, only as much as I dream can I be."

\section{- Karen Ravn}

"The weak can never forgive.

Forgiveness is the attribute of the strong."

- Mahatma Gandhi 


\section{TABLE OF CONTENTS}

$\begin{array}{lll}2 & \text { Page }\end{array}$

LIST OF TABLES XIII

LIST OF FIGURES $\quad$ XVI

LIST OF APPENDICES $\quad$ XXI

Chapter

1.0 INTRODUCTION 1

2.0 LITERATURE REVIEW

$2.1 \quad$ Importance of protein 3

2.2 Protein sources in human diet 3

2.3 Tofu 4

2.3.1 Composition and Yield 5

2.3.2 Manufacture of Tofu 5

2.3.3 Texture Analysis of Tofu $\quad 8$

2.4 Approaches to make milk based tofu alternative 10

2.4.1 Paneer/Queso blanco approach 10

2.4.1.1 Method of Manufacture $\quad 10$

2.4.1.2 Composition and Yield 12

$\begin{array}{lll}2.4 .2 & \text { Ricotta approach } & 12\end{array}$

2.4.2.1 Method of Manufacture 13

2.4.2.2 Composition and Yield 14

$\begin{array}{lll}\text { 2.4.3 Halloumi approach } & 15\end{array}$

2.4.3.1 Method of Manufacture $\quad 15$ 
2.4.4 Patents on restricted flow cheese

2.4.5 Research work leading to idea of HPDF

2.5 Chemical interaction governing heat induced partially acidified gel 19

2.5.1 Heat induced denaturation of whey protein and its association with Casein micelles

2.5.2 Aggregation of casein micelles

2.5.3 Changes during acidification of milk

2.6 Analysis of cheese texture and flow

2.6.1 Texture Profile Analysis

2.6.2 TPA testing of cheese

$\begin{array}{lll}3.3 & \text { Phase III } & 31\end{array}$

4.0 Materials and Methods 32

4.1 Milk for making HPDF 34

4.2 Experimental Design 35 
Chapter Page

4.2.1 Heat treatment, homogenization and acidification effect $\quad 35$

4.2.2 Heat treatment and acidification effect $\quad 37$

4.2.3 Homogenization effect 38

4.3 Manufacture of HPDF 40

4.3.1 Standardization of fat in raw milk 40

4.3.2 Other Ingredients $\quad 41$

4.3.3 Manufacture of HPDF $\quad 41$

4.4 Analysis of HPDF 44

4.4.1 Compositional Analysis $\quad 44$

4.4.1.1 Total Protein content $\quad 45$

4.4.1.2 Moisture content $\quad 45$

4.4.1.3 Fat content $\quad 45$

4.4.2 Texture Profile Analysis $\quad 45$

4.4.3 Analysis of flow properties $\quad 47$

4.4.3.1 Heating in oven $\quad 48$

4.4.3.2 Heating in microwave 49

4.4.3.3 Heating in hot water $\quad 49$

$\begin{array}{ll}\text { 4.5 HPDF preparation method } & 50\end{array}$

4.5.1 Dry heating/baking $\quad 51$

4.5.2 Heating in oil with agitation/stir frying 52

4.5.3 Wet heat/soup making $\quad 52$

4.6 Comparison with commercial tofu and halloumi 53 
4.6.1 Texture Profile Analysis $\quad 54$

4.7 Limited focus group survey on food preparation $\quad 54$

$\begin{array}{lll}4.8 & \text { Statistical Analysis } & 54\end{array}$

5.0 Result and Discussions: $\quad 55$

$\begin{array}{lll}5.1 & \text { Preliminary Trial } & 55\end{array}$

5.2 Heat treatment, homogenization and acidification effect $\quad 58$

5.2.1 Compositional Analysis $\quad 58$

5.2.1.1 Fat content $\quad 58$

5.2.1.2 Protein and moisture content $\quad 58$

$\begin{array}{ll}\text { 5.2.2 Analysis of flow properties } & 70\end{array}$

5.2.3 Analysis of textural properties $\quad 81$

5.2.4 Significance of Experiment Design I 93

5.3 Heat treatment and acidification effect 94

5.3.1 Compositional Analysis $\quad 94$

5.3.1.1 Fat content 94

5.3.1.2 Protein and moisture content 96

5.3.2 Analysis of flow properties $\quad 100$

$\begin{array}{ll}\text { 5.3.3 Analysis of textural properties } & 110\end{array}$

$\begin{array}{lll}5.4 \quad \text { Homogenization effect } & 117\end{array}$

$\begin{array}{ll}\text { 5.4.1 Compositional Analysis } & 117\end{array}$

$\begin{array}{ll}\text { 5.4.1.1 Fat Content } & 117\end{array}$

5.4.1.2 Protein and moisture content $\quad 118$ 
5.5 Comparison of HPDF with commercial tofu and halloumi $\quad 130$

5.6 Limited focus group survey on cooking application 132

$\begin{array}{lll}\text { 6.0 Conclusion and Significance } & 135\end{array}$

$\begin{array}{lll}\text { 7.0 Limitation and Future Research } & 137\end{array}$

$\begin{array}{lll}8.0 & \text { References } & 138\end{array}$

$\begin{array}{lll}9.0 & \text { Appendices } & 146\end{array}$ 


\section{LIST OF TABLES}

Table

Page

2.1 Percent protein in some food 3

2.2 Approximate composition of soybean and tofu 5

2.3 Approximate composition of different types of Ricotta cheese 14

2.4 Chemical composition of halloumi cheese made from sheep or cows milk $\quad 17$ from Cyprus market

2.5 Proportion of $\beta$-lactoglobulin and $\alpha$-lactalbumin complexed with casein $\quad 20$ micelles at various heat treatments

2.6 TPA Texture terms and definitions $\quad 25$

4.1 Experimental design 1 factor and response variable 36

4.2 Experimental design 2 factor and response variable 38

4.3 Experimental design 3 factor and response variable 39

5.0 Preliminary trial on flowability of HPDF under different processing condition 56

5.1 Mean fat content of different HPDF $\quad 61$

5.2 Mean protein content of different HPDF $\quad 62$

5.3 Mean moisture content of different HPDF 63

$5.4 \mathrm{p}$-values of test of significance for mean protein, mean fat and mean moisture 64 at different pasteurization, acidification and homogenization levels

5.5 Mean flowing oven of HPDF under different processing conditions 72

5.6 Mean flowing microwave of HPDF under different processing conditions $\quad 73$

5.7 Mean flowing hot water of HPDF under different processing conditions $\quad 74$ 
5.8 p-values of test of significance of mean flowing in oven, hot water and microwave at different acidification, pasteurization and homogenization levels.

5.9 Effect of processing parameter on mean hardness, mean gumminess and mean 83 Chewiness of HPDF

5.10 Effect of processing parameter on mean chewiness and mean springiness $\quad 84$ of HPDF

$5.11 \mathrm{p}$-values of test of significance of mean hardness, cohesiveness and springiness, gumminess and chewiness at different acidification, pasteurization and homogenization levels.

5.12 Effect of heating conditions and acidification on mean fat content of HPDF 94

5.13 Effect of heating conditions and acidification on mean protein content 96 of HPDF

5.14 Effect of heating conditions and acidification on mean moisture content $\quad 98$ of HPDF

$5.15 \mathrm{p}$-values of test of significance for mean protein, mean fat and mean 99 moisture at different acidification and pasteurization conditions

5.16 Effect of heating condition and acidification on mean flow in oven of HPDF 103

5.17 Effect of heating condition and acidification on mean flow in microwave 104 of HPDF

5.18 Effect if heating condition and acidification on mean flow in hot water 105 of HPDF 
5.19 p-value of test of significance of mean flowing of HPDF in oven, microwave 106 and hot water at different acidification and pasteurization conditions

5.20 Effect of $\mathrm{pH}$ of acidification and heating condition on mean hardness, gumminess and chewiness of HPDF

5.21 Effect of $\mathrm{pH}$ of acidification and heating condition on mean cohesiveness And mean springiness of HPDF

5.23 Effect of homogenization on mean fat content of HPDF

5.24 Effect of homogenization on mean protein content of HPDF

5.25 Effect of homogenization on mean moisture content of HPDF

$5.26 \mathrm{p}$-value for test of significance for homogenization on mean fat, protein And moisture content of HPDF

5.27 Effect of homogenization on mean flow of HPDF in oven

5.28 Effect of homogenization on mean flow of HPDF in microwave microwave and hot water at different acidification and homogenization conditions. 


\section{LIST OF FIGURES}

Figure

PAGE

$\begin{array}{ll}\text { 2.1 Process flow chart for tofu production } & 7\end{array}$

2.2 Process flow chart for manufacture of Paneer/Queso Blanco 11

2.3 Process flow chart for manufacture of Ricotta cheese 13

2.4 Process flow chart for manufacture of halloumi cheese 16

2.5 Texture Profile Analysis of cheese $\quad 24$

2.6 TA-XT2 texture analyzer 26

$\begin{array}{ll}\text { 2.7 Schreiber flow test } & 29\end{array}$

4.1 Microstructure of HPDF made by halloumi approach 32

4.2 Microstructure of HPDF made by Paneer/Queso Blanco approach 33

4.3 Flow chart for experiment design 1: effect of heat treatment, homogenization 37 and acidification on chemical, textural and flowing quality of HPDF

4.4 Flow chart for experiment design 2: effect of heat treatment and acidification 38 on chemical, textural and flowing quality of HPDF

4.6 Flow chart for experimental design 3: effect of homogenization on chemical, 40 textural and flowing quality of HPDF

$4.7 \mathrm{pH}$ meter with special food grade electrode 42

4.8 Flow chart of manufacture of HPDF 43

4.9 Texture Profile of HPDF obtained from TA-XT2 texture analyzer at room 46 temperatures on $2 * 2 * 2 \mathrm{~cm}$ sample

4.10 Sample of HPDF subjected to heat treatment 47

4.11 Sample of HPDF heated in convection oven at $450^{\circ} \mathrm{F}$ for $15 \mathrm{~min} \quad 48$ 
4.12 Sample of HPDF heated in microwave for $1 \mathrm{~min} \quad 49$

4.13 Sample of HPDF heated in hot water for $10 \mathrm{~min} \quad 50$

4.14 Flow chart of baking of HPDF 51

4.15 image of baked HPDF

4.16 Flow chart of stir-frying of HPDF 52

4.17 Flow chart of making of miso soup from HPDF 53

4.18 Image of miso soup HPDF 53

5.0 Preliminary trial on effect of processing condition on flowability of HPDF $\quad 57$

5.1 Effect of heating conditions on mean moisture and mean protein of HPDF $\quad 65$

5.2 Effect of $\mathrm{pH}$ of acidification on mean moisture and mean protein of HPDF 66

5.3 Effect of homogenization on mean moisture and mean protein of HPDF $\quad 67$

5.4 Main effects plots for mean moisture vs. pasteurization condition, $\quad 68$ homogenization and $\mathrm{pH}$ of acidification

5.5 Interaction plot for mean moisture vs. pasteurization condition, $\quad 68$ homogenization and $\mathrm{pH}$ of acidification

5.6 Main effects plot for mean protein vs. homogenization, pasteurization $\quad 69$ and $\mathrm{pH}$ of acidification

5.7 Interaction plot for mean protein homogenization, pasteurization 69 and $\mathrm{pH}$ of acidification

5.8 Effect of heating conditions on flowing under oven, microwave and 76 hot water 

hot water

5.10 Effect of heating conditions on flowing under oven, microwave and hot water

5.11 Main Effects plot for mean flowability in oven vs. pasteurization

5.14 Effect of heating condition on hardness, gumminess and chewiness of HPDF 85

5.15 Effect of heating condition on cohesiveness and springiness of HPDF 86

5.16 Effect of $\mathrm{pH}$ of acidification on hardness, gumminess and chewiness of $\quad 87$ HPDF

5.17 Effect of acidification on cohesiveness and springiness of HPDF

5.18 Effect of homogenization on hardness, gumminess and chewiness of HPDF 89

5.19 Effect of homogenization on cohesiveness and springiness of HPDF $\quad 90$

5.20 Main Effects plot for mean hardness vs. pasteurization $\quad 91$

5.21 Main Effects plot for mean gumminess vs. pasteurization 92

5.22 Interaction Plot for mean hardness vs. pasteurization, $\quad 92$ $\mathrm{pH}$ of acidification and homogenization

5.23 Interaction Plot for mean gumminess vs. pasteurization, $\mathrm{pH}$ of acidification and homogenization and mean moisture content of HPDF 
Figure $\quad$ Page

5.25 Main Effects Plot for mean protein vs. pH of acidification 99

5.26 Interaction Plot of mean protein vs. pH of acidification and 100 pasteurization condition

5.27 Interaction Plot of mean moisture vs $\mathrm{pH}$ of acidification and 100 pasteurization condition

5.28 Interaction Plot for flow in oven vs. pH of acidification and 106 pasteurization condition

5.29 Interaction Plot for flow in microwave vs. pH of acidification and 107 pasteurization temperature

5.30 Interaction Plot for flow in microwave vs. pH of acidification and $\quad 107$ pasteurization temperature

5.31 Effect of $\mathrm{pH}$ of acidification on mean flow value of HPDF manufactured 108 from milk pasteurized at $191^{\circ} \mathrm{F} / 16 \mathrm{sec}$.

5.32 Effect of $\mathrm{pH}$ of acidification on mean flow value of HPDF manufactured $\quad 109$ from milk pasteurized at $161^{\circ} \mathrm{F} / 16 \mathrm{sec}$.

5.33 Effect of $\mathrm{pH}$ and heating condition on mean hardness, mean gumminess $\quad 112$ and mean springiness of HPDF

5.34 Effect of pH and heating condition on mean cohesiveness and mean 114 springiness of HPDF

5.35 Interaction Plot for hardness vs. pasteurization condition and $\mathrm{pH}$ of $\quad 115$ acidification 
Figure

Page

5.36 Interaction Plot for cohesivess vs. pasteurization condition and $\mathrm{pH}$ of

115

Acidification

5.37 Interaction Plot for gumminess vs. pasteurization condition and $\mathrm{pH}$ of

116 acidification

5.38 Main Effect Plot of chewiness vs. pasteurization temperature

116

5.39 Interaction Plot for mean protein vs. homogenization and $\mathrm{pH}$ of acidification 122

5.40 Effect of Homogenization and $\mathrm{pH}$ of acidification on mean protein and 123 mean moisture percent of HPDF.

5.41 Main Effects Plot for mean flow in microwave vs. $\mathrm{pH}$ of acidification $\quad 128$

5.42 Effect of homogenization and $\mathrm{pH}$ of acidification on mean flow value of 129 HPDF

5.43 Comparison of HPDF with commercial protein rich sources

5.44 Consumer preference of tofu/HPDF on baking, soup-type and

133 stir-frying application

5.45 Influence of consumer's familiarity of recipe over preference 


\section{LIST OF APPENDICES}

$\begin{array}{lll}\text { Appendices } & \text { Page }\end{array}$

1. Experimental Design I Statistical Analysis 146

1.1 General Linear Model for mean fat, mean protein and mean moisture 146

1.2 General Linear Model for mean flow in oven, microwave and hot water 152

1.3 General Linear Model for mean hardness, mean cohesiveness, mean 158 springiness, mean gumminess and mean chewiness

2. Experimental Design II Statistical Analysis 167

2.1 General Linear Model for mean fat mean protein and mean moisture 167

2.2 General Linear Model for mean flow in oven, microwave and hot water 172

2.3 General Linear Model for mean hardness, mean cohesiveness, mean 181 springiness, mean gumminess and mean chewiness

3. Experimental Design III Statistical Analysis 191

3.1 General Linear Model for mean fat mean protein and mean moisture 191

3.2 General Linear Model for mean flow in oven, microwave and hot water 194

3.2 General Linear Model for mean hardness, mean cohesiveness, mean 198 springiness, mean gumminess and mean chewiness

4. Limited group Statistical Analysis 205

5. Limited focus group Questionnaire 207

$\begin{array}{ll}5.1 \text { Baking } & 207\end{array}$

$\begin{array}{ll}\text { 5.2 Miso Soup making } & 208\end{array}$

$\begin{array}{ll}\text { 5.3 Stir frying } & 209\end{array}$ 


\subsection{Introduction}

There is considerable interest among food manufacturers to design novel dairy based foods that convey at least some of the sensory properties of foods that consumers are already familiar with(such as cheddar, mozzarella, monterery jack cheeses), but for which the flow properties have been customized to meet the specific processing and preparation requirements of the final food product.

In some dairy based food applications, restriction of flow properties of food is highly desirable. For example, the addition of cheese to a frozen meat product designed to be cooked or reheated may be problematic if the cheese flows and runs off the meat before the meat is fully cooked or reheated. Flow restriction is also desirable for cheese used inside a bakery item which is cooked at high temperature. Cheese can also "blow out" and leak into oil when it is used in case of deep-fried snacks. Sometimes it is desirable to retain the shape and textural identity of dairy foods when the food is incorporated into canned soups, pasta sauces, pizza or other processed food products that are subjected to high preparation temperatures.

In addition, food manufacturers also have an interest in developing food products that are devoid of ingredients not normally associated with the food in question. Examples of such may include food additives such as stabilizers, gums, whey proteins and other such food ingredients. Therefore, an advantage to design food products that have "natural" designation and that are free of unconventional components or ingredients that consumers normally would not associate with such a food product.

In this project, a process to manufacture high protein food completely based on milk, with restricted flow properties, was developed. The properties of the high protein dairy based food resemble some characteristics of soy bean curd, tofu. The food has potential to capture part of tofu 
market. The tofu market is now valued just about \$244 million in 2007 in US (U.S. Market 2008, Soyatech Inc. and SPINS). The acceptability of such a tofu alternative high protein food is very high due to health benefits associated with high protein diet.The meat-like texture of this product will open up a vegetarian protein based diet, which is cheaper and healthier than meat. In addition, it will also impart the milky flavor to consumers, who do not prefer bland taste of tofu.

The aim of this study was to determine process variables that affect the flow of High Protein Dairy Food (HPDF). 


\subsection{Literature Review}

\subsection{Importance of Protein}

Amino acids, the building blocks of protein, are necessary for formation and maintenance of cells, function of enzyme, hormonal and immune system. The human body can synthesize 11 amino acids out of 20 primary amino acids and hence these are called non-essential amino acids whereas the remaining 9 amino acids are obtained only from the food and they are called essential amino acids. The essential amino acids are supplemented through various dietary sources.

\subsection{Protein Sources in Human Diet}

There are two types of dietary protein sources: 1. Animal dietary protein sources: meat (beef, lamb, and pork), poultry, eggs, and seafood, milk and milk products. 2. Vegetable dietary protein sources: nuts, soy foods, sprouted seeds, grains, beans and legumes. The percentage protein in some of these dietary sources of protein is as per Table 2.1 .

Table 2.1 Percentage protein in some foods (Source: http://www.dietaryfiberfood.com/food-protein-sources.php)

\begin{tabular}{|l|c|}
\hline Food & Percent Protein by Weight \\
\hline Soybeans (whole, dry) & 35 \\
\hline Cheeses & 35 \\
\hline Chicken & 21 \\
\hline Fish & 22 \\
\hline Beef (steak) & 20 \\
\hline Hamburger & 13 \\
\hline Eggs & 13 \\
\hline Tofu & 8 \\
\hline Milk (whole) & 3 \\
\hline
\end{tabular}


From the table, it is clear that soy beans are valued as excellent source of good quality protein (Wang and Cavins, 1969). In Asia, soy beans have contributed to an important part of human diet for centuries (Coppock, 1974, Norman 1978) mainly as soy milk and associated products like tofu, tempeh, miso, natto and soy sauce. Tofu is one of the most widely known sources of protein in Asia. The purpose of this study was to study the processing effects on a dairy based high protein tofu alternative. Hence it is vital to study properties of tofu, its manufacturing process, yield and composition.

\subsection{TOFU}

Tofu was invented in China during Han dynasty over 2000 years ago. It is a high protein food widely consumed in Asia (Hou and Chang, 2004 and Chang, 2006). Tofu, also known as soy curd, is a soft cheese-like food made by curdling soy milk with a coagulant. Tofu is a rather bland tasting product that easily absorbs the flavors of the other ingredients. Tofu is sold in water-filled packs or in aseptic cartons. Fresh tofu is usually packaged in water and should be refrigerated and kept in water until used. Depending upon the texture and usage, several types of tofu are available in market. For example, firm tofu is hard and can be stir-friend, cubed, grilled, scrambled, pickled, barbecued, baked, smoked or served in soup. Soft tofu is more suitable in recipes where tofu requires to be blended. Silken tofu is creamy in texture and is also used in blended tofu recipes.

In North America, tofu consumption is increasing due to increase in Asian population (Lim et al., 1990) and acceptance by general public due to the claimed health benefits of soy foods. The claimed health benefits associated with consumption of tofu include reducing risk of cardiovascular diseases, preventing certain cancers, reducing postmenopausal syndromes and increasing bone mass density (Messinna, 2004 and Chang, 2002). 


\subsubsection{Composition and Yield}

The yield and composition of tofu varies depending upon factors such as use of different varieties of soybeans, initial solid content of soy milk, use of different coagulants, coagulation temperature, moisture content, processing errors, losses of soluble matters during pressing and washing of soybean curd. Deman et al. (1987) reported the yield of tofu from the different varieties of soybean grown in Canada is between 20.9-27.3 per cent. The maximum solid recovery was obtained when calcium sulphate was used as coagulant (98.5-110.0\%) followed by magnesium sulphate (86-93.5\%), magnesium chloride (83-91.4\%) and calcium chloride (83-89.2\%) respectively. When soy milk was coagulated at different temperatures $\left(60,70,80^{\circ} \mathrm{C}\right)$, the total solids remained about the same (Wang and Hesseltine, 1982). Approximate composition of soybean and tofu (on dry weight basis) is as per Table 2.2.

Table 2.2 Approximate composition of soybean and tofu (Pant et al., 1993)

\begin{tabular}{|l|c|c|}
\hline Composition & Soybean & Tofu \\
\hline \% Moisture & 90 & 65.7 \\
\hline \% Protein (on dry weight) & 43.9 & 57.8 \\
\hline \% Fat (on dry weight) & 23 & 24 \\
\hline \% Ash (on dry weight) & 6.5 & 4 \\
\hline
\end{tabular}

\subsubsection{Manufacture of Tofu}

Tofu manufacturing requires a series of operations. Depending upon the desired texture, tofu is classified as extra-firm, firm, soft and silken and processing of soymilk is carried out accordingly. Generally, three steps are critical in determining product type: a) soymilk extraction and solid content b) coagulation method c) pressing. The traditional Chinese method separates raw soymilk 
from okara (residue) before heating. In the Japanese method, heating the go (slurry) prior to separation facilitates soymilk extraction and increases tofu yield. Both Chinese and Japanese methods for extracting soymilk are known as traditional Oriental methods because of the presence of beany flavor in the tofu. The General flow chart of tofu manufacture is as per Figure 2.1(Deman et al., 1986).

The heating of soy milk prior to coagulation tends to unfold the polypeptide chains of soy protein (Wolf et al., 1971). Furthermore, heating increases the number of sulfhydryl groups in major soy protein (Saio et al, 1979) since most of the sulfhydryl groups in soy protein are in the disulfide linkage and only a small portion is in free sulfhydryl groups (Escueta et al., 1986). These proteins are macromolecules with molecular weight of around 360,000 Daltons.

The four types of soy proteins are $2 \mathrm{~S}, 7 \mathrm{~S}, 11 \mathrm{~S}$ and $15 \mathrm{~S}$. Main soy proteins responsible for texture of tofu are $7 \mathrm{~S}$ and $11 \mathrm{~S}$ accounting for $30 \%$ and $40 \%$ of total soy proteins respectively (Utsumi, 1985). The 7S protein is sticky whereas the 11S is firm. The unfolding of these globular proteins creates a backbone structure for the three dimensional network of tofu curd (Furukawa et al., 1979).

The $11 \mathrm{~S}$ protein and ratio of $11 \mathrm{~S} / 7 \mathrm{~S}$ correlate positively with hardness of tofu, on the contrary, Skurray et al. (1990) found little correlation between the ratio of 11S/7S protein and tofu quality. Hence, the contribution of soy proteins to tofu texture is controversial and still needs further investigation. 


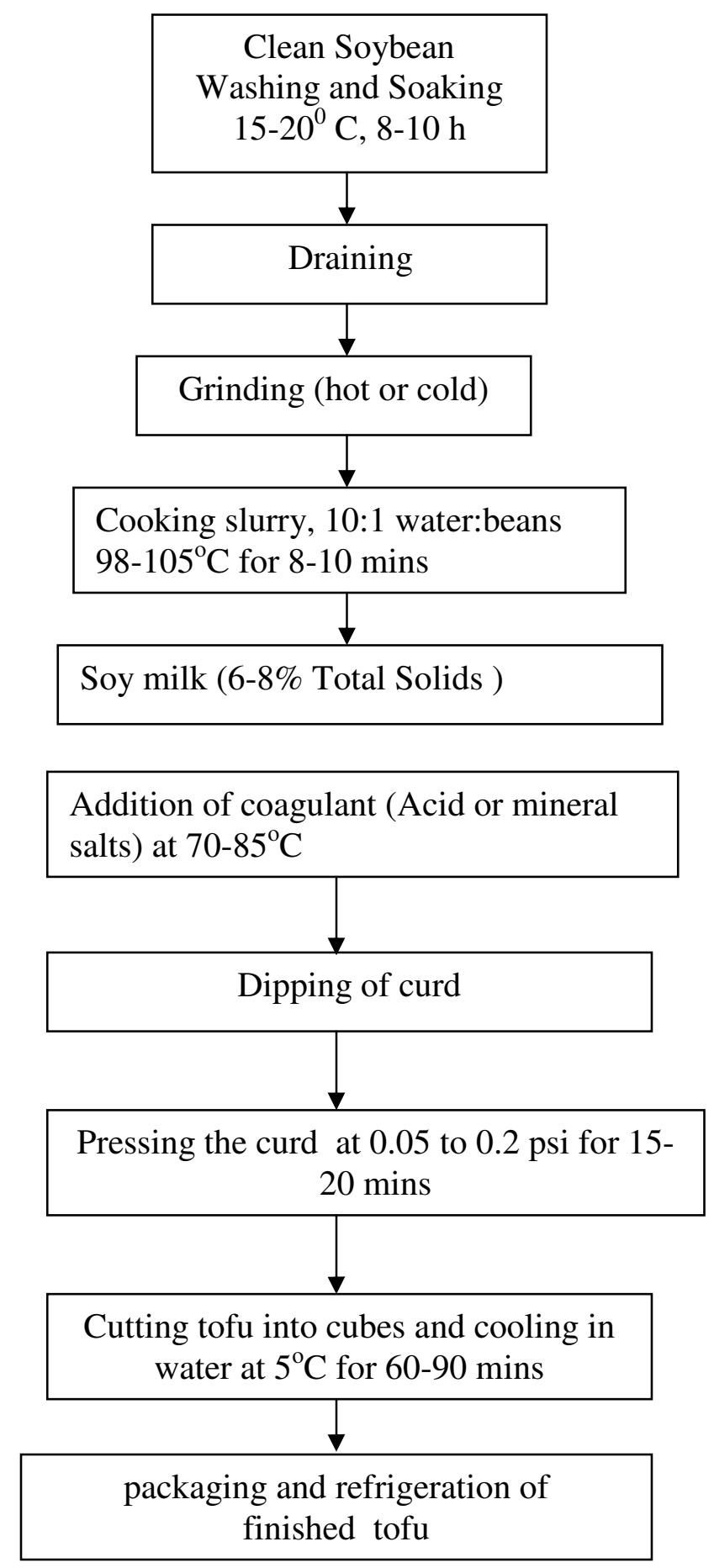

Figure 2.1 Process flow chart of tofu production 
Texture of Tofu is significantly affected by the type of coagulant used. Coagulants such as gluconic acid or calcium and magnesium salt are often used. Wang and Hesseltine (1982) suggested that uniform tofu could be produced if a given variety of soybeans and a selected set of conditions were always used. They suggested using $0.02 \mathrm{M}$ calcium sulfate as the coagulant and $70^{\circ} \mathrm{C}$ as the coagulation temperature to obtain a higher recovery of nitrogen and produce tofu that was firm but not hard.

\subsubsection{Textural Analysis of Tofu}

The texture profile analysis (TPA) has been used as an important objective method for food texture analysis (Bourne 1968, Szezesniak 1987). TPA of tofu is known to be influenced by factors such as processing conditions (Tsai et al, 1981, Escueta et al., 1986), coagulants (Vijaynanda et al., 1989) and chemical composition (Szezeniak 1987) and storage conditions (Gandhi and Bourne 1988).

Different protocols were used by different researchers in conducting the texture analysis of tofu. Obatolu (2008) ran the texture profile analysis based on the procedure described by Bourne (1978) on three tofu samples vertically cut from a block of tofu curd using a cylindrical cutter (25 mm diameter). They used a Stable Micro System, model TA-XT2 (Texture Technologies Corp.) as shown in Figure 2.6 to perform the TPA. The samples were compressed twice to $25 \%$ of its original height with a metal disc $(60 \mathrm{~mm}$ diameter). Hardness, brittleness and chewiness were measured using the software provided with the Texture Analyzer. The method was able to prove statistically that tofu coagulated with lemon juice is significantly softer $(\mathrm{p}<0.05)$ and more fragile than tofu coagulated with other coagulants such as calcium sulphate, epson salt and top water with fermented maize coagulated tofu. (Obatolu (2008) 
Schaefer and Love (1992) did TPA on tofu using Instron Universal Testing Machine (model 1122 ) with a $500 \mathrm{Kg}$ load cell to test the effect of composition of soybean on tofu texture. Cubes of tofu measuring $2 \mathrm{~cm}$ per side were used as samples. The samples were compressed to $25 \%$ of original height two times at a crosshead speed of $200 \mathrm{~mm} / \mathrm{min}$. Hardness, fracturability, chewiness and springiness were calculated from the TPA curves as described by Bourne (1968). Among all the parameters, hardness and springiness were found most variable. The main objective was to study relationship between soybean, soymilk and tofu protein, lipid, phytic acid, calcium, copper and copper. Soybean phytic acid was found to be significantly correlated with tofu calcium $(r=0.90)$. Tofu calcium and hardness $(r=0.73)$ and springiness $(r=0.83)$ were significantly related and tofu protein was significantly related to fracturability $(r=0.75)$.

Yuan and Chang (2007) used TPA method suggested by Bourne (1982) with an Instron universal testing machine (model 1011) on refrigerated tofu. The diameter of cylindrical tofu sample was $44 \mathrm{~mm}$ and the height was $1.5 \mathrm{~cm}$. The experimental design involved 2 level of plunger penetration (50\% and 75\% compression) and 4 compression crosshead speeds (20, 60, 100, 200 $\mathrm{mm} / \mathrm{min}$ ). The temperature of tofu during the textural analysis was approximately 10 to $15^{\circ} \mathrm{C}$. TPA parameters, including hardness, fracturability, springiness, cohesiveness and gumminess, were calculated according to the method of Bourne (1982). The parameters, on 13 different commercial tofu, were correlated with sensory scores and the results were compared. Based on the results, the researchers recommended a combination of $75 \%$ compression and $100 \mathrm{~mm} / \mathrm{min}$ of crosshead speed for the TPA analysis of no-skin tofu.

Based on the above studies, the textural characteristic of tofu is affected by sample geometry, temperature, test conditions, type of test instrument and software used for the measurement. TPA methods suggested by Bourne (1968) are widely used in the industry, however in case of tofu, 
hardness and firmness are the most important textural quality. Texture Profile Analysis is discussed in detail in section 2.4 .

\subsection{Approaches to make milk base tofu alternative}

Several cheeses are made throughout the world which have the characteristic non-flowing property under different cooking applications like stir frying, baking, boiling in hot water/liquid, deep oil frying, grilling etc. In general, all of these approaches of cheese making involved high heat treatment of milk $\left(>175^{\circ} \mathrm{F} / 15 \mathrm{sec}\right.$. or higher) followed by acidification. The high heat treatment causes the denaturation of whey protein (specially $\beta-\lg$ ) and complex formation with $\kappa$-casein (Sawyer, 1969) and subsequently co-precipitates upon acidification of milk at low pH. In this section, three major approaches have been reviewed.

1. Paneer/Queso Blanco Approach

2. Ricotta Approach

3. Halloumi Approach

\subsubsection{Paneer/Queso Blanco Approach}

Queso Blanco, or white cheese, is a broad term describing a group of cheese widely consumed in Latin America and Caribbean countries. Cheese similar to Queso Blanco is also manufactured in India and Pakistan and is popularly known as Paneer. Queso Blanco was first introduced in USA in 1958 (Weigold, 1958) and since standardization of its method of manufacture and effect of various processing condition on characteristics of final product has been an area of interest for researchers in USA and Canada (Torres and Chandan, 1981).

\subsubsection{Method of manufacture}

The manufacturing procedure involves acidification of heated whole, low-fat, skim or recombined milk by lime juice, citric acid solution, sour whey or lactic culture. Milk containing $6 \%$ fat has been 
recommended for best quality Paneer (Warner, 1976). Flow chart of manufacture of Paneer/Queso Blanco is as per Figure 2.2.

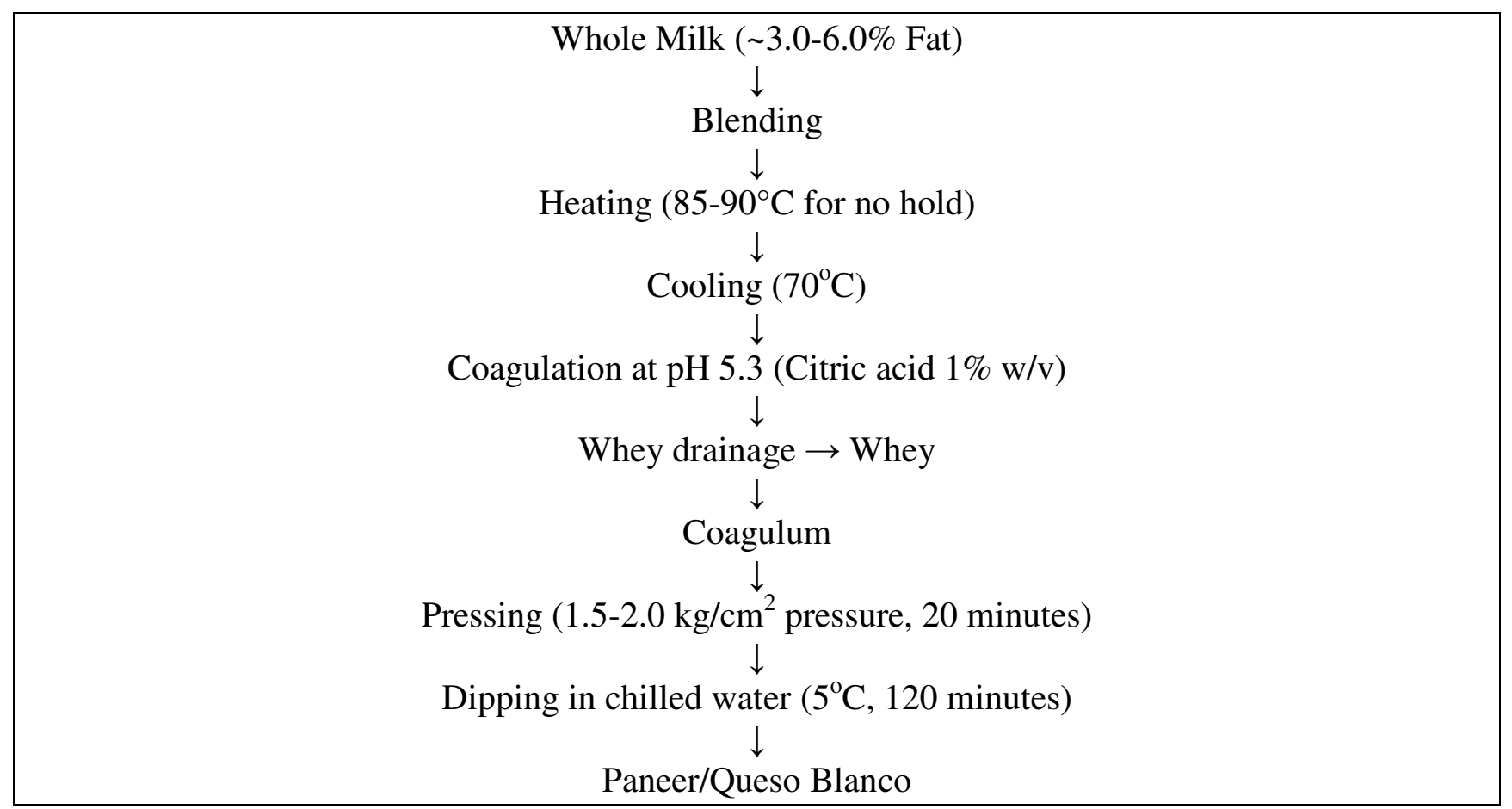

Figure 2.2.Process flow chart for the manufacture of Paneer/Queso Blanco (De, 1998).

The standardized method for large scale Paneer manufacture is described as: fresh, sweet, buffalo milk is filtered and standardized to $3.5-4.0 \%$ fat. It is then heated in a cheese vat to $82^{\circ} \mathrm{C}$ for 5 min and then cooled to $70^{\circ} \mathrm{C}$. The milk is coagulated by the addition of citric acid or sour whey. When it has coagulated completely, the stirring is stopped and the curd allowed to settle for $5 \mathrm{~min}$. The whey is then drained out through a muslin cloth. During this period the temperature of whey is not allowed to fall below $65^{\circ} \mathrm{C}$. The coagulated mass is collected and filled in hoops with cloth linings and then pressed (with a weight of 45-50 kg. placed over wooden planks) for 15-20 min. The pressed paneer is now removed from the hoop, cut into the required sizes for sale and immersed in chilled water $\left(4-6^{\circ} \mathrm{C}\right)$ for $2-3$ hours to make it firm. Hill et al. (1982) suggested that coagulation with an appropriate concentration of citric acid at $\mathrm{pH}$ 5.2-5.3 gave the best quality of Queso Blanco 
cheese made with milk containing $4.5 \%$ fat and $15 \%$ SNF. Addition of calcium chloride (up to $0.05 \%$ ) was helpful to maximize yield and make up the loss of calcium during acidification. ParnellClunies et al. (1985) showed that heat treatment of $85^{\circ} \mathrm{C}$ for $5 \mathrm{~min}$ gave the cheese acceptable flavor, improved body and texture at $\mathrm{pH} 5.3$. Salt $(2-2.5 \% \mathrm{w} / \mathrm{w})$ is added to Queso Blanco curd, at the time of whey removal to increase the shelf-life of the cheese.

\subsubsection{Composition and Yield}

Fresh Queso Blanco has an average composition of 15-20\% fat, 21-25\% protein, 50-56\% moisture, $2-2.5 \%$ salt, $2.5-2.7 \%$ lactose and a ph in the range of 5.2-5.5. It contains approximately 341,357 and $665 \mathrm{mg} \mathrm{Ca}, \mathrm{P}$ and $\mathrm{Na}$ respectively, per $100 \mathrm{~g}$ (Torres and Chandan, 1981). The composition of Paneer depends on whether it is made from bovine, buffalo or mixed milk. Paneer made from cow milk containing $3.5 \%$ fat has $55 \%$ moisture, $19 \%$ fat, $21 \%$ protein, $2 \%$ lactose, $1.6 \%$ Ash and $5.6 \mathrm{pH}$ (Mistry et al., 1992). The composition of Paneer made from buffalo milk is $51 \%$ moisture, $18 \%$ protein, $27 \%$ fat, $2 \%$ lactose and $1.8 \%$ ash (Chandan, 1991; Rao et al., 1992)

There seems to be a large variation in the yield (11.5-22\%) of Queso Blanco depending upon the fat content of milk (3-6\% fat) (Siapantas and Kosikowski, 1965). This shows mechanical occlusion of fat in heat-acid coagulated milk protein and indicates an upper limit of $4.5 \%$ fat or a protein:fat ration of 1:1.2 for the production of acceptable Queso Blanco with high yields (Hill et al., 1982). In case of Paneer, the yield is $20-24 \%$ depending upon the initial fat content of milk. This yield corresponds to 63-67\% milk solids recovery in Paneer.

\subsubsection{Ricotta Approach}

Ricotta cheese is an unripened soft variety of cheese popular in Italy. It has slightly sweet flavor and delicate texture (Di Luccia et al., 1994). Traditionally, Ricotta is manufactured from a blend of cheese whey and whole milk or skim milk. However, to produce Ricotta with desirable curd 
handling characteristics, it is recommended that at least 5 part of whole milk or skim milk should be added to 95 parts of whey (Shahani, 1979). The USDA specifies three types of Ricotta cheese:

1. Whole milk Ricotta: manufactured from whole milk, and the finished product shall contain not more than $80.0 \%$ moisture and not less than $11.0 \%$ milk fat.

2. Part-skim Ricotta: manufactured from milk with a reduced fat content, and the finished product shall contain not more than $80.0 \%$ moisture and less than $11.0 \%$ but not less than $6.0 \%$ milk fat.

3. Ricotta (Ricottone) from whey or skim milk: manufactured from skim milk, whey or a blend of these products and the finished product shall contain not more than $82.5 \%$ moisture and less than $1.0 \%$ milk fat.

Flow chart for manufacture of Ricotta is as per Figure 2.3.

\subsubsection{Method of Manufacture}

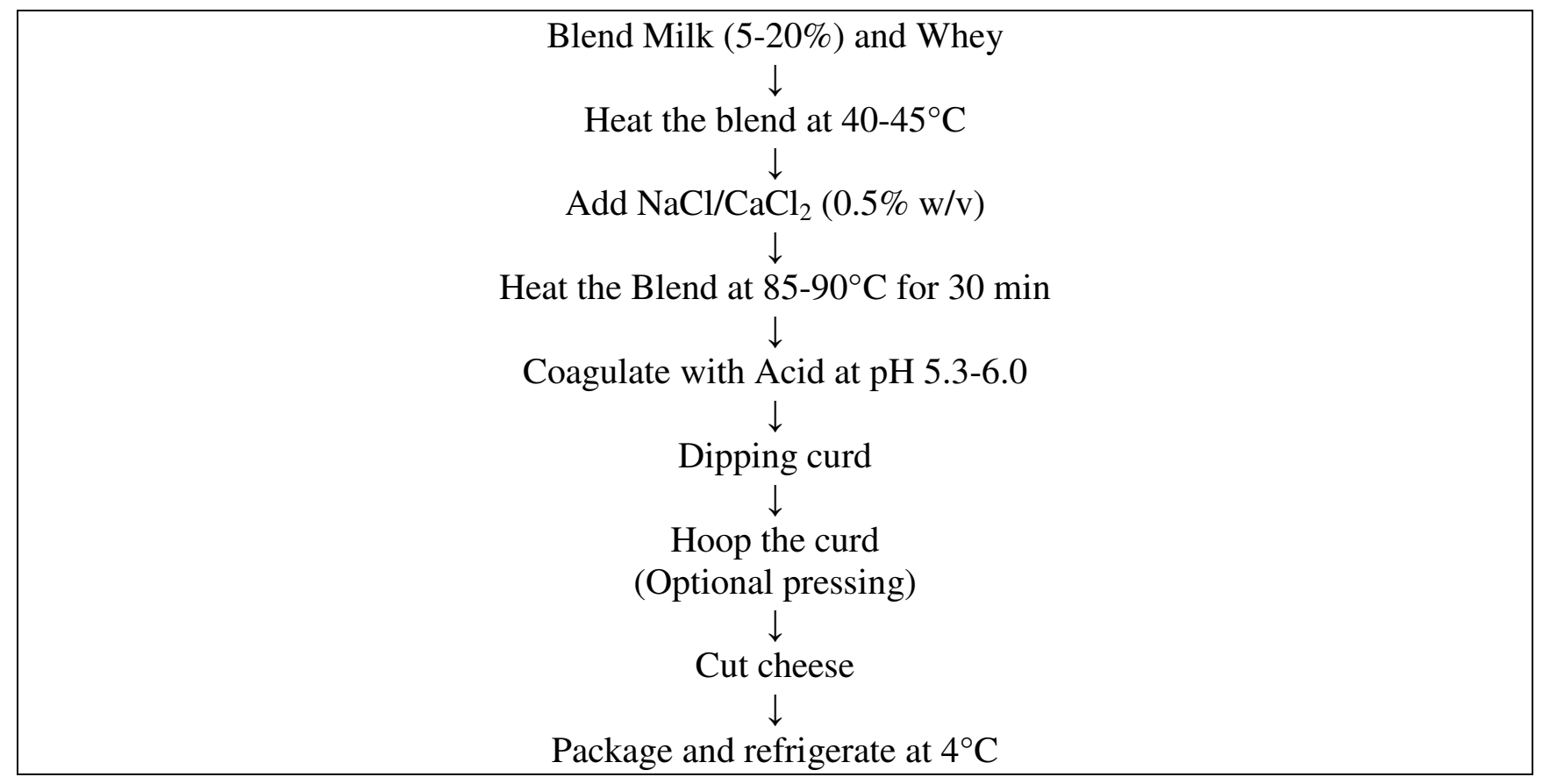

Figure 2.3 Process Flow chart for manufacture of Ricotta cheese (Guinee et al., 1993)

Traditionally, the starting material used is whey resulting from Mozzarella cheese production. The whey titratable acidity should be $\leq 0.16 \%$ lactic acid and its $\mathrm{pH} \geq 6.0$. Industrially, the whey is first 
neutralized to $\mathrm{pH}>6.5(6.9-7.1)$ with a $25 \%(\mathrm{w} / \mathrm{v})$ solution of $\mathrm{NaOH}$. The neutralization serves to minimize protein aggregation and produces a more cohesive coagulum (Modler and Emmons, 1989). There is also evidence of use of cream in stead of whole milk. An increase in casein content by addition of non fat dry milk provided a better firmness in ricotta and the curd became more adhesive. Condensing cheese whey prior to Ricotta cheese making showed a consistent percent recovery of protein. A higher degree of condensing rate in starting whey resulted in higher protein content in cheese. However, use of whey concentrates containing up to $36 \% \mathrm{DM}$ as starting material can be used (Nilson and Streiff, 1978). The purpose of adding salt is to destabilize whey protein followed by addition of food grade acid (acetic acid/citric acid) for final coagulation.

\subsubsection{Composition and Yield}

In continuous manufacturing process of Ricotta, the yield is reported to be between $12-15 \%$. The typical composition of whole milk and part-skim milk ricotta are as per Table 2.3.

Table 2.3 Approximate composition of different types of Ricotta cheese

\begin{tabular}{|l|c|c|}
\hline \multirow{2}{*}{ Component } & \multicolumn{2}{|l|}{ Ricotta cheese variety } \\
\cline { 2 - 3 } & Whole Milk & Part-skim \\
\hline Moisture (\%) & 72 & 74.5 \\
\hline Fat (\%) & 13 & 8 \\
\hline Protein (\%) & 11 & 11.5 \\
\hline Lactose (\%) & 3 & 5 \\
\hline Energy (kcal/100 g) & 174 & 138 \\
\hline
\end{tabular}

Ricotta has a relatively short shelf-life - about 3 weeks if packaged under vacuum, gas flushed and stored at $4^{\circ} \mathrm{C}$ or lower (True, 1973), although Kosikowski (1967) reported a shelf-life of 70 days for whole milk.

\subsubsection{Halloumi Approach}


Halloumi is a semi-hard to hard, unripened cheese that is made from sheep's milk or goat's milk or a mixture of the two, traditionally. Recently, researchers have used cow's milk to manufacture Halloumi, and the end result is quite acceptable. Although the cheese has its origin in Cyprus, it is widely popular throughout Middle East. The texture of the cheese is compact and unyielding to applied pressure. The color of the cheese varies from white (when ovine or caprine milk is used) to distinctly 'yellowish' (when bovine milk is used) (Robinson, 1991). It can be consumed raw, but it is usually grilled, fried or grated over a hot dish. When halloumi is heated, the stretch and flow characteristics are markedly different from the raw halloumi. Upon heating, the flowing characteristics of halloumi are at par with that of molten mozzarella cheese.

\subsubsection{Method of Manufacturing}

The industrial method of manufacturing Halloumi from cow's milk has been accessed during numerous studies and is now controlled by regulations from Government bodies. The flow diagram for manufacturing of Halloumi industrially is shown in figure 2.4 (Robinson, 1991).The crucial step in the manufacturing process of halloumi is the cooking stage.

By law, the blocks of halloumi cheese must be heated for at least 30 minutes at a temperature greater than $90^{\circ} \mathrm{C}$. After this stage, the cheese attains the 'chicken breast' characteristics. The blocks $(10 * 15 * 3 \mathrm{~cm})$ are dry salted subsequently. 


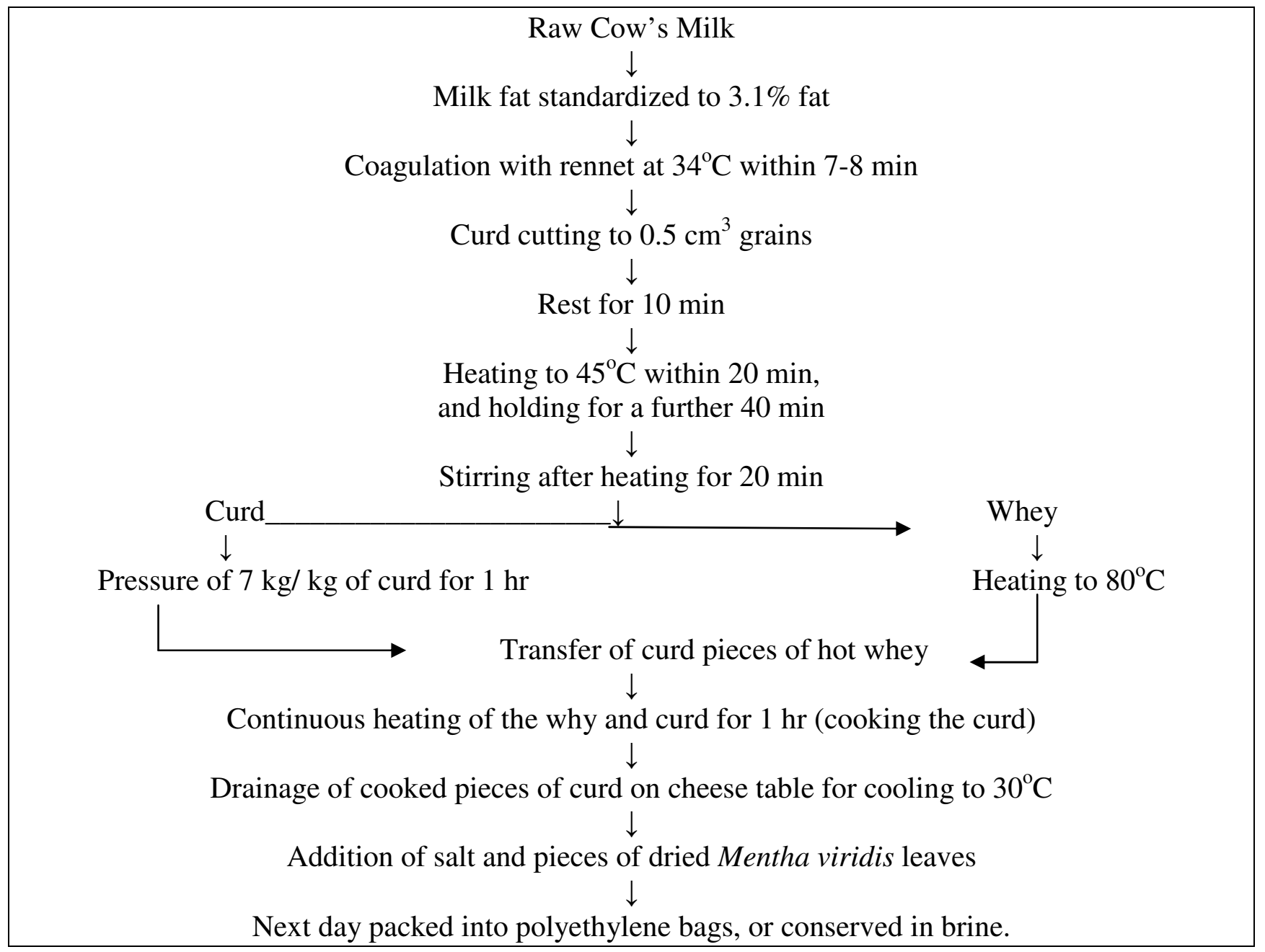

Figure 2.4 Process flow chart for industrial manufacture of Halloumi from cow milk

\subsubsection{Composition and Yield}

The yield of Halloumi is significantly dependent on the chemical composition of the milk used for production. It is $17.1 \%$ for ovine milk and $10.2 \%$ for caprine milk (Kaminarides et al., 2000). This is because total solid recovery was significantly higher in cheese made from ovine milk than in that made from caprine milk. Chemical composition of Halloumi (100 g) cheese made from sheep's milk and cow's milk is as per the table 2.4 . 
Table 2.4 Chemical Composition of Halloumi cheese (100 g) made from sheep's and cow's milks from Cyprus market (means of 13 and 15 replicates respectively)

(From Anifantakis and Kaminarides (1982, 1983))

\begin{tabular}{|l|c|c|c|c|}
\hline \multirow{2}{*}{ Component } & \multicolumn{2}{|l|}{ Sheep's Milk } & \multicolumn{2}{l|}{ Cow's milk } \\
\cline { 2 - 5 } & Mean & Standard Deviation & Mean & Standard Deviation \\
\hline Moisture & 42.15 & 1.39 & 42.88 & 0.85 \\
\hline Fat & 27.85 & 1.76 & 27.6 & 0.76 \\
\hline Fat-in-dry-matter & 48.09 & 1.95 & 48.32 & 0.95 \\
\hline Protein & 23.71 & 1.02 & 23.41 & 0.55 \\
\hline Protein-in-dry-matter & 41.02 & 2.37 & 40.98 & 0.88 \\
\hline $\mathrm{NaCl}$ & 1.44 & 0.28 & 1.56 & 0.34 \\
\hline $\mathrm{pH}$ & 5.86 & 0.22 & 6.3 & - \\
\hline
\end{tabular}

Severe heat treatment of curd blocks in whey along with high salt content reduces microbial count in the final cheese. Also, proteolysis is very limited as most of the rennet is deactivated during heat treatment in whey.

\subsubsection{Patents on flow restricted cheeses}

Several researchers have used various approaches to attain the objective of low or controlled flowing of cheese. Farkye and Lee (1998) under US patent number 5,766,657 used a method for controlling the degree of flowing of natural cheese by integrating in various proportions and pressing two curd types (Curd I and Curd II) to produce a cheese with restricted flow properties. Curd I was produced by acidification of heated milk and curd II was produced from rennetcoagulated milk inoculated with lactic acid bacteria. The ratios of curd I and curd II was ranging from 5:95 to $95: 5$ at temperature of $26^{\circ} \mathrm{C}\left(78^{\circ} \mathrm{F}\right)$ to $88^{\circ} \mathrm{C}\left(190^{\circ} \mathrm{F}\right)$. The time of integration was 2 min 
to 30 minutes. They demonstrated that the flow and flow value of a cheese product can be selected by varying the ratio of acid curd to rennet curd.

In another approach, Strandholm et al. (1989) subjected process cheese blend containing whey protein to heat treatment conditions such that a minimum of about $0.5 \%$ (wt. /wt. on wet basis) of cross-linked beta-lactoglobulin is provided in the process cheese mix. They suggested the heat treatment conditions to be a minimum of $82.2^{\circ} \mathrm{C}\left(180^{\circ} \mathrm{F}\right)$ for at least about 1 minute or $93.3^{\circ} \mathrm{C}$ $\left(200^{\circ} \mathrm{F}\right)$ for 0.5 minutes. The flow value for process cheese after such heating conditions were claimed to be in the range of 1 to 2 .

Schulz (1976) added coagulating protein such as albumin in the process cheese at the rate of 1 to $20 \%$. The coagulating protein coagulates at temperature above $70^{\circ} \mathrm{C}$. The coagulant was added to the process cheese after its manufacture when the temperature of the cheese has a temperature lower than $70^{\circ} \mathrm{C}$. Upon subsequent heating of the process cheese to temperatures above $70^{\circ} \mathrm{C}$, the protein coagulates thereby stiffening the process cheese and preventing it from flowing.

\subsubsection{Research work leading to the idea of HPDF}

Yeung (1997) investigated procedure of manufacturing high moisture cheese using combination of high heat and acid coagulation. The procedure of manufacturing was similar to ricotta approach as per section 2.2.2 with varying levels of whey/ milk mixtures. He investigated the effects of whey/milk blend at three different levels (90/10, 80/20 and 70/30) with three different acidification ranges (5.66-5.75, 5.76-5.85 and 5.86-5.95) on texture, composition and yield of cheese.

The moisture content of high moisture cheese was in the range of $68-72 \%$. It was concluded from the experiments that protein content increased in cheese when the casein content of whey/milk blend and acidification range increased. Also, all whey/milk blends had a lower whey protein and 
higher casein content with increase in acidification range. The highest yield was obtained for a 70/30 whey/ milk blend and a pH range of 5.66-5.75.

Highest peak force was correlated with lower acidification range meaning the cheese hardness increases with decrease in acidification range of the experiment. When texture of cheese was compared with tofu, the cheeses have texture ranging from soft to moderately firm texture.

\subsection{Chemical Interactions governing Heat induced partially acidified gel}

The goal of this project is to understand the effect of heating treatment and acidification of milk on the flowing quality of cheese. Therefore, it is very important to understand the modifications in the native milk constituents during heating and acidification of milk. Heating milk is essential step in manufacturing of most dairy products to extend shelf-life and improve its quality by number of living microorganisms. Therefore, it is of prime importance to understand the effect of heat treatment on various milk constituents and resultant effect of physicochemical properties of products, manufactured. One of the prime impacts of heat treatment on milk is on the formation of acid gels in the manufacture of products like yogurt and acid cheeses. Heat-treated milks have shorter gelation time and gelation occurs at higher $\mathrm{pH}$ values than in unheated milk. In addition acid gels made from heated milk have an increased firmness and strength compared to gels from unheated milk (Lucey et al., 1998).

\subsubsection{Heat induced denaturation of whey protein and its association with Casein micelles}

When milk is heated at temperatures $>70^{\circ} \mathrm{C}$, major globular whey proteins like $\beta$-lactogloulin $(\beta$-lg) and $\alpha$-lactalbumin ( $\alpha$-la) are denatured. This temperature induced conformational change results in

exposure of reactive thiol groups. The extent of denaturation is affected by $\mathrm{Ca}^{2+}$, lactose, casein and whey protein concentration and $\mathrm{pH}$ (Law and Leaver, 1999). Heat denaturation of $\beta$-lg and its interaction with casein micelles through thiol group- disulfide bridge reaction has been widely 
studied and has always been area of interest (Dannenberg and Kesssler, 1988). At high temperatures, the free thiol group (-SH group in cysteine) in the globular protein becomes exposed and it reacts with one of -S-S- groups often of another molecule, whereby both molecules become bonded and forms a dimmer. Zittle et al. (1962), provided evidence that a heat-induced interaction between $\beta$-lg and $\kappa$-casein occurred. He used purified protein solutions and showed that unheated solutions of $\kappa$ casein and $\beta-\lg$ formed discrete bands and on heating, a species of intermediate mobility was formed under electrophoretic conditions. This was later confirmed by numerous other studies (Noh and Richardson, 1989; Jang and Swaisgood, 1990). It has also been demonstrated that $\alpha$-la also participate in the reaction with $\kappa$-casein (Law et al., 1994). Table 2.5 indicates denaturation of $\alpha$-la and $\beta$-lg at various heating conditions. (Fox, 1981)

Table 2.5 Proportion of $\beta$-lactoglobulin and $\alpha$-lactalbumin complexed with casein micelles at various heat treatments (measurements were made on slimmed milk)

\begin{tabular}{|l|l|l|}
\hline Heat Treatment & $\% \beta$-lg & $\% \alpha$-la \\
\hline $70^{\circ} \mathrm{C}$ for $45 \mathrm{~min}$ & 2 & 0.3 \\
\hline $95^{\circ} \mathrm{C}$ for $0.5 \min$ & 58 & 8 \\
\hline $95^{\circ} \mathrm{C}$ for $20 \mathrm{~min}$ & 85 & 55 \\
\hline $140^{\circ} \mathrm{C}$ for $2 \mathrm{sec}$ & 43 & 9 \\
\hline $140^{\circ} \mathrm{C}$ for $4 \mathrm{sec}$ & 54 & 12 \\
\hline
\end{tabular}

The degree of denaturation of $\alpha$-la (which on its own denatures semi-reversibly) increases due to thiol group-disulfide bridge exchange reaction when $\beta$-lg is present (Elfagm and Wheelock, 1977). However, not all $\beta$-lg and $\alpha$-la is bound to the casein. A considerable fraction forms soluble whey protein aggregates (Oldfield, Singh and Taylor, 1998, there are also soluble complexes containing mainly $\kappa$-casein and the whey proteins (Vasbiner and Kruif, 2003). The partition of material between soluble and miceller complexes has been shown to depend on $\mathrm{pH}$ at which milk is 
heated. Denatured whey proteins appear to bind more to the casein micelles at low $\mathrm{pH}$ (around 6.5), whereas more soluble complexes are formed if the milk is heated at a $\mathrm{pH}$ great than that of the native milk (Anema and $\mathrm{Li}, 2003$ ). Temperature of heating and $\mathrm{pH}$ are two most important factors. Temperature determines the rate and extent of denaturation and $\mathrm{pH}$ governs the interaction with the casein micelles.

\subsubsection{Aggregation of casein micelles}

Native casein micelles in normal milk are stabilized by a negative charge and a steric repulsion. When milk is acidified, casein micelles aggregates due to neutralization of negative charges, as a result a three dimensional network is formed (Walstra, 1990).

Heat treatment upto $90^{\circ} \mathrm{C}$ has little effect on casein micelle size, but when at higher temperature, there is an increase in casein micelle size and decrease in the range of micelle size (Mohammad and Fox, 1987). Casein micelles, which constitute roughly $80 \%$ of the protein in bovine milk, comprise four types of caseins $\left(\alpha_{\mathrm{s} 1}, \alpha_{\mathrm{s} 2}, \beta\right.$ and $\left.\kappa-\mathrm{CN}\right)$ in combination with appreciable quantities of micellar or colloidal calcium phosphate (CCP). Earlier, it was assumed that submicelles are held together in the micelles by bridges of CCP (Schmidt, 1982) but later it was proved that a number of factors are responsible for integrity of casein micelles. $\mathrm{Ca}^{2+}$ also play important role in the integrity of the micelle. $\alpha_{\mathrm{s} 1}, \alpha_{\mathrm{s} 2}, \beta-\mathrm{CN}$ are very sensitive to calcium induced precipitation at calcium concentration greater than $5 \mathrm{mM}$ but since they exist in colloidal dispersion surrounded by $\kappa$ $\mathrm{CN}$ (which is not calcium sensitive) in casein micelles, the caseins are stable at calcium concentration present in milk, i.e. $\sim 300 \mathrm{mM}$. (Singh and Fox, 1985). $\kappa-\mathrm{CN}$ is very prone to heat induced aggregation, due to the presence of two cysteine residues in its structure as addition of $\beta$ mercaptoethanol or other reducing agent modifies the structure and inhibits coagulation (Fox, 1981). 


\subsubsection{Changes during Acidification of Milk}

When milk is acidified by bacterial culture, direct addition of acids or by use of glucono- $\delta$-lectone (GDL), many of the physico-chemical properties of casein micelles go through a considerable change especially in the $\mathrm{pH}$ range of 5.0-5.5. As the $\mathrm{pH}$ of milk is reduced, $\mathrm{CCP}$ is dissolved (Pyne and McGann, 1960) progressively. Its solubilization completely at pH 5.0 dissociates micelles. However, the extent of dissociation depends upon the temperature. At $30^{\circ} \mathrm{C}$, a decrease in $\mathrm{pH}$ causes virtually no dissociation, but at $4{ }^{\circ} \mathrm{C},>40 \%$ of caseins are dissociated at $\mathrm{pH} 5.5$ (Dalgleish and Law, 1988). Temperature of acidification had no effect on solubilization of CCP. At a $\mathrm{pH} \sim 5.1$, most of the $\mathrm{CCP}$ in the micelles has been solubilized, the charge of the individual caseins has been altered and the ionic strength of the solution increased. As a result, the forces responsible for the integrity of the "micelle-like" structure collapses and casein particles aggregates leading to formation of chains and clusters that are linked together to form a three-dimensional gel network(Mulvihill and Grufferty, 1995).

The gels made from acidified heated milk are significantly different from that of made from acidified unheated milk in terms of microstructure. There are more branching and interconnectivity in the gel network in heated milk gels than in unheated milk gels (Lucey et al., 1998). The presence of denatured whey protein on the surface of casein micelles may hinder the close proximity of other casein micelles and reduce the likelihood that dense clusters of casein micelles could be formed. The denatured whey proteins attached to casein micelles may cross link. This is different from acidified unheated milk gel in which the casein micelles are held together by hydrophobic bonds or charged residues. This difference in microstructure is primarily responsible for different mechanical properties of acid gels, produced from unheated or heated milk. 
Thus, in the heat induced partially acidified gel system, denaturation of whey protein (particularly $\beta-\lg$ ) and its cross-linking with casein micelle (particularly $\kappa-\mathrm{CN}$ ) is an important reaction. Such cross-linking acts to restrict the mobility of the protein upon being subjected to heating and, hence, acts to restrict the flowing of the final product (Strandholm et al., 1989).

To evaluate the effect of processing parameters on newly developed high protein food texture and flowing quality, understanding of various methods of texture and flowing measurement in the scientific research. An overview of commonly used texture and flowing measurement techniques is provided in section 2.4

\subsection{Analysis of cheese texture and flow}

Texture is one of the important factors in evaluation of food quality. Numerous studies have confirmed that texture affects the consumer perception of quality as well as acceptability (Muir et al., 1997). Sensory evaluation of cheese texture evaluation requires extensive training and therefore, time consuming. In addition, the wide variation in the test results can affect the conclusion. As a result instrumental methods were developed to correlate with sensory evaluation of texture. The instrumental methods can be grouped under three categories (Scott-Blair, 1958): empirical, imitative and fundamental. On the other hand, Szczesniak (1963) classified the textural properties of food in three categories: mechanical, geometrical and other. The mechanical properties were further grouped as primary (which can be measured directly by instrument e.g. hardness, cohesiveness, viscosity, adhesiveness) and secondary (which can be derived from primary e.g. chewiness and gumminess). The geometrical properties are related to sample size and shape and other properties are related to composition of food. This classification was intended to be used with both sensory and instrumental measurements of texture in order to bridge the gap between both forms of texture measurement. Many empirical and imitative instrumental tests have been developed to correlate with sensory 
texture descriptors but by far the most popular imitative test has been the texture profile analysis (Szczeniak, 1963; Bourne, 1978).

\subsubsection{Texture Profile Analysis}

This method was originally developed at the General Foods Corporation Technical Center in the early 1960s (Friedman et al., 1963). It is essentially a uniaxial compression test except the fact that a) In TPA test, the sample is subjected to a two-step compression. The first compression step is called "first bite" and is followed by a second compression, the "second bite". The two bites simulate biting action of human jaws.

b) Deformation used in TPA test is often $70 \%$ or more.

A typical TPA test would generate force-time profile as per figure 2.5

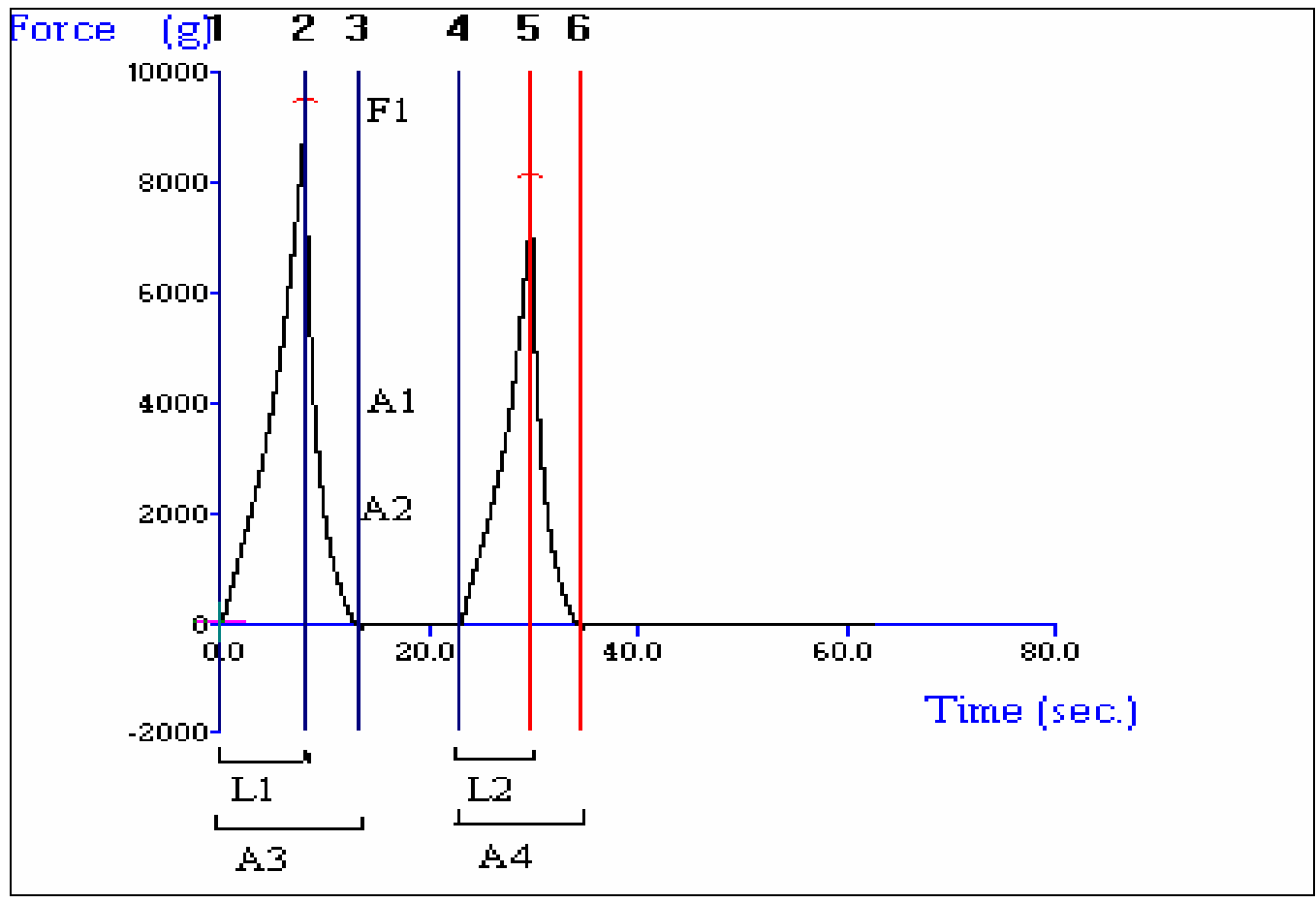

Figure 2.5 Texture Profile Analysis of cheese 
The many textural properties determined from TPA curve are: hardness, cohesiveness, adhesiveness, gumminess and springiness. These terms are defined in the Table 2.6 along with appropriate dimensions and SI units for each term. In the figure, A represents Area under the curve and $\mathrm{L}$ represents length on $\mathrm{X}$-axis.

Table 2.6 TPA texture terms and definition (Friendman (1963), Bourne (1968), Szczesniak (1963))

\begin{tabular}{|l|l|l|l|}
\hline TPA term & Definition & How to measure & SI unit \\
\hline Hardness & $\begin{array}{l}\text { Force necessary to attain a given } \\
\text { deformation }\end{array}$ & $\begin{array}{l}\text { Force corresponding to } \\
\mathrm{F}_{1}\end{array}$ & $\mathrm{~N}$ \\
\hline Cohesiveness & $\begin{array}{l}\text { Strength of the internal bonds making up the } \\
\text { body of the product }\end{array}$ & $\mathrm{A}_{4} / \mathrm{A}_{3}$ & - \\
\hline Gumminess & $\begin{array}{l}\text { Energy needed to disintegrate a semisolid } \\
\text { food until it is ready for swallowing }\end{array}$ & Hardness ${ }^{*}$ cohesiveness & $\mathrm{N}$ \\
\hline Springiness & $\begin{array}{l}\text { Distance recovered by the sample during the } \\
\text { time between end of first bite and start of } \\
\text { second bite }\end{array}$ & $\mathrm{L}_{2}$ & $\mathrm{M}$ \\
\hline Chewiness & $\begin{array}{l}\text { Energy need to chew a solid food until it is } \\
\text { ready for swallowing }\end{array}$ & $\begin{array}{l}\text { Hardness }{ }^{*} \text { cohesiveness } \\
{ }^{*} \text { Springiness }\end{array}$ & $\mathrm{J}$ \\
\hline
\end{tabular}

\subsubsection{TPA testing of cheese}

The first TPA test was performed using the General Foods Texturometer (GFT) that compressed the sample in two successive deformations by means of a flat plunger. To imitate grinding action of the jaw, the plunger was driven by an eccentric at constant sinusoidally varying speed, coming to a momentary stop at both ends of the stroke. In the modern day research, TPA test of cheese is performed under Texture Analyzer shown in Figure 2.6. The analyzer is hooked up with a computer on which one can set test conditions such as pre-test speed, test speed, post-test speed and compression. The computer will generate Force vs. time profile as shown in Figure 2.5. 


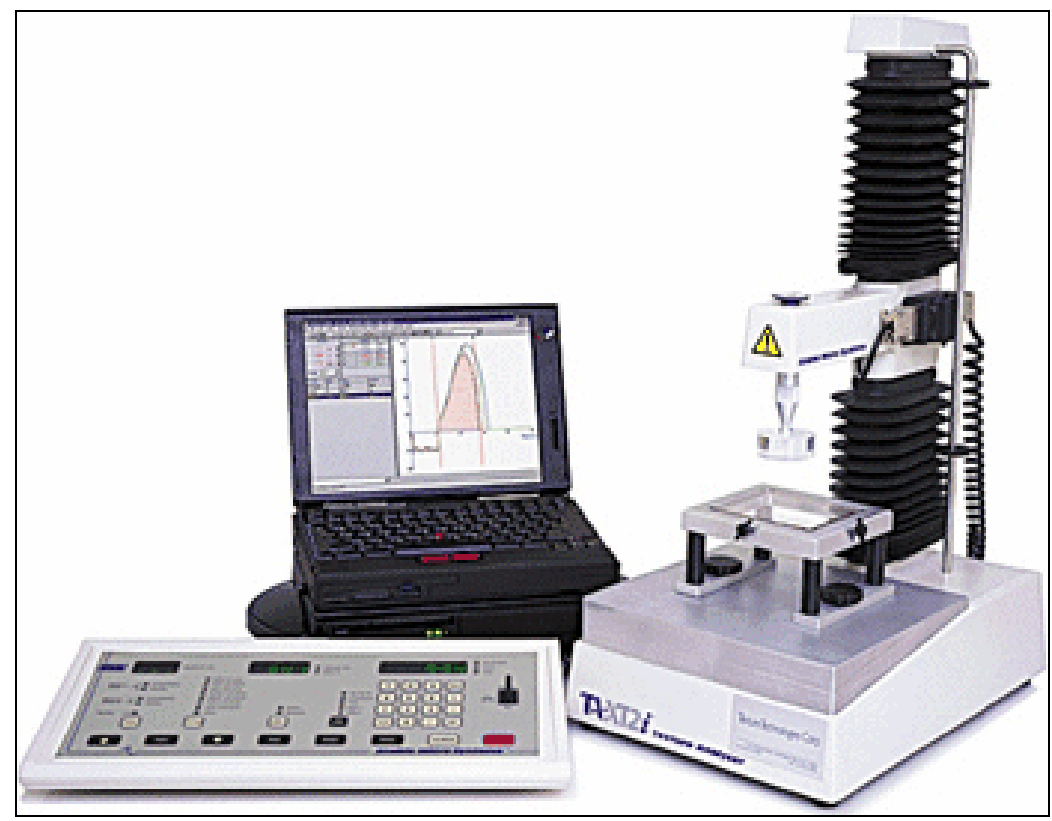

Figure 2.6 TA-XT2 Texture Analyzer.

The test results of a typical TPA test will be affected by rate of compression as well as time between the first and second bite. This factor is not accounted in the typical TPA test. For optimal correlation with sensory data, each type of cheese may have to be tested instrumentally under different conditions. However, in typical TPA test, the cheese is compressed $50 \%$ or more of the sample height.

The firmness of cheese sample is not affected by compression ratio (20 to 80\%) (Imoto et al., 1979). However the variation in TPA data due to the extent of deformation can be fixed by standardization of the test protocol (Bourne and Comstock, 1981). Also, the deformation rates used during a TPA test are selected empirically. The deformation rate in the mouth during chewing is estimated to be between 1400 to $1500 \mathrm{~mm} / \mathrm{min}$ (Langley and Marshall, 1993) and that between fingers during squeezing is $150 \mathrm{~mm} / \mathrm{min}$. (Voisey and Crete, 1973). The TPA test strain rate should match this data of human consumption of food. In addition, acceptable ranges of test parameters and sample geometry should be defined for cheese in order to obtain and compare TPA data from different laboratories. 
There are some researchers who tried to correlate the TPA data with functional properties of cheese such as flowability. A positive correlation was found between process Cheddar cheese flowability (at $139^{\circ} \mathrm{C}$ ) and TPA cohesiveness. (Harvey et al., 1982). However, Gupta et al. (1984) observe such a correlation between cohesiveness and melatability $\left(\right.$ at $\left.92^{\circ} \mathrm{C}\right)$. These discrepancies and correlations can be attributed to the TPA test protocol used and the flowability measurements they made. Therefore, it is essential to standardize the protocol of TPA measurement while comparing functional properties of different cheeses.

\subsubsection{Measuring cheese flow properties}

The objective definition of flowability of cheese is "the ease and extent to which cheese will flow and spread upon heating". A good flowability method should accommodate two aspects: (a) rate of heat transfer in solid cheese (b) thermal phase change in solid cheese (Park et al., 1984).

Many empirical tests are available to compare the melatability of cheeses. Arnott et al. (1957) used a method in which the percentage decrease in cylinder height of cheese sample before and after heat treatment was used as a mean to compare flowing behavior of different cheeses. Olson and Price (1958) reported two problems in this method: (a) film formation on the surface due to exposure to air during heating (b) uneven flowing of flowed cheese. They proposed a new method which is also known as "tube method". A glass tube, closed on the one end with a rubber stopper, holds a measured quantity of sample. A reference line is drawn on the surface of the tube to mark the point before heat treatment. The cheese sample is first tempered for $30 \mathrm{~min}$ at $4.4^{\circ} \mathrm{C}$ and then heated in an oven at $110^{\circ} \mathrm{C}$ for $6 \mathrm{~min}$ in horizontal position. The tube is tilted at around $45^{\circ}$ to facilitate free flow. The distance of flow from the reference line is measured. The tube is reheated for an additional 2 min in horizontal position, and the distance of flow is measured again. The total distance (in mm) 
covered by cheese sample in $6+2$ min is called "cheese flow". The two stage heating employed will take car of film formation and dried surface during uncovered heating of cheese in open air.

The most popular method used in the industry is called "Schreiber flow test", .designed for mozzarella and processed cheese and proposed by Kosikowski (1977). A typical test is as per Figure 2.7. The method describes heating the cheese sample with $41 \mathrm{~mm}$ diameter and $0.5 \mathrm{~cm}$ thickness on a thin-walled $15^{*} 100 \mathrm{~mm}$ glass dish at $232^{\circ} \mathrm{C}\left(450^{\circ} \mathrm{F}\right)$ for exactly $5 \mathrm{~min}$. After $30 \mathrm{~min}$, the outer edge of flow line of cheese is recorded numerically. The higher the number, the more is the flowing quality of cheese. The test is very popular because of its ease of sample preparation, execution of test and ease of comparison of the test results.

However, some of short coming of this test are (a) excessive and uncontrolled heat treatment without taking into account evaporative cooling and moisture loss of some of the cheeses (b) error in measurement of flow line especially for the cheese that does not spread evenly upon heating e.g. low fat cheese.

To overcome this problem, Muthukumarappan et al. (1999) proposed some modification in the Schreiber flow test. They measured both the cheese flow line per traditional test as well as cheese spread area. Based on the investigation, they proposed that the test for Mozzarella should be performed at $90^{\circ} \mathrm{C}$ for $5 \mathrm{~min}$ of an aluminum plate and the flowed spread area should be measure to quantify the flowing quality. Bogenrief and Olson (1995) used microwave heating for 45 seconds in stead of traditional convection oven. Park et al. (1984) found marked lack of correlation between the Schreiber and Arnott test when they performed both the tests in convection and microwave oven. 

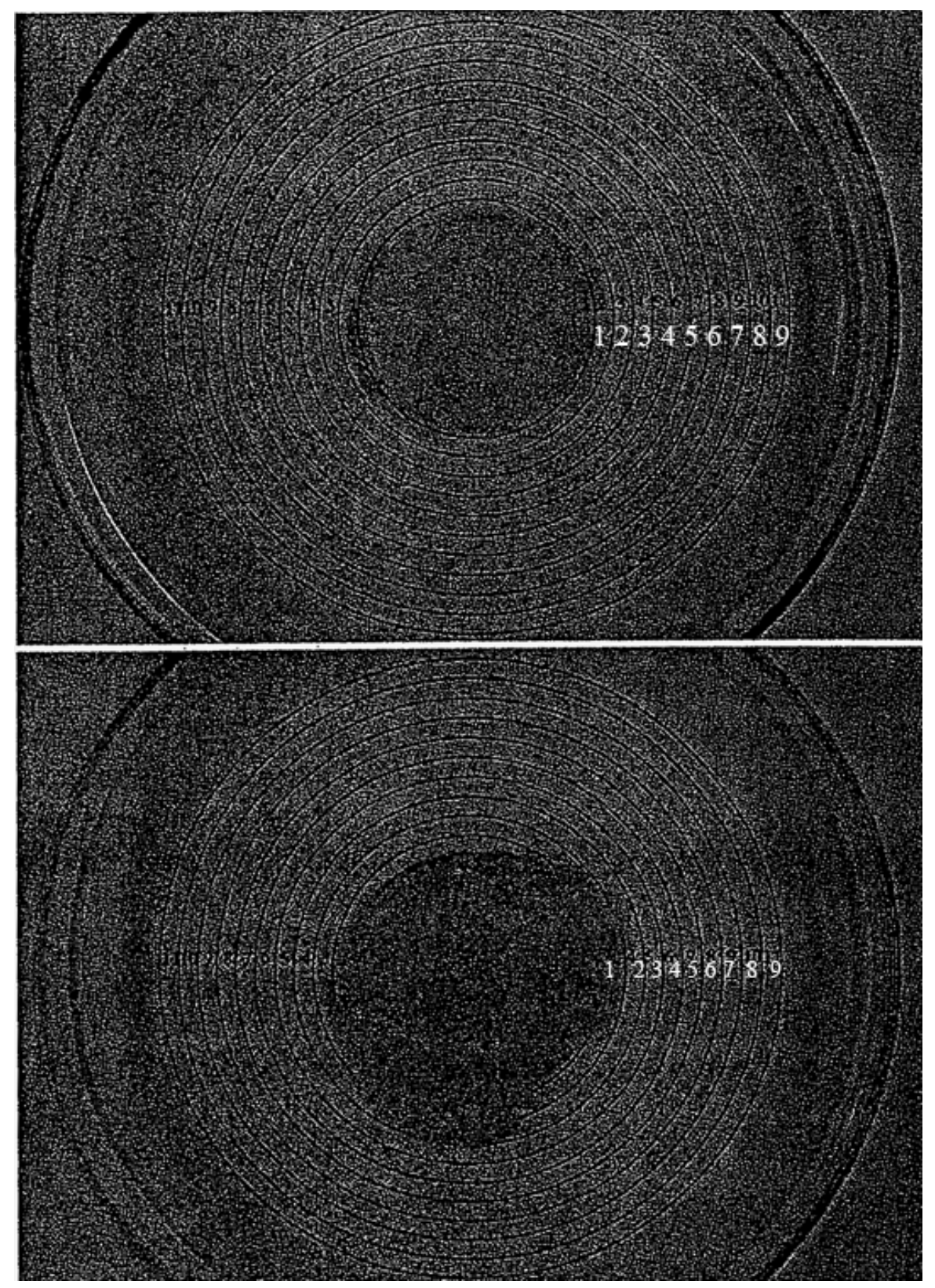

Figure 2.7 Schreiber test- cylindrical sample of cheese (top) placed on a Petri dish and heated in oven (bottom_ for measuring increase in diameter of spread. A grid of numbered concentric circles is laid for measurement.

They further commented that in any evaluation of cheese melatability, the rheological and thermal aspects should be considered and that both the Schreiber and Arnott tests do not measure the same rheological attributes. 
Wang and Sun (2001) used computer-vision system to measure cheese spread area. They used the flowing degree (flowing before and after heating) and flowing rate (rate of change in flow area during the first minute of heating). Gunasekaran et al. (2002) described some modification in the Schreiber test protocol. They replaced the convective oven by direct conduction heating via the metal plate on which the cheese disk is heated and allowed to flow. This type of heating is faster and allows continuous monitoring of cheese flow/flow measurement. This method is also useful for multiple sample measurement.

In addition to these empirical tests, numerous researchers have worked on measurement of flowability objectively by characterizing the fundamental rheological properties using dynamic rheometer. Measurement of cheese viscosity was the principle in objectively quantifying flowability. Ease of flow under applied stress is viscosity (stress to strain rate) which can help estimate the flowability. Some of the examples of measuring cheese flow objectively are steady shear viscometry, capillary rheometry, and squeeze-flow rheometry.

Thus, evaluation of cheese flow profile has been area of interest for researchers. Various preliminary and advanced tests have been used to quantify and evaluate cheese flow. 


\subsection{Objectives with Hypothesis}

From the literature review, it is clear that all the approaches to restrict flow property are dependent upon processing parameters. Therefore, the overall objectives of this study were in three phases:

\subsection{Phase 1}

The first phase was designed to investigate the effect of pasteurization condition, homogenization condition and $\mathrm{pH}$ of acidification on the flowing, textural and compositional properties of HPDF.

\subsubsection{Experimental design 1}

a. Milk pasteurization conditions affect the flowing, textural and compositional properties of HPDF.

b. Homogenization affects the flowing, textural and compositional properties of HPDF.

c. $\mathrm{pH}$ of acidification of milk affects the flowing, textural and compositional properties of HPDF.

\subsubsection{Experimental design 2}

a. Milk pasteurization conditions affect the flowing, textural and compositional properties of HPDF.

b. $\mathrm{pH}$ of acidification of milk affects the flowing, textural and compositional properties of HPDF.

\subsubsection{Experimental design 3}

a. Homogenization affects the flowing, textural and compositional properties of HPDF.

\subsection{Phase 2}

The second phase was designed to evaluate the HPDF as tofu alternative by incorporating in various tofu recipes and get consumer feedback.

\subsection{Phase 3}

The third phase was designed to compare the textural properties of HPDF with that of commercial tofu. 


\subsection{MATERIALS AND METHODS}

The initial trials consisted of narrowing down to one approach out of many approaches available to achieve the desired non-flowing characteristics. For each trial, $10 \mathrm{~kg}(22.05 \mathrm{lbs}) 1 \%$ fat milk was converted to manufacture high protein dairy food (HPDF) using Paneer, Ricotta and Halloumi approach as discussed in sections 2.2.1, 2.2.2 and 2.2.3. Visual observation of microstructure and analysis of flow properties under oven, microwave and hot water (as described in section 4.5.3) were carried out on final HPDF. As expected, all three approaches produced food with no flowing under the conditions described. Next, the macrostructure (by means of visual observation) of the food was examined and the observations were compared with the available literature. In case of halloumi approach, curd from acid coagulated and rennet-treated milk consisted of distinguishable casein particles fused together in chains and clusters (Figure 4.1). The structure of curd from acid coagulated milk shows relatively large protein particles composed of transformed and indistinguishable casein particles (Figure 4.2) (Kalab and Modler, 1985).

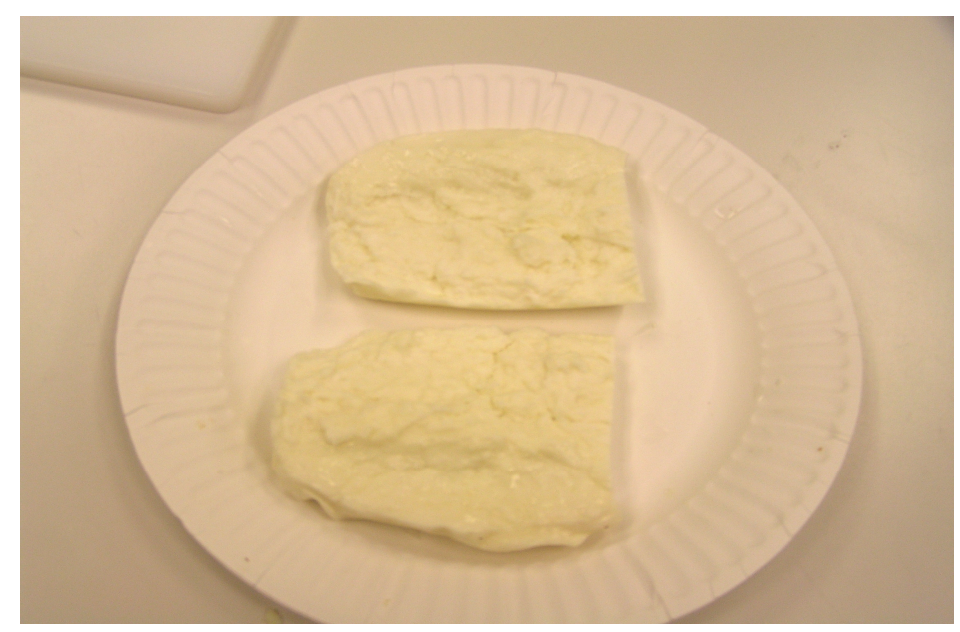

Figure 4.1.Structure of HPDF made by Hallumi Approach 


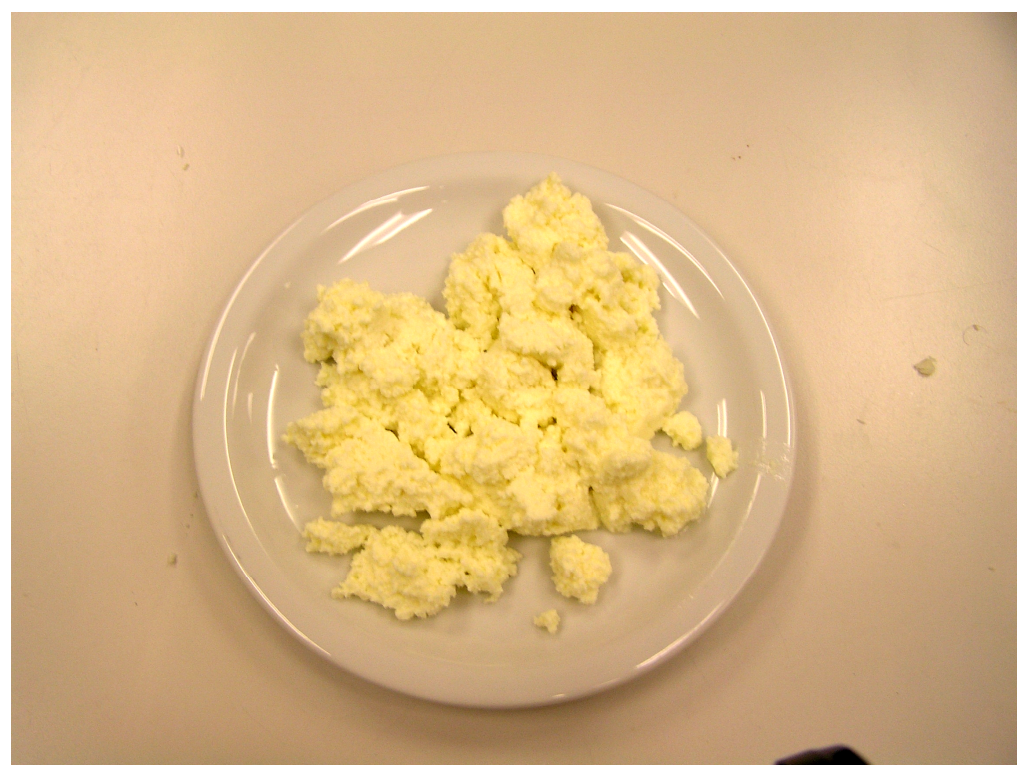

Figure 4.2.Structure of HPDF made by Paneer/Queso Blanco approach

One of the objectives of this project was to develop meat-like texture in tofu alternative high protein food. The structure obtained by halloumi approach had potential to achieve this objective unlike paneer/queso blanco or ricotta approach. Moreover, one of the variables in the hypothesis was $\mathrm{pH}$ of acidification of milk. Adjustment of $\mathrm{pH}$ was more likely in case of acid-coagulated rennettreated milk (halloumi approach) than just acid-coagulated milk. (paneer/queso blanco approach). Considering these factors, halloumi approach was more suitable for the manufacture of high protein dairy based food. 


\subsection{Milk for making HPDF}

Fresh raw milk 68-76 liters(18-20 gallons) was picked up from Cal Poly dairy farm located at California Polytechnic State University, San Luis Obispo. Cal Poly dairy herd has both Holstein and Jersey cows. In order to standardize milk composition, fresh pasteurized skim milk in 23 liters (6 gallon) bags were obtained from campus dining services at Cal Poly. Percent fat in raw milk was determined and skim milk was added to standardize the milk to 1 percent fat in final mixture. The entire task of determining percent fat in raw milk and standardizing it with skim milk is finished within one hour of milk pick up. The standardized milk was again tested for percent fat and then pasteurized with universal pilot plant (PMS Processing Machinery \& Supply Co.). The method of pasteurization was HTST (High Temperature Short Time) and the temperature was $71.6^{\circ} \mathrm{C}\left(161^{\circ} \mathrm{F}\right)$ for low, $79.4^{\circ} \mathrm{C}\left(175^{\circ} \mathrm{F}\right)$ for medium and $88.3^{\circ} \mathrm{C}\left(191^{\circ} \mathrm{F}\right)$ for high pasteurization temperature, as stated in the experimental design. The holding time for all the pasteurization temperatures was 16 seconds.

In experimental design 1 and 3 , where homogenization is one of the variables, the standardized milk is pasteurized and homogenized in UHT processing system. The homogenizer is Niro Soavi homogenizer. The first stage homogenization pressure employed was 2000 psi (13.8 $\mathrm{MPa})$ and that of second stage was $500 \mathrm{psi}(3.5 \mathrm{MPa})$.

All the processing is finished within 3 hours and processed milk is collected in previously cleaned stainless steel cans and stored in the milk cold store. The milk is utilized in making of HPDF within next 2-3 days. 


\subsection{Experimental Design}

This project was comprised of three experimental designs (as per sections 4.2.1, 4.2.2 and 4.2.3) in order to meet the objectives of the project. Data was collected and analyzed after each experimental design. The lower pasteurization condition was set according to the Pasteurized Milk Ordinance (PMO) of US Public Health standard pasteurization requirement for raw milk at $71.6^{\circ} \mathrm{C}$ $\left(161^{\circ} \mathrm{F}\right)$ for 16 seconds. The higher pasteurization temperature $88.3^{\circ} \mathrm{C}\left(191^{\circ} \mathrm{F}\right)$ for 16 seconds was set after reviewing various studies that evaluated effect of casein-whey protein interaction on the texture of heated acidified milk gel.(Vasbinder et al.,2003). Also, preliminary trials involving manufacture of HPDF pointed out wide range of difference particularly in flow properties (section 5.1), hence these pasteurization conditions were chosen to be two extremes.

The homogenization pressures were set as per the common industrial practice of homogenization of milk for cheese making at first stage $2000 \mathrm{psi}(13.8 \mathrm{MPa})$ and $500 \mathrm{psi}(3.5 \mathrm{Mpa})$ for second stage. Also, the high level of acidification was chosen on native $\mathrm{pH}$ of milk (6.6) to evaluate the effect of processing parameters without acidification and low level of acidification (5.8) was chosen on $\mathrm{pH}$ of coagulation to obtain the meat like stretch in pasta filata kind of cheese. The medium level of acidification (6.2) was set based on the average of these two levels of acidification.

\section{2.1 Heat treatment, Homogenization and Acidification Effect}

A randomized $2 \mathrm{X} 3 \mathrm{X} 3$ factorial experimental design was utilized with factor one as homogenization, factor two as pasteurization temperature and factor three as $\mathrm{pH}$ of acidification. The total 18 batches of HPDF making was finished roughly in one month period. Two batches of food comprises of two treatments, chosen in random order, were run on a day. It took 9 days in total to finish the manufacture of foods with one day of processing of milk in between two days. Within a week of manufacture, a sample from each of these batches of HPDF was drawn, and analyzed for 
chemical composition, textural and flowing qualities (as per section 4.5). A diagram of the design is depicted in table 4.1. Figure 4.3 is the flow chart for the experimental design.

Based on the results of experimental design 1, it was clear that low level of pasteurization temperature $\left(161^{\circ} \mathrm{F}\right)$ and high level of pasteurization $\left(191^{\circ} \mathrm{F}\right)$ had very significant effect on texture as well as flowing quality of HPDF. Hence, to study these effects in detail, a second experimental design was developed to possible effects of these treatments in duplicate. The effect of homogenization was studied in third experimental design with duplicate.

Table 4.1 Experimental design 1 factor and response variable

\begin{tabular}{|l|l|l|}
\hline \multicolumn{3}{|l|}{ Experimental Design 1} \\
\hline Pasteurization, Homogenization and Acidification Effect \\
\hline Factor & Treatment Levels & Response \\
\hline Homogenization & Yes & \\
\cline { 2 - 2 } & No & Analysis of Chemical, \\
& $\begin{array}{l}\text { Textural and Flowing } \\
\text { Properties of HPDF }\end{array}$ \\
\hline \multirow{3}{*}{ Pasteurization } & $161^{\circ} \mathrm{F}$ for $16 \mathrm{sec}$ & \\
\cline { 2 - 2 } & $175^{\circ} \mathrm{F}$ for $16 \mathrm{sec}$ & \\
\cline { 2 - 2 } & $191^{\circ} \mathrm{F}$ for $16 \mathrm{sec}$ & \\
\hline \multirow{3}{*}{$\mathrm{pH}$ of acidification } & 5.8 & \\
\cline { 2 - 2 } & 6.2 & \\
\cline { 2 - 2 } & 6.6 & \\
\hline
\end{tabular}




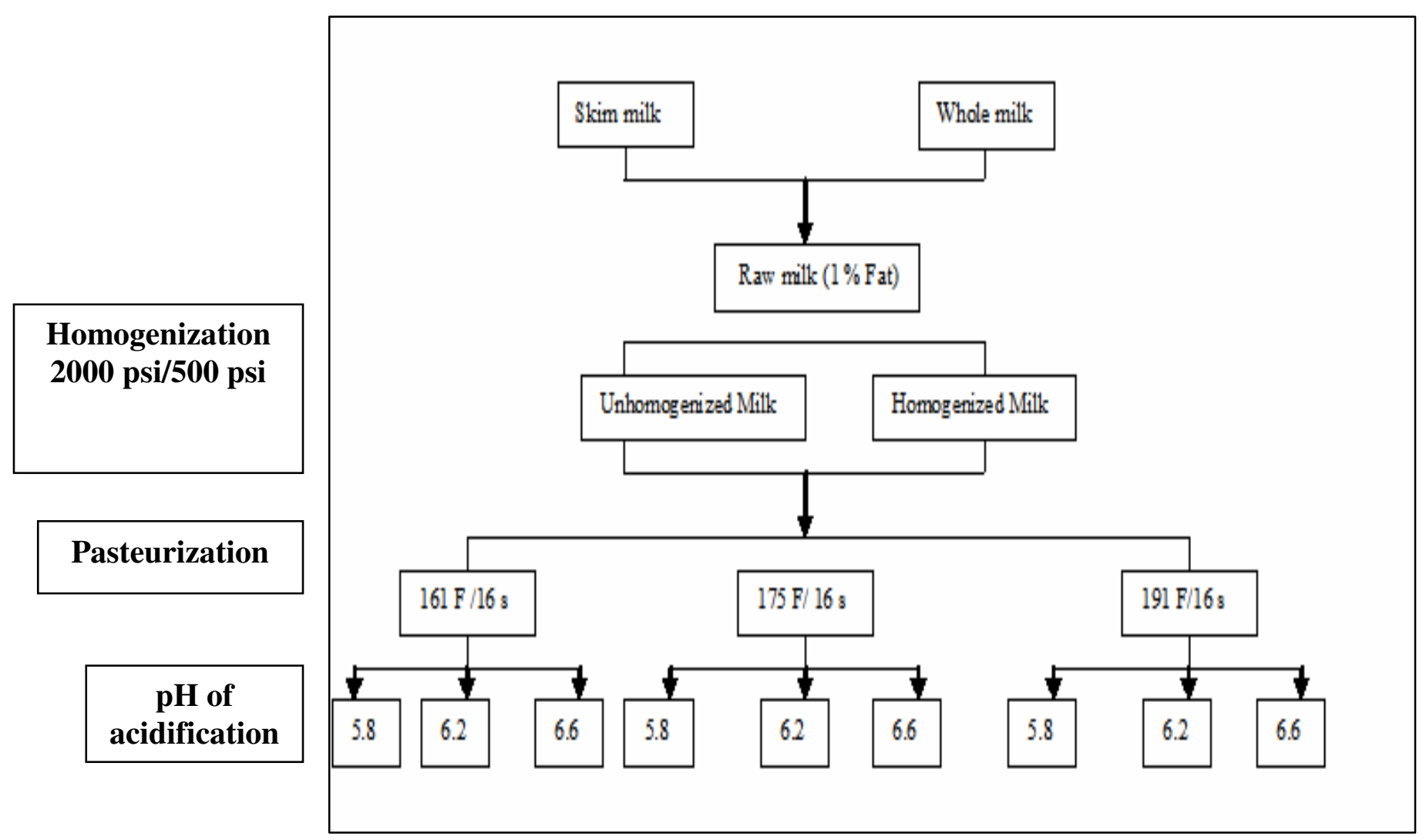

Figure 4.3.Flow chart for experiment design 1: effect of heat treatment, homogenization and acidification on chemical, textural and flowing quality of HPDF

\subsubsection{Heat Treatment and Acidification effect}

Experimental design 2 consisted of a more focused approach. The aim was to evaluate the effects of pasteurization and acidification on properties of HPDF by running the experiment in duplicate and hence to confirm the results obtained in previous stage as well as increase the power of experiment. The experiment design comprised of a randomized factorial design $2 \mathrm{X} 3$ with replicates with high pasteurization temperature $\left(191^{\circ} \mathrm{F}\right)$ and low pasteurization temperature $\left(161^{\circ} \mathrm{F}\right)$ as pasteurization treatment levels. Also, the acidification treatments involved low $\mathrm{pH}$ at 5.8, medium $\mathrm{pH}$ at 6.2 and high $\mathrm{pH}$ at 6.3. It took 6 days to finish the manufacture of foods with one day of processing of milk in between two days. A diagram of the design is as per table 4.2. The flow chart for experimental design is as per figure 4.4 
Table 4.2 Experimental design 2 factor and response Variables

\begin{tabular}{|l|l|l|}
\hline Experimental Design 2 \\
\hline Heat Treatment and Acidification Effect \\
\hline \multirow{3}{*}{ Factor } & $\begin{array}{l}\text { Treatment } \\
\text { Levels }\end{array}$ & \multirow{2}{*}{ Response } \\
\hline Pasteurization & $161^{\circ} \mathrm{F}$ for $16 \mathrm{sec}$ & \\
\cline { 2 - 2 } & $191^{\circ} \mathrm{F}$ for $16 \mathrm{sec}$ & \multirow{2}{*}{$\begin{array}{l}\text { Analysis of Chemical, } \\
\text { Textural and flowing } \\
\text { properties of HPDF }\end{array}$} \\
\cline { 1 - 2 } $\mathrm{pH}$ of acidification & 5.8 & \\
\cline { 2 - 3 } & 6.2 & \\
\cline { 2 - 3 } & 6.6 & \\
\hline
\end{tabular}

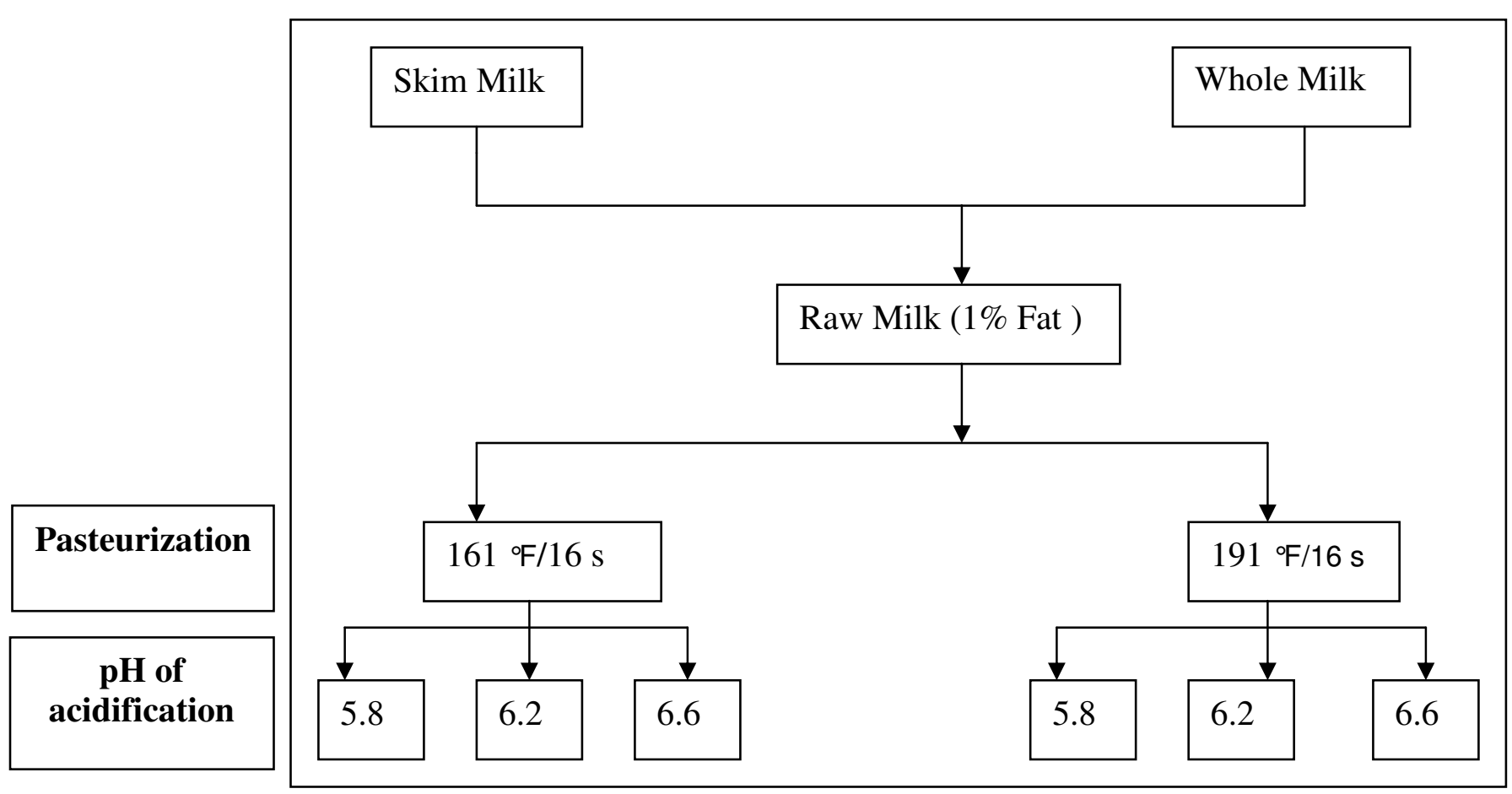

Figure 4.4.Flow chart for experimental design 2: effect of heat treatment and acidification on compositional, textural and flowing quality of HPDF.

Within a week, a sample from each of these batches of HPDF was drawn, and analyzed for chemical composition, textural and flowing qualities (as per section 4.5).

\subsubsection{Homogenization Effects}

The last experimental design was focused on study of homogenization on properties of HPDF. A randomized 2X2 factorial design was employed with homogenization as the only factor. The pasteurization temperature was $191^{\circ} \mathrm{F}$ for 16 seconds and the $\mathrm{pH}$ of coagulation was 5.8. The 
homogenization pressure was 2000psi (13.8 MPa) for first stage and 500 psi (3.8 MPa) for second stage. The experiment was replicated once. The milk was processed in one day and the 4 batches were manufactured within 2 days. Figure 4.5 indicates the design of experiment. Again, samples were drawn randomly from each batch and analyzed for compositional, flowing and flow properties as per section 4.5 .

Table 4.3.Experimental Design 3 Factor and Response Variables

\begin{tabular}{|c|c|c|}
\hline \multicolumn{3}{|c|}{ Experimental Design 3} \\
\hline Factor & $\begin{array}{l}\text { Treatment } \\
\text { Levels }\end{array}$ & Response \\
\hline \multirow{3}{*}{$\begin{array}{l}\text { Homogenization } \\
2000 \mathrm{psi}(13.8 \mathrm{MPa}) \\
\text { first stage and } 500 \mathrm{psi} \\
(3.8 \mathrm{MPa}) \text { second stage }\end{array}$} & Yes & \multirow{3}{*}{$\begin{array}{l}\text { Analysis of Compositional, } \\
\text { Textural and flowing } \\
\text { Properties of HPDF }\end{array}$} \\
\hline & No & \\
\hline & & \\
\hline
\end{tabular}




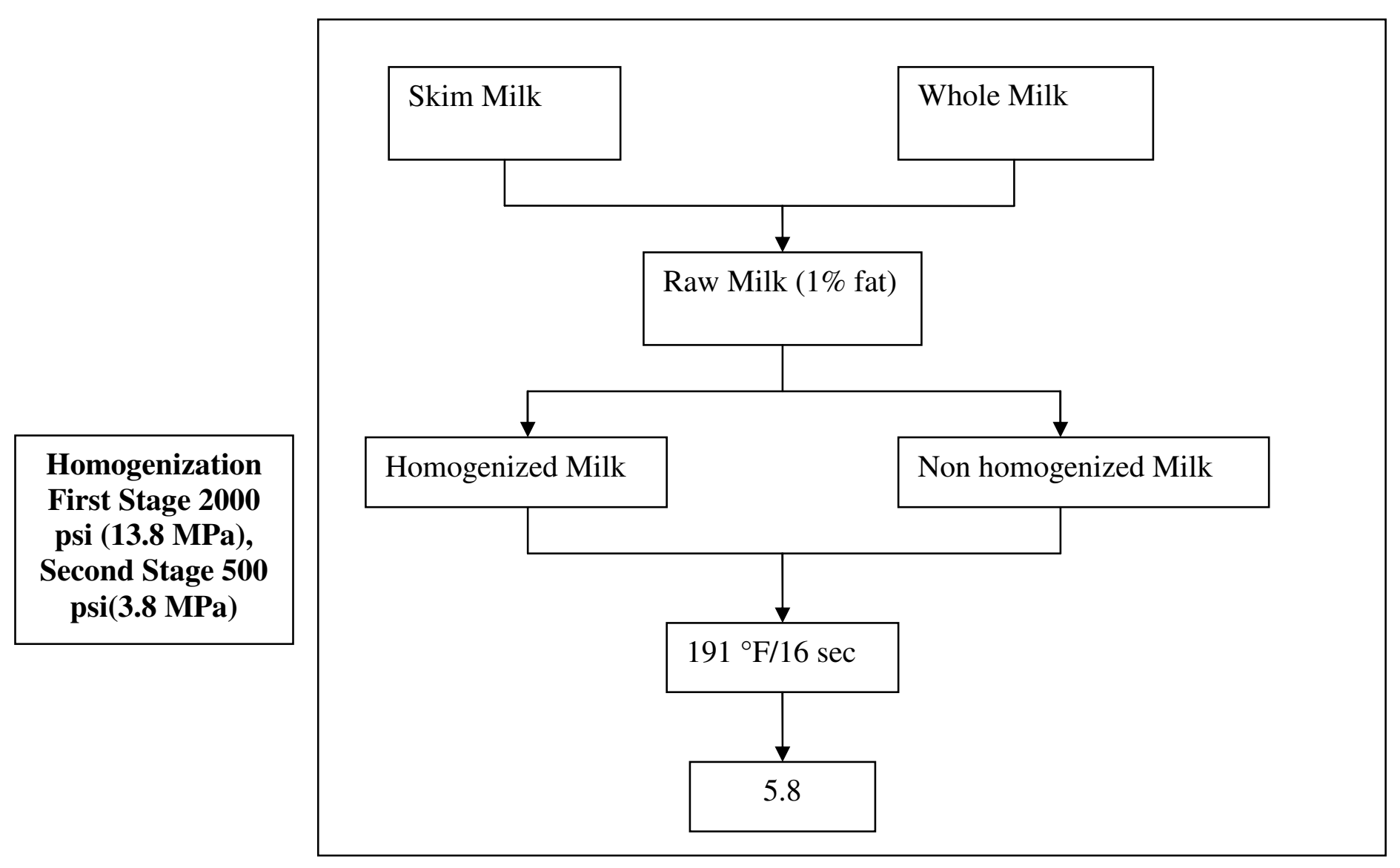

Figure 4.6.Flow chart for experimental design 3: effect of homogenization on compositional, textural and flowing quality of HPDF.

\subsection{Manufacture of HPDF}

\subsubsection{Standardization of fat in raw milk}

Twenty gallons (75.71 liters) of fresh raw milk was picked up from CalPoly dairy per 4 batches of food manufacture. The raw milk was tasted for aroma, $\mathrm{pH}$ and temperature. The usual $\mathrm{pH}$ of milk is in the range of $6.7-6.9$ and that of the temperature is $30-40^{\circ} \mathrm{F}\left(1-5^{\circ} \mathrm{C}\right)$. The raw milk was subjected to Babcock fat test (as described in section 4.5.1.3), and percent fat is analyzed. The fat was standardized to $1 \%$ with skim milk (provided by campus dining) with Pearson square method.

After the milk is standardized to $1 \%$ fat, it was again subjected to Babcock fat analysis and \% fat in standardized milk was determined. If the resultant fat in standardized milk was not $1 \%$, the milk was again standardized by addition of raw milk/skim milk. Subsequently, the milk was taken in 
the balance tank of HTST pasteurizer (PMS Processing Machinery and Supply Co., Philadelphia, PA) and pasteurized to stated temperature (as per design of experiment in 4.2) for 16 seconds. If the experimental design involved homogenization process, the milk was subjected to homogenization after regeneration at temperature of $130-140^{\circ} \mathrm{F}\left(54.4-60^{\circ} \mathrm{C}\right)$ (Niro soave Homogenizer) with first stage homogenization pressure of $13.8 \mathrm{Mpa}(2000 \mathrm{psi})$ and second stage homogenization pressure of 3.5 MPa (500 psi). The pasteurized milk was collected in previously cleaned, sanitized stainless steel cans of 10 gallons and transferred to milk cold storage immediately. All the standardized milk was utilized within 3 days of processing.

\subsubsection{Other ingredients}

4.3.2.1. Rennet: Chy-max milk clotting enzyme produced by $100 \%$ fermentation was obtained from Chr. Hansen's Lab., Milwaukee, WI. The rennet solution was dissolved in chlorine-free warm water at ratio of 1:25 (rennet: water).

4.3.2.2. Vinegar: Food grade acetic Acid (5\% v/v) was obtained from Albertsons, San Luis Obispo, CA. It was diluted to $2 \%(\mathrm{v} / \mathrm{v})$ by addition of tap water.

4.3.2.3. Calcium chloride: $2.88 \mathrm{M}$ solution of $\mathrm{CaCl}_{2}$

\subsubsection{Manufacture HPDF:}

The pasteurized standardized milk (as described in section 4.3.1) was transferred in previously cleaned, sanitized cheese vat (Kusel equipment, WI). The $\mathrm{pH}$ and temperature of the milk was determined at each step of manufacturing with $\mathrm{pH}$ meter (Oakton waterproof Big display $\mathrm{pH}$ meter) with food grade special electrode (Figure 4.7). 


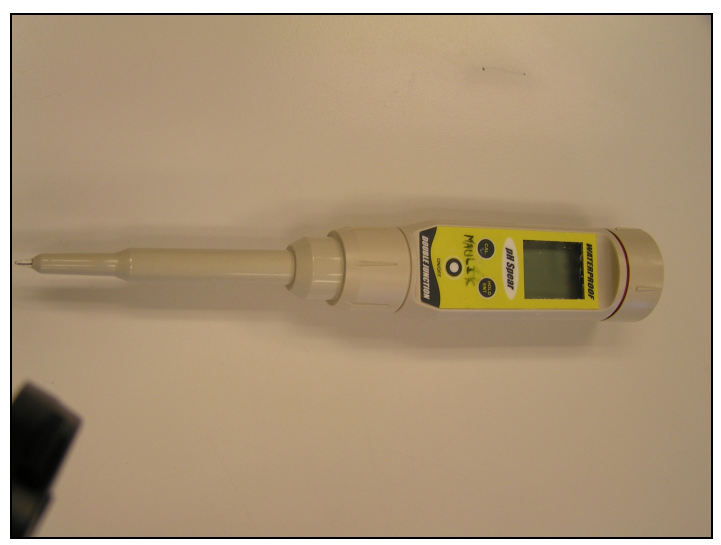

Figure $4.7 \mathrm{pH}$ meter with special food grade electrode

The $\mathrm{pH}$ meter was calibrated with certified buffer solutions (Fisher Scientific, Fair Lawn, NJ) of pH 4.0, 7.0 and 10.0 before starting of manufacture. Record of $\mathrm{pH}$, temperature and acidity were maintained along with batch number and date for each batch. Figure 4.7 shows the detailed flow chart for manufacture of HPDF. The $\mathrm{pH}$ of acidification is as per the experimental design (as described in section 4.2) of each batch.

All the HPDF was stored in cheese cold storage at $40-45^{\circ} \mathrm{F}\left(4.44-7.22^{\circ} \mathrm{C}\right)$. A block of sample $\left(17.5 \times 9.5 \times 9 \mathrm{~cm}^{3}\right)$ from each batch was drawn within 24 hour of manufacture and analyzed for composition, flowing and textural properties (as described in section 4.4). It was also subjected to the various food preparation method described in section 4.5. 


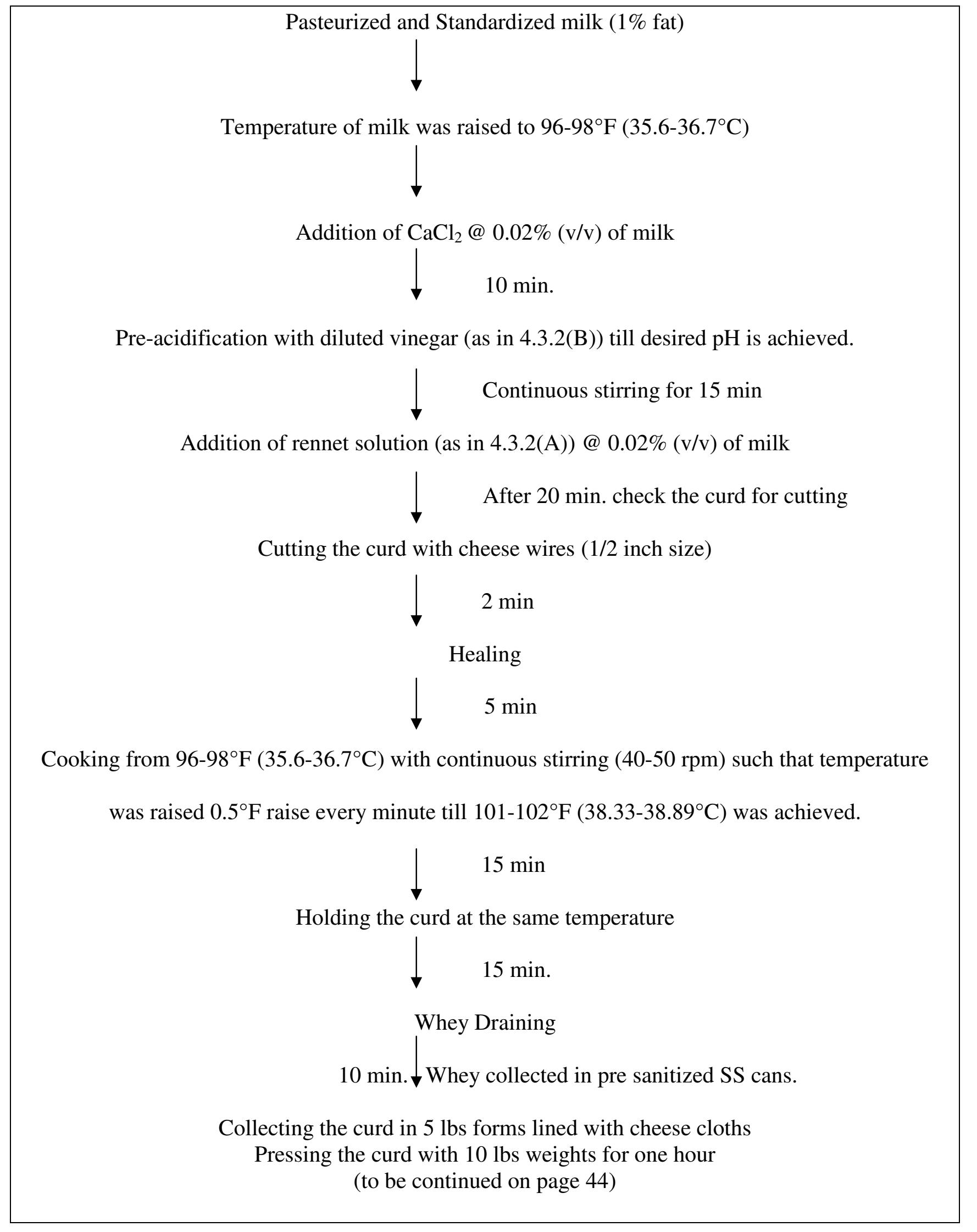


(continued from page 43)

Cutting the hooped curd in 5-6 small rectangular pieces-17.5X9.5X9 (LXBXH) $\mathrm{cm}^{3}$ size with presanitized stainless steel knife

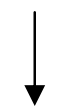

Transferring the curd pieces in a kettle filled with 20 gallons of sweet whey collected during syneresis with $\mathrm{pH}>6.0$ and temperature $5-10^{\circ} \mathrm{F}$.

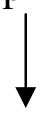

Heating the curd-whey mixture to $180-185^{\circ} \mathrm{F}\left(82.22-85^{\circ} \mathrm{C}\right)$ in the jacketed kettle

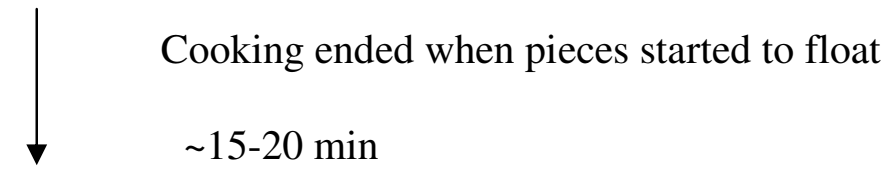

Draining of hot whey and scooping out cooked curd pieces on a pre-sanitized SS trolley

Air cooling of curd pieces to room temperature and transferring the trolley in cold store maintained at $10-15^{\circ} \mathrm{F}$ for $4-6$ hours

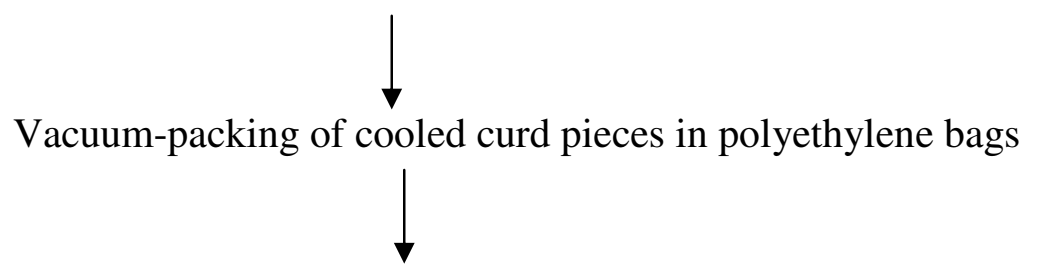

Labeling, stacking on plastic crates and transferring in cheese cold storage maintained at $5^{\circ} \mathrm{F}$.

Figure 4.8 Flow chart for manufacture of HPDF.

\subsection{Analysis of HPDF}

\subsubsection{Compositional Analysis}

The compositional analysis of HPDF was performed in duplicate and involved analysis of total protein, moisture and fat content. 


\subsubsection{Total Protein Content}

Total nitrogen content of all samples using $1 \mathrm{~g}$ cheese sample was determined by Kjeldahl method-AOAC (16th edition, volume 2) 1995 official method 990.123 using the Tecator 2020 Digestor (Perstorp Analytical Company, Sweden) and Kjeltec 2200 Auto Distillation Unit (FOSS Instruments, Sweden). Percentage total protein was calculated from percentage total nitrogen multiplied by the conversion factor 6.38 .

\subsubsection{Moisture content}

Moisture in sample was determined by vacuum oven method-AOAC (16th edition, volume 2) 1995 official method 926.08 using vacuum oven model 281A (Fisher Scientific, Tustin, CA).

\subsubsection{Fat content}

Fat content in sample was determined by Babcock Method outlined in Standard Methods for the Examination of Dairy Products 15.083(17th edition, 2004).

\subsubsection{Texture Profile Analysis}

Texture analysis was performed using the TA-XT2 texture analyzer (Texture Technology Corp., Scarsdale, NY). Texture parameters were analyzed using Expert Version 1.22 software (Stable Micro Systems, Scarsdale, NY). Samples were cut into 20mmX20mmX20mm cubes and stored in the refrigerator at $4^{\circ} \mathrm{C}$ for 2 hour. Prior to analysis, the samples were tempered at room temperature $\left(22-25^{\circ} \mathrm{C}\right)$ for $30 \mathrm{~min}$. Triplicate analysis of samples was performed within $5 \mathrm{~min}$. A 75 $\mathrm{mm}$ compression plate probe and $50 \%$ compression was used.

The text mode was set s TPA. The pre-test speed was set as $1.2 \mathrm{~mm} / \mathrm{sec}$. The test speed was set as $1.2 \mathrm{~mm} / \mathrm{sec}$. The post-test speed was set as $1.2 \mathrm{~mm} / \mathrm{sec}$. The compression was set as $50 \%$. The time was set as $5.00 \mathrm{sec}$. The trigger type was set as Auto and the force was set as $5 \mathrm{~g}$. The stop plot was set as 'Trigger Return'. The test was carried out on P75-75 mm Compression Plate. 


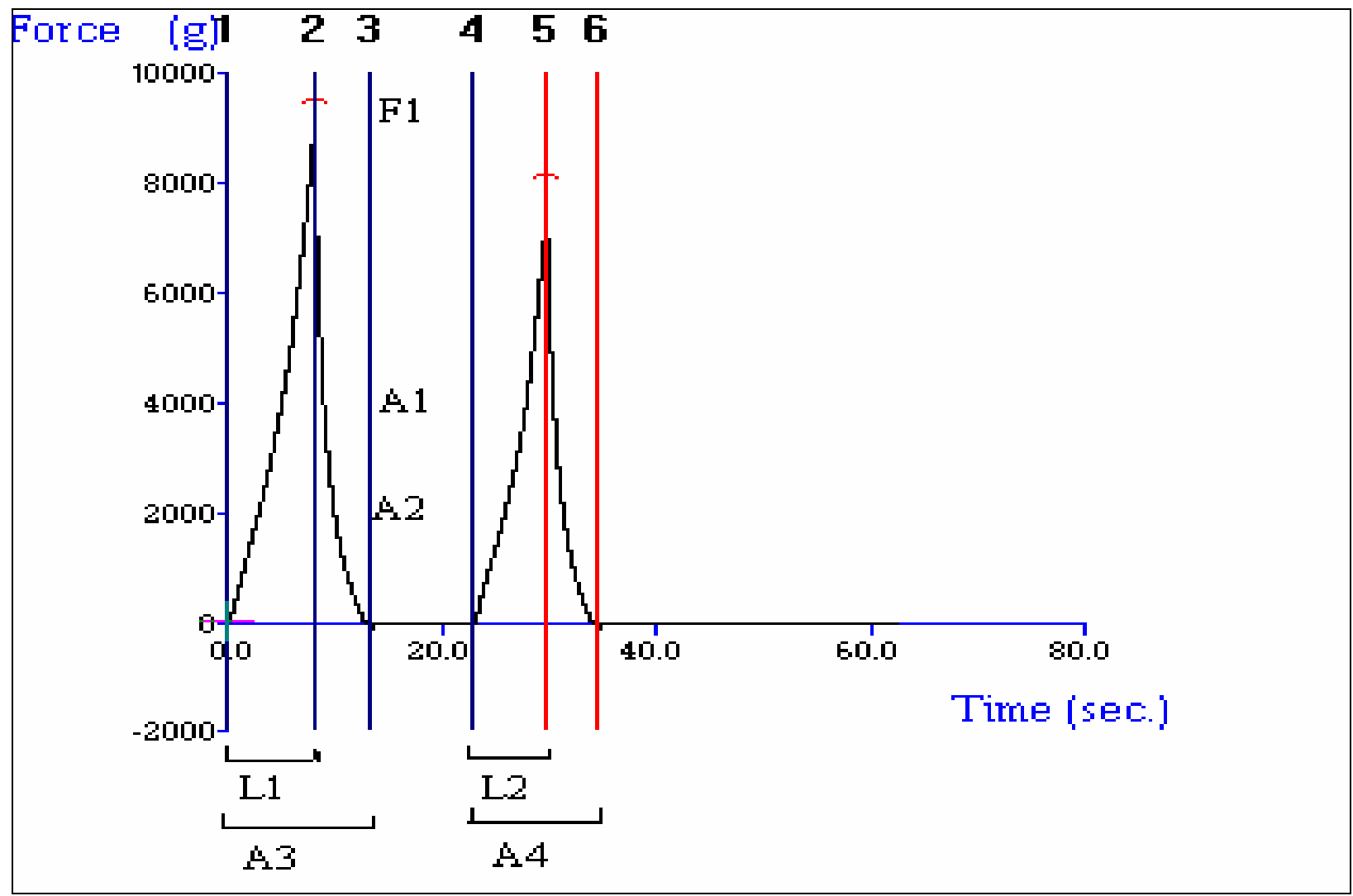

Figure 4.9 Texture Profile of HPDF obtained from TA-XT2 texture analyzer at room temperature on $2 * 2 * 2 \mathrm{~cm}$ sample

Texture parameters were determined from force vs. time curve obtained (as per figure 4.9) by using following calculations.

A denotes Area under the curve and L denotes Length of the curve in TPA graph. The calculation of Hardness ( $\mathrm{g}$ ) is defined as Force (F1) in the TPA profile. Cohesiveness is defined as A4/A3. Springiness is defied as L2. Gumminess ( $\mathrm{g}$ ) is defined as product of Hardness and Cohesiveness. Chewiness (g) is defined as product of Hardness Cohesiveness and Springiness. 


\subsubsection{Analysis of Flow Properties}

Evaluation of flow properties was one of the main objectives of the project. To ensure that the newly developed HPDF has flow resistant properties, it was subjected to various heat treatments at different time temperature combinations. The basic principle is based on the Schreiber test described by Kosikowki (1977) for process cheese. In the test, a cylindrical sample of $56 \mathrm{~mm}$ diameter and $5 \mathrm{~mm}$ height was pushed out with a sharp edge cookie cutter with $56 \mathrm{~mm}$ internal diameter. The sample in a thin walled glass Petri-dish $(150 \mathrm{~mm}$ diameter* $20 \mathrm{~mm}$ height $)$ was subject to three different distinct heat treatments. The sample was then centered over a concentrically numbered target-type graph numbered zero to eight with "zero" flow value corresponding to $56 \mathrm{~mm}$ diameter circle. Each subsequent circle has increase in diameter by $10 \mathrm{~mm}$. The maximum flow value is 8 , which is corresponding to $136 \mathrm{~mm}$ diameter circle. Looking through the uncovered glass Petri dish, the outer edge of the flow line was marked. The flow value corresponding to the circle was recorded numerically (Figure 4.10).

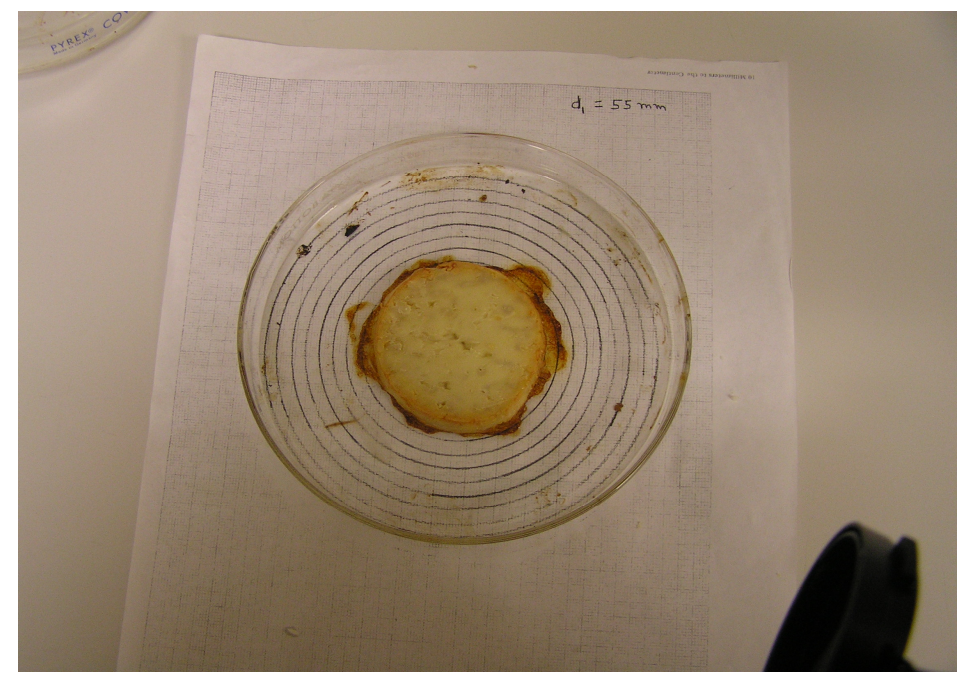

Figure 4.10 sample of HPDF subjected to heat treatment in a Petri dish and centered over a grid of concentric circles and flow value recorded.

The sample of HPDF was subjected to three main mode of heating. 


\section{Heating in Oven}

\section{Heating in Microwave}

\section{Heating in boiling water}

All three heat treatment subjected the sample to three different mode of heat transfers. Heating in oven was dry heat, whereas heating in boiling water was wet heat. Heating in microwave was short but intense heat treatment. The heat thermal energy provided to the sample was different for all of these heat treatments. Internal temperature of the sample was recorded immediately at the end of each heat treatment.

\subsubsection{Heating in oven}

The cylindrical sample of HPDF in glass Petri-dish (on top of an aluminum plate) was placed on the rack of forced draft convection oven (General Electric, Luisville, KY-120/240 V, 6.8 kW) and subjected to heat treatment of $450^{\circ} \mathrm{F}\left(232.22^{\circ} \mathrm{C}\right)$ for $15 \mathrm{~min}$ (figure 4.11) The internal temperature of the sample was $280-285^{\circ} \mathrm{F}\left(137.77-140.5^{\circ} \mathrm{C}\right)$ when the sample was removed from the oven. After $15 \mathrm{~min}$, the Petri-dish was removed with thermal safety gloves and allowed to cool on a flat surface for $30 \mathrm{~min}$. Next, the flow value of the cooled sample was noted with the concentric circled graph as described above.

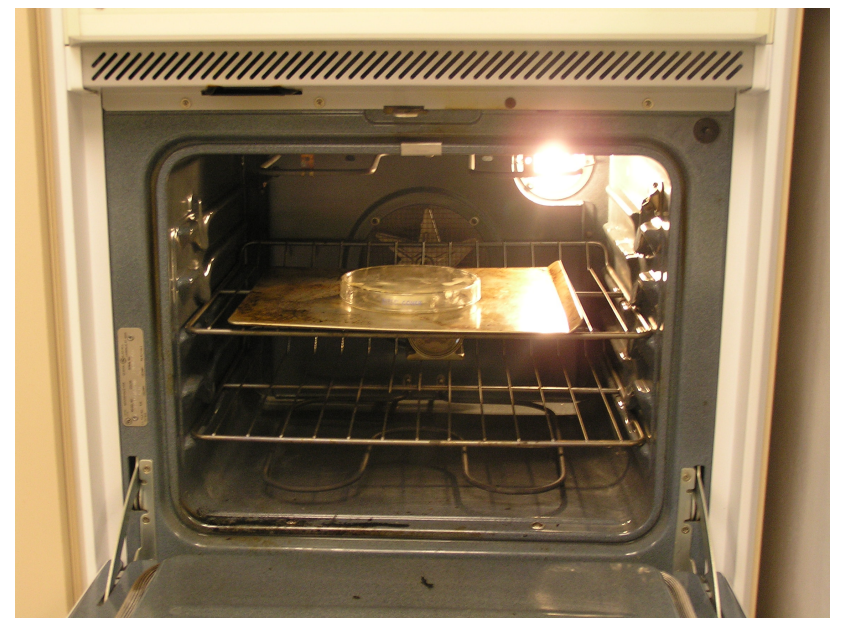

Figure 4.11 Sample of HPDF heated in convection oven at $450^{\circ} \mathrm{F}$ for $15 \mathrm{~min}$. 


\subsubsection{Heating in microwave}

The cylindrical sample of HPDF in glass Petri-dish was placed at the center of microwave (General Electric, Louisville, KY 1.5 KW $120 \mathrm{~V} \mathrm{AC/60} \mathrm{Hz)} \mathrm{and} \mathrm{subjected} \mathrm{to} \mathrm{heat} \mathrm{treatment} \mathrm{for} 1$ min. on full power. The internal temperature of the sample was reported to be $360-380^{\circ} \mathrm{F}(182.22$ $193.33^{\circ} \mathrm{C}$ ) at the end of the heat treatment. After $1 \mathrm{~min}$, the Petri-dish was removed with thermal safety gloves and allowed to cool on a flat surface for $30 \mathrm{~min}$. Next, the flow value of the cooled sample was noted with the concentric circled graph as described above.

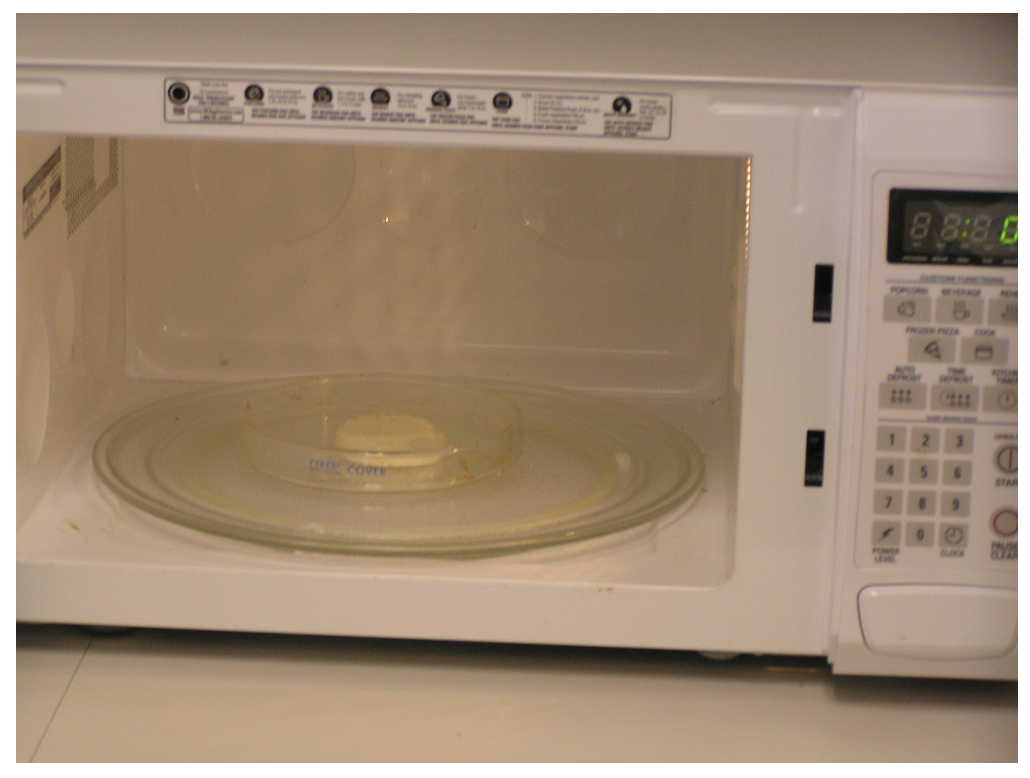

Figure 4.12 Sample of HPDF heated in microwave for $1 \mathrm{~min}$.

\subsubsection{Heating in boiling water}

The cylindrical sample of HPDF in glass Petri-dish was placed inside the boiling water bath and subjected to heat treatment $212^{\circ} \mathrm{F}\left(100^{\circ} \mathrm{C}\right)$ for $10 \mathrm{~min}$ (Figure 4.13) on full power. The internal temperature of the sample was reported to be $183-186^{\circ} \mathrm{F}\left(83.83-85.56^{\circ} \mathrm{C}\right)$ at the end of heat treatment. After 10 min, the Petri-dish was removed with thermal safety gloves and allowed to cool on a flat surface for $30 \mathrm{~min}$. Next, the flow value of the cooled sample was noted with the concentric circled graph as described above. The internal temperature of the sample was also recorded. 


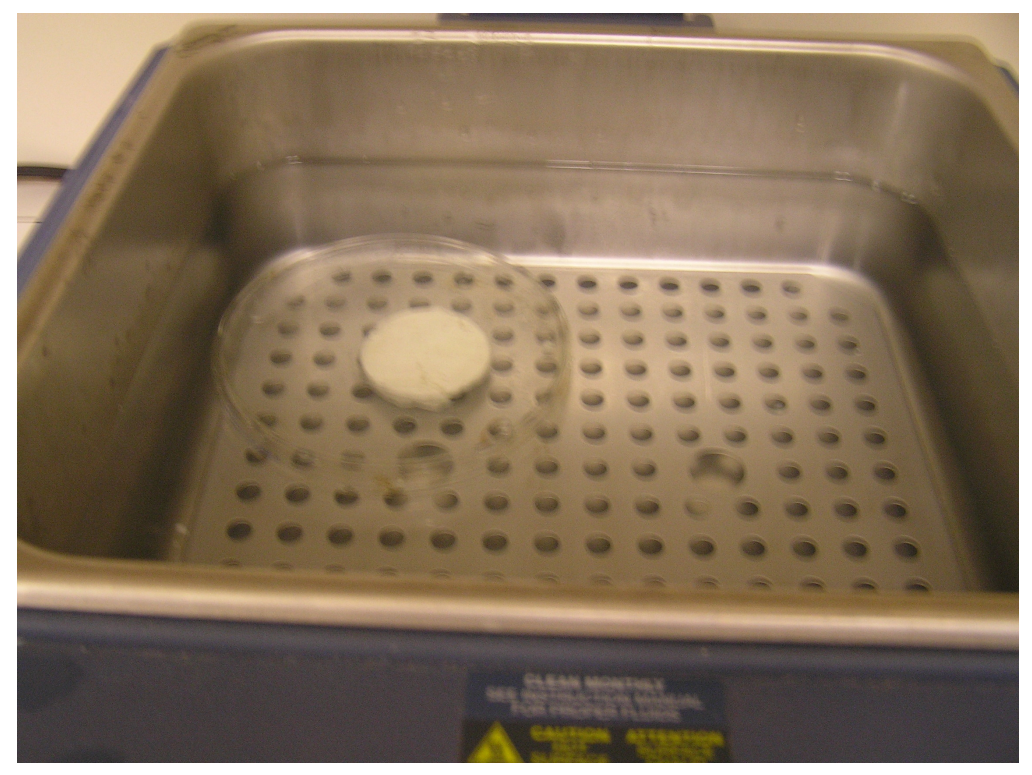

Figure 4.13 Sample of HPDF heated in boiling water for $10 \mathrm{~min}$.

\subsection{HPDF preparation method}

In order to check the applicability of newly developed HPDF as tofu alternative, various recipes involving tofu in different mode of heat treatment were studied. Based on these studies, three recipes were chosen with three distinct modes of heat treatments. All recipes were prepared with fresh HPDF.

1. Dry heating

2. Heating in oil with agitation

3. Heating in hot water with agitation.

These modes of heating are described in detail in sections 4.5.1-4.5.3. 


\subsubsection{Dry Heating/Baking}

This mode of application is designed to access the behavior of HPDF under conventional oven. This application was designed keeping in mind the use of HPDF as commercial baked tofu alternative. For this application, a soy sauce marinade was prepared by mixing soy sauce with 2 tablespoons of honey, 2 tablespoons balsamic vinegar, 1.5 tablespoons grated fresh ginger and 1 tablespoon minced garlic.

The detailed flow chart of preparation method is as figure 4.14:

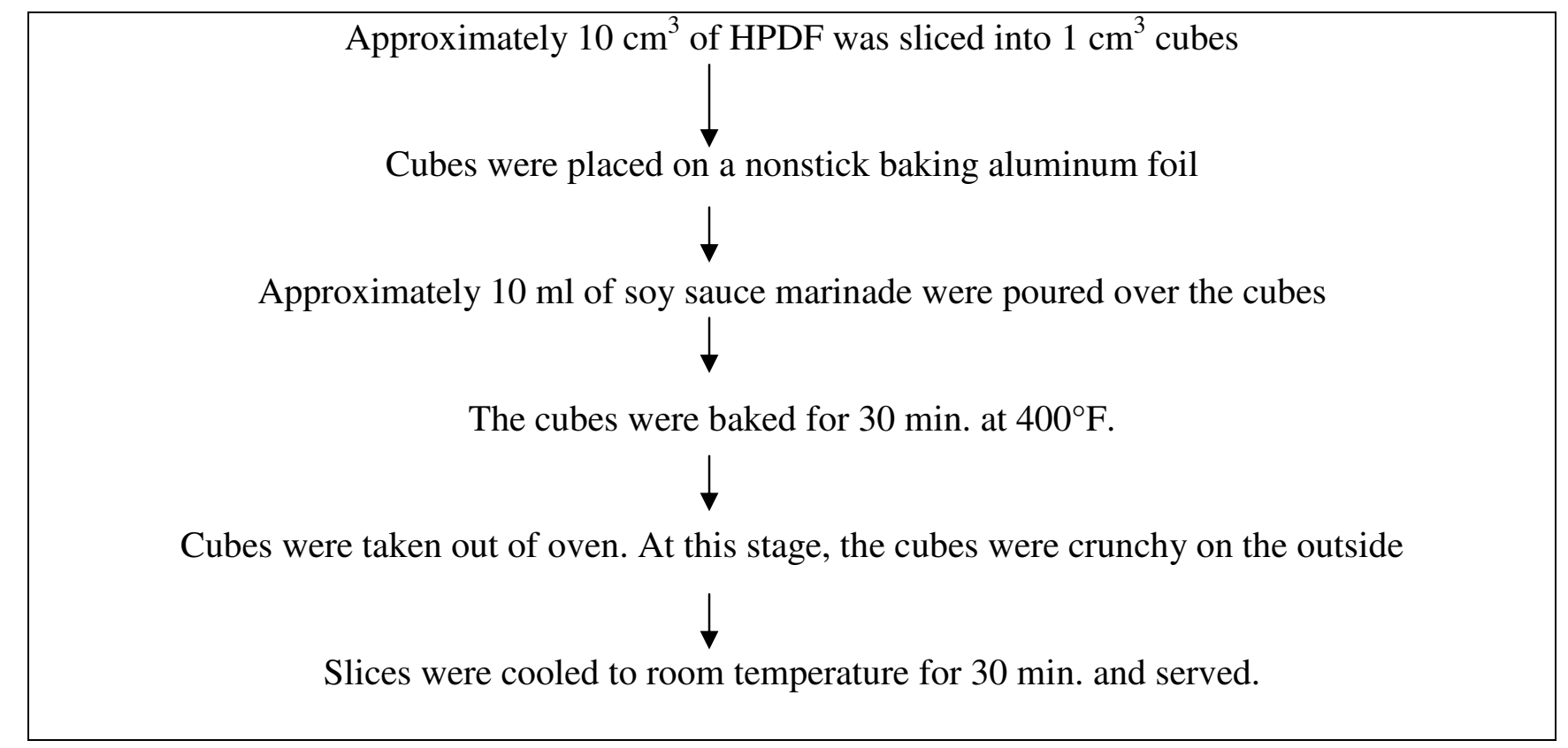

Figure 4.14.Flow chart for the baking of HPDF.

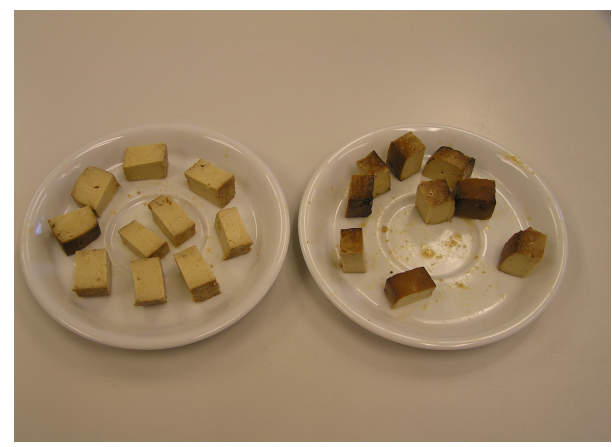

Figure 4.15 image of baked HPDF 


\subsubsection{Heating in oil with agitation/Stir frying}

Approximately $1 \mathrm{lb}$ of freshly made HPDF was blot-dried with clean towels and then cut into $1 \mathrm{~cm}^{3}$ cubes. Next, 3 to 4 scallions (green spring onion) were washed and thinly sliced with thin knife into one mm thick slices. Same way, $1 \mathrm{lb}$ of bok choy was washed and thinly sliced crosswise and rinsed. 2 cloves of garlic were also minced.

After the HPDF and vegetables are ready to cook, they were cooked as in figure 4.16 for the preparation of stir frying of HPDF.

2-3 tablespoons of olive oil was heated to $212^{\circ} \mathrm{F}\left(100^{\circ} \mathrm{C}\right)$ in a stir fry pan

Freshly made sliced HPDF was added in the pan and stir fried over medium heat until golden on most sides.

$\downarrow$

Sliced bok choy, scallions, garlic, 3-4 table spoon of stir-fry sauce and about 2 tablespoons of water were added in the pan

The vegetables were stirred together quickly for 3-4 minutes, just until the bok choy and its leaves were wilted

0.25 cup of coarsely chopped peanuts were added and served.

Figure 4.16 flow chart for the stir-frying of HPDF.

\subsubsection{Wet heat/ Soup making}

Approximately $1 \mathrm{lbs}$ of freshly made HPDF was sliced into $1 \mathrm{~cm}^{3}$ cubes. 1 large carrot, 1/4 cup of fresh coriander leaves, 4 green onions and 8 fresh mushrooms were washed and sliced. 2 cloves of garlic were crushed. Approximately 3 tablespoons of soybean paste (Brown Rice Miso) was dissolved in $1 / 4$ cup of warm water. The rest of procedure for making soup is as per figure 4.17. 


\section{4 cups of water was boiled in a large pot}

$\downarrow$

sliced carrot, mushrooms and garlic were added in water.

The mixture was simmered to boiling (approx. $\sim 100^{\circ} \mathrm{C}$ ) for 10 minutes

The cubed HPDF and miso were added and simmered for 2 minutes

Final soup was garnished with green onions and coriander leaves.

Figure 4.17 flow chart of making miso soup from HPDF (Ang E.T., 1996)

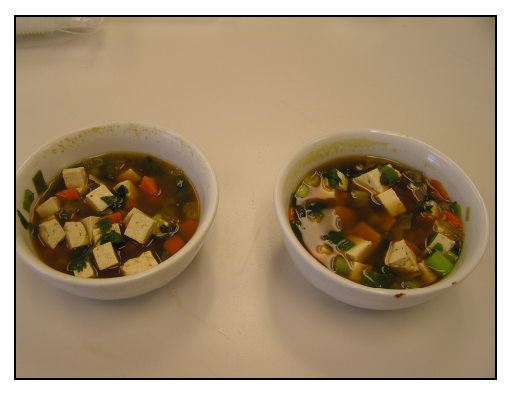

Figure 4.18 image of miso soup made from HPDF.

\subsection{Comparison with commercial Tofu and Halloumi}

Commercial tofu and halloumi cheese were purchased at New Frontier grocery store in San Luis Obispo, California. The brand used in case of halloumi was Mount Vikos (Mount Vikos Inc., Marshfield, MA). The extra firm, firm and silken tofu were Nasoya brand (Vitasoy USA Inc., MA). The reduced fat tofu was West Soy (Hain celestial group, NY) and baked tofu was Royal Thai brand (Pulmuone Wildwood Inc., CA)

The comparison was made with two different HPDF manufactured from non homogenized milk pasteurized at $191^{\circ} \mathrm{F}$ for $16 \mathrm{sec}$ and acidified at $\mathrm{pH} 5.8$ and 6.2. The type of commercial tofu was extra firm, firm, silken, reduced fat and baked with a variety of texture. The commercial halloumi was made traditionally from sheep milk. All samples purchased prior to analysis were stored at $4^{\circ} \mathrm{C}$ in refrigerator. 


\subsubsection{Texture profile analysis}

The hardness of all the commercial samples were evaluated as described in section 4.4.3. The difference in hardness of HPDF and commercial samples was evaluated statistically with General Linear Model analysis of Variance (ANOVA) in MINITAB software (v. 15, Minitab Inc., State College, Pennsylvania).

\subsection{Limited focus group survey on food preparation}

To evaluate the suitability of HPDF, various recipes mainly involving tofu were prepared as described in section 4.5. Each of these recipes was made with tofu (as control) as sample A and HPDF as sample B. Each of these recipes was given to 12 random panelists from Dairy Product Technology Center of California Polytechnic State University, San Luis Obispo on each day within

30 minute of cooking. The identity of sample A and sample B were kept confidential. The panelists were given a brief questionnaire for each recipe (as in Appendix A) involving their familiarity with the recipe, if there is a difference in the texture between sample $\mathrm{A}$ and $\mathrm{B}$ and their preference for sample A or sample B.

The results of the Limited focus group survey were analyzed with chi-square test for significance in MINITAB software.

\subsection{Statistical Analysis}

The statistical analysis of composition (fat, protein and moisture content), texture (hardness, chewiness, gumminess, springiness and cohesiveness) and flow properties (under convection oven, microwave and hot water) was carried out using General Linear Model analysis of variance (ANOVA) in the Minitab software (v. 15, Minitab Inc., State College, Pennsylvania).The factors investigated were effect of pasteurization condition, $\mathrm{pH}$ of acidification and homogenization. 


\subsection{Result and Discussion}

\subsection{Preliminary Trial}

As described in section 4.1, the HPDF was manufactured by manufacturing process similar to Halloumi cheese. The first step of preliminary trials was to identify upper and lower levels within each processing treatment. i.e. pasteurization condition, $\mathrm{pH}$ of acidification and homogenization. The second step was to understand whether there is an effect of the upper and lower levels of the treatment on properties specifically flowability of HPDF. As mentioned in section 4.2, the higher and lower levels of pasteurization conditions were $161^{\circ} \mathrm{F}\left(71.7^{\circ} \mathrm{C}\right) / 16 \mathrm{sec}$ and $191^{\circ} \mathrm{F}(88.3) / 16 \mathrm{sec}$, the higher and lower levels of $\mathrm{pH}$ of acidification of milk were 5.8 and 6.6 and the two levels of homogenization of milk were yes/no (homogenization and no homogenization).

Based on the level of treatments, 6 batches of HPDF were manufactured. Since one of the main desired properties for HPDF was that it should resist the flow under heat induced stress, flowability of each batch was determined. The results of these preliminary trials are presented in table 5.0 and Figure 5.0. There was marked difference in the flow properties of HPDF for the two pasteurization conditions. The HPDF manufactured from milk pasteurized at $191^{\circ} \mathrm{F} / 16 \mathrm{sec}$ showed marked flow resistant under heat induced stress from oven, microwave and hot water as compare to the one manufactured from milk pasteurized at $161^{\circ} \mathrm{F} / 16 \mathrm{sec}$. For the same pasteurization condition and $\mathrm{pH}$, HPDF produced from homogenized milk showed slightly higher flow resistance as compared to the one manufactured from non homogenized milk (table 5.0 and Figure 5.0). For the $\mathrm{pH}$ of acidification, the effect depended on the pasteurization conditions. For the same homogenization conditions, the HPDF showed slight lower flow at $\mathrm{pH} 5.8$ than $\mathrm{pH} 6.6$ for $191^{\circ} \mathrm{F} / 16$ sec. (table 5.0 and Figure 5.0) whereas the HPDF made at $\mathrm{pH} 6.6$ were flow resistant than that of made at $\mathrm{pH} 5.8$ for $161^{\circ} \mathrm{F} / 16 \mathrm{sec}$. 
'Flow unit' was defined as $10 \mathrm{~mm}$ of flow under heating condition and 'flow unit' of 1 or more than 1 was defined as HPDF with flow properties whereas 'flow unit' of less than 1 was defined as HPDF with flow resistance.

The experiment was meant for screening and hence there were no replicates, hence the effect of pasteurization, the effect of homogenization and $\mathrm{pH}$ of acidification on flowability was still a matter of investigation. Based on these preliminary studies, further experiments were designed to study the contribution of each treatment independently as well as in combination on flow properties.

Table 5.0 Preliminary trial on flowability of HPDF under different processing conditions ( 1 flow unit $=10 \mathrm{~mm}$ flow, flow unit $<1$ is considered as flow resistance)

\begin{tabular}{|c|c|c|c|c|c|}
\hline homogenization & $\begin{array}{c}\mathrm{pH} \text { of } \\
(2000 \mathrm{psi} / 500 \mathrm{psi})\end{array}$ & acidification & pasteurization & flow & flow \\
\hline $\mathrm{Y}$ & 5.8 & $191^{\circ} \mathrm{F} / 16 \mathrm{sec}$ & 0.33 & 0.67 & 0.5 \\
\hline $\mathrm{Y}$ & 6.6 & $191^{\circ} \mathrm{F} / 16 \mathrm{sec}$ & 0.67 & 0.75 & 0.67 \\
\hline $\mathrm{N}$ & 5.8 & $191^{\circ} \mathrm{F} / 16 \mathrm{sec}$ & 0.67 & 1.33 & 0.5 \\
\hline $\mathrm{N}$ & 6.6 & $191^{\circ} \mathrm{F} / 16 \mathrm{sec}$ & 1 & 1.5 & 0.67 \\
\hline $\mathrm{N}$ & 5.8 & $161^{\circ} \mathrm{F} / 16 \mathrm{sec}$ & 7.5 & 8 & 6.67 \\
\hline $\mathrm{N}$ & 6.6 & $161^{\circ} \mathrm{F} / 16 \mathrm{sec}$ & 6 & 6.5 & 5.33 \\
\hline
\end{tabular}




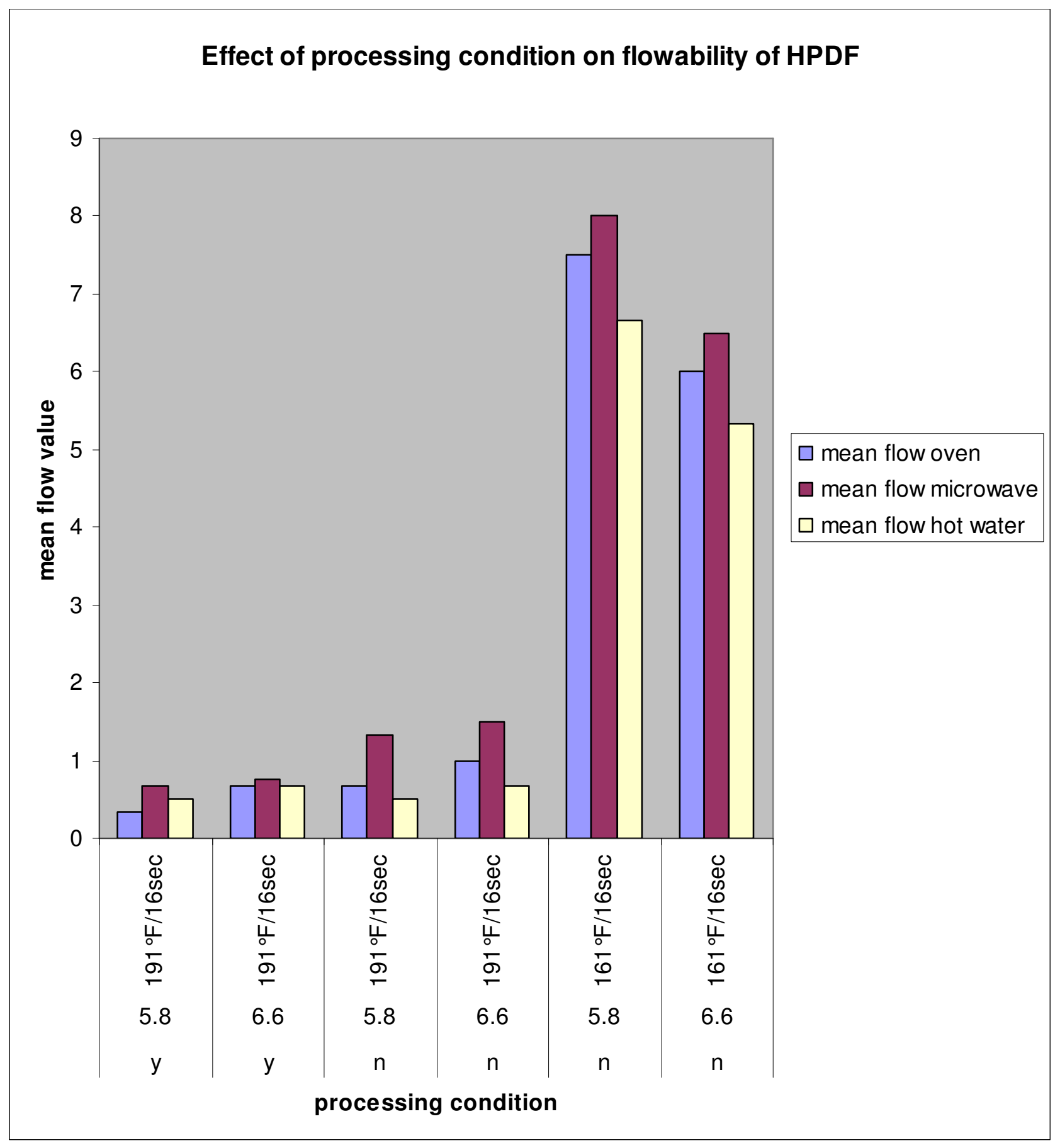

Figure 5.0 Preliminary trial on effect of processing conditions on flow properties of HPDF 


\subsection{Heat treatment, Homogenization and Acidification effect}

The first stage of experiment of studying effect of various processing parameter was comprised of 3 levels of pasteurization conditions $\left(161^{\circ} \mathrm{F} / 16 \mathrm{sec} ., 175^{\circ} \mathrm{F} / 16 \mathrm{sec}\right.$ and $\left.191{ }^{\circ} \mathrm{F} / 16 \mathrm{sec}\right)$, three levels of acidification $(5.8,6.2,6.6)$ and two levels of homogenization conditions (2000 psi/500 psi)(yes/no).

\subsubsection{Compositional Analysis}

The HPDF was analyzed for fat, protein and moisture content. The result of the analysis is as shown in the Table 5.1, 5.2 and 5.3.

\subsubsection{Fat Content}

From the Table 5.1, it is clear that fat content of the HPDF ranged from 10.5-11.0\%. The fat content was almost one third of the fat content of commercial cow milk halloumi (27-30\% fat) (Anifantakis \& Kaminarides, 1982, 1983). The milk was standardized at $1 \%$ fat, whereas in case of Halloumi, the standardized milk has 3-3.5\% fat (Robinson, 1991). All the p-values of mean fat are higher than 0.05 (Table 5.4) indicating that none of the factors (acidification, homogenization and pasteurization condition) are significant independently or in combination with each other. The result is surprising especially in light of effect of homogenization on redistribution of fat. Homogenization is known to influence the size of milk fat by reducing the size of the fat globules, but it did not affect the mean fat content of HPDF significantly.

\subsubsection{Protein and Moisture Content}

From Table 5.3, the protein content of HPDF made from high heated milk ranged from 2634\%. Figure 5.1, 5.2 and 5.3 indicates individual effects of heat treatment, acidification and homogenization on moisture and protein content of HPDF. Moisture content of the final product decreases with increase in heat treatment whereas the total protein content of final product increases as the milk is heated at elevated temperature. This may be explained by heat induced denaturation of 
serum protein and its subsequent association with casein micelles (Fox, 1981). In particular, the thiol group-disulphide bridge reaction between $\beta$-lactoglobulin and $\kappa$-casein are responsible for retention of part of denatured whey protein in the curd and hence increased protein content (Dannenberg and Kessler, 1988). The high heat treatment has been widely used in the industry particularly to increase the total solids and indirectly the yield of the final product. (Fox,1981).

From Table 5.2, 5.3 and Figure 5.2, it is clear that moisture content of HPDF acidified at pH 6.6 is higher than that of HPDF acidified at $\mathrm{pH}$ 5.8. The moisture content increases as the $\mathrm{pH}$ of acidification increases from 5.8 to 6.6 , whereas total protein content decreases with increase in $\mathrm{pH}$ from 5.8 to 6.6. At lower $\mathrm{pH}$, most of the whey proteins in milk are removed from the curd during syneresis, thus most of the protein network comprise of casein aggregates which has lower water retention ability. At higher $\mathrm{pH}$, the whey protein (particularly the one denatured by heat treatment) cross-linked with casein micelles, form a three dimensional network that can trap moisture inside the network. In this way, $\mathrm{pH}$ of acidification plays an important role in shaping the microstructure of the food and its mechanical properties.

The moisture content of HPDF made from non homogenized milk was lower than that of made from homogenized milk (Figure 5.3 and Table 5.3). Homogenization of milk reduces milk fat globule size and alters milk fat globule membrane (MFGM). It is also believed to create a new fatwater interface predominantly containing caseins that can make fat globules more stable (Rowney et al., 1999). Thus an increase in the area of lipid/water interface and redistribution of some of the casein makes a network that can retain more moisture and hence increase in the yield of final product. However, some of the casein (in casein micelles) migrates and becomes part of MFGM as the total surface area of fat globule increases during homogenization. Thus there is a decrease in available casein that can form a disulphide bond with denatured whey protein. This may be one of 
the reasons for decrease in total protein content of HPDF made from homogenized milk (Figure 5.3 and Table 5.2)

From Table 5.4, heating conditions, $\mathrm{pH}$ of acidification and homogenization are significant for mean protein and mean moisture of final product. In addition, there is an interaction between these factors for mean protein. The tukey $95 \%$ simultaneous confidence intervals response for mean protein on $\mathrm{pH}$ of acidification indicates mean protein (of HPDF) is significantly lower at $\mathrm{pH}$ of acidification 6.6 than that of $\mathrm{pH} 5.8$. Also, the mean moisture content of HPDF is higher when homogenized milk is used in the process of manufacture.

This statistical analysis suggests that the three factors chosen for studying compositional, textural and flow properties of HPDF- pasteurization condition, $\mathrm{pH}$ of acidification and homogenization are in fact, the factors that influence compositional properties of HPDF. 
Table 5.1 Mean fat content of different HPDF (for sample size $n=2$ )

\begin{tabular}{|c|c|c|c|c|c|}
\hline Batch & $\begin{array}{l}\mathrm{pH} \text { of } \\
\text { acidification }\end{array}$ & $\begin{array}{l}\text { pasteurization } \\
\text { condition }\end{array}$ & Homogenization & mean fat & $\begin{array}{l}\text { Standard } \\
\text { error }\end{array}$ \\
\hline 1 & 6.6 & $161^{\circ} \mathrm{F} / 16 \mathrm{sec}$ & Yes & 10.75 & 0.35 \\
\hline 2 & 5.8 & $191^{\circ} \mathrm{F} / 16 \mathrm{sec}$ & No & 10.75 & 0.35 \\
\hline 3 & 5.8 & $175^{\circ} \mathrm{F} / 16 \mathrm{sec}$ & no & 11 & 0.00 \\
\hline 4 & 6.2 & $175^{\circ} \mathrm{F} / 16 \mathrm{sec}$ & no & 10.75 & 0.35 \\
\hline 5 & 5.8 & $175^{\circ} \mathrm{F} / 16 \mathrm{sec}$ & yes & 10.5 & 0.00 \\
\hline 6 & 6.2 & $191^{\circ} \mathrm{F} / 16 \mathrm{sec}$ & no & 11.25 & 0.35 \\
\hline 7 & 5.8 & $191^{\circ} \mathrm{F} / 16 \mathrm{sec}$ & yes & 10.75 & 0.35 \\
\hline 8 & 6.2 & $175^{\circ} \mathrm{F} / 16 \mathrm{sec}$ & yes & 10.75 & 0.35 \\
\hline 9 & 6.2 & $161^{\circ} \mathrm{F} / 16 \mathrm{sec}$ & yes & 10.75 & 0.35 \\
\hline 10 & 5.8 & $161^{\circ} \mathrm{F} / 16 \mathrm{sec}$ & yes & 11 & 0.00 \\
\hline 11 & 6.6 & $175^{\circ} \mathrm{F} / 16 \mathrm{sec}$ & no & 11.25 & 0.35 \\
\hline 12 & 6.2 & $191^{\circ} \mathrm{F} / 16 \mathrm{sec}$ & yes & 10.75 & 0.35 \\
\hline 13 & 6.6 & $191^{\circ} \mathrm{F} / 16 \mathrm{sec}$ & no & 11 & 0.00 \\
\hline 14 & 6.6 & $175^{\circ} \mathrm{F} / 16 \mathrm{sec}$ & yes & 10.75 & 0.35 \\
\hline 15 & 6.6 & $191^{\circ} \mathrm{F} / 16 \mathrm{sec}$ & yes & 10.75 & 0.35 \\
\hline 16 & 6.6 & $161^{\circ} \mathrm{F} / 16 \mathrm{sec}$ & no & 10.75 & 0.35 \\
\hline 17 & 6.2 & $161^{\circ} \mathrm{F} / 16 \mathrm{sec}$ & no & 10.75 & 0.35 \\
\hline 18 & 5.8 & $161^{\circ} \mathrm{F} / 16 \mathrm{sec}$ & no & 10.5 & 0.00 \\
\hline
\end{tabular}


Table 5.2 Mean protein content of different HPDF (for sample size $n=3$ )

\begin{tabular}{|c|c|c|c|c|c|}
\hline Batch & $\begin{array}{l}\text { pH } \\
\text { acidification }\end{array}$ & $\begin{array}{l}\text { Pasteurization } \\
\text { condition }\end{array}$ & homogenization & Mean protein & $\begin{array}{l}\text { Std. dev. } \\
\text { Protein }\end{array}$ \\
\hline 1 & 6.6 & $161^{\circ} \mathrm{F} / 16 \mathrm{sec}$ & yes & 27.38 & 0.23 \\
\hline 2 & 5.8 & $191^{\circ} \mathrm{F} / 16 \mathrm{sec}$ & No & 30.27 & 0.29 \\
\hline 3 & 5.8 & $175^{\circ} \mathrm{F} / 16 \mathrm{sec}$ & No & 32.03 & 0.22 \\
\hline 4 & 6.2 & $175^{\circ} \mathrm{F} / 16 \mathrm{sec}$ & No & 31.58 & 1.07 \\
\hline 5 & 5.8 & $175^{\circ} \mathrm{F} / 16 \mathrm{sec}$ & yes & 30.58 & 0.49 \\
\hline 6 & 6.2 & $191^{\circ} \mathrm{F} / 16 \mathrm{sec}$ & No & 33.72 & 0.65 \\
\hline 7 & 5.8 & $191^{\circ} \mathrm{F} / 16 \mathrm{sec}$ & yes & 27.62 & 1.32 \\
\hline 8 & 6.2 & $175^{\circ} \mathrm{F} / 16 \mathrm{sec}$ & yes & 28.76 & 0.47 \\
\hline 9 & 6.2 & $161^{\circ} \mathrm{F} / 16 \mathrm{sec}$ & yes & 28.62 & 0.20 \\
\hline 10 & 5.8 & $161^{\circ} \mathrm{F} / 16 \mathrm{sec}$ & yes & 33.00 & 0.15 \\
\hline 11 & 6.6 & $175^{\circ} \mathrm{F} / 16 \mathrm{sec}$ & No & 33.85 & 0.05 \\
\hline 12 & 6.2 & $191^{\circ} \mathrm{F} / 16 \mathrm{sec}$ & yes & 28.54 & 0.40 \\
\hline 13 & 6.6 & $191^{\circ} \mathrm{F} / 16 \mathrm{sec}$ & No & 31.63 & 0.21 \\
\hline 14 & 6.6 & $175^{\circ} \mathrm{F} / 16 \mathrm{sec}$ & yes & 30.00 & 0.47 \\
\hline 15 & 6.6 & $191^{\circ} \mathrm{F} / 16 \mathrm{sec}$ & yes & 26.94 & 0.64 \\
\hline 16 & 6.6 & $161^{\circ} \mathrm{F} / 16 \mathrm{sec}$ & No & 26.47 & 0.32 \\
\hline 17 & 6.2 & $161^{\circ} \mathrm{F} / 16 \mathrm{sec}$ & No & 30.33 & 0.27 \\
\hline 18 & 5.8 & $161^{\circ} \mathrm{F} / 16 \mathrm{sec}$ & No & 32.48 & 0.40 \\
\hline
\end{tabular}


Table 5.3 Mean moisture content of different HPDF (For sample size $n=2$ )

\begin{tabular}{|c|c|c|c|c|c|}
\hline Batch & $\begin{array}{c}\text { pH of } \\
\text { acidification }\end{array}$ & $\begin{array}{c}\text { Pasteurization } \\
\text { condition }\end{array}$ & Homogenization & $\begin{array}{c}\text { mean } \\
\text { moisture }\end{array}$ & $\begin{array}{c}\text { standard } \\
\text { error }\end{array}$ \\
\hline 1 & 6.6 & $161^{\circ} \mathrm{F} / 16 \mathrm{sec}$ & Yes & 56.70 & 0.51 \\
\hline 2 & 5.8 & $191^{\circ} \mathrm{F} / 16 \mathrm{sec}$ & No & 54.23 & 0.04 \\
\hline 3 & 5.8 & $175^{\circ} \mathrm{F} / 16 \mathrm{sec}$ & No & 49.80 & 0.15 \\
\hline 4 & 6.2 & $175^{\circ} \mathrm{F} / 16 \mathrm{sec}$ & No & 49.90 & 0.42 \\
\hline 5 & 5.8 & $175^{\circ} \mathrm{F} / 16 \mathrm{sec}$ & Yes & 52.52 & 0.18 \\
\hline 6 & 6.2 & $191^{\circ} \mathrm{F} / 16 \mathrm{sec}$ & No & 54.37 & 0.07 \\
\hline 7 & 5.8 & $191^{\circ} \mathrm{F} / 16 \mathrm{sec}$ & Yes & 55.63 & 0.40 \\
\hline 8 & 6.2 & $175^{\circ} \mathrm{F} / 16 \mathrm{sec}$ & Yes & 55.17 & 0.48 \\
\hline 9 & 6.2 & $161^{\circ} \mathrm{F} / 16 \mathrm{sec}$ & Yes & 53.93 & 0.70 \\
\hline 10 & 5.8 & $161^{\circ} \mathrm{F} / 16 \mathrm{sec}$ & Yes & 47.81 & 0.01 \\
\hline 11 & 6.6 & $175^{\circ} \mathrm{F} / 16 \mathrm{sec}$ & No & 50.81 & 0.14 \\
\hline 12 & 6.2 & $191^{\circ} \mathrm{F} / 16 \mathrm{sec}$ & Yes & 56.44 & 0.08 \\
\hline 13 & 6.6 & $191^{\circ} \mathrm{F} / 16 \mathrm{sec}$ & No & 51.73 & 0.17 \\
\hline 14 & 6.6 & $15^{\circ} \mathrm{F} / 16 \mathrm{sec}$ & Yes & 53.57 & 0.06 \\
\hline 15 & 6.6 & $191^{\circ} \mathrm{F} / 16 \mathrm{sec}$ & Yes & 56.87 & 0.13 \\
\hline 16 & 6.6 & $11^{\circ} \mathrm{F} / 16 \mathrm{sec}$ & No & 56.13 & 0.78 \\
\hline 17 & 6.2 & $11^{\circ} \mathrm{F} / 16 \mathrm{sec}$ & No & 50.02 & 0.02 \\
\hline 18 & 5.8 & $161^{\circ} \mathrm{F} / 16 \mathrm{sec}$ & No & 50.45 & 0.10 \\
\hline
\end{tabular}


Table 5.4 p-values of test of significance of mean protein, fat and moisture at different acidification, pasteurization and homogenization levels.

\begin{tabular}{|c|c|c|c|}
\hline Factors & mean protein & mean fat & mean moisture \\
\hline Acidification & $\mathbf{0 . 0 4 2}$ & 0.621 & 0.087 \\
\hline Pasteurization & $\mathbf{0 . 0 4 4}$ & 0.621 & $\mathbf{0 . 0 5 1}$ \\
\hline Homogenization & $\mathbf{0 . 0 0 2}$ & 0.238 & $\mathbf{0 . 0 2 6}$ \\
\hline Acid ${ }^{*}$ past & $\mathbf{0 . 0 0 9}$ & 0.718 & 0.089 \\
\hline acid*homo & 0.148 & 0.621 & 0.248 \\
\hline past*homo & $\mathbf{0 . 0 1 9}$ & 0.208 & 0.289 \\
\hline
\end{tabular}




\section{Effect of Heat treatment on composition}

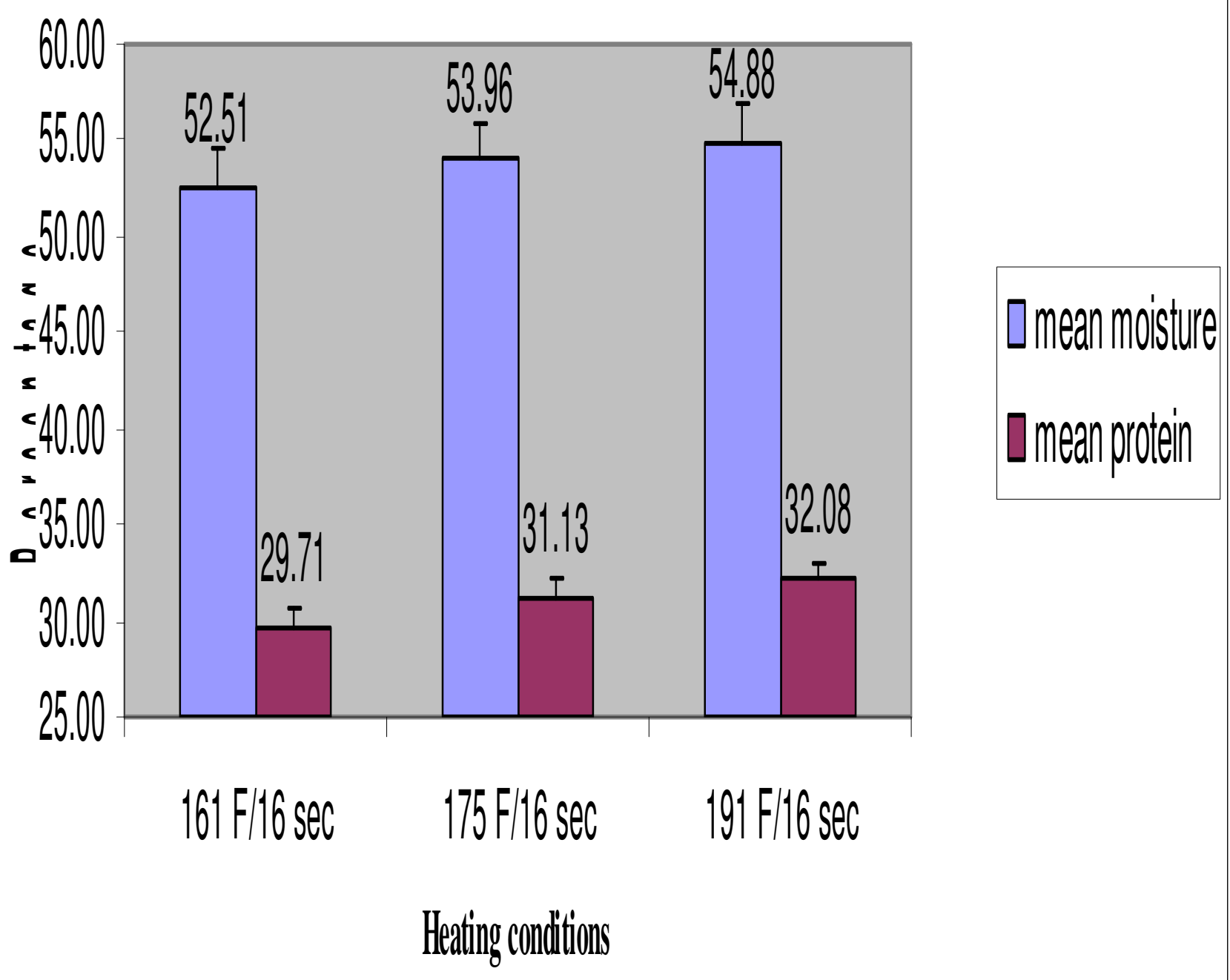

Figure 5.1 Effect of heating conditions on mean moisture and mean protein(+1 Standard Error) of HPDF (with sample size $n=2$ ) 


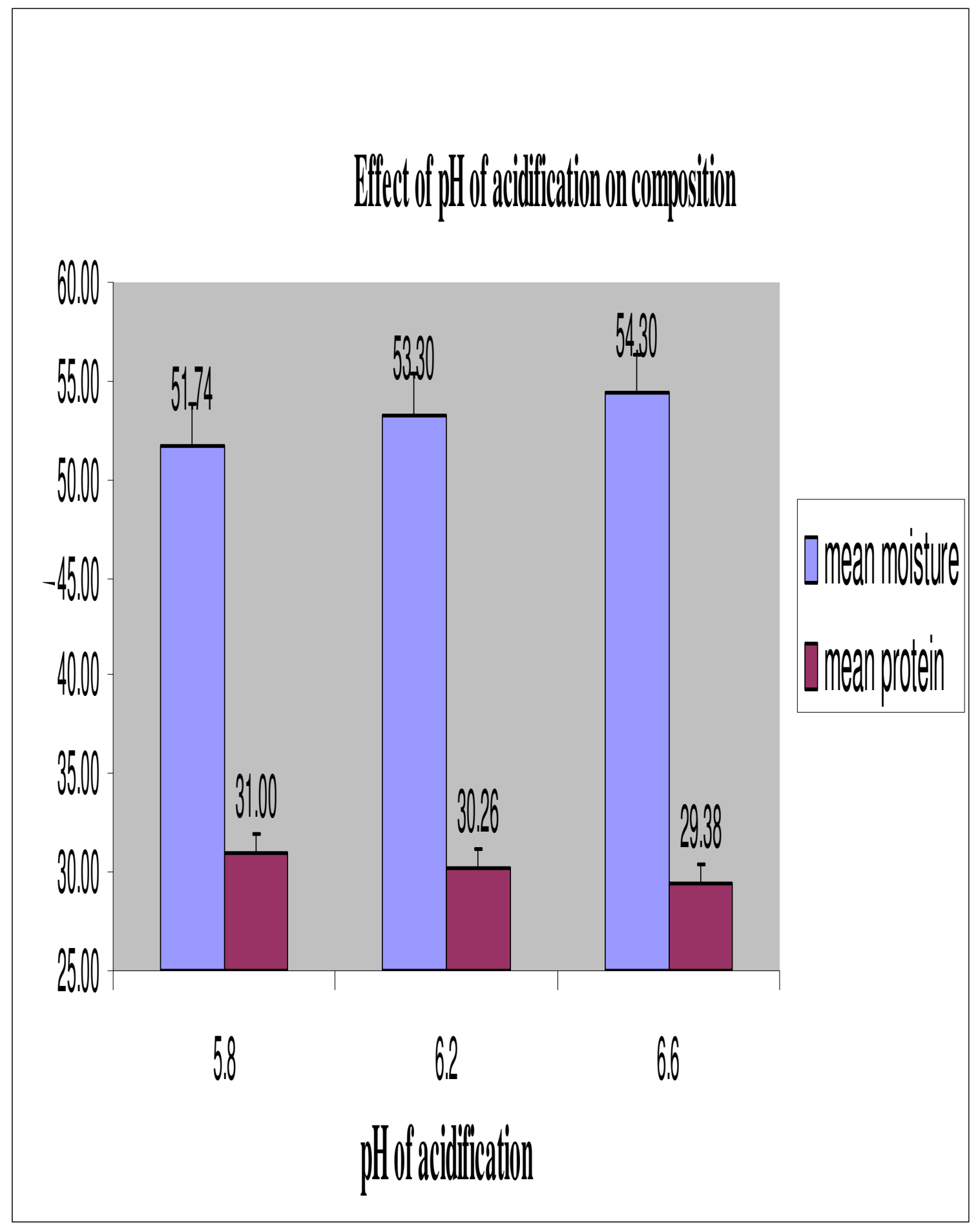

Figure 5.2 Effect of $\mathrm{pH}$ of acidification on mean moisture and mean protein (+1 Standard Error) of HPDF (for sample size $n=2$ ) 


\section{Effect of homogenization on composition}

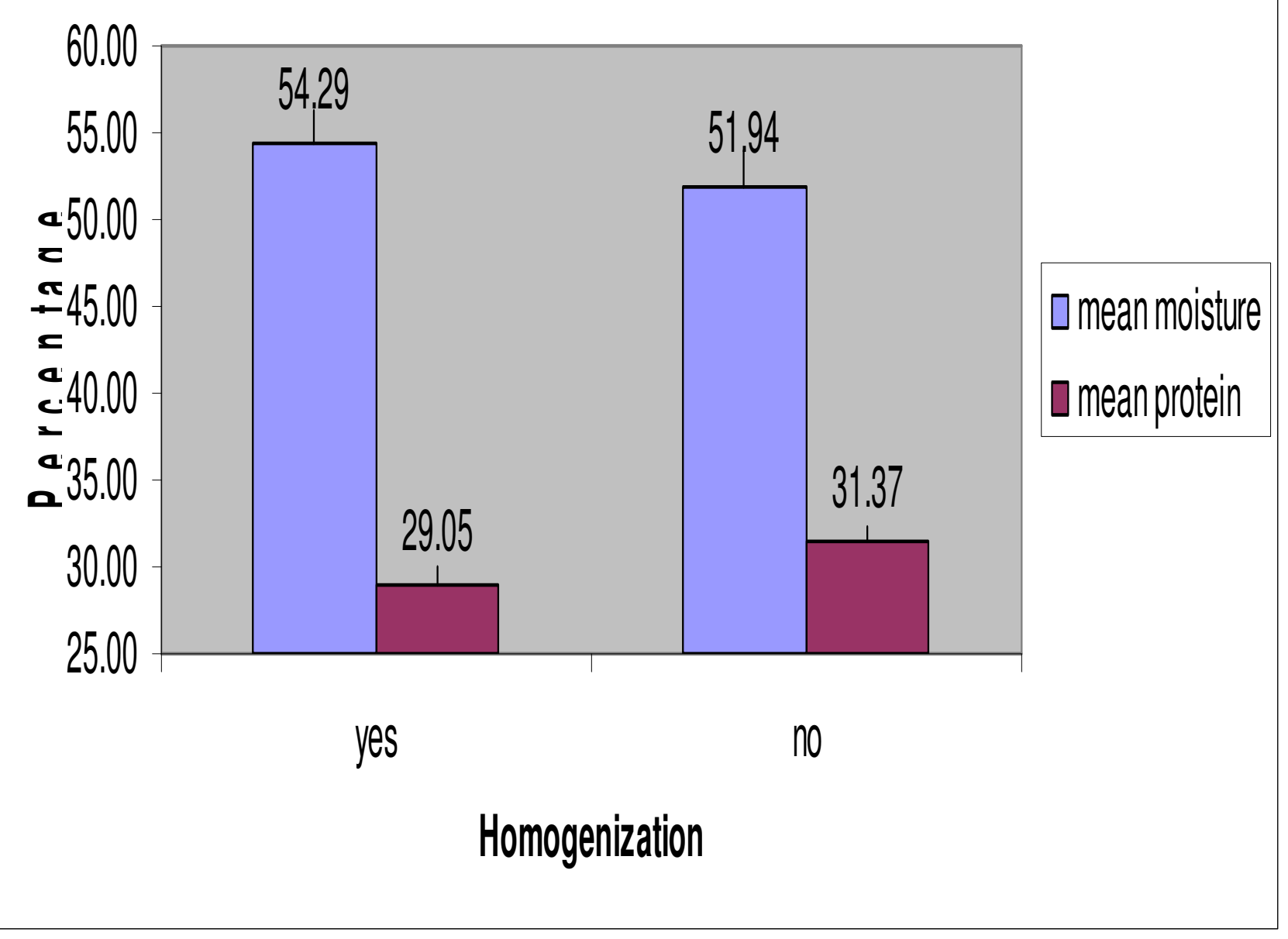

Figure 5.3 Effect of homogenization on mean moisture and mean protein (+1 Standard Error) of HPDF (sample size $n=2$ ) 


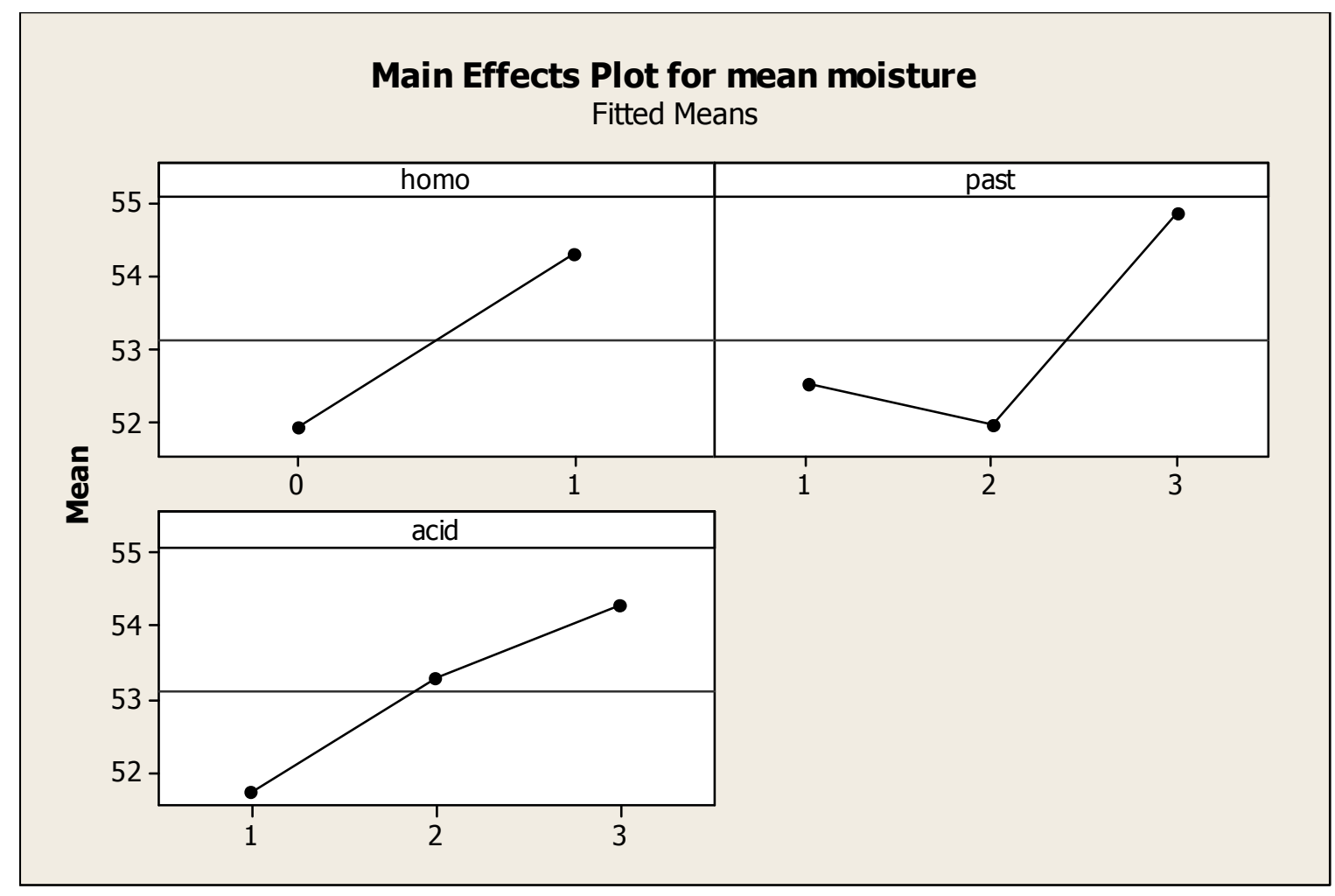

Figure 5.4 Main effects plots for mean moisture vs. pasteurization condition, homogenization and $\mathrm{pH}$ of acidification

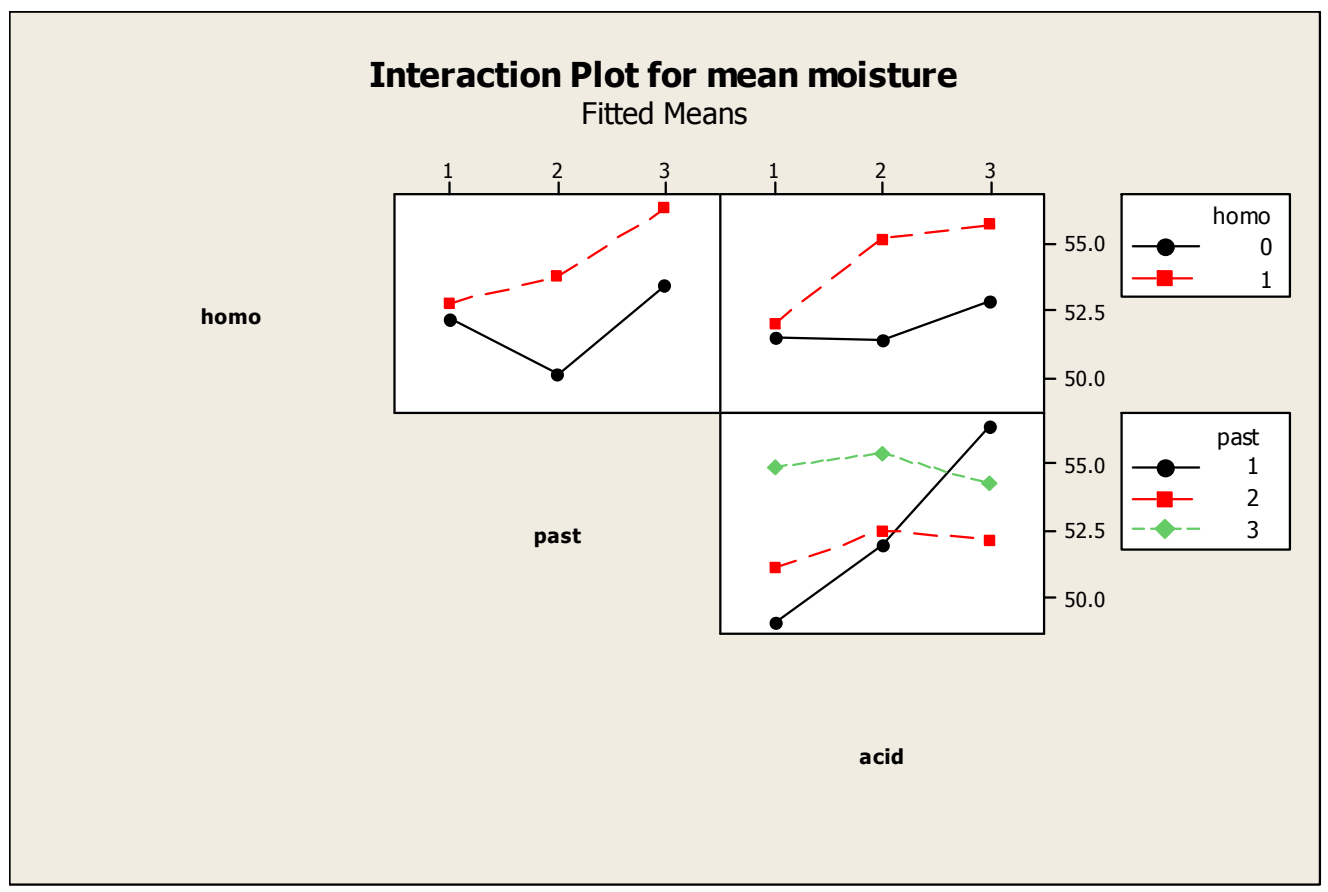

Figure 5.5 Interaction plot for mean moisture vs. pasteurization condition, homogenization and $\mathrm{pH}$ of acidification 


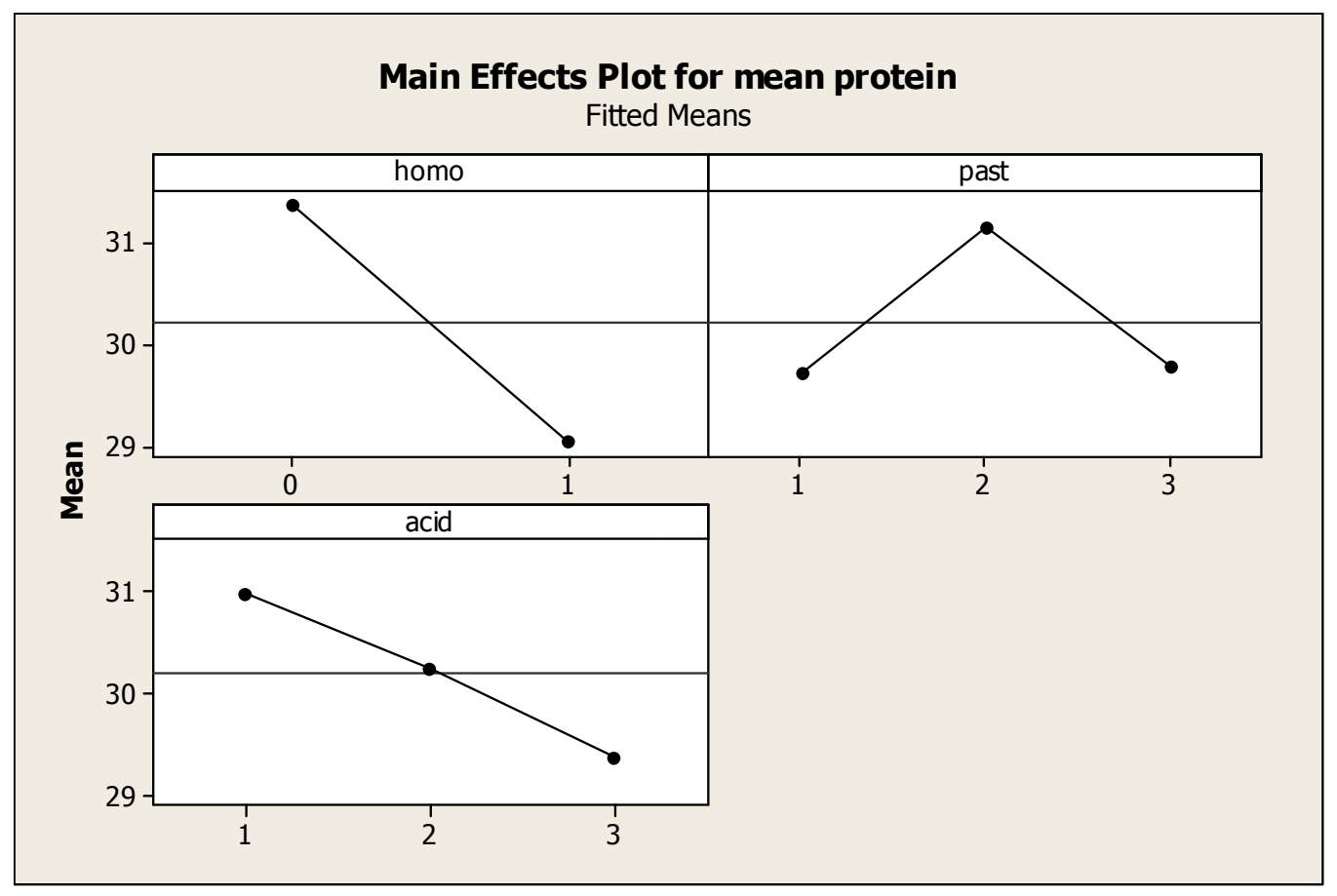

Figure 5.6 Main effects plot for mean protein vs. homogenization, pasteurization and $\mathrm{pH}$ of acidification

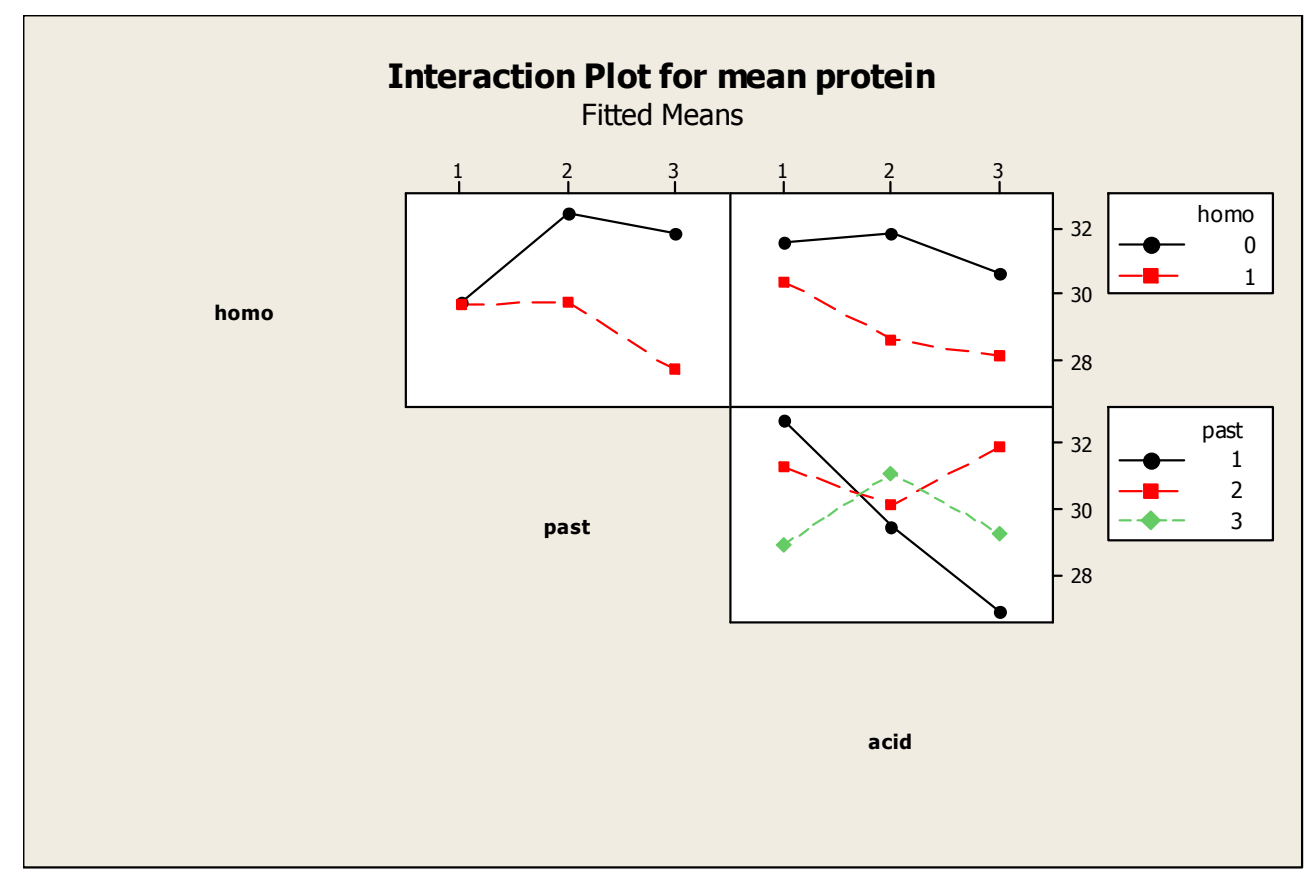

Figure 5.7 Interaction plot for mean protein homogenization, pasteurization and $\mathrm{pH}$ of acidification 


\subsubsection{Analysis of flow properties}

The HPDF (HPDF) was analyzed for flow properties under different heating conditions as described in section 4.5.3. The 'flow unit' obtained after heat treatment under microwave, oven and hot water are presented in Table 5.5, 5.6 and 5.7. The corresponding graphs are presented in Figure 5.8, 5.9 and 5.10.

From Figure 5.8, it is clear that flowability of HPDF decreases as the temperature of heating increases. The flow unit is least when the milk was heated at $191^{\circ} \mathrm{F}\left(88.3^{\circ} \mathrm{C}\right)$ for 16 seconds and the highest when the milk was heated at $161^{\circ} \mathrm{F}\left(71.7^{\circ} \mathrm{C}\right)$ for 16 seconds. The corresponding $\mathrm{p}$ - values (Table 5.8) associated with heat treatment (pasteurization) makes it clear that heating condition is significant for flow properties of HPDF under oven, microwave and hot water. Heat treatment as high as $191^{\circ} \mathrm{F}\left(88.3^{\circ} \mathrm{C}\right)$ for $16 \mathrm{sec}$ denatures as high as $65 \%$ of total whey protein (Fox et al., 1981). The high heat treatment is conducive to formation of thermally-induced $\kappa$-casein/ $\beta$-lactoglobulin complex via disulphide-thiol group. It is likely that on setting, the fused network impede the flow as the fat phase flows and coalesces (Sood and Kosikowski, 1979).

From Figure 5.9 and Table 5.5, 5.6 and 5.7, there appears to be increase in flow of HPDF under all three types of heating as the $\mathrm{pH}$ of HPDF increases, although there is no statistical evidence that $\mathrm{pH}$ of acidification affects the flow properties of the food (Table 5.8). This is consistent with some of the studies $\mathrm{pH}$ is not the singular dominant factor affecting flowability, but $\mathrm{pH}$ is a major factor along with FDM in affecting flow properties (Olson et al., 1998).

From Figure 5.10, homogenization restricts flow properties of HPDF, although this is not supported by statistical evidence (Table 5.8). Homogenization is believed to create a new fat-water interface predominantly containing casein that can make fat globules more stable. The size of fat 
globules and their distribution in the casein matrix influence flow properties and free-oil formation (Jana and Upadhyay, 1992).

The tukey $95 \%$ simultaneous confidence intervals response for mean flowing on heating condition indicates mean flowing (of HPDF) is significantly lower for the food that is made from milk pasteurized at $191^{\circ} \mathrm{F}\left(88.3^{\circ} \mathrm{C}\right)$ for 16 seconds than that of pasteurized at $161^{\circ} \mathrm{F}\left(71.7^{\circ} \mathrm{C}\right)$ for 16 seconds. 
Table 5.5 Mean flowing oven of HPDF under different processing conditions (for sample size $\mathrm{n}=4,1$ flow unit $=10 \mathrm{~mm}$ flow, flow unit $<1$ is considered as flow resistance)

\begin{tabular}{|c|c|c|c|c|c|}
\hline batch & $\begin{array}{l}\mathrm{pH} \text { of } \\
\text { acidification }\end{array}$ & $\begin{array}{l}\text { pasteurization } \\
\text { condition }\end{array}$ & homogenization & $\begin{array}{l}\text { mean flow } \\
\text { unit oven }\end{array}$ & $\begin{array}{c}\text { standard } \\
\text { error }\end{array}$ \\
\hline 1 & 6.6 & $161^{\circ} \mathrm{F} / 16 \mathrm{sec}$ & yes & 4.75 & 0.50 \\
\hline 2 & 5.8 & $191^{0} \mathrm{~F} / 16 \mathrm{sec}$ & no & 0 & 0.00 \\
\hline 3 & 5.8 & $175^{\circ} \mathrm{F} / 16 \mathrm{sec}$ & no & 5 & 0.82 \\
\hline 4 & 6.2 & $175^{\circ} \mathrm{F} / 16 \mathrm{sec}$ & no & 3 & 0.82 \\
\hline 5 & 5.8 & $175^{\circ} \mathrm{F} / 16 \mathrm{sec}$ & yes & 2.25 & 0.96 \\
\hline 6 & 6.2 & $191^{\circ} \mathrm{F} / 16 \mathrm{sec}$ & no & 0.5 & 0.58 \\
\hline 7 & 5.8 & $191^{0} \mathrm{~F} / 16 \mathrm{sec}$ & yes & 0 & 0.00 \\
\hline 8 & 6.2 & $175^{\circ} \mathrm{F} / 16 \mathrm{sec}$ & yes & 1 & 0.00 \\
\hline 9 & 6.2 & $161^{\circ} \mathrm{F} / 16 \mathrm{sec}$ & yes & 7.75 & 0.50 \\
\hline 10 & 5.8 & $161^{0} \mathrm{~F} / 16 \mathrm{sec}$ & yes & 2.25 & 0.50 \\
\hline 11 & 6.6 & $175^{\circ} \mathrm{F} / 16 \mathrm{sec}$ & no & 4 & 0.82 \\
\hline 12 & 6.2 & $191^{0} \mathrm{~F} / 16 \mathrm{sec}$ & yes & 0.25 & 0.50 \\
\hline 13 & 6.6 & $191^{\circ} \mathrm{F} / 16 \mathrm{sec}$ & no & 2.25 & 0.96 \\
\hline 14 & 6.6 & $175^{\circ} \mathrm{F} / 16 \mathrm{sec}$ & yes & 2.25 & 0.50 \\
\hline 15 & 6.6 & $191^{\circ} \mathrm{F} / 16 \mathrm{sec}$ & yes & 2.25 & 0.96 \\
\hline 16 & 6.6 & $161^{\circ} \mathrm{F} / 16 \mathrm{sec}$ & no & 8 & 0.00 \\
\hline 17 & 6.2 & $161^{0} \mathrm{~F} / 16 \mathrm{sec}$ & no & 4 & 0.00 \\
\hline 18 & 5.8 & $161^{\circ} \mathrm{F} / 16 \mathrm{sec}$ & no & 3.25 & 0.50 \\
\hline
\end{tabular}


Table 5.6 Mean flowing microwave of HPDF under different processing conditions (for sample size $\mathrm{n}=4,1$ flow unit $=10 \mathrm{~mm}$ flow, flow unit $<1$ is considered as flow resistance)

\begin{tabular}{|c|c|c|c|c|c|}
\hline Batch & $\begin{array}{c}\mathrm{pH} \text { of } \\
\text { acidification }\end{array}$ & $\begin{array}{l}\text { Heating } \\
\text { condition }\end{array}$ & homogenization & $\begin{array}{l}\text { Mean flow } \\
\text { unit } \\
\text { microwave }\end{array}$ & $\begin{array}{c}\text { standard } \\
\text { error }\end{array}$ \\
\hline 1 & 6.6 & $161^{\circ} \mathrm{F} / 16 \mathrm{sec}$ & yes & 6 & 0.00 \\
\hline 2 & 5.8 & $191^{\circ} \mathrm{F} / 16 \mathrm{sec}$ & no & 0.25 & 0.50 \\
\hline 3 & 5.8 & $175^{\circ} \mathrm{F} / 16 \mathrm{sec}$ & no & 4 & 0.82 \\
\hline 4 & 6.2 & $175^{\circ} \mathrm{F} / 16 \mathrm{sec}$ & no & 3.75 & 0.50 \\
\hline 5 & 5.8 & $175^{\circ} \mathrm{F} / 16 \mathrm{sec}$ & yes & 4 & 0.82 \\
\hline 6 & 6.2 & $191^{\circ} \mathrm{F} / 16 \mathrm{sec}$ & no & 0.25 & 0.50 \\
\hline 7 & 5.8 & $191^{\circ} \mathrm{F} / 16 \mathrm{sec}$ & yes & 0 & 0.00 \\
\hline 8 & 6.2 & $175^{\circ} \mathrm{F} / 16 \mathrm{sec}$ & yes & 2.5 & 0.58 \\
\hline 9 & 6.2 & $161^{\circ} \mathrm{F} / 16 \mathrm{sec}$ & yes & 9 & 0.00 \\
\hline 10 & 5.8 & $161^{\circ} \mathrm{F} / 16 \mathrm{sec}$ & yes & 5 & 0.00 \\
\hline 11 & 6.6 & $175^{\circ} \mathrm{F} / 16 \mathrm{sec}$ & no & 3.75 & 0.50 \\
\hline 12 & 6.2 & $191^{\circ} \mathrm{F} / 16 \mathrm{sec}$ & yes & 0.5 & 0.58 \\
\hline 13 & 6.6 & $191^{\circ} \mathrm{F} / 16 \mathrm{sec}$ & no & 5.75 & 0.96 \\
\hline 14 & 6.6 & $175^{\circ} \mathrm{F} / 16 \mathrm{sec}$ & yes & 9 & 0.00 \\
\hline 15 & 6.6 & $191^{\circ} \mathrm{F} / 16 \mathrm{sec}$ & yes & 1.75 & 0.50 \\
\hline 16 & 6.6 & $161^{\circ} \mathrm{F} / 16 \mathrm{sec}$ & no & 9 & 0.00 \\
\hline 17 & 6.2 & $161^{\circ} \mathrm{F} / 16 \mathrm{sec}$ & no & 9 & 0.00 \\
\hline 18 & 5.8 & $161^{\circ} \mathrm{F} / 16 \mathrm{sec}$ & no & 9 & 0.00 \\
\hline
\end{tabular}


Table 5.7 Mean flowing of HPDF in hot water under different processing conditions (for sample size $\mathrm{n}=4,1$ flow unit $=10 \mathrm{~mm}$ flow, flow unit $<1$ is considered as flow resistance)

\begin{tabular}{|c|c|c|c|c|c|}
\hline Batch & $\begin{array}{c}\mathrm{pH} \text { of } \\
\text { acidification }\end{array}$ & $\begin{array}{l}\text { heating } \\
\text { condition }\end{array}$ & homogenization & $\begin{array}{c}\text { Mean flow } \\
\text { unit hot } \\
\text { water }\end{array}$ & $\begin{array}{c}\text { Standard } \\
\text { error }\end{array}$ \\
\hline 1 & 6.6 & $161^{\circ} \mathrm{F} / 16 \mathrm{sec}$ & yes & 2.75 & 0.50 \\
\hline 2 & 5.8 & $191^{\circ} \mathrm{F} / 16 \mathrm{sec}$ & no & 0 & 0.00 \\
\hline 3 & 5.8 & $175^{\circ} \mathrm{F} / 16 \mathrm{sec}$ & no & 3.75 & 0.50 \\
\hline 4 & 6.2 & $175^{\circ} \mathrm{F} / 16 \mathrm{sec}$ & no & 3.75 & 0.50 \\
\hline 5 & 5.8 & $175^{\circ} \mathrm{F} / 16 \mathrm{sec}$ & yes & 2.75 & 0.50 \\
\hline 6 & 6.2 & $191^{\circ} \mathrm{F} / 16 \mathrm{sec}$ & no & 0.25 & 0.50 \\
\hline 7 & 5.8 & $191^{\circ} \mathrm{F} / 16 \mathrm{sec}$ & yes & 0.25 & 0.50 \\
\hline 8 & 6.2 & $175^{\circ} \mathrm{F} / 16 \mathrm{sec}$ & yes & 1 & 0.00 \\
\hline 9 & 6.2 & $161^{\circ} \mathrm{F} / 16 \mathrm{sec}$ & yes & 7.25 & 0.50 \\
\hline 10 & 5.8 & $161^{\circ} \mathrm{F} / 16 \mathrm{sec}$ & yes & 4.25 & 0.50 \\
\hline 11 & 6.6 & $175^{\circ} \mathrm{F} / 16 \mathrm{sec}$ & no & 2.75 & 0.50 \\
\hline 12 & 6.2 & $191^{\circ} \mathrm{F} / 16 \mathrm{sec}$ & yes & 0.25 & 0.50 \\
\hline 13 & 6.6 & $191^{\circ} \mathrm{F} / 16 \mathrm{sec}$ & no & 3.25 & 0.96 \\
\hline 14 & 6.6 & $175^{\circ} \mathrm{F} / 16 \mathrm{sec}$ & yes & 3.5 & 0.58 \\
\hline 15 & 6.6 & $191^{\circ} \mathrm{F} / 16 \mathrm{sec}$ & yes & 1.5 & 0.58 \\
\hline 16 & 6.6 & $161^{\circ} \mathrm{F} / 16 \mathrm{sec}$ & no & 7.25 & 0.50 \\
\hline 17 & 6.2 & $161^{\circ} \mathrm{F} / 16 \mathrm{sec}$ & No & 4.75 & 0.96 \\
\hline 18 & 5.8 & $161^{\circ} \mathrm{F} / 16 \mathrm{sec}$ & No & 3.25 & 0.50 \\
\hline
\end{tabular}


Table 5.8 p-values of test of significance of mean flowing in oven, hot water and microwave at different acidification, pasteurization and homogenization levels. (1 flow unit=10 $\mathrm{mm}$ flow)

\begin{tabular}{|c|c|c|c|}
\hline Factors & $\begin{array}{c}\text { Mean flow unit } \\
\text { in oven }\end{array}$ & $\begin{array}{c}\text { Mean flow unit in } \\
\text { hot water }\end{array}$ & $\begin{array}{c}\text { Mean flow unit in } \\
\text { microwave }\end{array}$ \\
\hline Acidification & 0.229 & 0.626 & 0.324 \\
\hline Pasteurization & $\mathbf{0 . 0 2 3}$ & 0.054 & $\mathbf{0 . 0 2 1}$ \\
\hline Homogenization & 0.32 & 0.533 & 0.508 \\
\hline Acid*past & 0.341 & 0.688 & 0.586 \\
\hline Acid*homo & 0.47 & 0.952 & 0.432 \\
\hline Past*homo & 0.485 & 0.657 & 0.913 \\
\hline
\end{tabular}




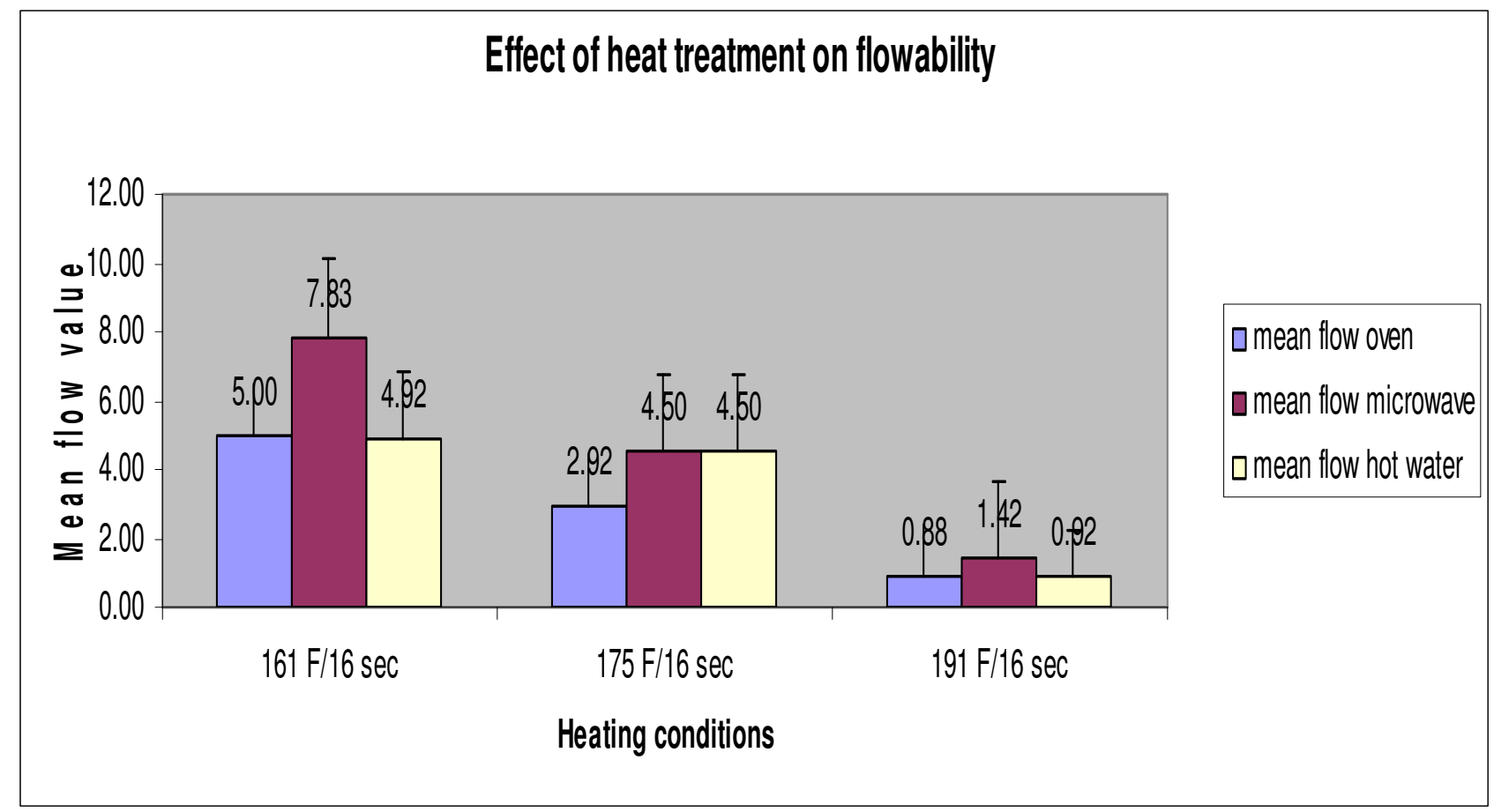

Figure 5.8 Effect of heating conditions on flowing under oven, microwave and hot water $(+1$ Standard Error, $n=4)$ 


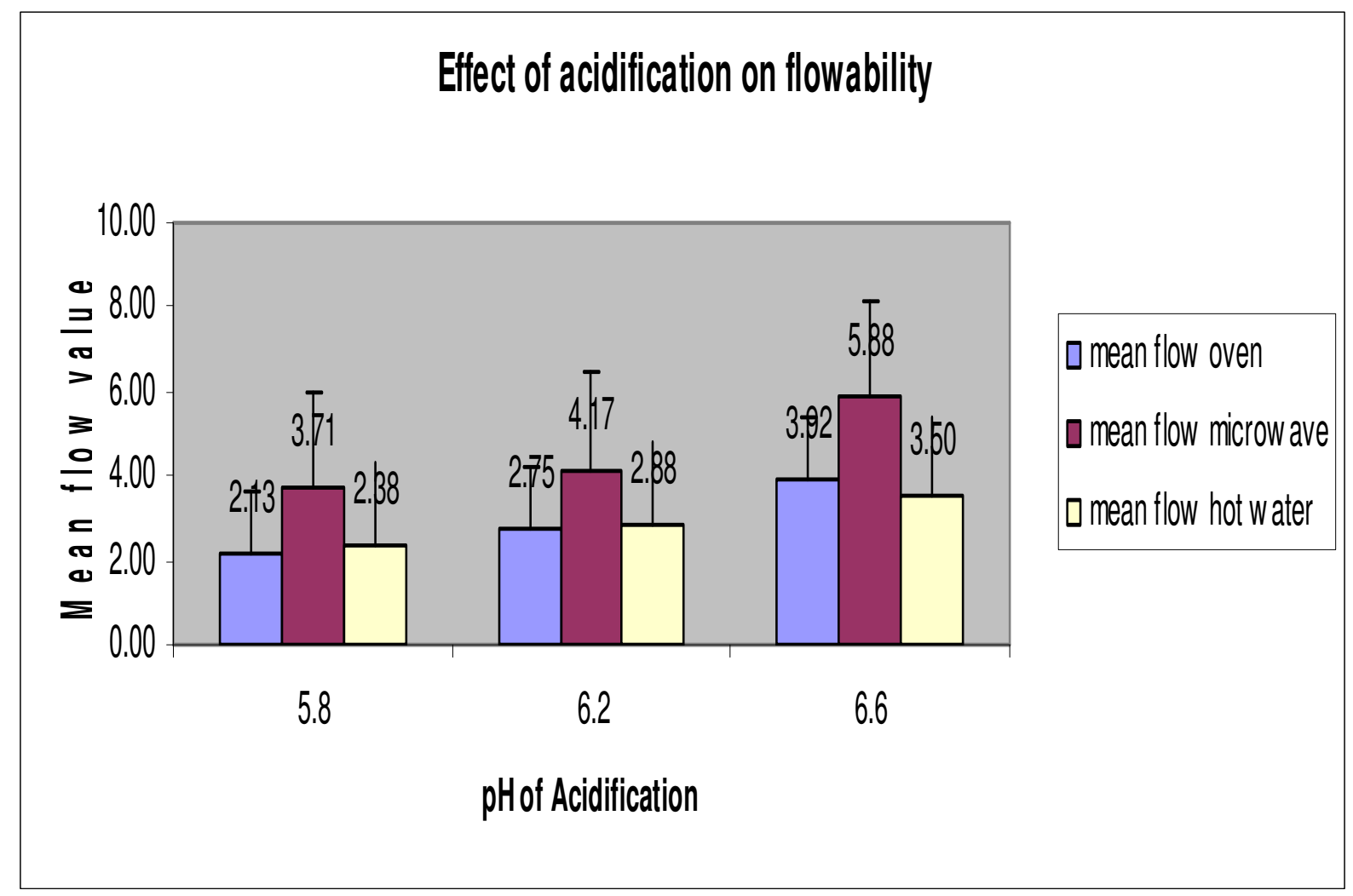

Figure 5.9 Effect of acidification on flowing under oven, microwave and hot water (for +1 Standard Error, $n=4$ ) 


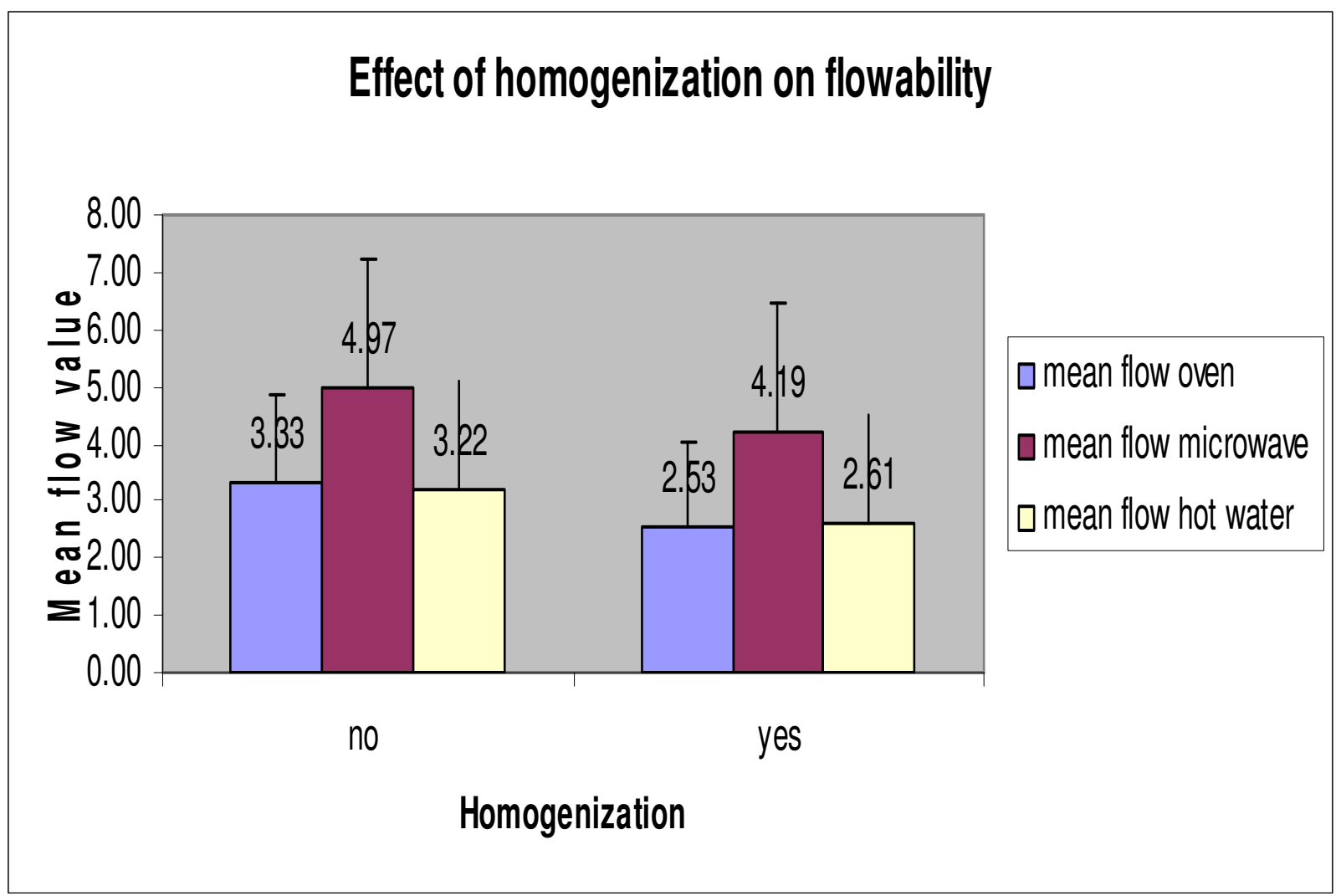

Figure 5.10 Effect of homogenization on flowing under oven, microwave and hot water (for +1 Standard Error, $n=4$ ) 


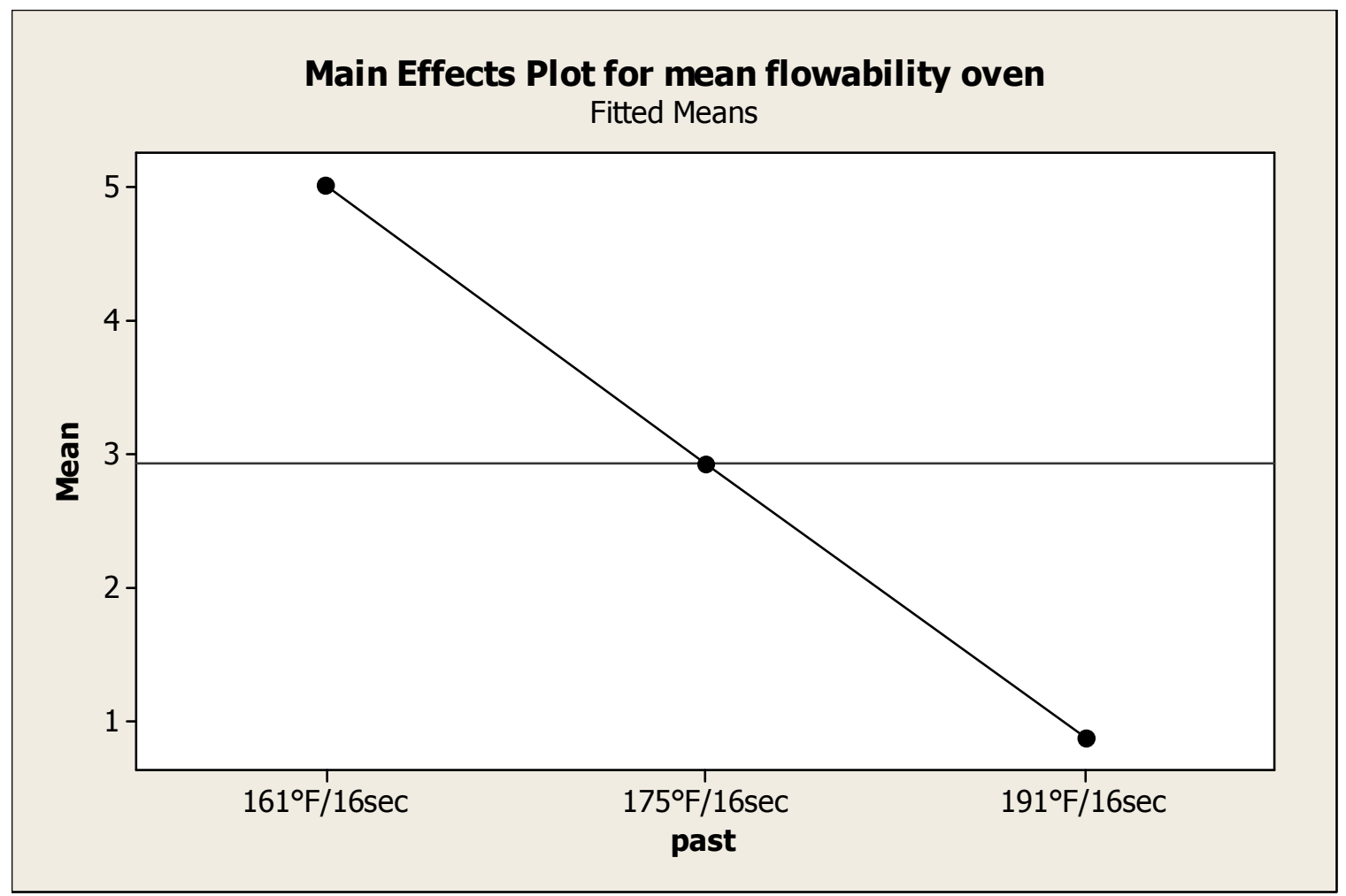

Figure 5.11 Main Effects plot for mean flowability in oven vs. pasteurization

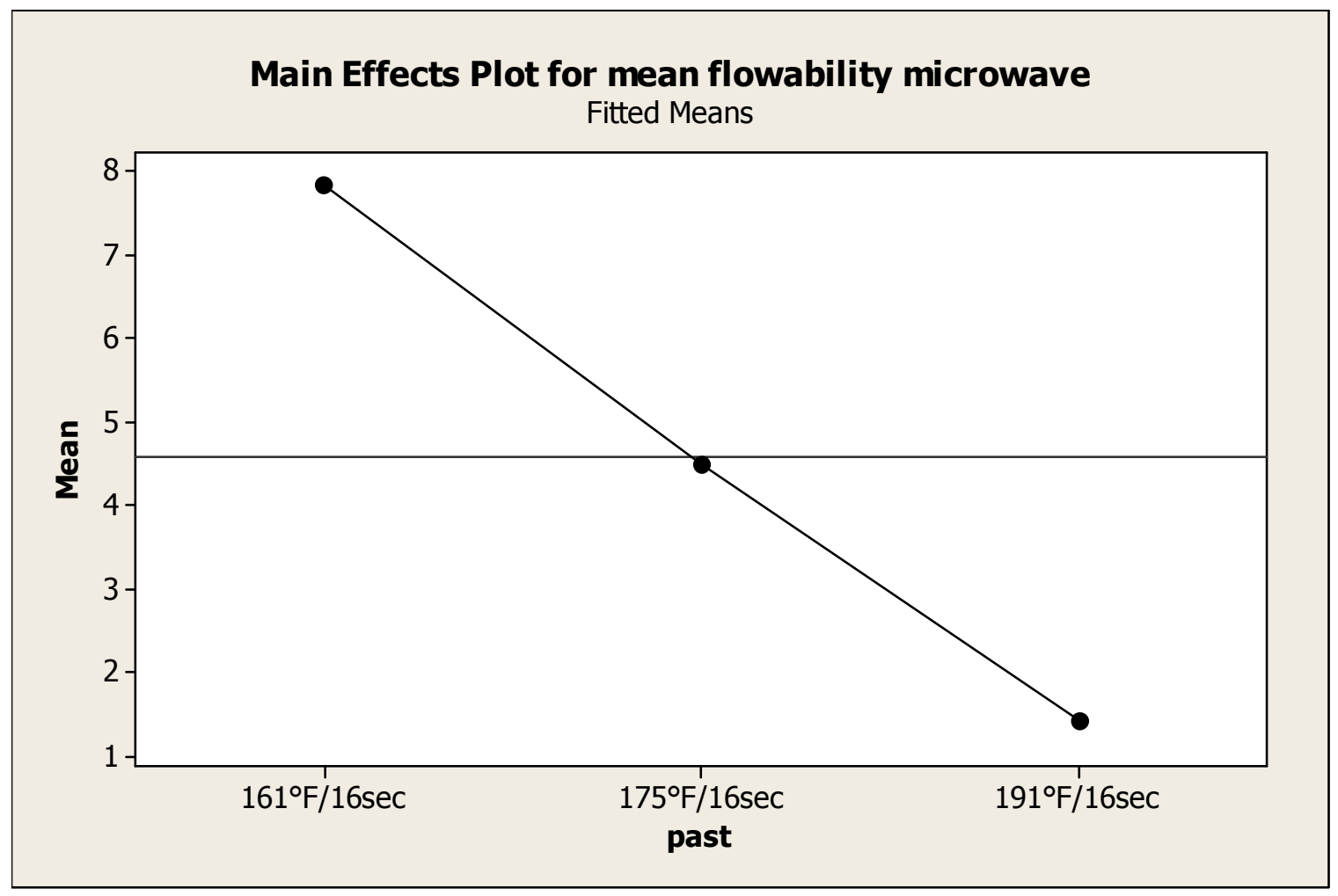

Figure 5.12 Main Effects plot for mean flowability in microwave vs. pasteurization 


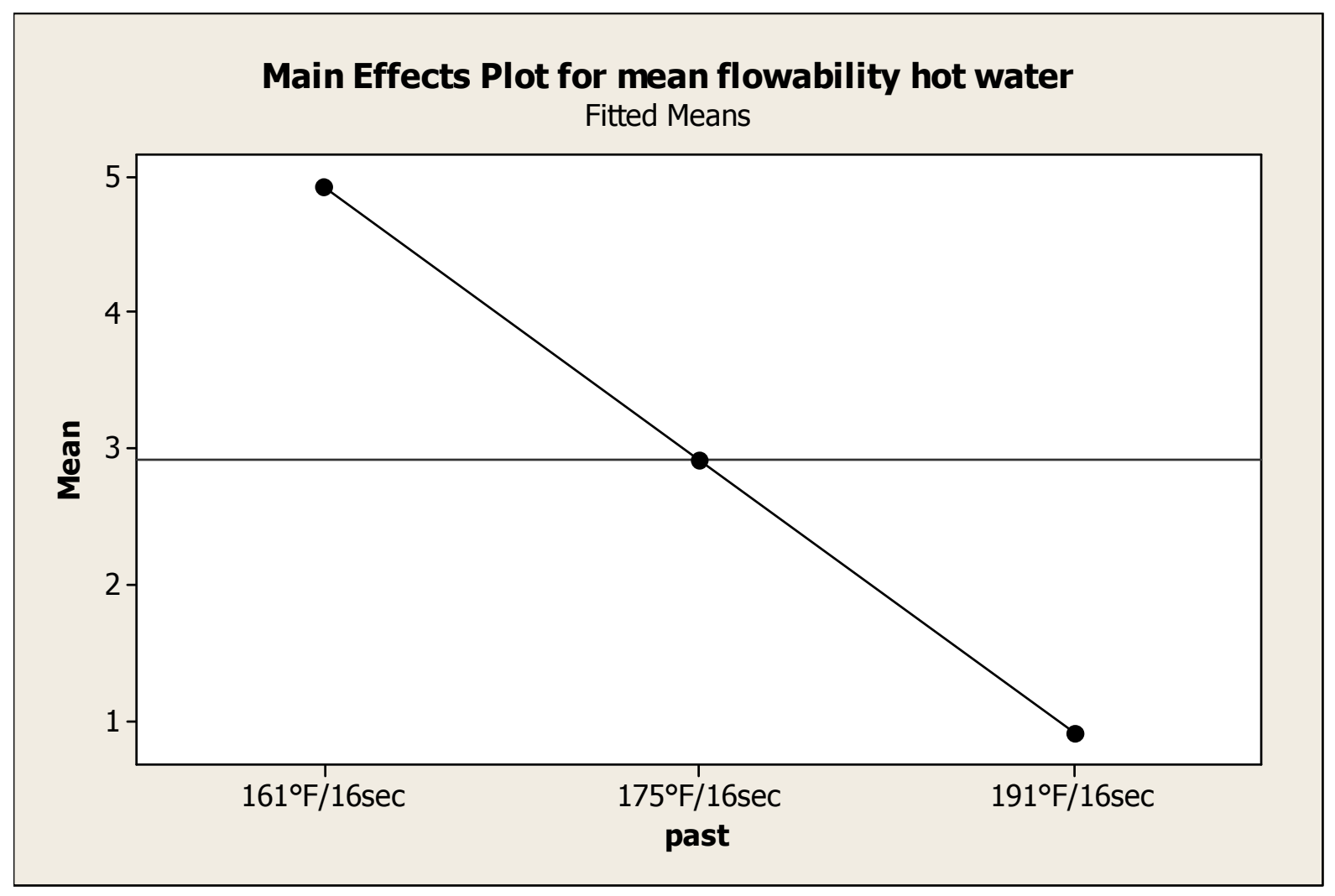

Figure 5.13 Main Effects plot for mean flowability in hot water vs. pasteurization 


\subsubsection{Analysis of textural properties}

From Figure 5.14 and Table 5.16, it is clear that hardness of HPDF increases with increase in pasteurization temperature. This can be explained by loss of moisture in the HPDF during higher level of heat treatment. It is well established that higher moisture content food, at a give $\mathrm{pH}$ are less firm than their lower-moisture content counter parts. This has been attributed to the extent of swelling of casein submicelles with the increase in casein-to-moisture ratio. The same theory applies to the effect of homogenization on hardness of HPDF. Homogenization leads to higher moisture content (as observed in 5.2.1) and hence the hardness of HPDF decreases (Figure 5.18). $\mathrm{pH}$ of acidification plays an important role in determining the ratio of soluble-to-miceller calcium (Kosikowski, 1977). As the $\mathrm{pH}$ of acidification decreases, the colloidal calcium migrates to serum phase, becomes soluble and eventually is lost in whey during syneresis. Low acidity (high pH) weakens the protein bonds through charge repulsion, as the negative charges on casein molecules increase with $\mathrm{pH}$. The hydrophobic interactions, important for a stable casein matrix structure, are weakened by adsorption of water by proteins to solvate the ionic charges. These factors together contribute to the increase in hardness of HPDF with decrease in $\mathrm{pH}$.

Although the p-values associated with homogenization and acidification (as individual factor) are less significant $(>0.05)$ for hardness, the interaction $p$-value for acidification and pasteurization condition are still significant (Table 5.18). Also, the interaction p-value for acidification and pasteurization condition suggests that there is a significant interaction. Thus, effect of each of these factors on hardness of HPDF is dependent on each other.

Also, effect of pasteurization condition is significant for gumminess of HPDF.

Gumminess is defined as energy required for disintegration of food until it is ready for swallowing (Bourne, 1968). It is a product of hardness and cohesiveness. All the factors, which are significant 
for hardness of HPDF, are also significant for gumminess (Table 5.11) probably because of the same reasons discussed above.

None of the three factors are significant for cohesiveness, springiness and chewiness of HPDF (Table 5.11) in this experiment. Therefore, the effect of these factors is investigated further in next stages of experiments with duplicate. 
Table 5.9 Effect of processing parameter on mean hardness, mean gumminess and mean chewiness of HPDF (for sample size $\mathrm{N}=3$ )

\begin{tabular}{|c|c|c|c|c|c|c|}
\hline Batch & $\begin{array}{l}\mathrm{pH} \text { of } \\
\text { acidification }\end{array}$ & $\begin{array}{l}\text { pasteurization } \\
\text { condition }\end{array}$ & Homogenization & $\begin{array}{c}\text { Mean } \\
\text { hardness } \\
\text { (g) }\end{array}$ & $\begin{array}{c}\text { Mean } \\
\text { gumminess } \\
\text { (g) }\end{array}$ & $\begin{array}{c}\text { Mean } \\
\text { chewiness } \\
\text { (J) }\end{array}$ \\
\hline 1 & 6.6 & $161^{\circ} \mathrm{F} / 16 \mathrm{sec}$ & Yes & 844.08 & 504.63 & 1045.09 \\
\hline 2 & 5.8 & $191^{\circ} \mathrm{F} / 16 \mathrm{sec}$ & No & 2863.13 & 1750.64 & 5060.56 \\
\hline 3 & 5.8 & $175^{\circ} \mathrm{F} / 16 \mathrm{sec}$ & No & 2317.53 & 1486.07 & 7818.98 \\
\hline 4 & 6.2 & $175^{\circ} \mathrm{F} / 16 \mathrm{sec}$ & No & 1141.69 & 706.19 & 2963.64 \\
\hline 5 & 5.8 & $175^{\circ} \mathrm{F} / 16 \mathrm{sec}$ & Yes & 2502.41 & 1500.53 & 4882.84 \\
\hline 6 & 6.2 & $191^{0} \mathrm{~F} / 16 \mathrm{sec}$ & No & 3314.32 & 2208.99 & 6453.75 \\
\hline 7 & 5.8 & $191^{\circ} \mathrm{F} / 16 \mathrm{sec}$ & Yes & 2512.19 & 1654.19 & 4984.92 \\
\hline 8 & 6.2 & $175^{\circ} \mathrm{F} / 16 \mathrm{sec}$ & Yes & 2389.84 & 1295.97 & 5737.75 \\
\hline 9 & 6.2 & $161^{0} \mathrm{~F} / 16 \mathrm{sec}$ & Yes & 2160.07 & 1358.97 & 4992.62 \\
\hline 10 & 5.8 & $161^{0} \mathrm{~F} / 16 \mathrm{sec}$ & Yes & 1747.45 & 932.76 & 3384.84 \\
\hline 11 & 6.6 & $175^{\circ} \mathrm{F} / 16 \mathrm{sec}$ & No & 1947.32 & 1278.14 & 4951.42 \\
\hline 12 & 6.2 & $191^{\circ} \mathrm{F} / 16 \mathrm{sec}$ & Yes & 3196.11 & 1667.04 & 4033.32 \\
\hline 13 & 6.6 & $191^{\circ} \mathrm{F} / 16 \mathrm{sec}$ & No & 4206.18 & 2418.98 & 6160.79 \\
\hline 14 & 6.6 & $175^{\circ} \mathrm{F} / 16 \mathrm{sec}$ & Yes & 2449.17 & 1681.05 & 3532.24 \\
\hline 15 & 6.6 & $191^{\circ} \mathrm{F} / 16 \mathrm{sec}$ & Yes & 3781.97 & 2543.15 & 9125.05 \\
\hline 16 & 6.6 & $161^{0} \mathrm{~F} / 16 \mathrm{sec}$ & No & 1174.99 & 701.95 & 1770.16 \\
\hline 17 & 6.2 & $161^{\circ} \mathrm{F} / 16 \mathrm{sec}$ & No & 3941.84 & 2626.11 & 6181.87 \\
\hline 18 & 5.8 & $161^{\circ} \mathrm{F} / 16 \mathrm{sec}$ & No & 2981.49 & 2249.95 & 4902.42 \\
\hline
\end{tabular}


Table 5.10 Effect of processing parameter on mean chewiness and mean springiness of HPDF (for sample size $\mathrm{n}=3$ )

\begin{tabular}{|c|c|c|c|c|c|}
\hline batch & $\begin{array}{c}\mathrm{pH} \text { of } \\
\text { acidification }\end{array}$ & $\begin{array}{l}\text { heating } \\
\text { condition }\end{array}$ & Homogenization & $\begin{array}{c}\text { Mean } \\
\text { cohesiveness }\end{array}$ & $\begin{array}{c}\text { Mean } \\
\text { springiness }\end{array}$ \\
\hline 1 & 6.6 & $161^{\circ} \mathrm{F} / 16 \mathrm{sec}$ & Yes & 0.61 & 2.02 \\
\hline 2 & 5.8 & $191^{\circ} \mathrm{F} / 16 \mathrm{sec}$ & No & 0.61 & 2.93 \\
\hline 3 & 5.8 & $175^{\circ} \mathrm{F} / 16 \mathrm{sec}$ & No & 0.64 & 5.16 \\
\hline 4 & 6.2 & $175^{\circ} \mathrm{F} / 16 \mathrm{sec}$ & No & 0.62 & 4.22 \\
\hline 5 & 5.8 & $175^{\circ} \mathrm{F} / 16 \mathrm{sec}$ & Yes & 0.60 & 3.30 \\
\hline 6 & 6.2 & $191^{\circ} \mathrm{F} / 16 \mathrm{sec}$ & No & 0.67 & 2.91 \\
\hline 7 & 5.8 & $191^{\circ} \mathrm{F} / 16 \mathrm{sec}$ & Yes & 0.66 & 3.05 \\
\hline 8 & 6.2 & $175^{\circ} \mathrm{F} / 16 \mathrm{sec}$ & Yes & 0.54 & 4.40 \\
\hline 9 & 6.2 & $161^{\circ} \mathrm{F} / 16 \mathrm{sec}$ & Yes & 0.63 & 3.65 \\
\hline 10 & 5.8 & $161^{\circ} \mathrm{F} / 16 \mathrm{sec}$ & Yes & 0.53 & 3.66 \\
\hline 11 & 6.6 & $175^{\circ} \mathrm{F} / 16 \mathrm{sec}$ & No & 0.65 & 3.86 \\
\hline 12 & 6.2 & $191^{\circ} \mathrm{F} / 16 \mathrm{sec}$ & Yes & 0.52 & 2.43 \\
\hline 13 & 6.6 & $191^{\circ} \mathrm{F} / 16 \mathrm{sec}$ & No & 0.57 & 2.67 \\
\hline 14 & 6.6 & $175^{\circ} \mathrm{F} / 16 \mathrm{sec}$ & Yes & 0.70 & 2.13 \\
\hline 15 & 6.6 & $191^{\circ} \mathrm{F} / 16 \mathrm{sec}$ & Yes & 0.67 & 3.62 \\
\hline 16 & 6.6 & $161^{\circ} \mathrm{F} / 16 \mathrm{sec}$ & No & 0.61 & 2.53 \\
\hline 17 & 6.2 & $161^{\circ} \mathrm{F} / 16 \mathrm{sec}$ & No & 0.67 & 2.36 \\
\hline 18 & 5.8 & $161^{\circ} \mathrm{F} / 16 \mathrm{sec}$ & No & 0.75 & 2.24 \\
\hline
\end{tabular}




\section{Effect of heating condition on texture}

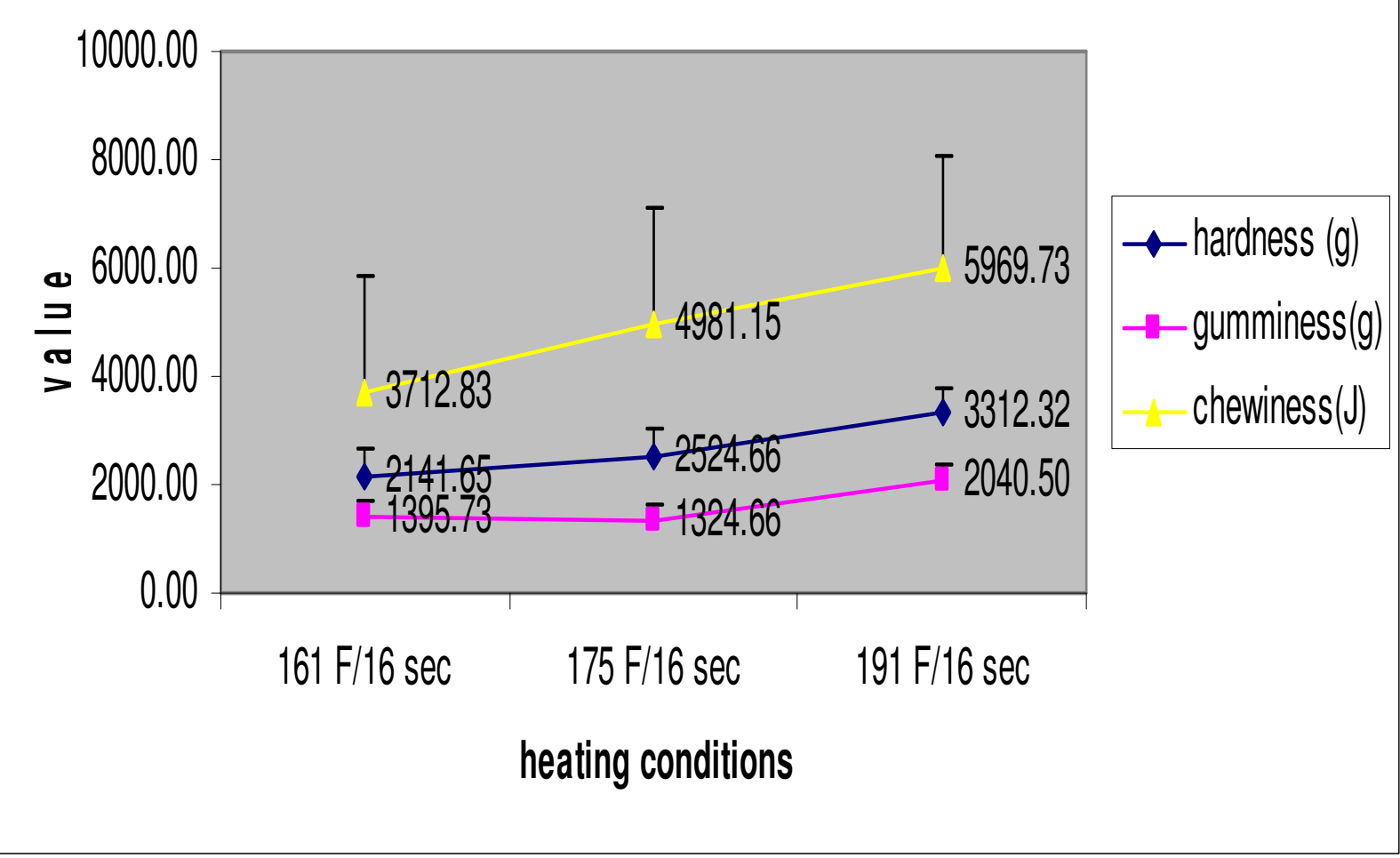

Figure 5.14 Effect of heating condition on hardness, gumminess and chewiness of HPDF (for +1 Standard Error, $n=3$ ) 


\section{Effect of heating condition on texture}

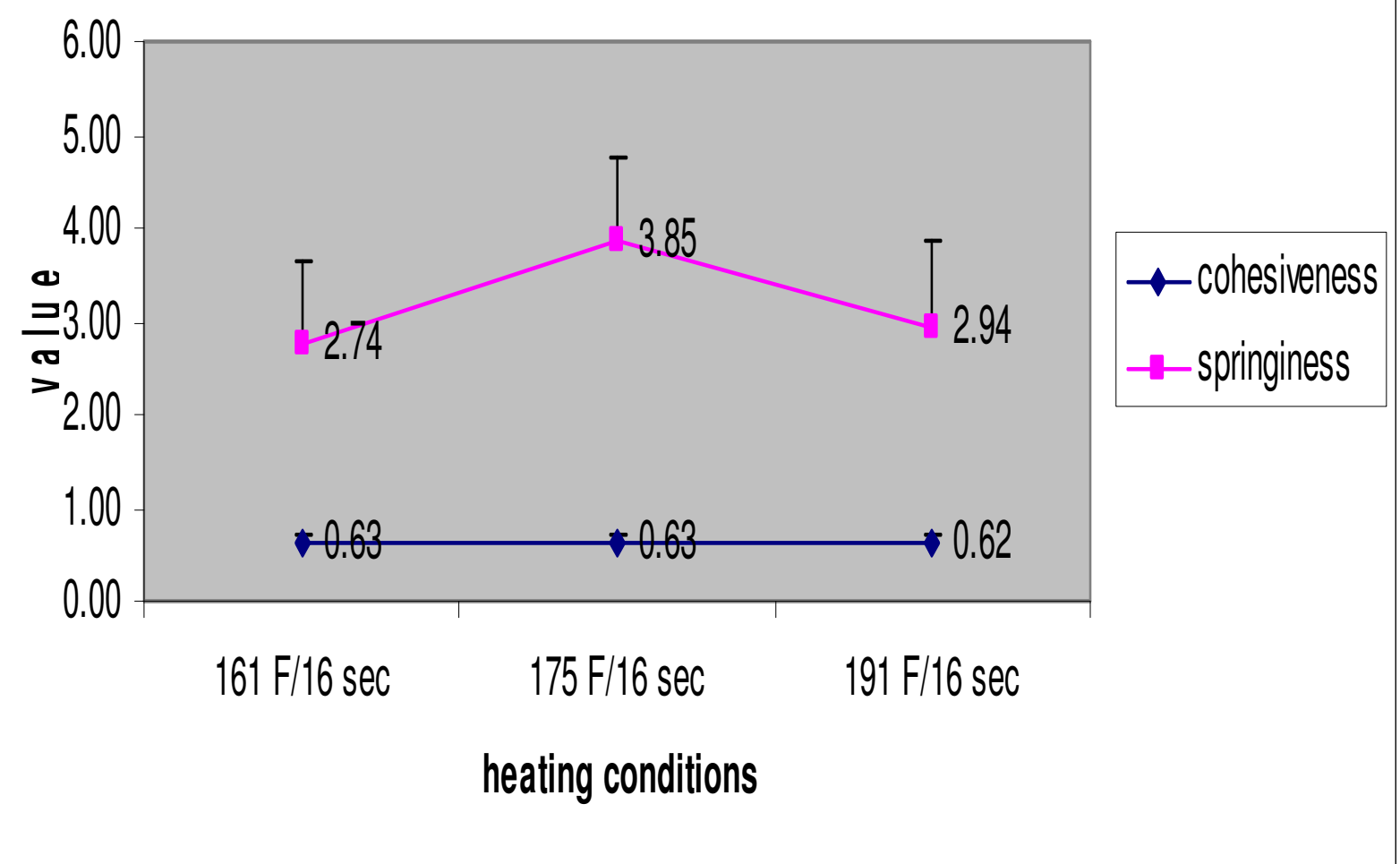

Figure 5.15 Effect of heating condition on cohesiveness and springiness of HPDF (for +1 Standard Error, $n=3$ ) 


\section{Effect of acidification on texture}

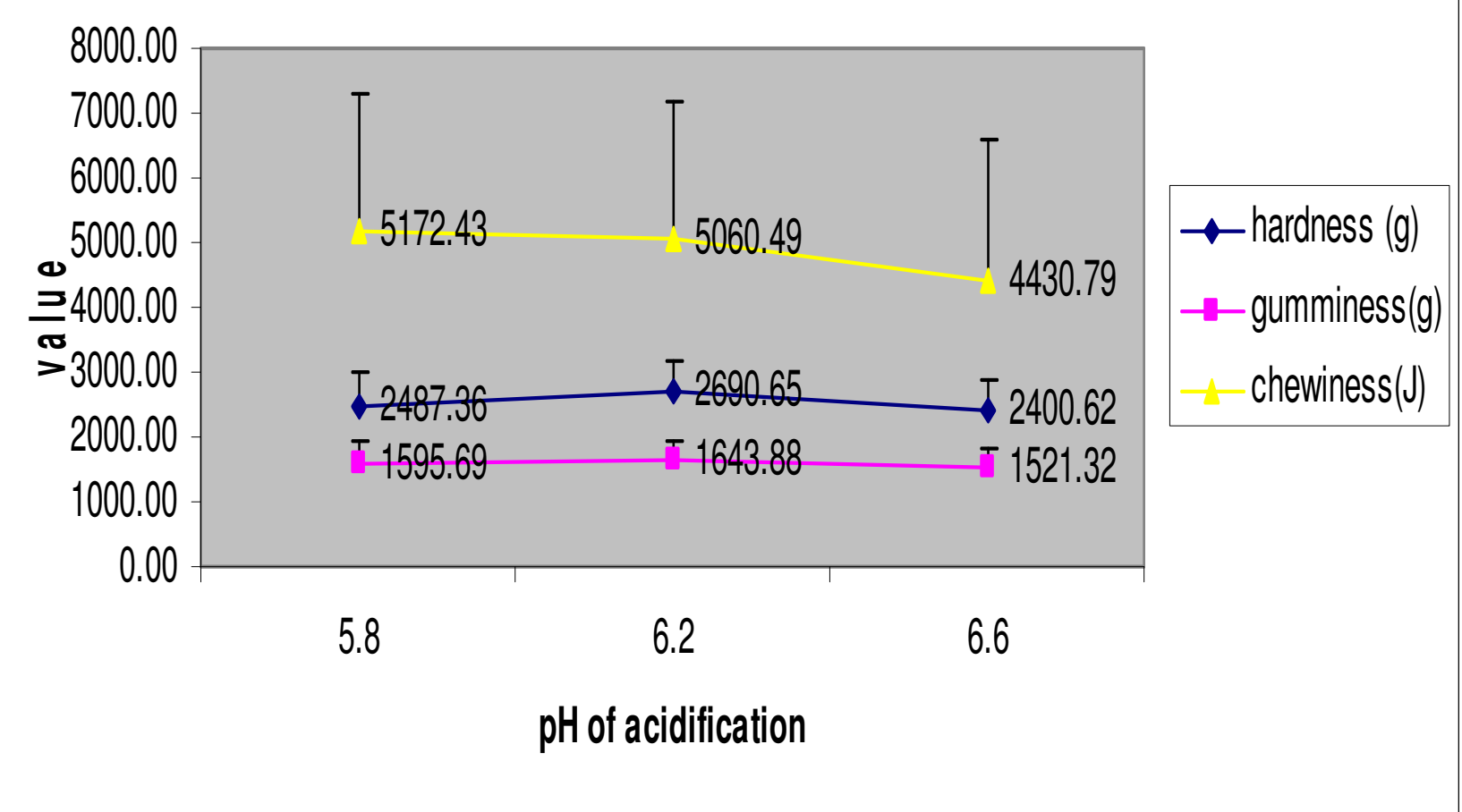

Figure 5.16 Effect of acidification on hardness, gumminess and chewiness of HPDF (for +1 Standard Error, $n=3$ ) 


\section{Effect of pH of acidification on texture}

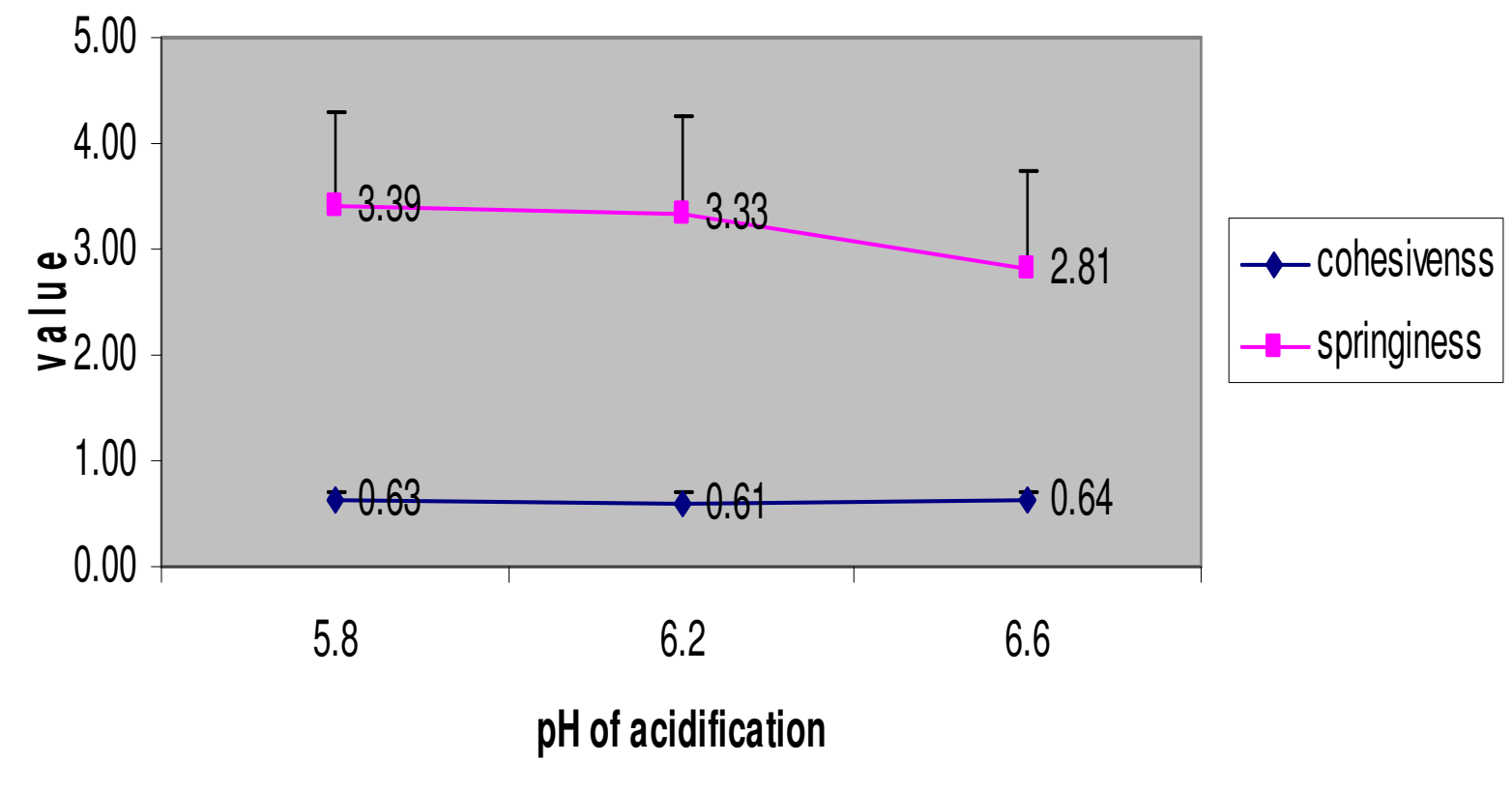

Figure 5.17 Effect of acidification on cohesiveness and springiness of HPDF (for +1 Standard Error, $n=3$ ) 


\section{Effect of homogenization on texture}

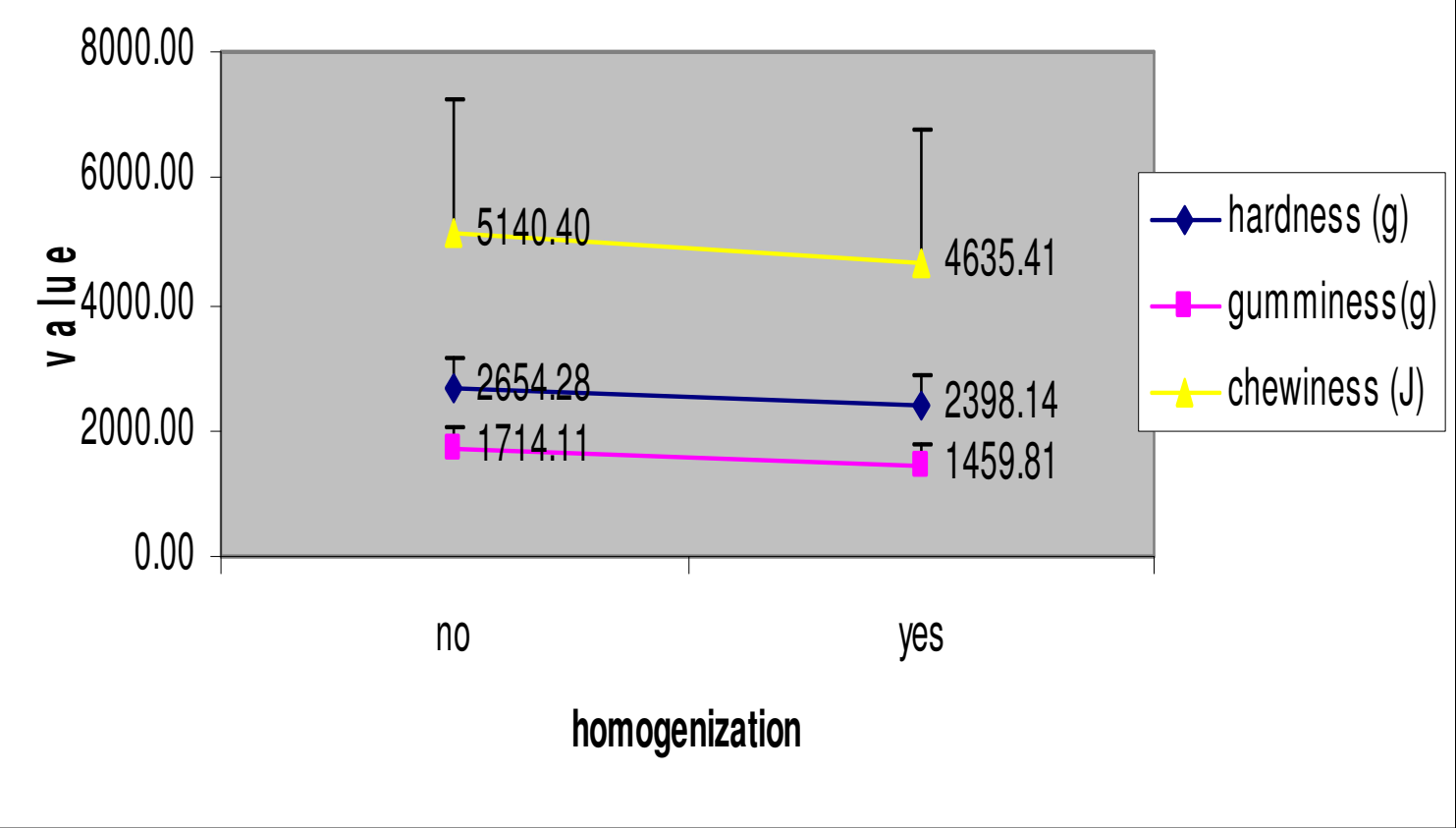

Figure 5.18 Effect of homogenization on hardness, gumminess and chewiness of HPDF (for +1 Standard Error, n=3) 


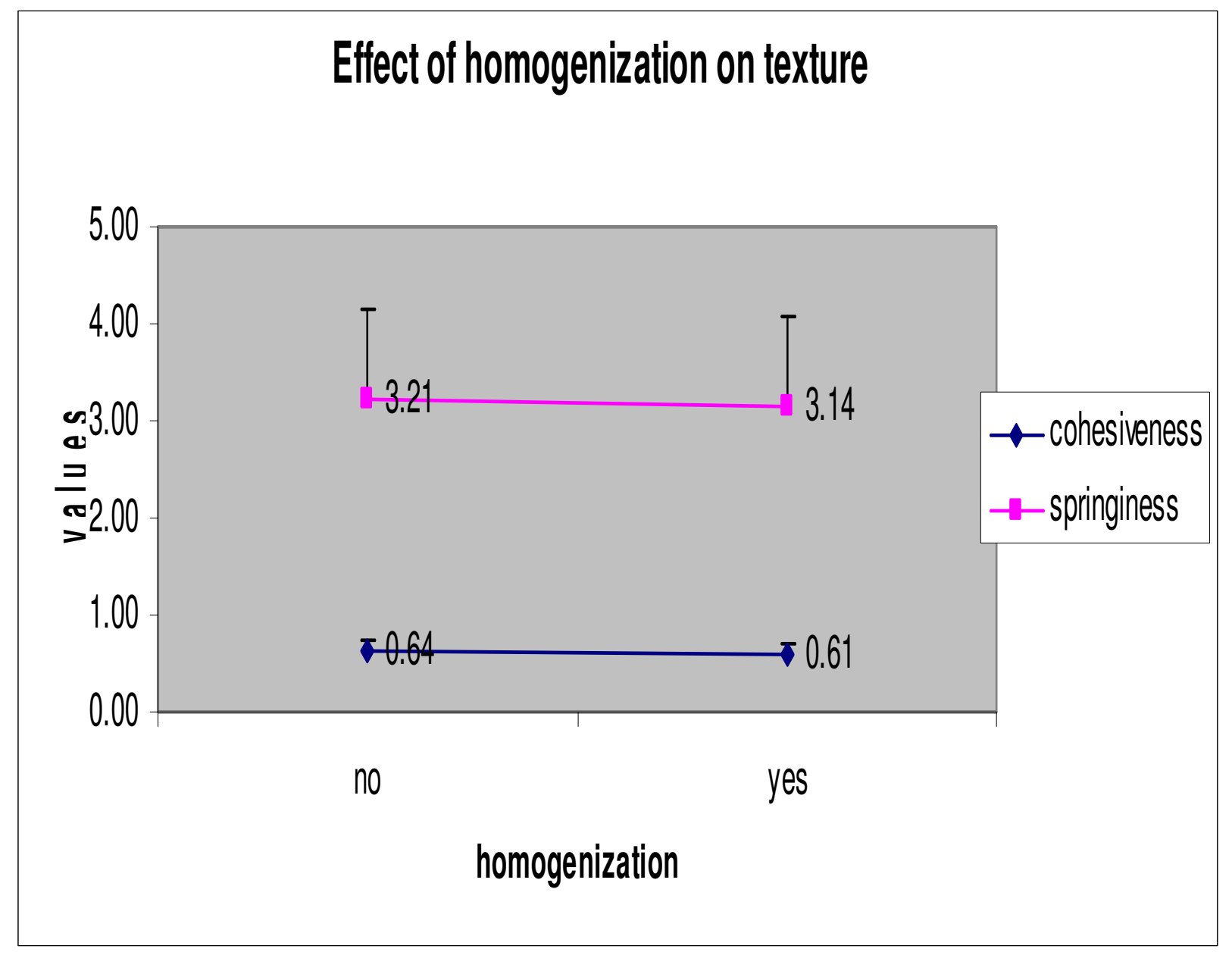

Figure 5.19 Effect of homogenization on cohesiveness and gumminess of HPDF (for +1 Standard Error, $n=3$ ) 
Table 5.11 p-values of test of significance of mean hardness, cohesiveness and springiness, gumminess and chewiness at different acidification, pasteurization and homogenization levels.

\begin{tabular}{|c|c|c|c|c|c|}
\hline Factors & Hardness & Cohesiveness & Springiness & Gumminess & Chewiness \\
\hline Acidification & 0.544 & 0.765 & 0.455 & 0.753 & 0.769 \\
\hline Pasteurization & $\mathbf{0 . 0 1 4}$ & 0.89 & 0.146 & $\mathbf{0 . 0 1 9}$ & 0.222 \\
\hline Homogenization & 0.277 & 0.311 & 0.862 & 0.12 & 0.594 \\
\hline acidpast & $\mathbf{0 . 0 3 2}$ & 0.72 & 0.624 & $\mathbf{0 . 0 2 4}$ & 0.231 \\
\hline acid*homo & 0.059 & 0.595 & 0.23 & $\mathbf{0 . 0 3 9}$ & 0.838 \\
\hline past*homo & 0.755 & 0.282 & 0.728 & 0.249 & 0.715 \\
\hline
\end{tabular}

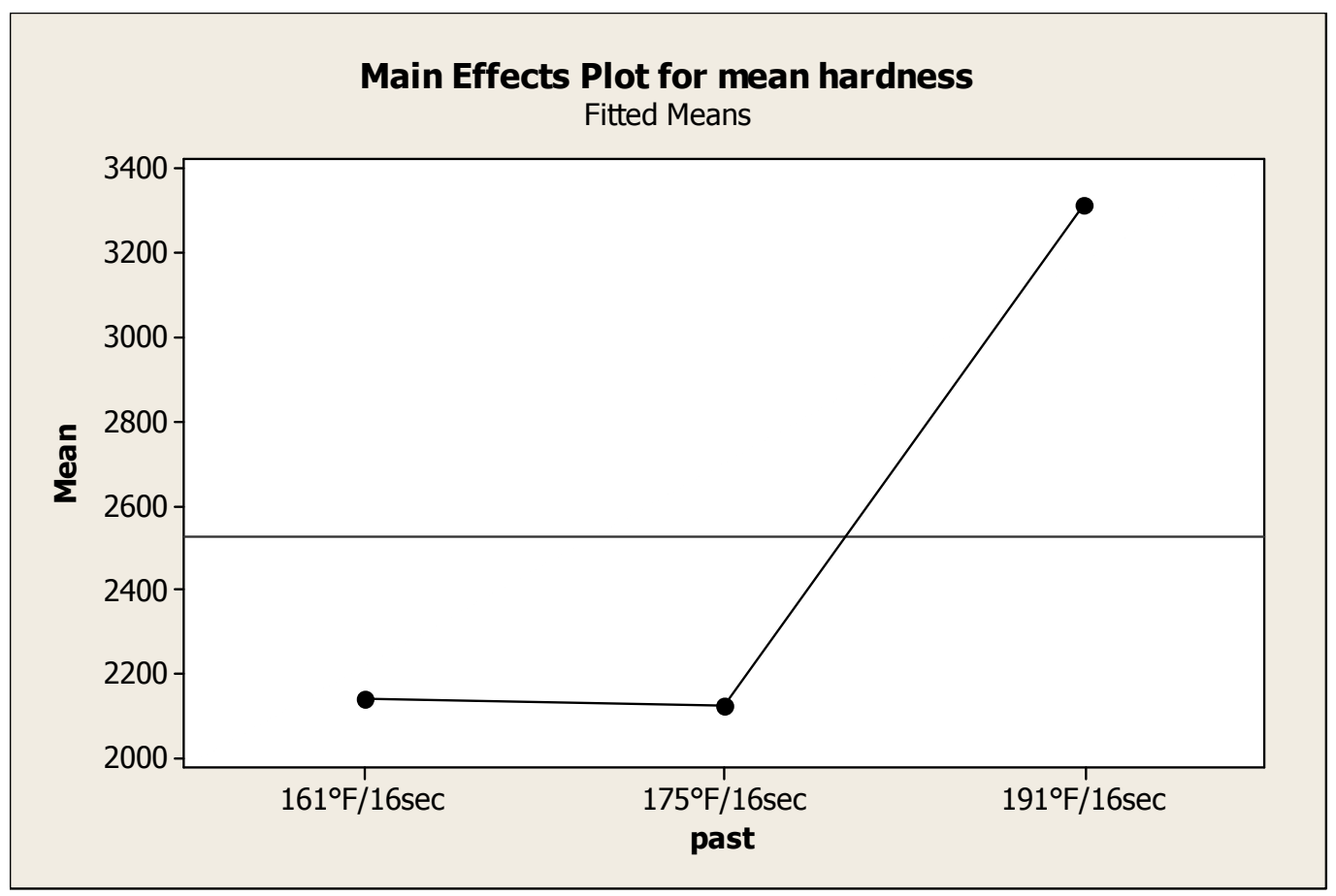

Figure 5.20 Main Effects plot for mean hardness vs. pasteurization 


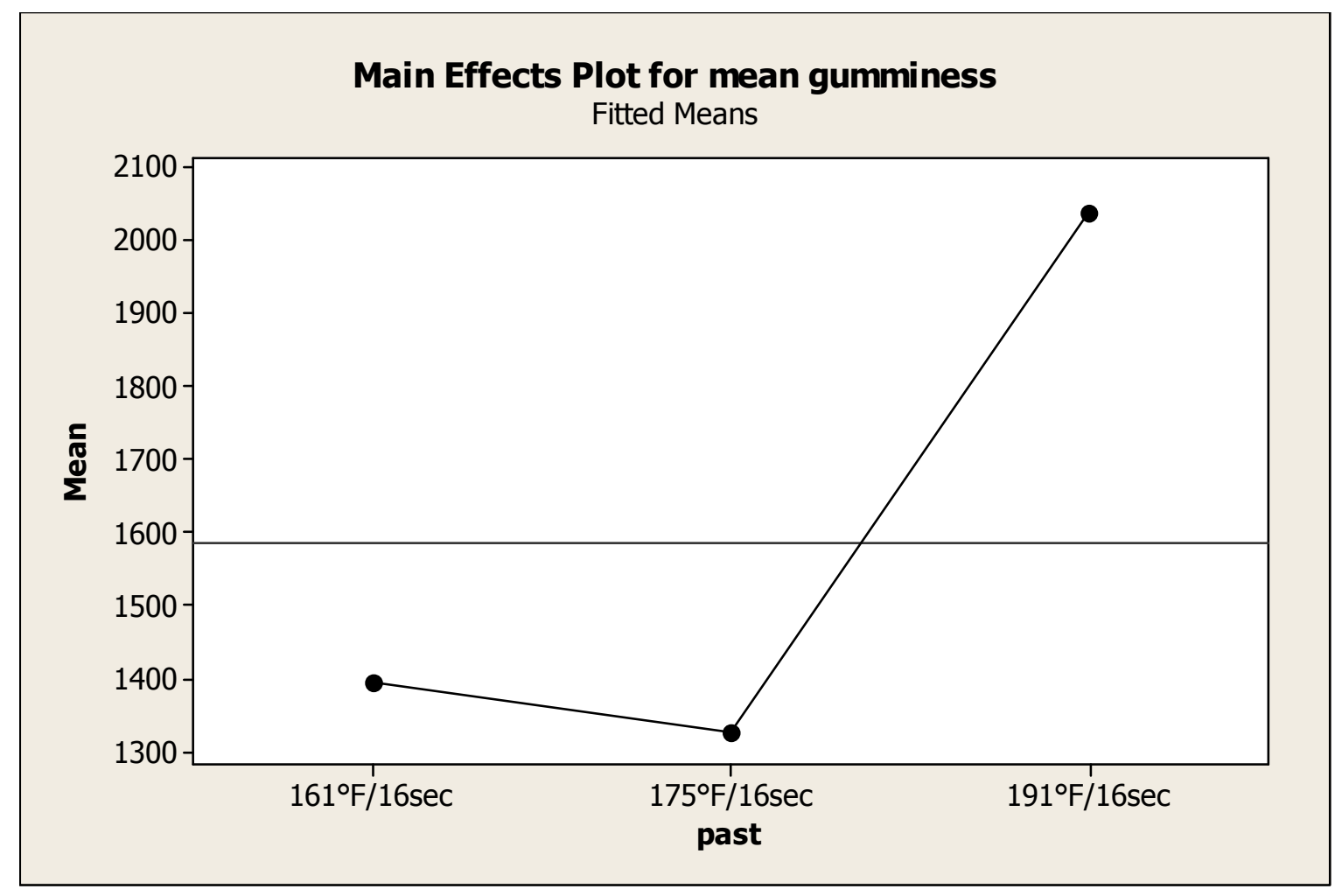

Figure 5.21 Main Effects plot for mean gumminess vs. pasteurization

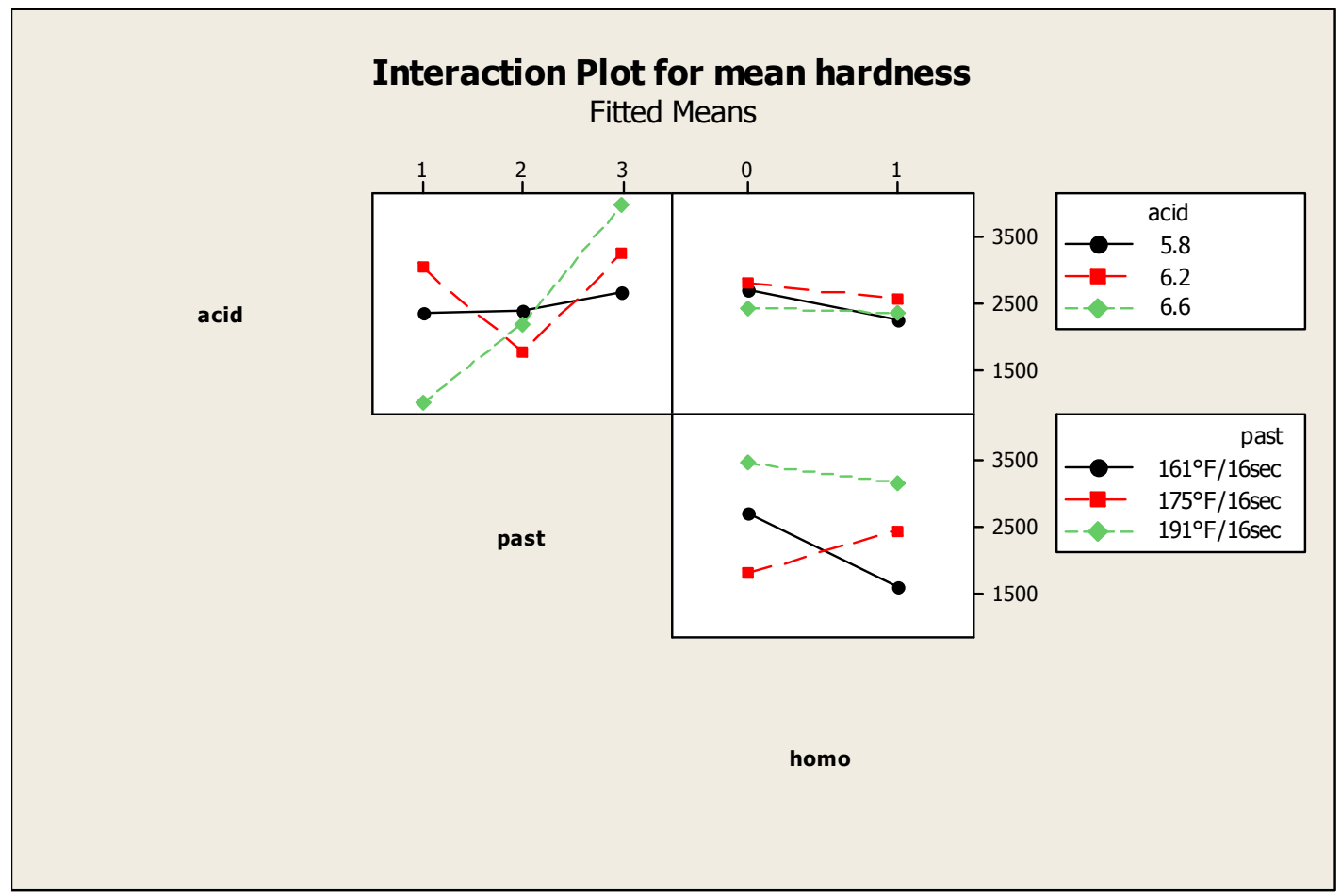

Figure 5.22 Interaction Plot for mean hardness vs. pasteurization, $\mathrm{pH}$ of acidification and homogenization 


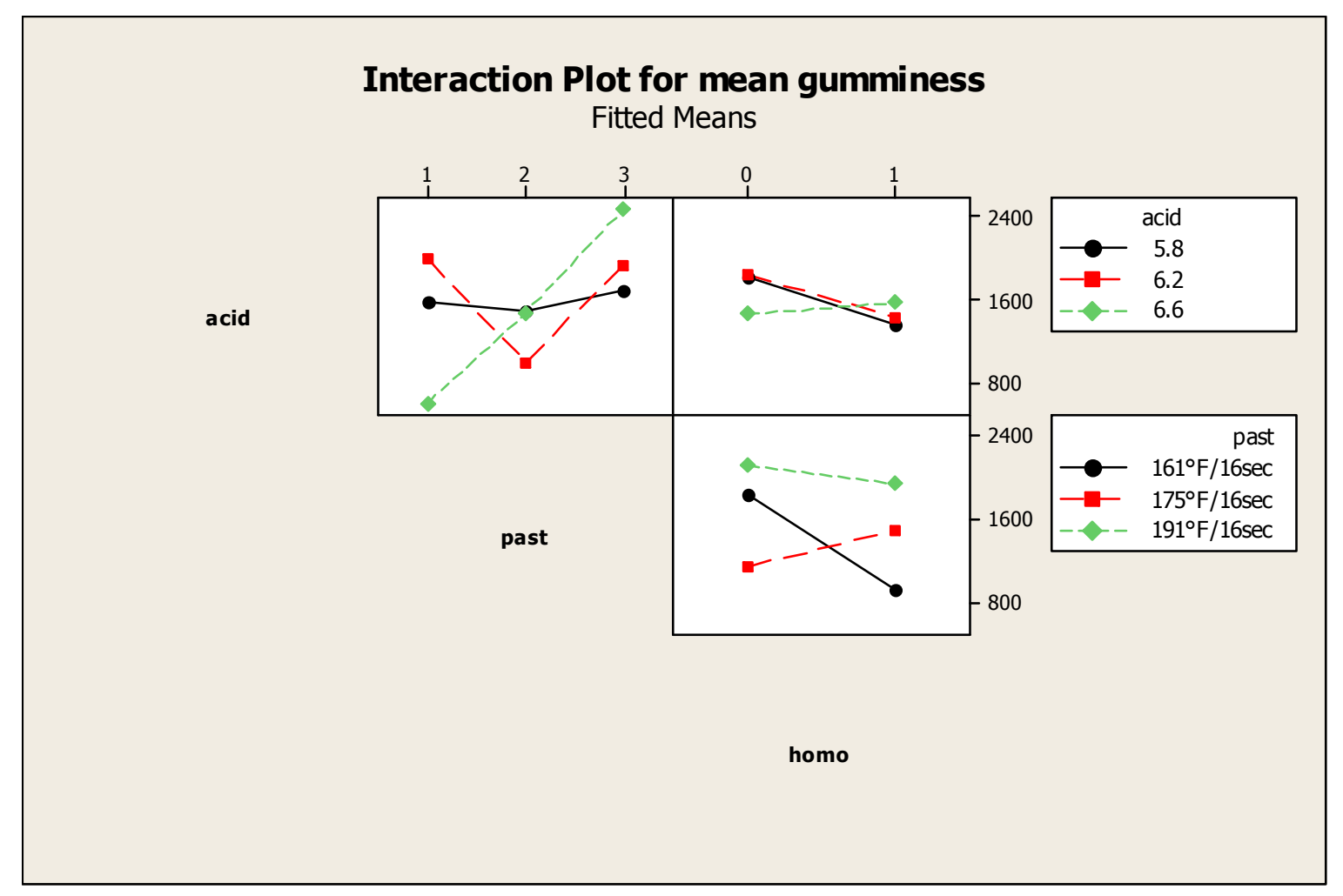

Figure 5.23 Interaction Plot for mean gumminess vs. pasteurization, $\mathrm{pH}$ of acidification and homogenization

\subsubsection{Significance of Experiment Design I}

Since the purpose of first set of experiment was to screen the levels of processing treatments, there were no duplicate batches of HPDF for each treatment levels. Therefore, the power of this experiment was low, but the experiment was successful in giving directions to design future set of experiments. There was significant difference between flowability of HPDF manufactured from milk pasteurized at $191^{\circ} \mathrm{F} / 16$ seconds and that from milk pasteurized at $161^{\circ} \mathrm{F} / 16$ seconds. Hence, the treatment levels were explored in the second stage of experiments. Compositional properties of HPDF, mainly mean protein and mean moisture content were significantly affected by three levels (5.8, 6.2 and 6.6) of $\mathrm{pH}$ of acidification and homogenization. The three levels of $\mathrm{pH}$ of acidification were investigated in the second experimental design, whereas homogenization (two stage2500psi/50 psi) were investigated in the third experimental design. 


\subsection{Heat treatment and acidification effect}

Based on the findings of the broad first stage experiment (section 5.2), a more focused second stage of experiment was designed to explore the effect of heat treatment and acidification. In the first stage, flow properties were significantly affected by heating conditions, whereas composition of HPDF was significantly affected by all the three factors (heating conditions, $\mathrm{pH}$ of acidification and homogenization). The second stage experiment consists of two levels of heating conditions and three levels of acidification. The effect of homogenization was studied in the following stage (section 5.4)

\subsubsection{Compositional analysis}

The HPDF was analyzed for fat, protein and moisture content and the results are as per Table 5.12, Table 5.13 and Table 5.14. The results are discussed in sections 5.3.1.1 and 5.3.1.2.

\subsubsection{Fat content}

Table 5.12 Effect of heating conditions and $\mathrm{pH}$ of acidification on mean fat content of HPDF (for sample size $\mathrm{n}=2$ )

\begin{tabular}{|c|c|c|c|c|}
\hline batch & $\begin{array}{c}\mathrm{pH} \text { of } \\
\text { acidification }\end{array}$ & $\begin{array}{c}\text { pasteurization } \\
\text { condition }\end{array}$ & $\begin{array}{c}\text { Mean } \\
\text { fat }\end{array}$ & $\begin{array}{c}\text { Standard } \\
\text { error }\end{array}$ \\
\hline 1 & 5.8 & $161^{\circ} \mathrm{F} / 16 \mathrm{sec}$ & 10.50 & 0.29 \\
\hline 2 & 6.2 & $161^{\circ} \mathrm{F} / 16 \mathrm{sec}$ & 10.00 & 0.25 \\
\hline 3 & 6.6 & $161^{\circ} \mathrm{F} / 16 \mathrm{sec}$ & 10.75 & 0.25 \\
\hline 4 & 5.8 & $191^{\circ} \mathrm{F} / 16 \mathrm{sec}$ & 11.00 & 0.25 \\
\hline 5 & 6.2 & $191^{\circ} \mathrm{F} / 16 \mathrm{sec}$ & 10.75 & 0.25 \\
\hline 6 & 6.6 & $191^{\circ} \mathrm{F} / 16 \mathrm{sec}$ & 10.75 & 0.00 \\
\hline
\end{tabular}

The fat content of HPDF was within the range of 10-11\% (Table 5.12), which confirmed the results of the fat content of HPDF during first stage. Again, the fat content was lower because of lower initial fat content (1\%) of standardized milk. None of the factors were significant 
independently or in interaction (Table 5.14). Thus fat content of HPDF is independent of pasteurization condition and $\mathrm{pH}$ of acidification. The result is consistent with that of the first stage of experiment. 


\subsubsection{Protein and moisture content}

From Table 5.13 and Figure 5.24, it can be seen that the mean protein content of HPDF varies in the range of $28-34 \%$, which is consistent with the results of first stage of experiment. The mean protein content of HPDF from milk pasteurized at $191^{\circ} \mathrm{F}$ for $16 \mathrm{sec}$ is slightly higher than that pasteurized at $161^{\circ} \mathrm{F}$ for $16 \mathrm{sec}$. This can be due to heat induced denaturation of serum protein and its subsequent association with casein micelles, as explained earlier in the first stage results. $\mathrm{pH}$ plays an important role in determining mean protein content of HPDF by controlling the quantity of the denatured whey protein introduced in the casein matrix. The interaction between $\mathrm{pH}$ and pasteurization condition is significant for mean protein content.

Table 5.13 Effect of heating conditions and $\mathrm{pH}$ of acidification on mean protein content of HPDF (for sample size $n=2$ )

\begin{tabular}{|c|c|c|c|c|}
\hline batch & $\begin{array}{c}\mathrm{pH} \text { of } \\
\text { acidification }\end{array}$ & $\begin{array}{c}\text { Pasteurization } \\
\text { condition }\end{array}$ & $\begin{array}{c}\text { mean } \\
\text { protein }\end{array}$ & $\begin{array}{c}\text { Standard } \\
\text { error }\end{array}$ \\
\hline 1 & 5.8 & $161^{\circ} \mathrm{F} / 16 \mathrm{sec}$ & 28.53 & 0.37 \\
\hline 2 & 6.2 & $161^{\circ} \mathrm{F} / 16 \mathrm{sec}$ & 29.76 & 0.45 \\
\hline 3 & 6.6 & $161^{\circ} \mathrm{F} / 16 \mathrm{sec}$ & 28.58 & 0.67 \\
\hline 4 & 5.8 & $191^{\circ} \mathrm{F} / 16 \mathrm{sec}$ & 28.36 & 0.28 \\
\hline 5 & 6.2 & $191^{\circ} \mathrm{F} / 16 \mathrm{sec}$ & 32.17 & 0.99 \\
\hline 6 & 6.6 & $191^{\circ} \mathrm{F} / 16 \mathrm{sec}$ & 32.13 & 0.58 \\
\hline
\end{tabular}




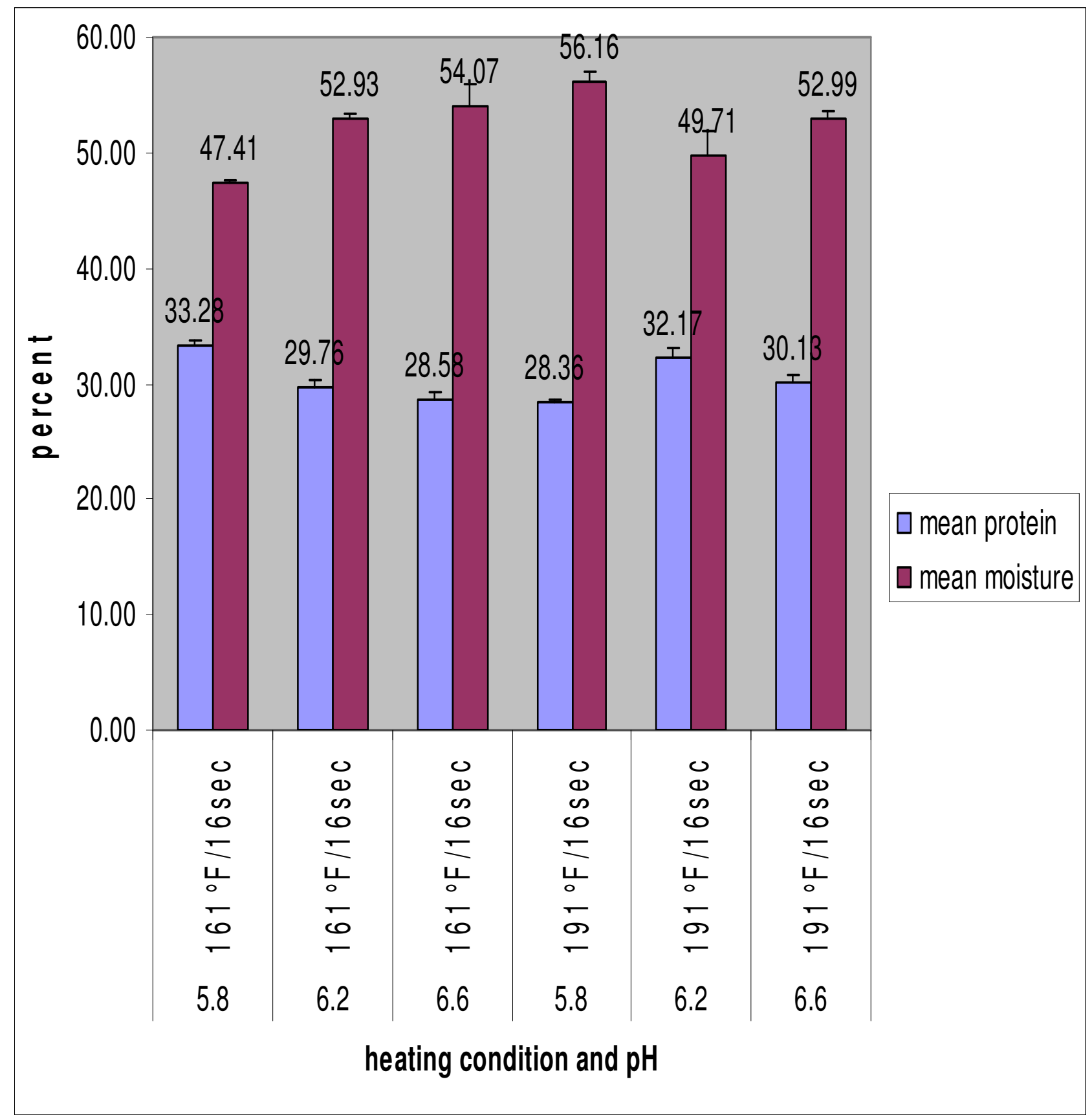

Figure 5.24 Effect of heating condition and $\mathrm{pH}$ of acidification on mean protein and mean moisture content of HPDF. (for +1 Standard Error, $n=2$ ) 
Table 5.14 Effect of heating conditions and $\mathrm{pH}$ of acidification on mean moisture content of HPDF (for sample size $n=2$ )

\begin{tabular}{|c|c|c|c|c|}
\hline Batch & $\begin{array}{c}\mathrm{pH} \text { of } \\
\text { acidification }\end{array}$ & $\begin{array}{c}\text { pasteurization } \\
\text { condition }\end{array}$ & mean & standard \\
\hline 1 & 5.8 & $161^{\circ} \mathrm{F} / 16 \mathrm{sec}$ & 47.41 & 0.15 \\
\hline 2 & 6.2 & $161^{\circ} \mathrm{F} / 16 \mathrm{sec}$ & 52.93 & 0.37 \\
\hline 3 & 6.6 & $161^{\circ} \mathrm{F} / 16 \mathrm{sec}$ & 54.07 & 1.94 \\
\hline 4 & 5.8 & $191^{\circ} \mathrm{F} / 16 \mathrm{sec}$ & 56.16 & 0.81 \\
\hline 5 & 6.2 & $191^{\circ} \mathrm{F} / 16 \mathrm{sec}$ & 49.71 & 2.28 \\
\hline 6 & 6.6 & $191^{\circ} \mathrm{F} / 16 \mathrm{sec}$ & 52.99 & 0.50 \\
\hline
\end{tabular}

From Table 5.14 and Figure 5.24, moisture content of HPDF ranged from 47-56\%, which is consistent with the result of first stage of experimentation. The moisture content of HPDF made from milk pasteurized at $191^{\circ} \mathrm{F} / 16 \mathrm{sec}$ is higher, because of higher water holding capacity of caseinwhey protein (particularly $\kappa$-casein/ $\beta$-lactoglobulin) complex formed.

From Table 5.15, none of the factors are significant for fat content of HPDF. For protein and moisture content, there is an interaction between the two factors suggesting that effect of $\mathrm{pH}$ of acidification on moisture and protein content is dependent on pasteurization condition. The tukey 95\% confidence interval for protein content suggests that protein content in HPDF at manufactured at $\mathrm{pH} 6.2$ is significantly higher than that manufactured at pH 6.6 (Appendix 2.1). 
Table 5.15 p-values of test of significance of mean protein, fat and moisture at different acidification and pasteurization conditions.

\begin{tabular}{|c|c|c|c|}
\hline Factors & mean protein & mean moisture & mean fat \\
\hline Acidification & $\mathbf{0 . 0 2 9}$ & 0.224 & 0.161 \\
\hline & & & \\
pasteurization & 0.527 & 0.176 & 0.404 \\
\hline & & & \\
acid*past & $\mathbf{0 . 0 0 0}$ & $\mathbf{0 . 0 0 0}$ & 0.141 \\
\hline
\end{tabular}

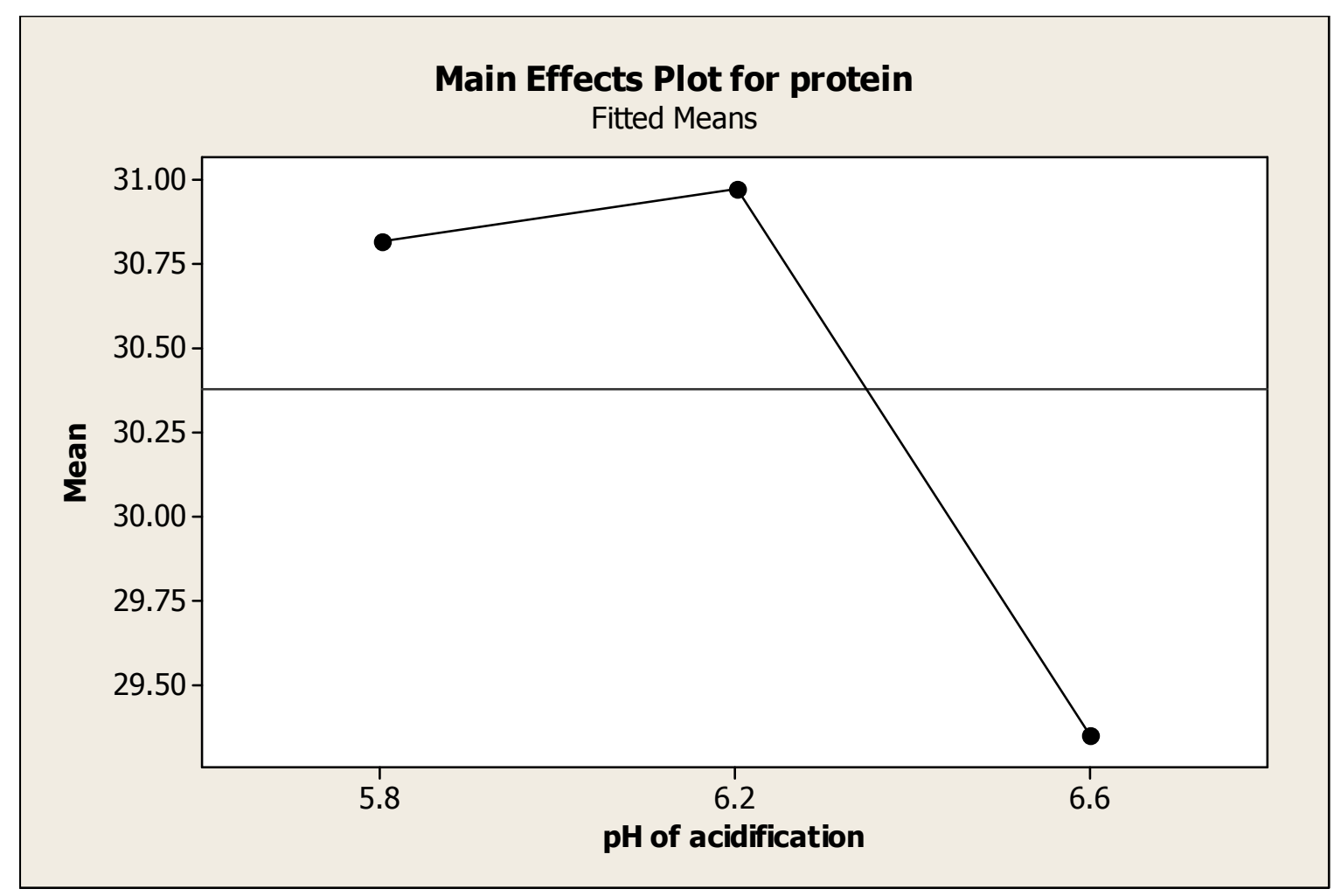

Figure 5.25 Main Effects Plot for mean protein vs. pH of acidification 


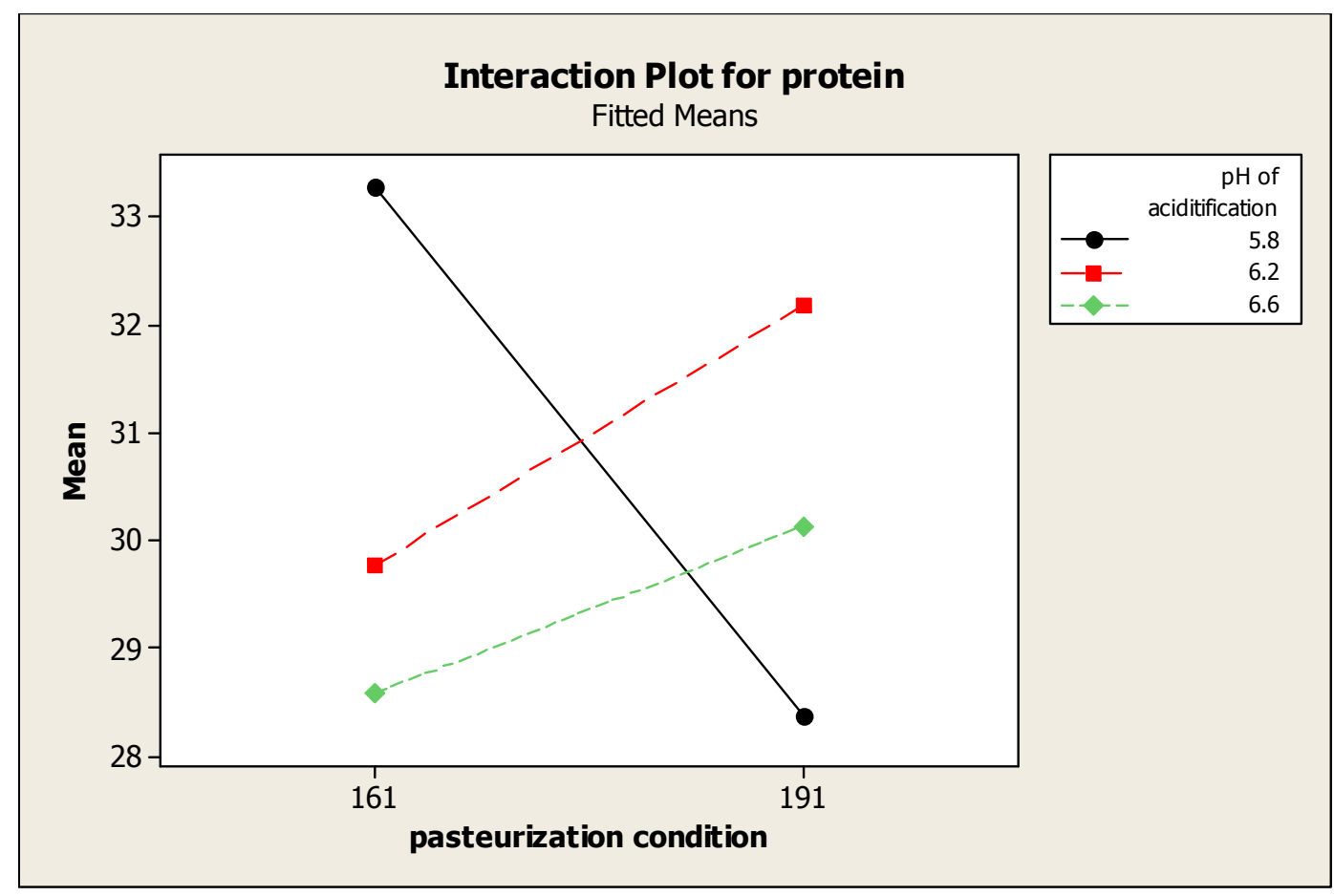

Figure 5.26 Interaction Plot of mean protein vs. $\mathrm{pH}$ of acidification and pasteurization condition

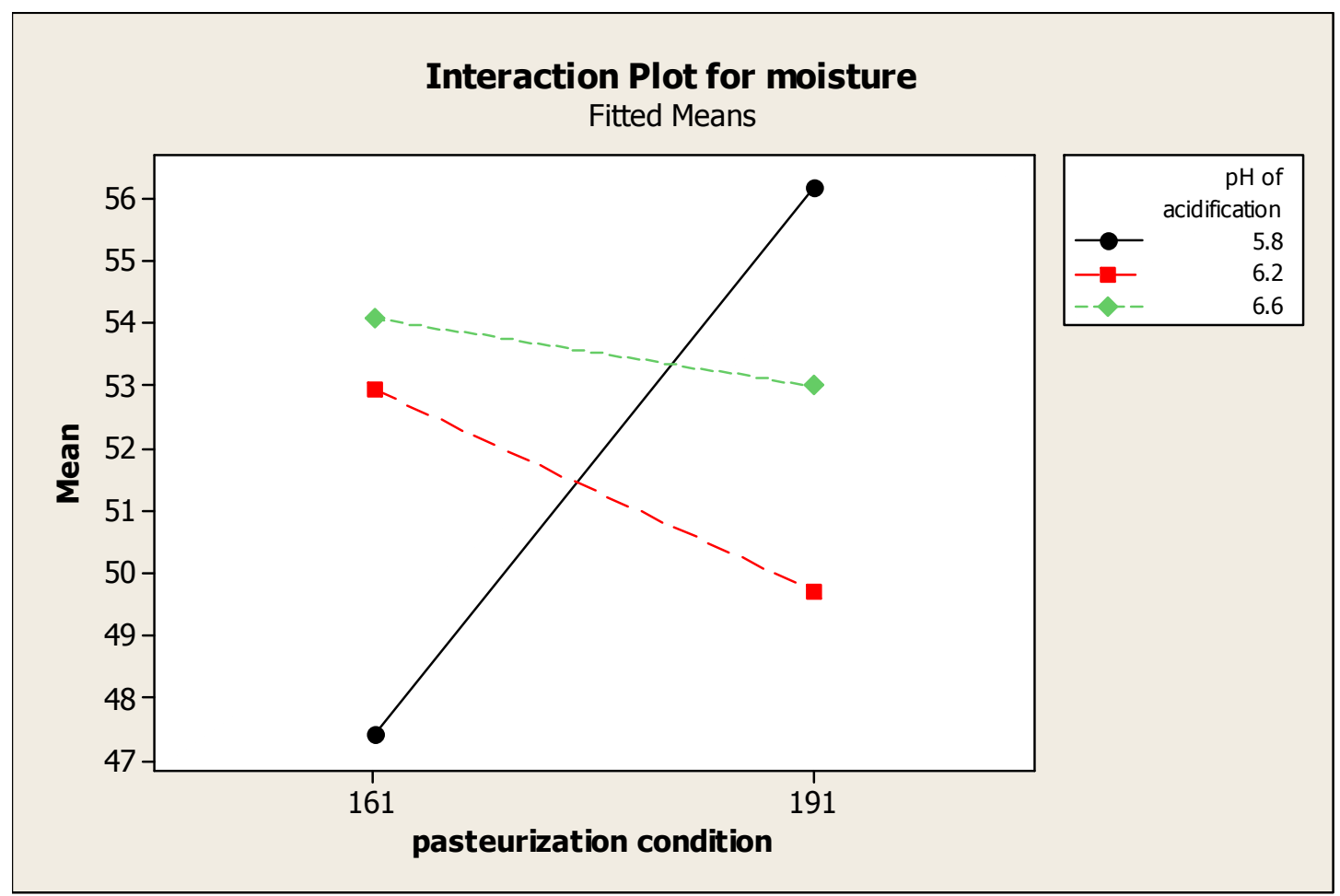

Figure 5.27 Interaction Plot of mean moisture vs $\mathrm{pH}$ of acidification and pasteurization condition 


\subsubsection{Analysis of flow properties}

The HPDF was analyzed for flow properties and the 'flow unit' under oven, microwave and hot water is presented in Tables 5.16, 5.17 and 5.18 respectively. Figures 5.31 and 5.32 are the corresponding graphs.

From Figure 5.31 again confirms effect of high pasteurization treatment on flow resistance of HPDF. As the temperature of pasteurization increases, the flowability of HPDF decreases. Horne et al. (1994) suggested that thermal gelation of denatured whey proteins and/or complexes of denatured whey proteins and para- $\kappa$-casein reduces the flow of the heated cheese. It is noteworthy that high levels of protein and soluble calcium in cheese (Harvey et al., 1982) probably enhance the heat-induced interaction and gelation of para- $\kappa$-casein/ $\beta$-lactoglobulin (Doi et al., 1983, Jelen and Rattray, 1995). The flow properties of Mozzarella cheese, as measured from the percentage decrease in the height of a cheese disc on heating, decreased by $\sim 40 \%$ as the level of whey protein denaturation in cheese milk was increased from $\sim 5$ to $35 \%$ (Schafer and Olson, 1975). The positive relationship between flow resistance and high heat treatment in this experiment is supported statistically by p-value for pasteurization condition on flowing (Table 5.19).

From Figures 5.28, 5.29 and 5.30, effect of $\mathrm{pH}$ of acidification seems to depend upon pasteurization condition. For lower pasteurization condition, pH 5.8 had negative impact on flow resistance, whereas for higher pasteurization condition, the $\mathrm{pH}$ had positive impact. Flowability is displacement of contiguous lanes of para-casein matrix as a result of heat induced stress (Fox, 1981). Once fat coalescence is initiated, the para-casein matrix flows to a degree determined by the concentration of casein and the level of casein hydration, which is controlled by $\mathrm{pH}$, total calcium and ratio of soluble-to-miceller calcium (Olson et al., 1998). Yun et al. (1995) reported that initiating whey drainage at pH 6.4 compared with 6.15 resulted in significantly higher Ca levels in 
Mozzarella cheese. During acidification, the loss of Ca from the casein particles results in a weaker association between casein molecules, which increases the flow and flow of the cheese when heated. The $\tan \delta$ of acid induced gels made from heated milk and milk gels made by a combination of rennet and acidification (Roefs et al., 1990) exhibits a maximum at $\mathrm{pH} 5.2$, probably due to the loss of miceller calcium from the casein matrix while $\tan \delta$ decreases at low $\mathrm{pH}$ values. Therefore, $\mathrm{pH}$ in combination with level of calcium impacts the flowability of the HPDF. The effect of $\mathrm{pH}$ on flowing properties of HPDF can be statistically supported by p-value (Table 5.19).

However, formation of para- $\kappa$-casein/ $\beta$-lactoglobulin during high heat treatment acts to restrict the mobility of the protein upon being subjected to heating and, hence, acts to restrict the flowing of the cheese (Strandholm et al., 1989). The low flowing property of HPDF at high temperature and low $\mathrm{pH}$ may be attributed to this fact. The corresponding $\mathrm{p}$-value indicates flowing quality depends upon interaction between $\mathrm{pH}$ and heat treatment.

The interaction is an important result of second stage of experiment. During the first stage, the interaction between $\mathrm{pH}$ and heat treatment was not significant (Table 5.11) but the two factors were tested on the second stage with duplicate. As a result, power of experimental design increased and the interaction was significant. 
Table 5.16 Effect of heating conditions and $\mathrm{pH}$ of acidification on mean flow in oven of HPDF (for sample size $\mathrm{n}=4,1$ flow unit $=10 \mathrm{~mm}$ flow, flow unit $<1$ is considered as flow resistance)

\begin{tabular}{|c|c|c|c|c|}
\hline Batch & $\begin{array}{c}\mathrm{pH} \text { of } \\
\text { acidification }\end{array}$ & $\begin{array}{c}\text { Pasteurization } \\
\text { Condition }\end{array}$ & $\begin{array}{c}\text { Mean flow } \\
\text { unit oven }\end{array}$ & Standard error \\
\hline 1 & 5.8 & $161^{\circ} \mathrm{F} / 16 \mathrm{sec}$ & 8.00 & 0.63 \\
\hline 2 & 6.2 & $161^{\circ} \mathrm{F} / 16 \mathrm{sec}$ & 2.33 & 0.52 \\
\hline 3 & 6.6 & $161^{\circ} \mathrm{F} / 16 \mathrm{sec}$ & 7.00 & 0.89 \\
\hline 4 & 5.8 & $191^{\circ} \mathrm{F} / 16 \mathrm{sec}$ & 0.17 & 0.41 \\
\hline 5 & 6.2 & $191^{\circ} \mathrm{F} / 16 \mathrm{sec}$ & 0.33 & 0.52 \\
\hline 6 & 6.6 & $191^{\circ} \mathrm{F} / 16 \mathrm{sec}$ & 1.50 & 0.55 \\
\hline
\end{tabular}


Table 5.17 Effect of heating conditions and $\mathrm{pH}$ of acidification on mean flow in microwave of HPDF (for sample size $n=4,1$ flow unit $=10 \mathrm{~mm}$ flow, flow unit $<1$ is considered as flow resistance)

\begin{tabular}{|c|c|c|c|c|}
\hline batch & $\begin{array}{c}\mathrm{pH} \text { of } \\
\text { acidification }\end{array}$ & $\begin{array}{c}\text { Pasteurization } \\
\text { condition }\end{array}$ & $\begin{array}{l}\text { Mean flow unit } \\
\text { microwave }\end{array}$ & $\begin{array}{l}\text { Standard } \\
\text { error }\end{array}$ \\
\hline 1 & 5.8 & $161^{\circ} \mathrm{F} / 16 \mathrm{sec}$ & 8.00 & 0.89 \\
\hline 2 & 6.2 & $161^{\circ} \mathrm{F} / 16 \mathrm{sec}$ & 4.33 & 0.52 \\
\hline 3 & 6.6 & $161^{\circ} \mathrm{F} / 16 \mathrm{sec}$ & 6.33 & 3.44 \\
\hline 4 & 5.8 & $191^{\circ} \mathrm{F} / 16 \mathrm{sec}$ & 0.33 & 0.82 \\
\hline 5 & 6.2 & $191^{\circ} \mathrm{F} / 16 \mathrm{sec}$ & 0.17 & 0.41 \\
\hline 6 & 6.6 & $191^{\circ} \mathrm{F} / 16 \mathrm{sec}$ & 3.33 & 1.75 \\
\hline
\end{tabular}


Table 5.18 Effect of heating conditions and $\mathrm{pH}$ of acidification on mean flow in hot water of HPDF (for sample size $n=4,1$ flow unit=10 mm flow, flow unit $<1$ is considered as flow resistance)

\begin{tabular}{|c|c|c|c|c|}
\hline batch & $\begin{array}{c}\mathrm{pH} \text { of } \\
\text { acidification }\end{array}$ & $\begin{array}{c}\text { Pasteurization } \\
\text { condition }\end{array}$ & $\begin{array}{l}\text { Mean flow unit } \\
\text { hot water }\end{array}$ & $\begin{array}{l}\text { Standard } \\
\text { error }\end{array}$ \\
\hline 1 & 5.8 & $161^{\circ} \mathrm{F} / 16 \mathrm{sec}$ & 6.00 & 0.63 \\
\hline 2 & 6.2 & $161^{\circ} \mathrm{F} / 16 \mathrm{sec}$ & 3.17 & 1.72 \\
\hline 3 & 6.6 & $161^{\circ} \mathrm{F} / 16 \mathrm{sec}$ & 5.50 & 1.05 \\
\hline 4 & 5.8 & $191^{\circ} \mathrm{F} / 16 \mathrm{sec}$ & 0.00 & 0.00 \\
\hline 5 & 6.2 & $191^{\circ} \mathrm{F} / 16 \mathrm{sec}$ & 0.00 & 0.00 \\
\hline 6 & 6.6 & $191^{\circ} \mathrm{F} / 16 \mathrm{sec}$ & 0.17 & 0.41 \\
\hline
\end{tabular}


Table 5.19 p-values of test of significance of mean flowing of HPDF in oven, microwave and hot water at different acidification and pasteurization conditions.

\begin{tabular}{|c|c|c|c|}
\hline Factors & flow in & flow in & Flow in hot \\
oven & microwave & water \\
\hline Pasteurization condition & $\mathbf{0}$ & $\mathbf{0 . 0 0 2}$ & $\mathbf{0 . 0 0 1}$ \\
\hline $\mathrm{pH}$ of acidification & $\mathbf{0}$ & $\mathbf{0}$ & $\mathbf{0}$ \\
\hline acidification*pasteurization & $\mathbf{0}$ & $\mathbf{0 . 0 0 5}$ & $\mathbf{0 . 0 0 1}$ \\
\hline
\end{tabular}

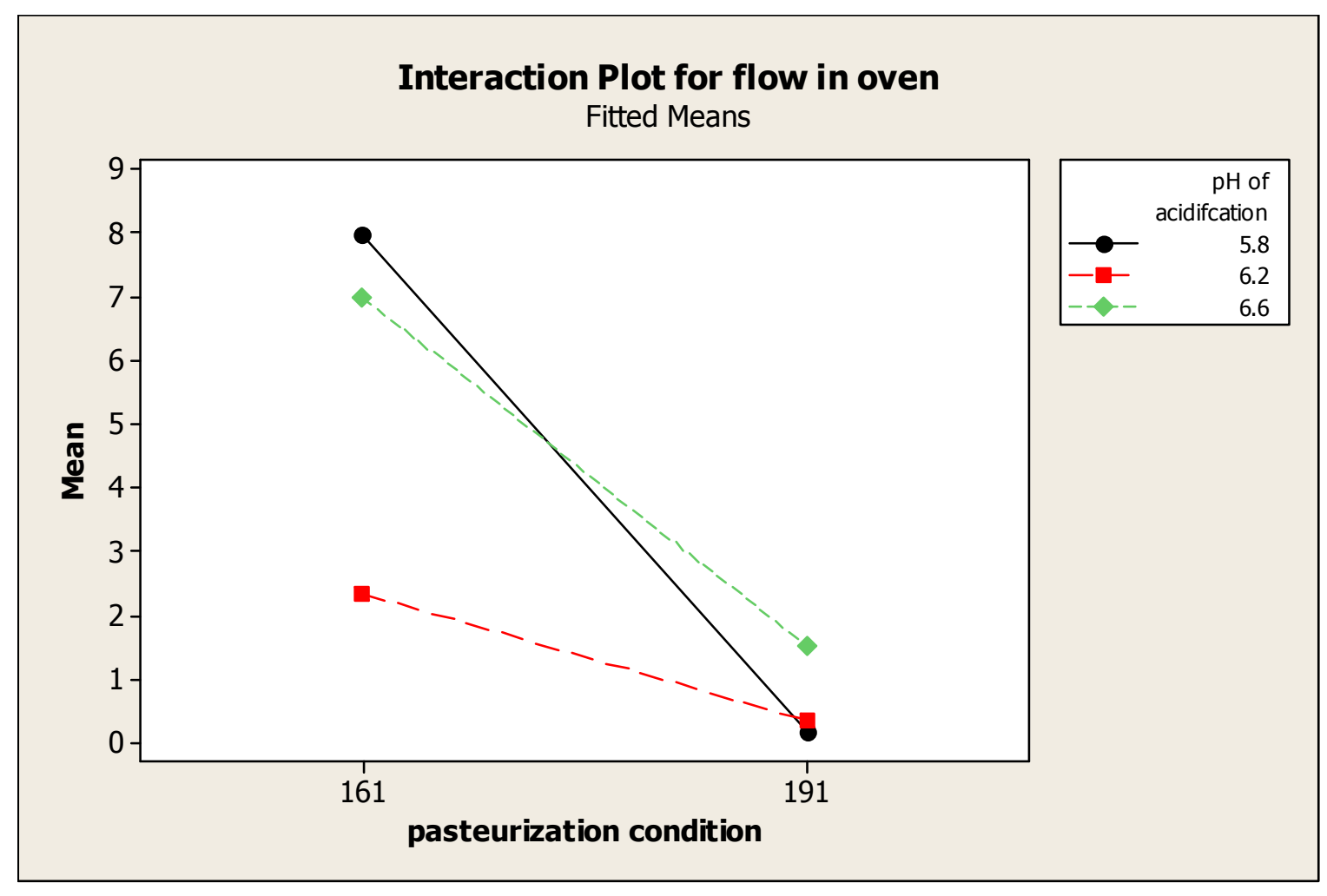

Figure 5.28 Interaction Plot for flow in oven vs. $\mathrm{pH}$ of acidification and pasteurization condition 


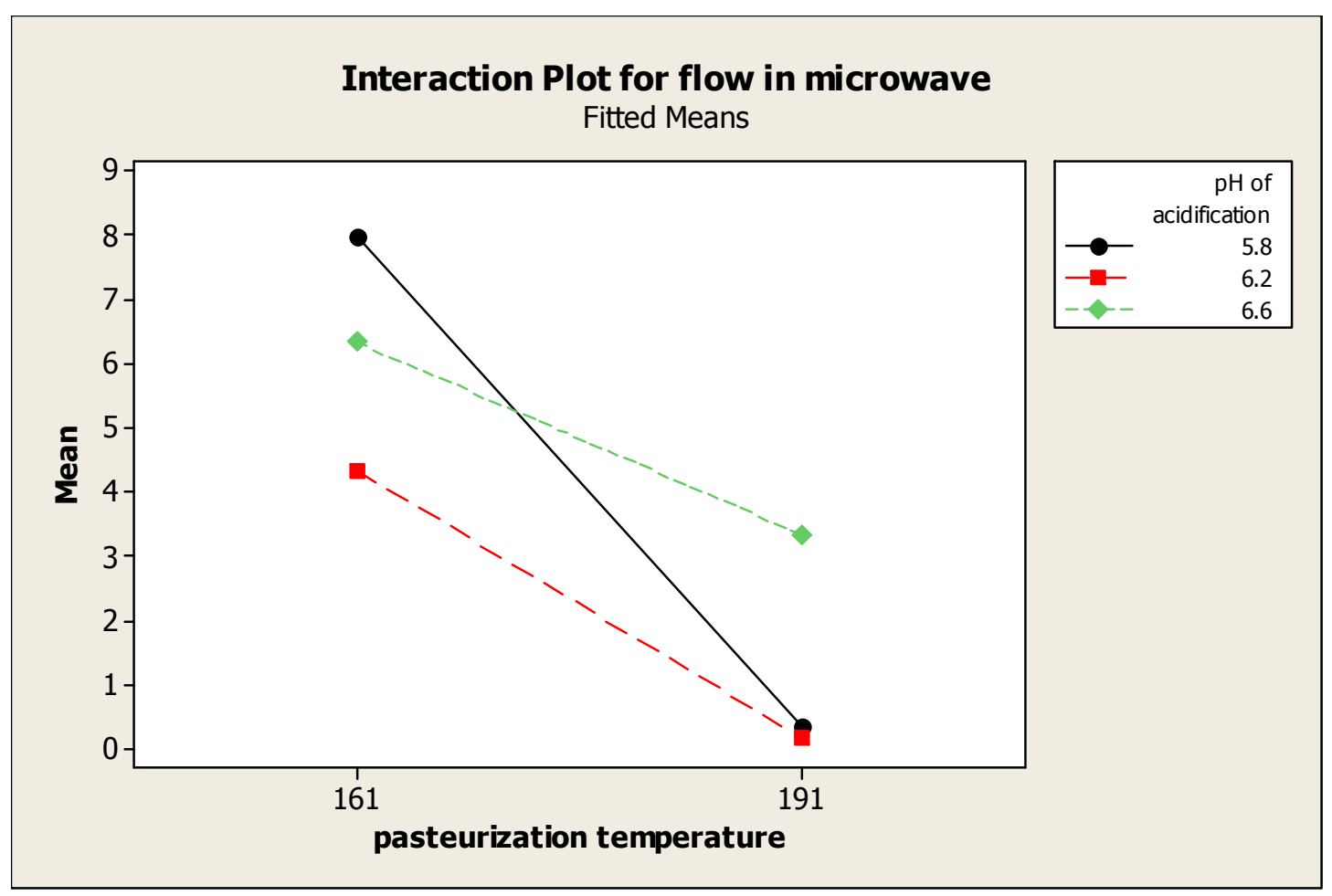

Figure 5.29 Interaction Plot for flow in microwave vs. $\mathrm{pH}$ of acidification and pasteurization temperature

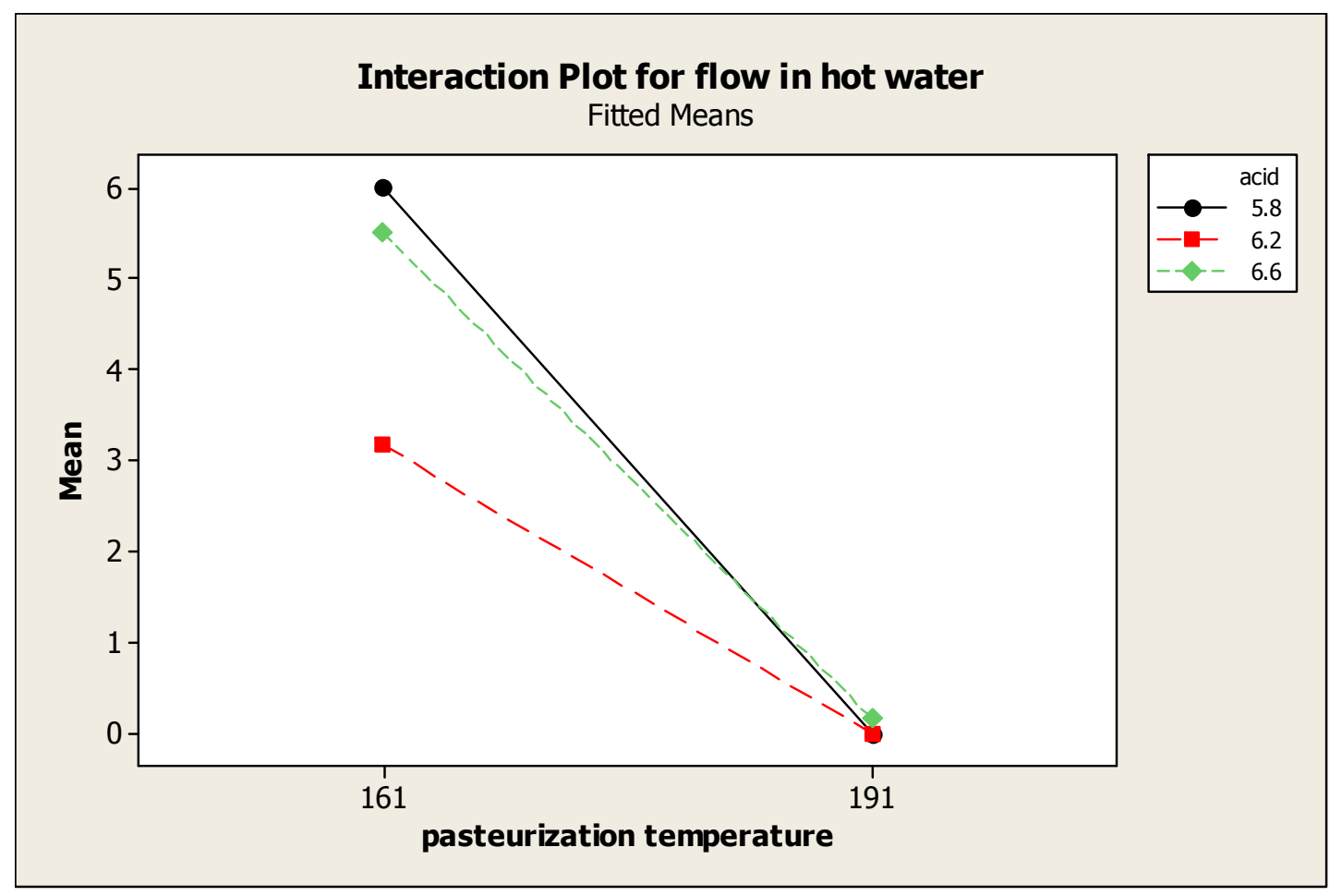

Figure 5.30 Interaction Plot for flow in microwave vs. $\mathrm{pH}$ of acidification and pasteurization temperature 


\section{EHtect of accidification at 191 F/16 sec}

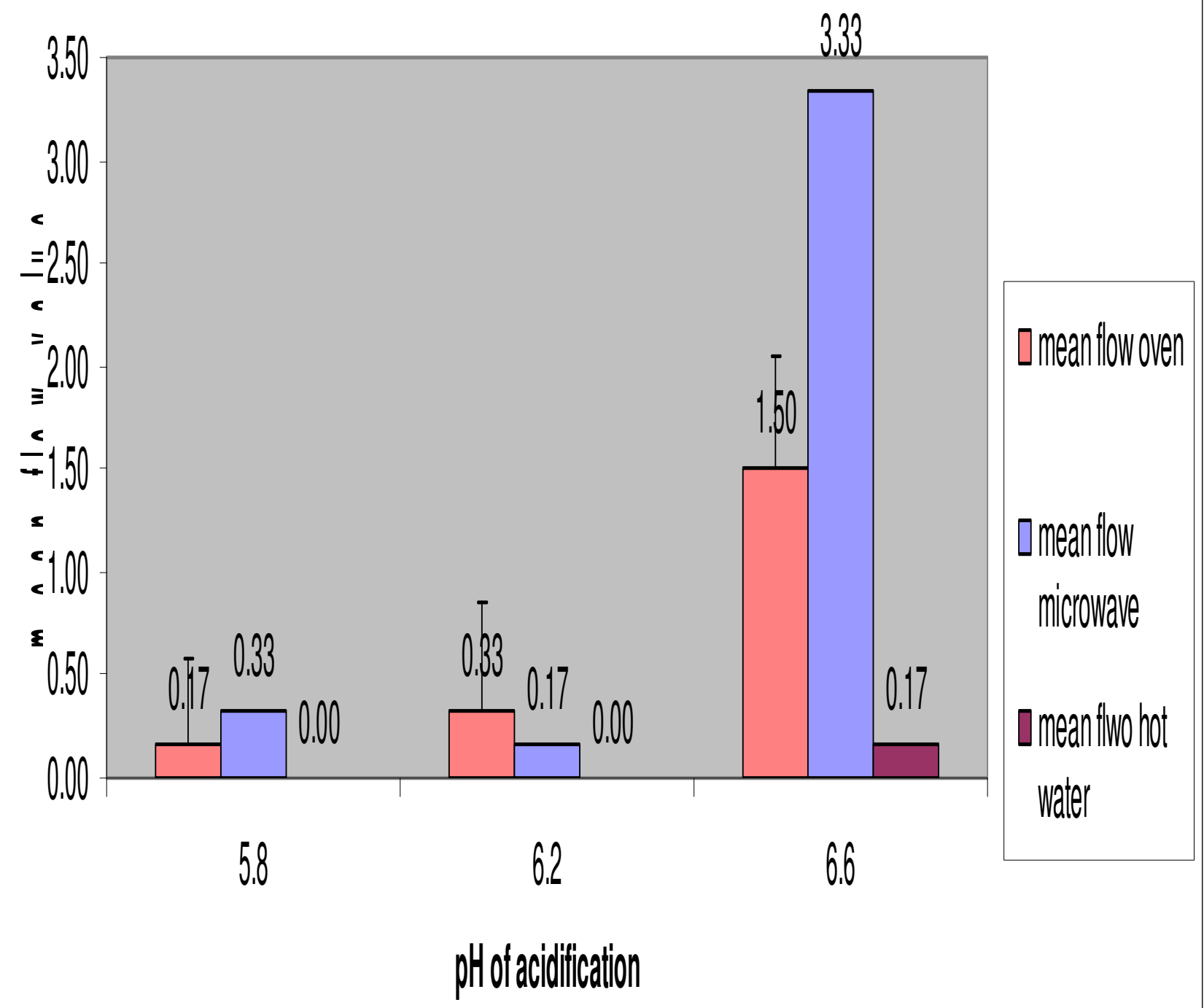

Figure 5.31 Effect of $\mathrm{pH}$ of acidification on mean flow value of HPDF manufactured from milk pasteurized at $191^{\circ} \mathrm{F} / 16 \mathrm{sec}$. (for +1 Standard Error, $\mathrm{n}=4$ ) 


\section{Effect of acidification at $161 \mathrm{~F} / 16 \mathrm{sec}$}

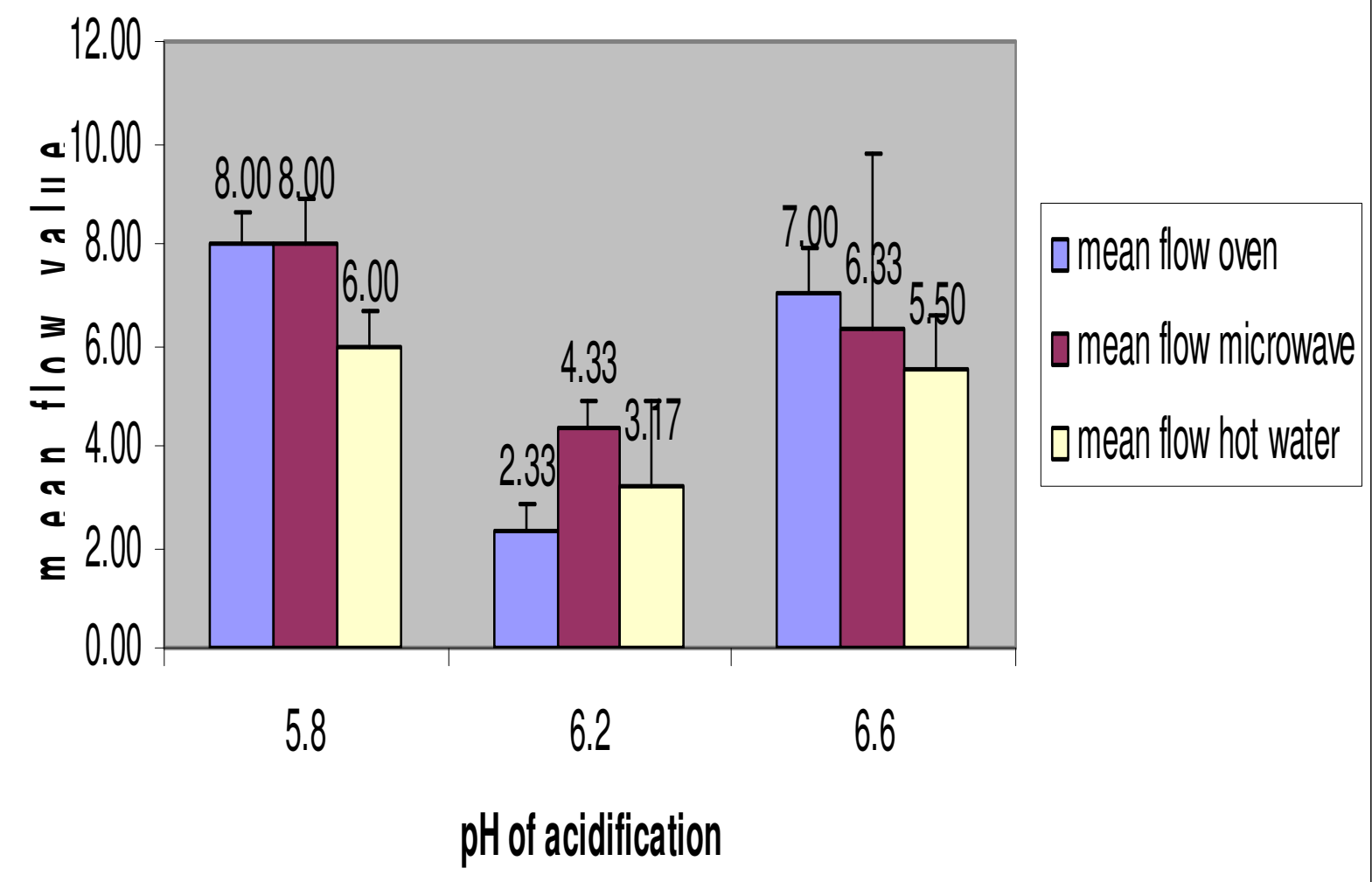

Figure 5.32 Effect of $\mathrm{pH}$ of acidification on mean flow value of HPDF manufactured from milk pasteurized at $161^{\circ} \mathrm{F} / 16 \mathrm{sec}$. (for 1 Standard Error, $\mathrm{n}=4$ ) 


\subsubsection{Analysis of textural properties}

Figures 5.33, 5.34, 5.35, 5.36, 5.37 and 5.38 again confirmed the effect of pasteurization condition and $\mathrm{pH}$ of acidification on texture of HPDF. The HPDF made from milk pasteurized at high temperature $\left(191^{\circ} \mathrm{F} / 16 \mathrm{sec}\right)$ was significantly harder than that of made from milk pasteurized at low temperature $\left(161^{\circ} \mathrm{F} / 16 \mathrm{sec}\right)$. This can be explained by loss of moisture in the HPDF during higher level of heat treatment. It is well established that higher moisture content food, at a given $\mathrm{pH}$ are less firm than their lower-moisture content counter parts. This has been attributed to the extent of swelling of casein submicelles with the increase in casein-to-moisture ratio. Similarly, HPDF made from milk coagulated at lower $\mathrm{pH}$ of acidification had a significant effect on the hardness. As the $\mathrm{pH}$ of coagulation decreases, hardness of HPDF increases. High $\mathrm{pH}$ weakens the protein bonds through charge repulsion, as the negative charges on casein molecules increase with $\mathrm{pH}$. The hydrophobic interactions, important for a stable casein matrix structure, are weakened by adsorption of water by proteins to solvate the ionic charges. In high-pH cheese, the absorption of water by protein limits the amount of water in matrix interstices. Also loss of miceller calcium during lower $\mathrm{pH}$ of coagulation affects the texture of HPDF. Thus, higher pasteurization condition coupled with lower $\mathrm{pH}$ of coagulation adds to the hardness of HPDF. 
Table 5.20 Effect of $\mathrm{pH}$ of acidification and heating condition on mean hardness, gumminess and chewiness of HPDF (sample size $n=3$ )

\begin{tabular}{|c|c|c|c|c|c|}
\hline batch & $\begin{array}{c}\mathrm{pH} \text { of } \\
\text { acidification }\end{array}$ & $\begin{array}{c}\text { heating } \\
\text { condition }\end{array}$ & $\begin{array}{c}\text { mean } \\
\text { hardness }(\mathrm{g})\end{array}$ & gumminess $(\mathrm{g})$ & chewiness(J) \\
\hline 1 & 5.8 & $161^{\circ} \mathrm{F} / 16 \mathrm{sec}$ & 5072.97 & 1849.80 & 5712.10 \\
\hline 2 & 6.2 & $161^{\circ} \mathrm{F} / 16 \mathrm{sec}$ & 3656.30 & 2334.63 & 9238.66 \\
\hline 3 & 6.6 & $161^{\circ} \mathrm{F} / 16 \mathrm{sec}$ & 1173.86 & 831.37 & 2051.22 \\
\hline 4 & 5.8 & $191^{\circ} \mathrm{F} / 16 \mathrm{sec}$ & 5510.13 & 1664.74 & 5700.03 \\
\hline 5 & 6.2 & $191^{\circ} \mathrm{F} / 16 \mathrm{sec}$ & 4963.38 & 2351.22 & 7830.42 \\
\hline 6 & 6.6 & $191^{\circ} \mathrm{F} / 16 \mathrm{sec}$ & 3448.86 & 2434.62 & 4518.98 \\
\hline
\end{tabular}




\section{Effect of pH and heating condition on texture}

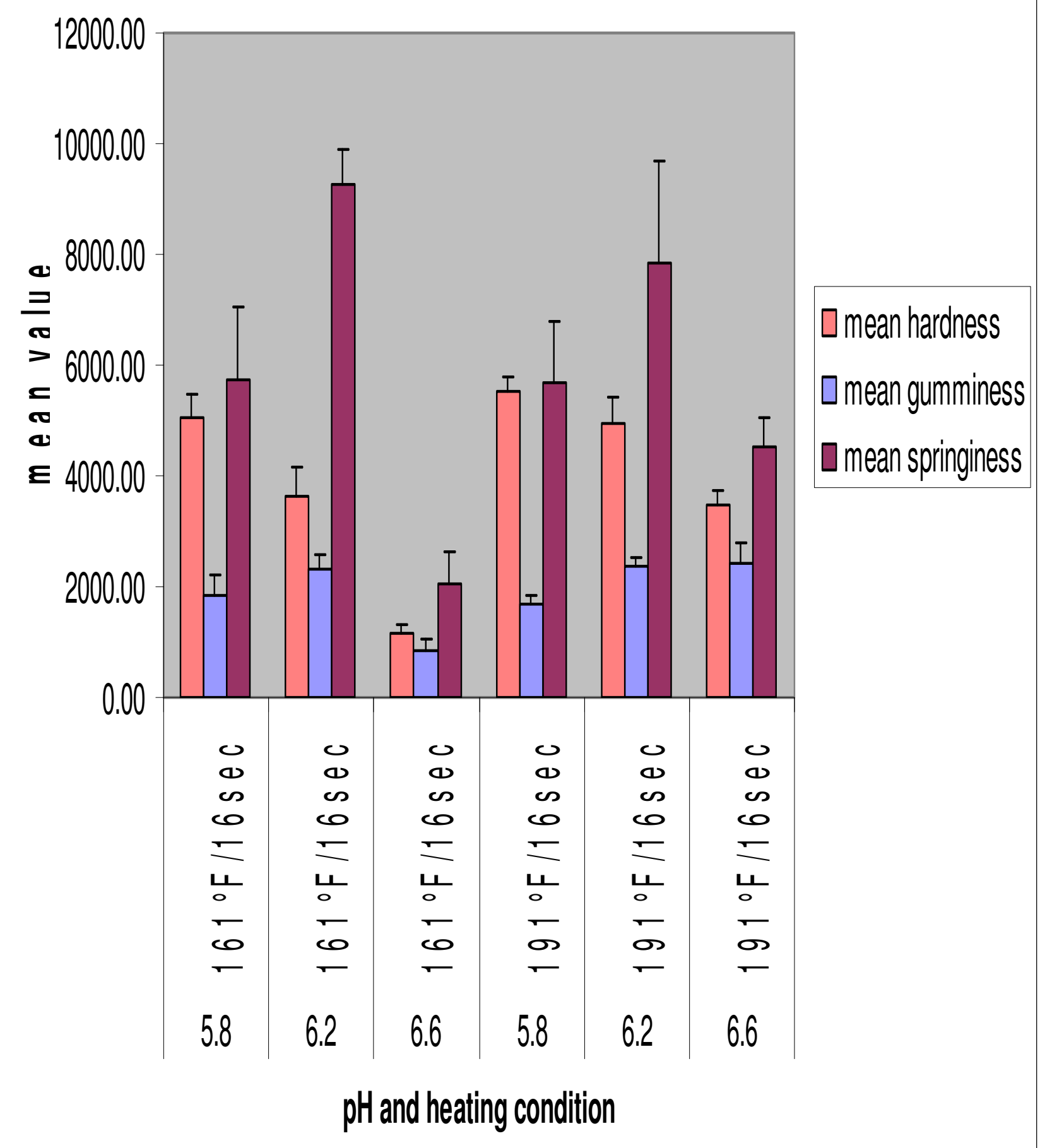

Figure 5.33 Effect of $\mathrm{pH}$ and heating condition on mean hardness, mean gumminess and mean springiness of HPDF (+1 Standard Error, sample size $n=3$ ) 
Table 5.21 Effect of $\mathrm{pH}$ of acidification and heating condition on mean cohesiveness and mean springiness of HPDF (sample size $n=3$ )

\begin{tabular}{|c|c|c|c|c|}
\hline batch & $\begin{array}{c}\mathrm{pH} \text { of } \\
\text { acidification }\end{array}$ & $\begin{array}{c}\text { Heating } \\
\text { condition }\end{array}$ & $\begin{array}{l}\text { mean } \\
\text { cohesiveness }\end{array}$ & $\begin{array}{l}\text { mean } \\
\text { springiness }\end{array}$ \\
\hline 1 & 5.8 & $161^{\circ} \mathrm{F} / 16 \mathrm{sec}$ & 0.76 & 3.42 \\
\hline 2 & 6.2 & $161^{\circ} \mathrm{F} / 16 \mathrm{sec}$ & 0.68 & 4.10 \\
\hline 3 & 6.6 & $161^{\circ} \mathrm{F} / 16 \mathrm{sec}$ & 0.75 & 2.82 \\
\hline 4 & 5.8 & $191^{\circ} \mathrm{F} / 16 \mathrm{sec}$ & 0.67 & 3.35 \\
\hline 5 & 6.2 & $191^{\circ} \mathrm{F} / 16 \mathrm{sec}$ & 0.72 & 3.30 \\
\hline 6 & 6.6 & $191^{\circ} \mathrm{F} / 16 \mathrm{sec}$ & 0.59 & 2.06 \\
\hline
\end{tabular}




\section{Effect of $\mathrm{pH}$ and heating condition on texture}

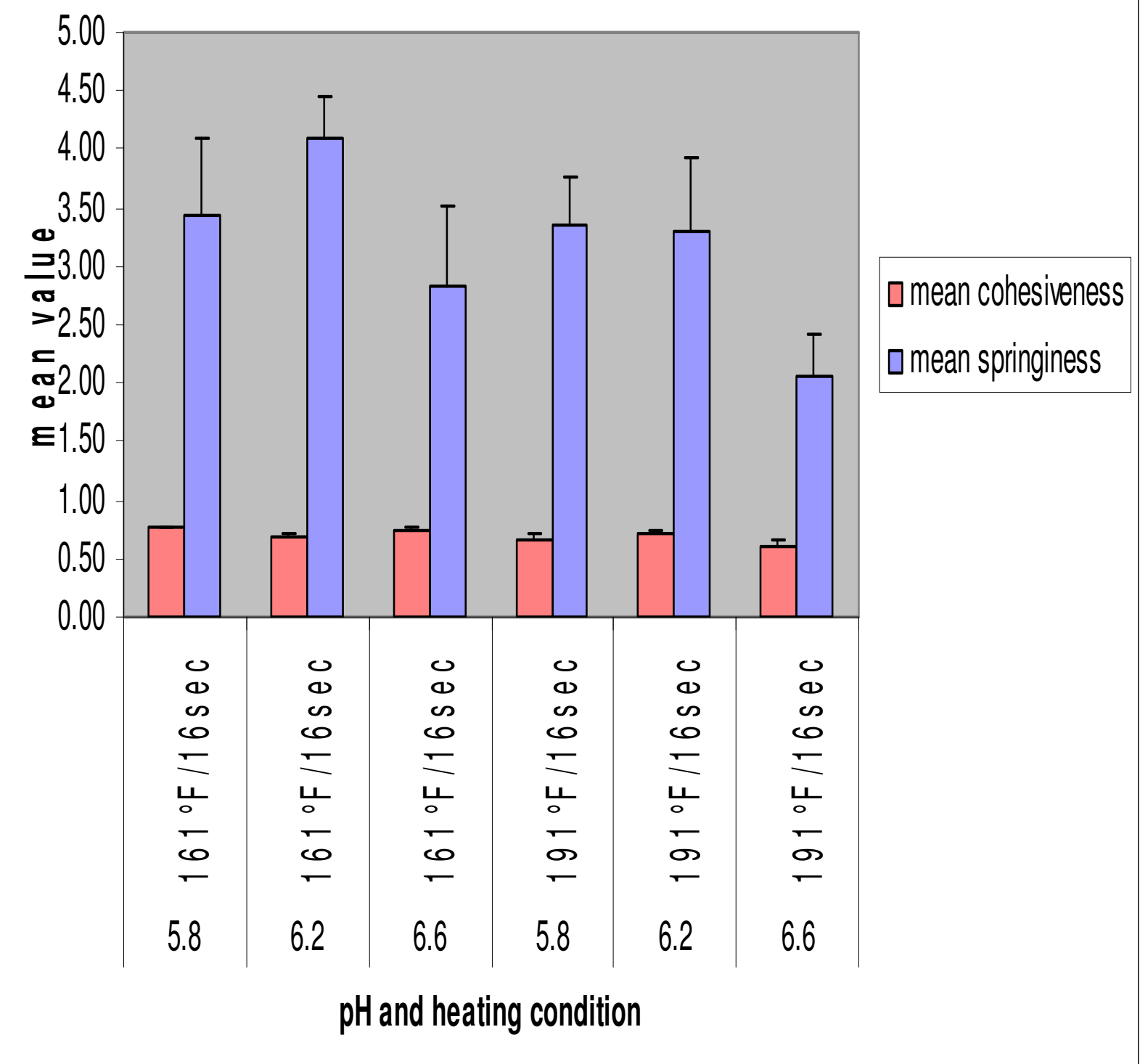

Figure 5.34 Effect of $\mathrm{pH}$ and heating condition on mean cohesiveness and mean springiness of HPDF (+1 Standard Error, sample size $n=3$ ) 


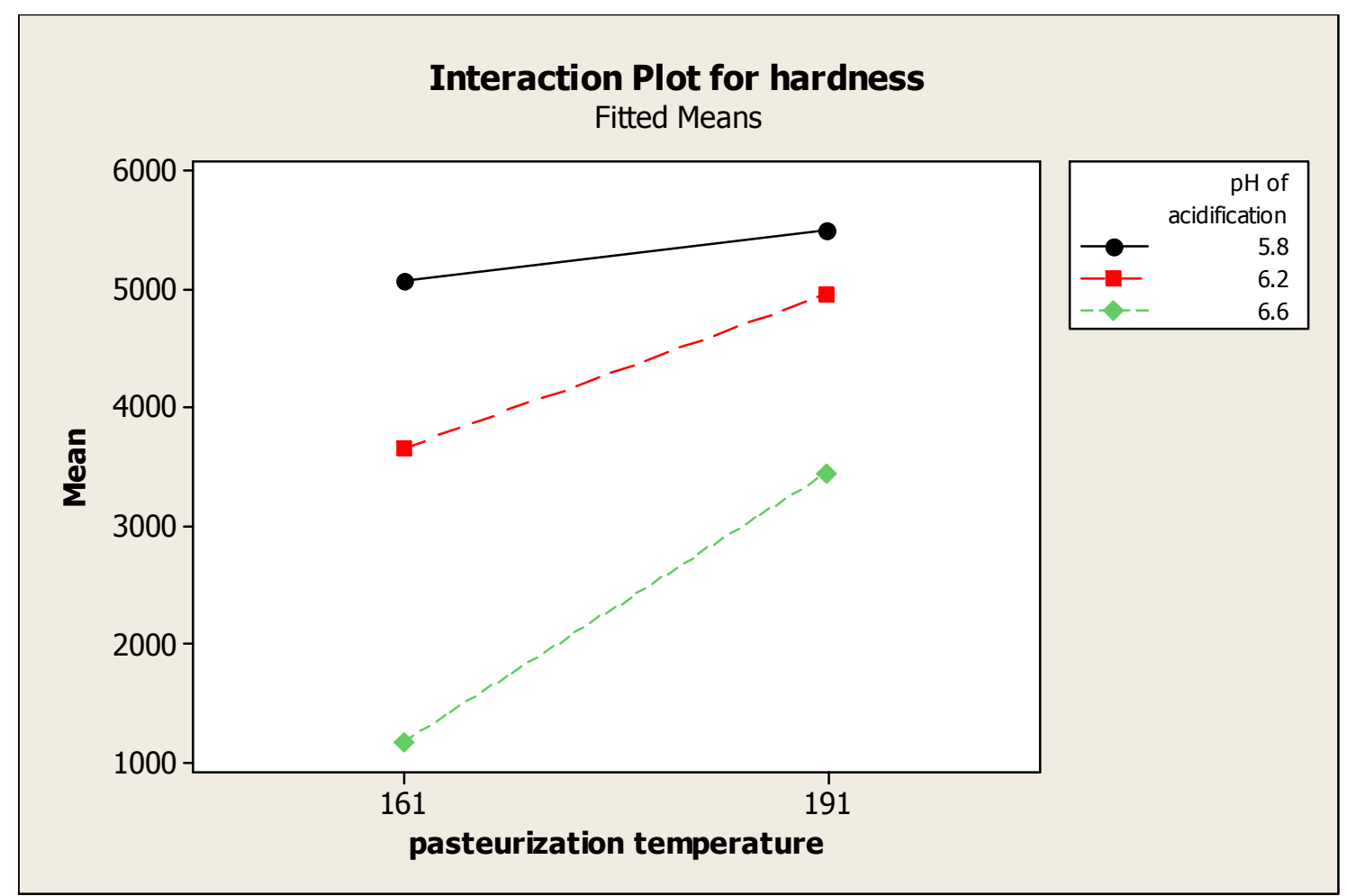

Figure 5.35 Interaction Plot for hardness vs. pasteurization condition and $\mathrm{pH}$ of acidification

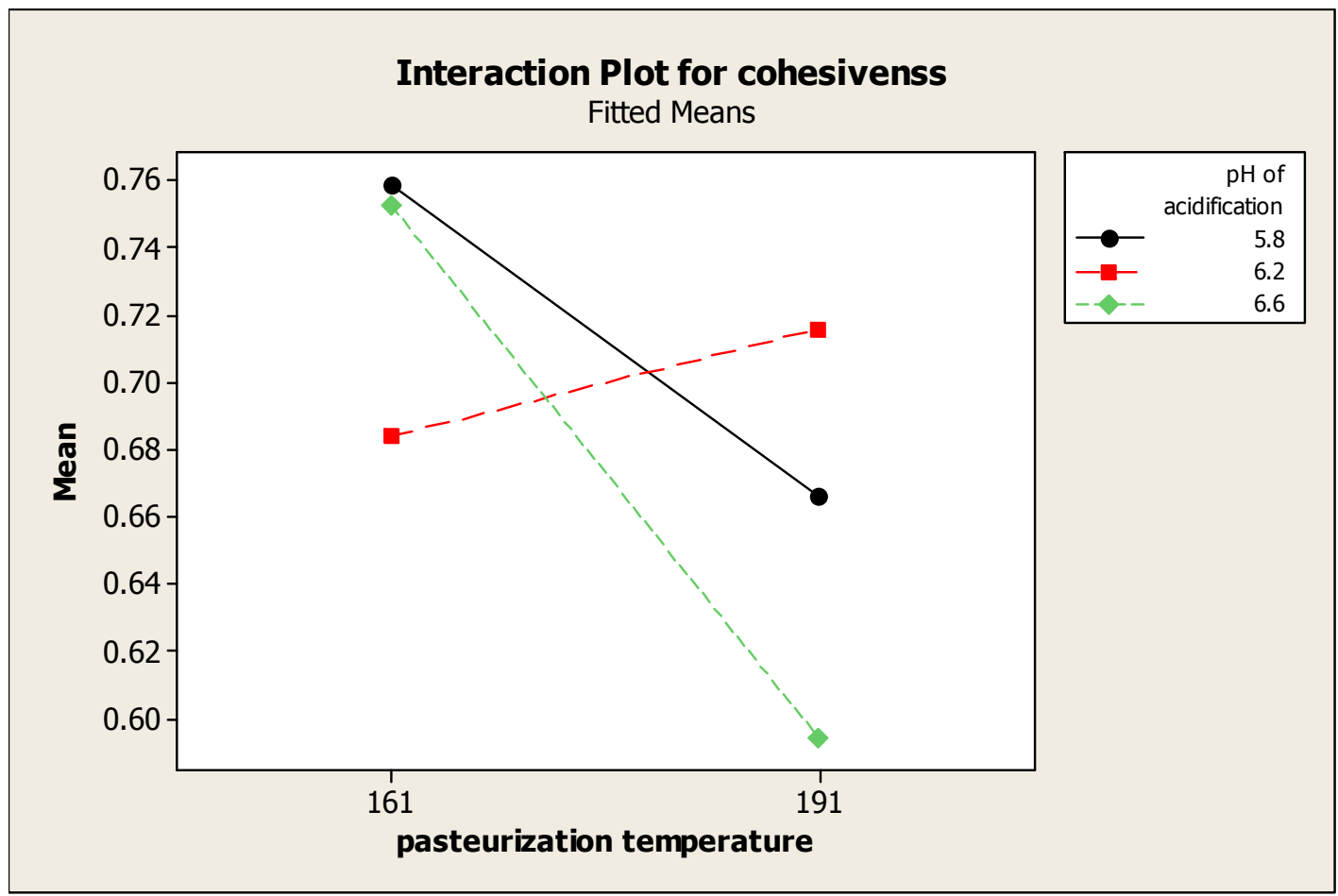

Figure 5.36 Interaction Plot for cohesivess vs. pasteurization condition and $\mathrm{pH}$ of acidification 


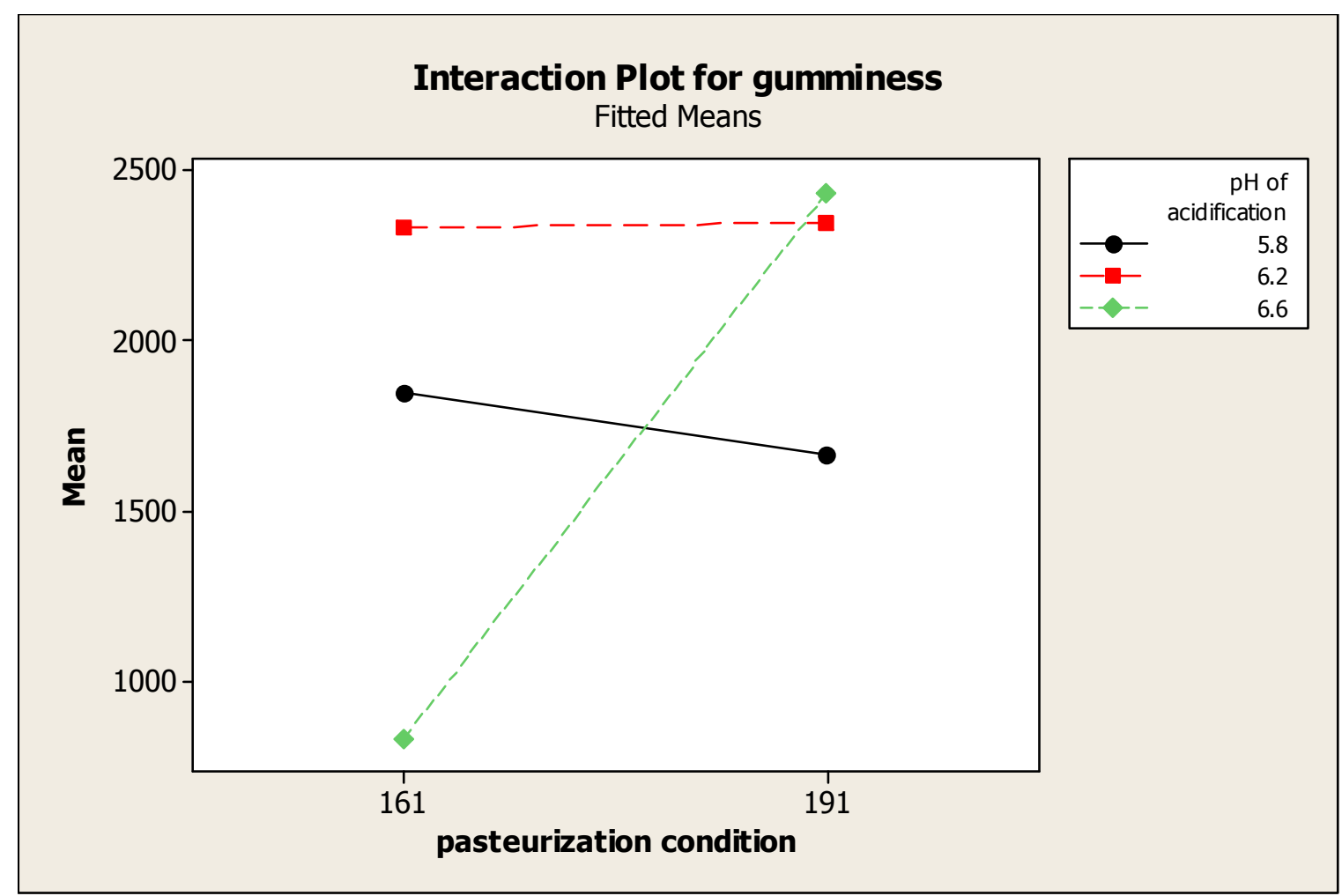

Figure 5.37 Interaction Plot for gumminess vs. pasteurization condition and $\mathrm{pH}$ of acidification

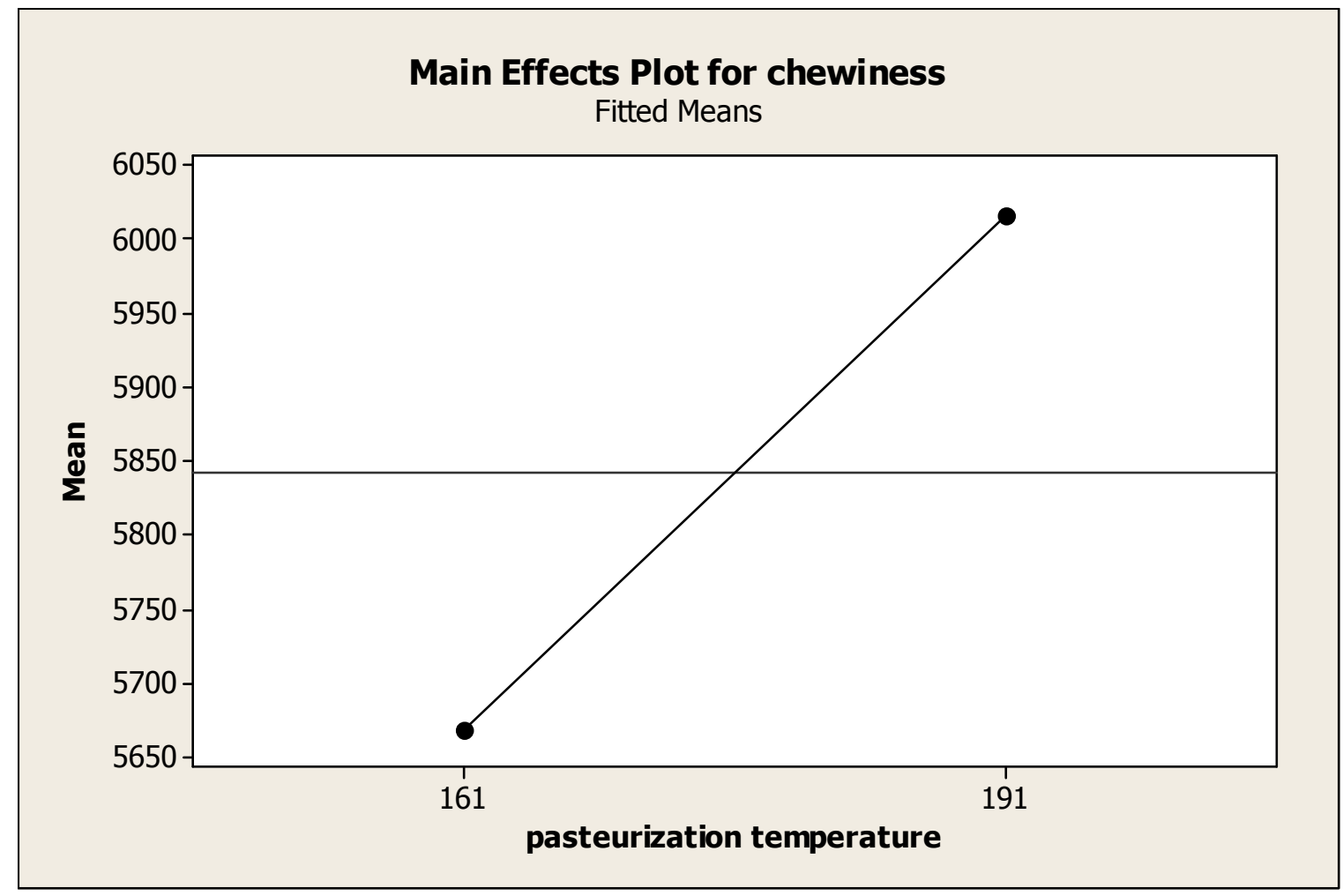

Figure 5.38 Main Effect Plot of chewiness vs. pasteurization temperature 


\subsection{Homogenization effect}

From preliminary findings of first stage of experiment, homogenization influenced moisture, protein and gumminess of HPDF (Table 5.4, 5.11). Further, comparing the HPDF texture with commercial tofu and tofu alternatives reveals that HPDF manufactured at $\mathrm{pH} 5.8$ and 6.2 was closest resembling the textural properties of extra firm and firm tofu. (Section 5.5).

Hence, the last stage of experiment consisted of more focused processing treatments. The treatments were two levels of homogenization conditions with two stage homogenization (2500 psi/500 psi) (yes/no) and two levels of acidification $(5.8,6.2)$.

\subsubsection{Compositional Analysis}

The HPDF was analyzed for fat, protein and moisture content and the results are presented in Table 5.23, Table 5.24 and Table 5.25.

\subsubsection{Fat Content}

From Table 5.23, the fat content was consistent to be in the range of $10.5-11.0 \%$ for HPDF. Neither homogenization nor $\mathrm{pH}$ of acidification of milk was significant for fat content of HPDF (Table 5.26).This was, in particular, surprising due to the effect of homogenization on redistribution of fat in milk and resultant HPDF. Homogenization decreases the size of fat globule size to less than $2 \mu$ due to which there is more fat recovery in the final product. Conventional two stage homogenization of milk increases yield of HPDF due to better fat recovery (Jana and Upadhyay, 1992). The surprising results of effect of homogenization on mean fat content may be due to limited batch size (4) of HPDF. However, the result was in line with the results obtained in the first stage of the experimentation on effect of homogenization on HPDF (Table 5.1) 


\subsubsection{Protein and moisture content}

From Table 5.24, the mean protein content of HPDF varied in the range of $27-32 \%$, which was in accordance with the results of first and second stage of experimentation. Mean protein content of HPDF manufactured at $\mathrm{pH} 5.8$ was significantly higher than the one that was manufactured at pH 6.2 (Figures 5.39, 5.40, Table 5.26). Also, there was an interaction between homogenization and $\mathrm{pH}$ of acidification of milk for mean protein content of HPDF as in Table 5.26. 
Table 5.23 Effect of homogenization on mean fat of HPDF (sample size $n=2$ )

\begin{tabular}{|c|c|c|c|c|}
\hline batch & Homogenization & $\begin{array}{c}\mathrm{pH} \text { of } \\
\text { acidification }\end{array}$ & $\begin{array}{c}\text { mean \% } \\
\text { fat }\end{array}$ & $\begin{array}{c}\text { Standard } \\
\text { error }\end{array}$ \\
\hline 1 & $\mathrm{~N}$ & 6.2 & 10.5 & 0.25 \\
\hline 2 & $\mathrm{Y}$ & 6.2 & 11 & 0.25 \\
\hline 3 & $\mathrm{Y}$ & 5.8 & 11 & 0.5 \\
\hline 4 & $\mathrm{~N}$ & 5.8 & 10.5 & 0.25 \\
\hline
\end{tabular}


Table 5.24 Effect of homogenization on mean protein of HPDF (sample size $n=2$ )

\begin{tabular}{|c|c|c|c|c|}
\hline batch & Homogenization & $\begin{array}{c}\mathrm{pH} \text { of } \\
\text { acidification }\end{array}$ & $\begin{array}{c}\text { mean \% } \\
\text { protein }\end{array}$ & $\begin{array}{c}\text { Standard } \\
\text { error }\end{array}$ \\
\hline 1 & $\mathrm{~N}$ & 6.2 & 27.04 & 0.28 \\
\hline 2 & $\mathrm{Y}$ & 6.2 & 29.05 & 0.18 \\
\hline 3 & $\mathrm{Y}$ & 5.8 & 29.21 & 0.45 \\
\hline 4 & $\mathrm{~N}$ & 5.8 & 31.44 & 0.19 \\
\hline
\end{tabular}


Table 5.25 Effect of homogenization on mean moisture of HPDF (sample size $n=2$ )

\begin{tabular}{|c|c|c|c|c|}
\hline Batch & Homogenization & $\begin{array}{c}\mathrm{pH} \text { of } \\
\text { acidification }\end{array}$ & $\begin{array}{l}\text { mean \% } \\
\text { moisture }\end{array}$ & $\begin{array}{l}\text { Standard } \\
\text { error }\end{array}$ \\
\hline 1 & $\mathrm{~N}$ & 6.2 & 56.11 & 0.21 \\
\hline 2 & $\mathrm{Y}$ & 6.2 & 55.07 & 1.14 \\
\hline 3 & $\mathrm{Y}$ & 5.8 & 53.76 & 0.34 \\
\hline 4 & $\mathrm{~N}$ & 5.8 & 53.76 & 1.29 \\
\hline
\end{tabular}


Table $5.26 \mathrm{p}$-values for test of significance for homogenization on mean moisture, protein and fat content

\begin{tabular}{|l|c|c|c|}
\hline Factors & mean & mean & mean \\
& moisture & protein & fat \\
\hline Homogenization & 0.571 & 0.727 & 0.791 \\
\hline $\mathrm{pH}$ of acidification & 0.061 & $\mathbf{0 . 0 0 0}$ & 0.791 \\
\hline homogenization $^{*} \mathrm{pH}$ of acidification & 0.566 & $\mathbf{0 . 0 0 0}$ & 0.791 \\
\hline
\end{tabular}

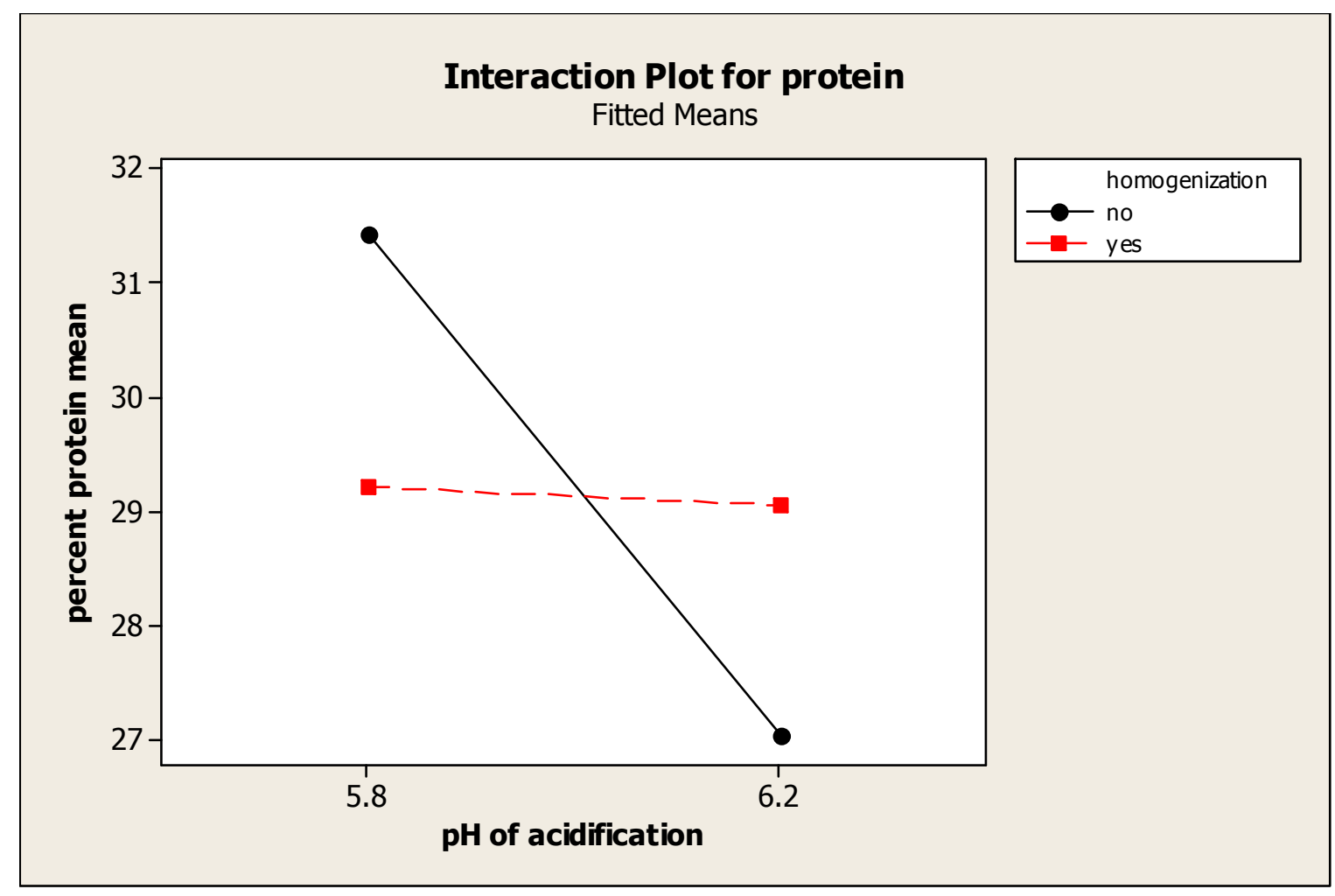

Figure 5.39 Interaction Plot for mean protein vs. homogenization and $\mathrm{pH}$ of acidification 


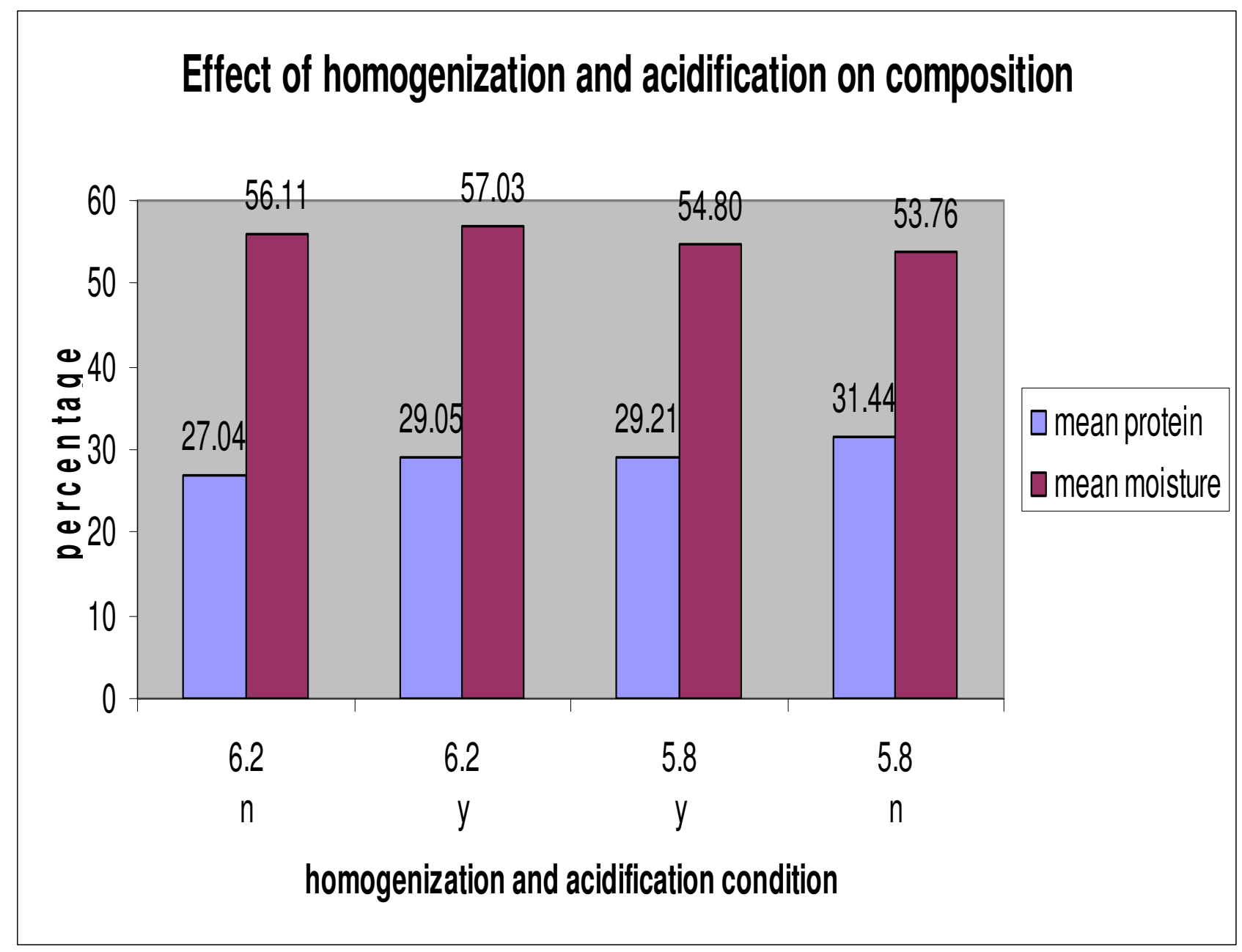

Figure 5.40 Effect of Homogenization and $\mathrm{pH}$ of acidification on mean protein and mean moisture percent of HPDF. (for +1 Standard Error, n=2) 


\subsubsection{Analysis of flow properties}

The HPDF was analyzed for flow properties and the 'flow value' under different heating conditions is presented in Tables 5.27, 5.28 and 5.29. Corresponding effect and graph are presented in Figures 5.41 and 5.42 respectively. Homogenization restricts the flowability of HPDF. Since all the milk for making HPDF was pasteurized at $191^{\circ} \mathrm{F}$ for $16 \mathrm{sec}$, (as per the experimental design of stage-3), none of the batches of HPDF showed flowability. Once again these results confirmed the prominent role of high heat treatment on restricting flow properties of HPDF. Effect of homogenization was overshadowed by this high heat treatment. However, from Table 5.30, pH of acidification had a significant role in restricting the flow properties of HPDF. In this case, lower $\mathrm{pH}$ of coagulation had the highest restriction of flowability.

Homogenization of milk for high protein food (like cheese) is not very common in the industry, although use of homogenized milk can increase the yield of final product (as seen in increase in moisture content in 5.4.1.2). Leliever et al., (1990) determined that homogenization at high pressures ( 6.7 MPa) adversely affects flowability. However, no such adverse effects were observed when the milk was homogenized at lower pressures $(\sim 400 \mathrm{kPa})$. In this experiment the two stage of homogenization with first stage 2000 psi ( 13.8 MPa) and second stage 500 psi (3.5 Mpa) should be significant to restrict the flowability of HPDF. The non-significance of homogenization on flowability in this experiment may be due to limited sample size (4). 
Table 5.27 Effect of homogenization and $\mathrm{pH}$ of acidification on mean flow in oven of HPDF (for sample size $n=4,1$ flow unit=10 mm flow, flow unit $<1$ is considered as flow resistance)

\begin{tabular}{|c|c|c|c|c|}
\hline batch & Homogenization & $\begin{array}{c}\mathrm{pH} \text { of } \\
\text { acidification }\end{array}$ & $\begin{array}{c}\text { Mean flow } \\
\text { unit oven }\end{array}$ & $\begin{array}{c}\text { Standard } \\
\text { error }\end{array}$ \\
\hline 1 & No & 6.2 & 0.00 & 0.17 \\
\hline 2 & Yes & 6.2 & 0.17 & 0.17 \\
\hline 3 & Yes & 5.8 & 0.00 & 0.08 \\
\hline 4 & No & 5.8 & 0.00 & 0.08 \\
\hline
\end{tabular}


Table 5.28 Effect of homogenization and $\mathrm{pH}$ of acidification on mean flow in microwave of HPDF (for sample size $\mathrm{n}=4,1$ flow unit $=10 \mathrm{~mm}$ flow, flow unit $<1$ is considered as flow resistance)

\begin{tabular}{|c|c|c|c|c|}
\hline batch & Homogenization & $\begin{array}{c}\mathrm{pH} \text { of } \\
\text { acidification }\end{array}$ & $\begin{array}{c}\text { Mean flow unit } \\
\text { microwave }\end{array}$ & Standard error \\
\hline 1 & No & 6.2 & 0.33 & 0.21 \\
\hline 2 & Yes & 6.2 & 0.50 & 0.22 \\
\hline 3 & Yes & 5.8 & 0.67 & 0.21 \\
\hline 4 & No & 5.8 & 1.00 & 0.17 \\
\hline
\end{tabular}


Table 5.29 Effect of homogenization and $\mathrm{pH}$ of acidification on mean flow in hot water of HPDF (for sample size $\mathrm{n}=4,1$ flow unit $=10 \mathrm{~mm}$ flow, flow unit $<1$ is considered as flow resistance)

\begin{tabular}{|c|c|c|c|c|}
\hline batch & Homogenization & $\begin{array}{c}\mathrm{pH} \text { of } \\
\text { acidification }\end{array}$ & $\begin{array}{c}\text { Mean flow unit } \\
\text { hot water }\end{array}$ & $\begin{array}{c}\text { Standard } \\
\text { error }\end{array}$ \\
\hline 1 & No & 6.2 & 0.08 & 0.08 \\
\hline 2 & Yes & 6.2 & 0.00 & 0.08 \\
\hline 3 & Yes & 5.8 & 0.00 & 0.08 \\
\hline 4 & No & 5.8 & 0.08 & 0.08 \\
\hline
\end{tabular}


Table 5.30 p-values of test of significance of mean flowing of HPDF in oven, microwave and hot water at different acidification and homogenization conditions.

\begin{tabular}{|l|r|r|r|}
\hline Factors & \multicolumn{1}{|c|}{$\begin{array}{c}\text { Mean flow } \\
\text { in oven }\end{array}$} & \multicolumn{1}{c|}{$\begin{array}{r}\text { Mean flow in } \\
\text { microwave }\end{array}$} & \multicolumn{1}{c|}{$\begin{array}{r}\text { Mean flow in } \\
\text { hot water }\end{array}$} \\
\hline Homogenization & 0.329 & 0.660 & 0.329 \\
\hline $\mathrm{pH}$ of acidification & 0.329 & $\mathbf{0 . 0 3 7}$ & 0.329 \\
\hline Homogenization*acidification & 0.329 & 0.195 & 0.329 \\
\hline
\end{tabular}

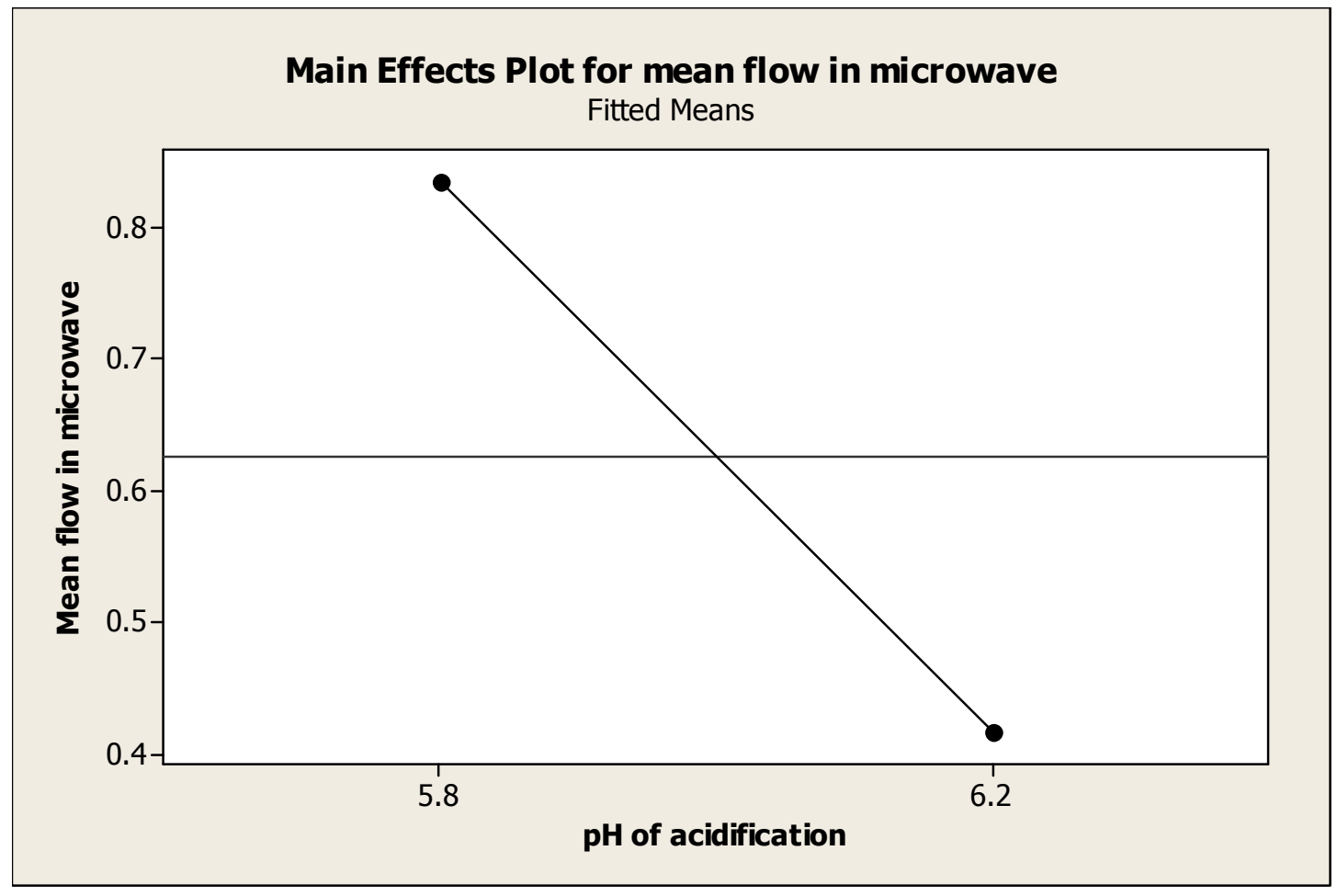

Figure 5.41 Main Effects Plot for mean flow in microwave vs. pH of acidification 


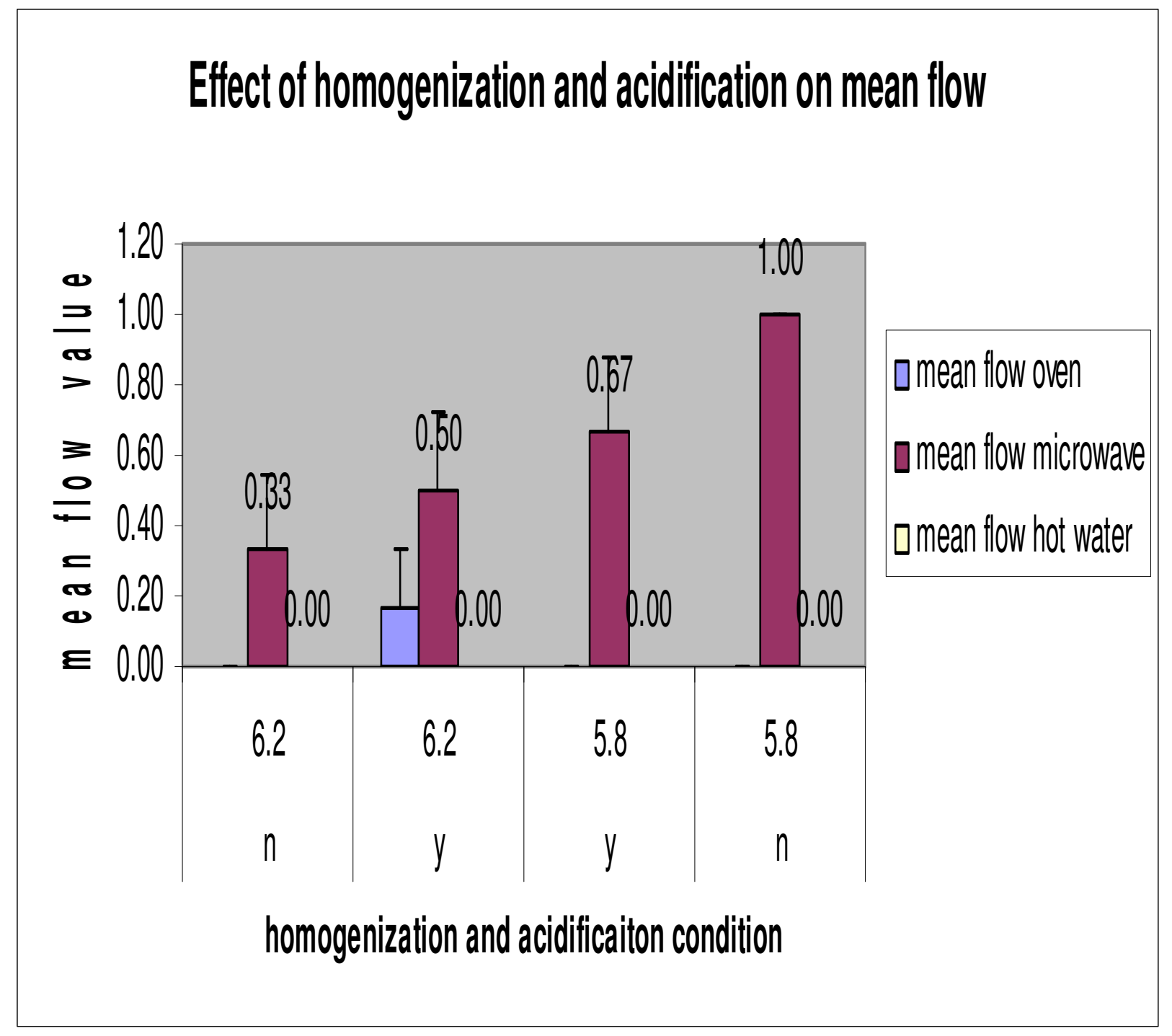

Figure 5.42 Effect of homogenization and $\mathrm{pH}$ of acidification on mean flow value of HPDF (for +1 Standard Error, $n=4$ ) 


\subsection{Comparisons of HPDF with commercial tofu and halloumi}

Figure 5.43 compares of hardness of HPDF with other commercial products. There were similarities between hardness of extra firm tofu and HPDF manufactured at $\mathrm{pH} 5.8$ and 6.2. The wide difference of hardness of HPDF and commercial halloomi may be due to higher fat content (25-30\%) and difference in $\mathrm{pH}$ of coagulation. Hardness of all the other types of tofu was lower than HPDF. The difference in hardness has further been confirmed by lower p-value (0.01) associated with hardness versus type of commercial product. The difference may be attributed to the difference in chemical composition, chemical profile and manufacturing procedure of these products. The protein associated with hardness of the tofu products are soy proteins mainly $7 \mathrm{~S}$ and $11 \mathrm{~S}$. The difference in manufacturing procedure includes varieties of soybeans used to manufacture, initial solid content of soy milk, use of coagulant, coagulation temperature, coagulation $\mathrm{pH}$, moisture content, loss of soluble matters during pressing and washing of soybean curd. (Deman et al., 1987). In case of commercial halloumi cheese (used in this study), the history of type of milk used is not known, but traditionally, caprine (goat/sheep) milk is used to manufacture commercial halloumi which is different in chemical composition (in terms of quality and quantity) from cow milk. This may be one of the reasons for difference in hardness of HPDF and commercial halloumi. 


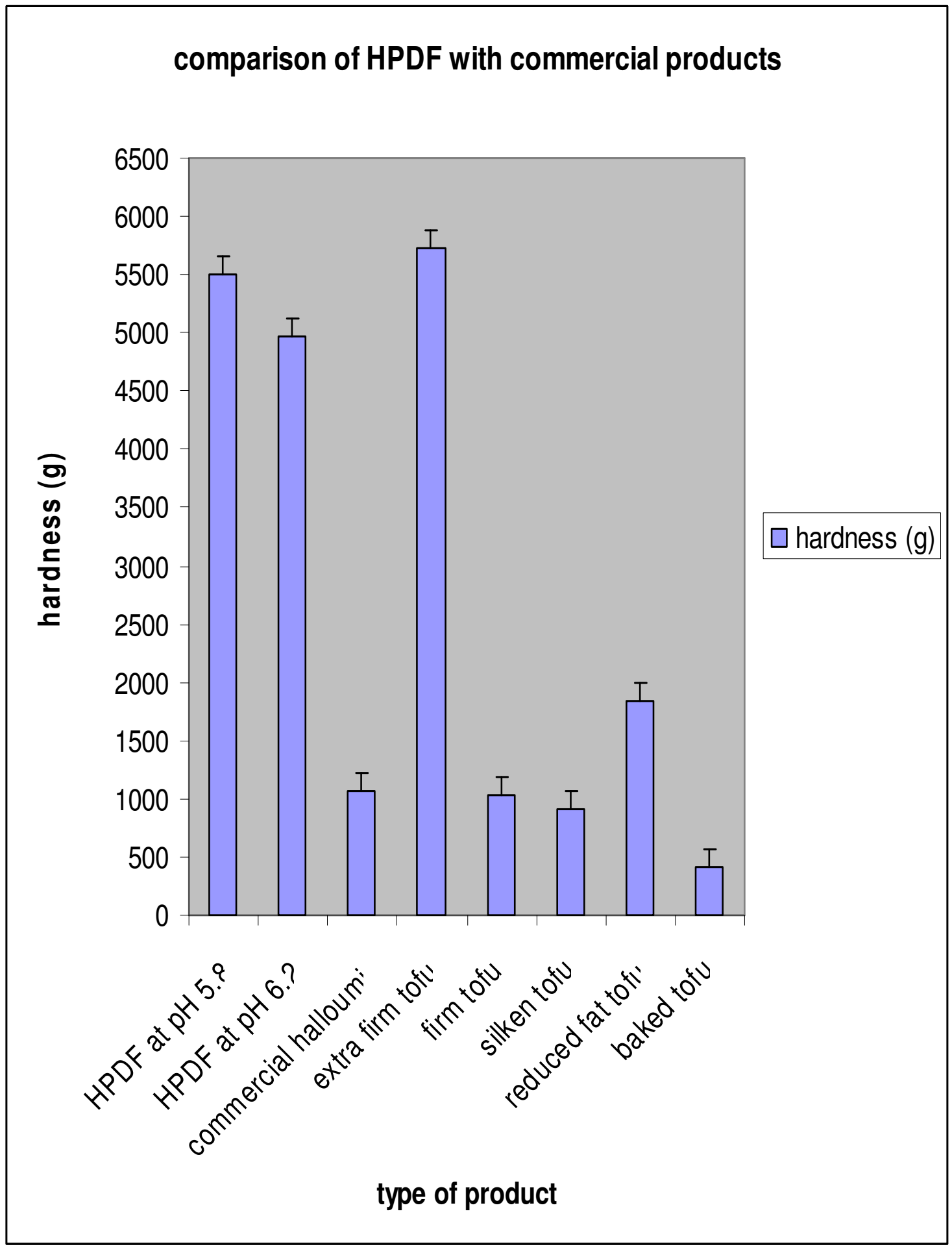

Figure 5.43 Comparison of HPDF with commercial protein rich sources (sample size $n=3$ ) 


\subsection{Limited focus group survey on cooking application}

The results of the Limited focus group survey on three cooking applications-namely baking, soup type cooking and stir-frying are presented in Figure 5.44. Out of 36 opinions collected in the survey, 15 opinions preferred HPDF over tofu in one cooking application, whereas 21 opinions preferred tofu over HPDF. The disliking of HPDF was mainly because of its higher firmness and chewiness over tofu. The liking of HPDF was because of its flavor over bland flavor of tofu.

One of the factors influencing preference of tofu over HPDF was assumed to be prior familiarity of panelist with the type of product. The individual break up of preference versus familiarity with product is shown in Figure 5.45. All the 21 panelists, who preferred tofu over HPDF, have tried one or more of the three tofu products before. Out of the 29 panelist who tried tofu products before, 8 preferred HPDF over tofu mainly because of its flavor and better absorption abilities. The 7 panelists who never tried any tofu products before preferred HPDF over tofu. The pvalue $(0.317)$ and $95 \%$ tukey confidence interval $(0.407,0.745)$ for chi-square test associated with the influence of familiarity over the preference was suggesting that prior familiarity with one or more of tofu products does influence the preference for tofu. The consumer perception on tofu recipes were subconsciously influencing the preference of panelists (who are familiar with baked tofu, stir fried tofu and miso soup) and they were preferring tofu over HPDF. This finding is interesting in determining potential consumer base for HPDF. The target customer base, who potentially will favor HPDF, is primarily the non-tofu eater consumers. 


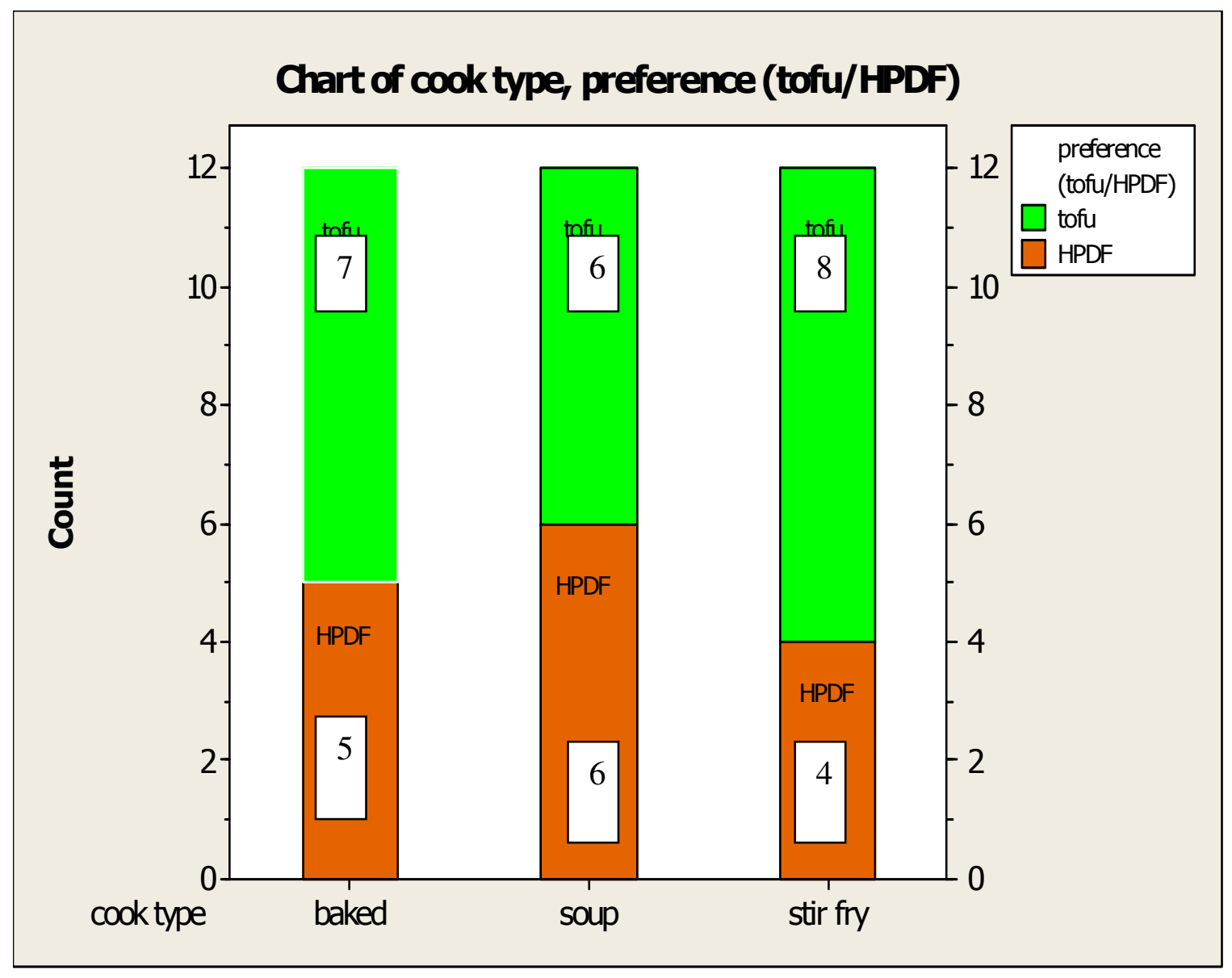

Figure 5.44 Consumer preference of tofu/HPDF on baking, soup-type and stir-frying application (sample size $n=12$ ) 


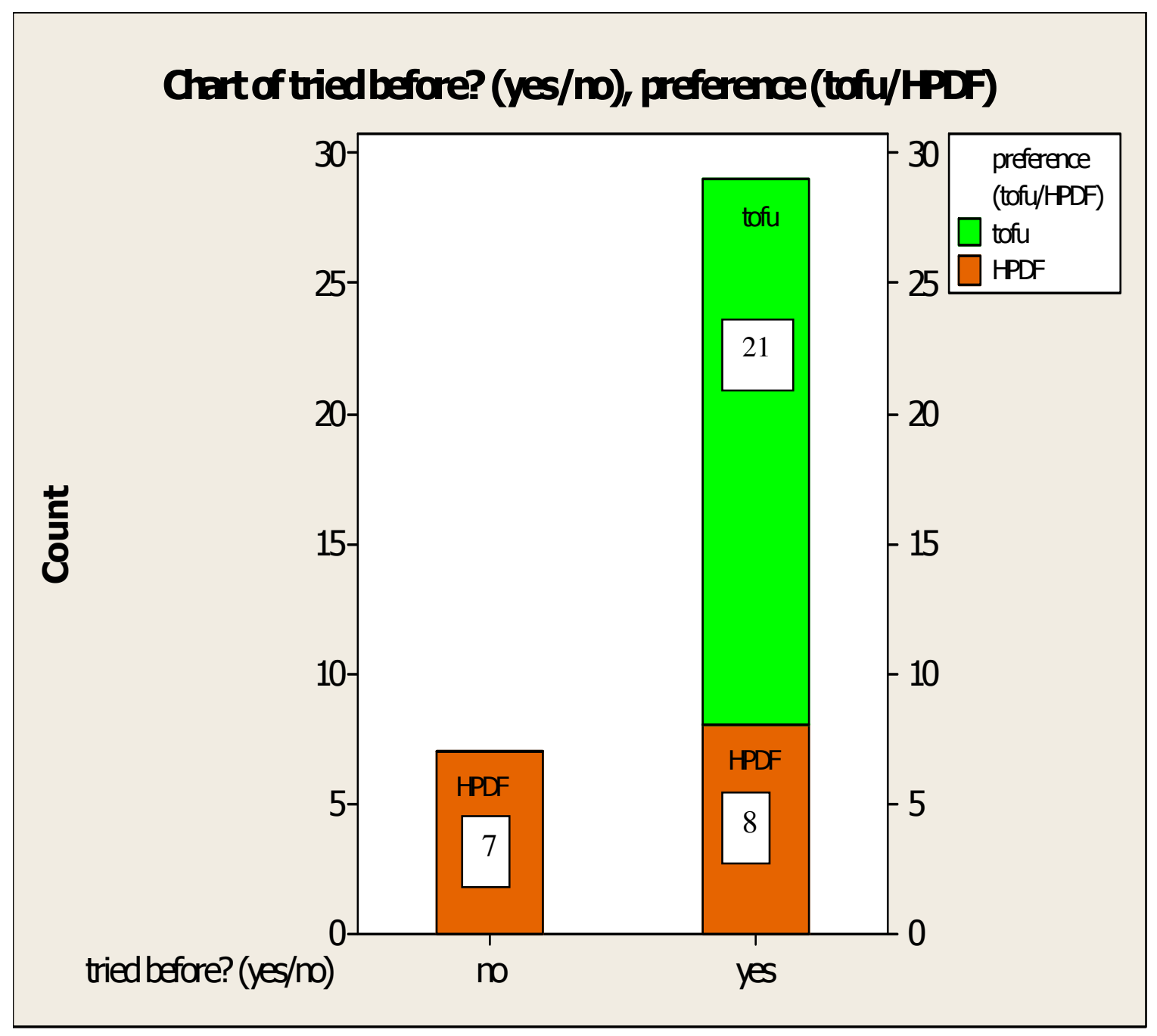

Figure 5.45 Influence of consumer's familiarity of recipe over preference (sample size $n=36$ ) 


\subsection{Conclusion and Significance}

The mean fat, protein and moisture content of HPDF were in the range of $10.5-11 \%, 26-34 \%$ and $47-54 \%$ respectively. All three processing conditions affected the composition of HPDF significantly. High pasteurization condition $\left(191^{\circ} \mathrm{F} / 16 \mathrm{sec}\right)$ significantly increased the protein content and decreased the moisture content of HPDF. As $\mathrm{pH}$ of acidification increases, mean protein content of HPDF increases significantly. Homogenization increased the moisture content and decreased protein content of HPDF significantly.

Flow properties of HPDF were significantly affected by all the processing treatments with pasteurization condition as the most significant treatment. Milk with higher pasteurization condition $\left(191^{\circ} \mathrm{F} / 16 \mathrm{sec}\right)$ yielded the HPDF with maximum flow resistance under oven, microwave and hot water. The second most significant processing treatment after pasteurization condition affecting flow properties was $\mathrm{pH}$ of coagulation of milk with low $\mathrm{pH}$ of coagulation (5.8) yielding HPDF with significant flow resistance. At $191^{\circ} \mathrm{F} / 16 \mathrm{sec}$ and $\mathrm{pH}$ of coagulation 5.8, the flowability of HPDF was least under oven, microwave and hot water. Given the same processing conditions, the flowability of HPDF was maximum under microwave, followed by oven and hot water. The effect of homogenization on flowability of HPDF was not significant.

The texture profile analysis showed that texture of HPDF was significantly affected by all the three processing parameters. The primary textural properties affected were hardness, gumminess and chewiness. Milk coagulated at high pasteurization condition $\left(191^{\circ} \mathrm{F} / 16 \mathrm{sec}\right)$ yielded HPDF with maximum hardness. At $\mathrm{pH}$ of acidification 5.8, the hardness of HPDF was highest. The hardness decreases as $\mathrm{pH}$ of coagulation increases.

There was a significant difference between the hardness of HPDF and that of tofu and halloumi. The hardness of HPDF manufactured at pH 5.8 and 6.2 was very close to that of extra firm 
tofu. The Limited focus group survey of food application of HPDF indicated that consumer preference was highly influenced by prior familiarity of the consumer with the product. The main reason for liking of recipes involving HPDF was primarily the 'milky' flavor of HPDF compare to blend flavor to tofu, whereas the reason for non-liking of HPDF was its foreign taste, excessive hardness and chewiness over tofu.

From the findings of the experiment, it is clear that a high protein food, which has potential to be part of day to day human diet and which can be used as dairy based tofu alternative can be very well manufactured by optimizing processing condition (pasteurizing milk at $191^{\circ} \mathrm{F} / 16$ sec and coagulating at $\mathrm{pH}$ 5.8) and using the approach similar to manufacture of halloumi cheese. 


\subsection{Limitation and Future Research}

1. The shelf life of the HPDF was assumed to be fairly low due to its high $\mathrm{pH}(>6.0)$, but understanding the microbial quality of the HPDF and conduction a shelf life study will be beneficial to guide the consumer about proper storage temperature and time.

2. Flavor analysis of HPDF versus commercial protein rich products like tofu will be an interesting to substantiate the evidence that the dairy flavor of HPDF can be very well marketed against the 'bland' flavor of tofu.

3. Throughout the study, the HPDF was vacuum packed in polyethylene bags. Developing proper packaging material, which will preserve the flavor and texture of HPDF without compromising its shelf life under storage condition will be an interesting study.

4. To enhance the marketability of HPDF, emulating the texture of meat products like hamburger patties, chicken breast, turkey or bacon strip will be an interesting to develop veggie alternatives of all these products. 


\subsection{References}

Anema, S.G., Li, Y. (2003). Effect of pH on the association of denatured whey proteins with casein micelles in heated reconstituted skim milk. Journal of Agricultural and Food Chemistry 51:16401646.

Ang E.T.(1996). Delightful Tofu Cooking. Miso soup with vegetables. Delightful tofu cooking. 47.

Anifantakis E.M. and Kaminarides S.E. (1982) Contributions to the study of Halloumi cheese made from cows milk. Journal of Agriculture Research 6:119-127.

Anifantakis, E.M., Kaminarides, S.E. (1982). Contribution to the study of Halloumi cheese made from cow's milk. Journal of Agricultural Research 6:119-127.

Anifantakis, E.M., Kaminarides, S.E. (1983). Contribution to the study of Halloumi cheese made from sheep's milk. Australian Journal of Dairy Technology 58:29-31.

Arnott D.R., H.A. Morris and W.B. Combs. (1957). Effect of certain chemical factors on the flowing quality of process cheese. Journal of Dairy Science 40:957.

Bogenrief D.D. and N.F. Olson. (1995). Hydrolysis of casein increases Cheddar cheese flowability. Milchwissenschaft 50(12):678.

Bourne M.C. (1968). Texture profile of ripened pears. Journal of food sci. 33:223

Bourne, M.C. (1978). Texture profile analysis. Food Technology. 32,62-66.

Bourne, M.C. and Comstock S.H.(1981).Effect of degree of compression on texture profile parameters. Journal of Texture Studies 12:201

Bourne M.C. (1982). Food textures and viscosity : concept and measurement. New York : Academic Press.Canadian Institute Food Science Technology Journal. 18:133-136.

Chandan, R.C.(1991). Cheeses made by direct acidification, in Feta and related cheeses, Robinson, R.K. and Tamime, A.Y., eds, Ellis Horwood, New York. pp 229-252.

Chang KC.(2002). Isoflavones from soybean and soyfoods. In:Shi J, Mazz J, Maguer ML, editors. Functional foods: biochemical and processing aspects, Vol. II Functional foods and nutraceutical series. New York: CRC Press. P 39.

Chang KC.(2006). Chemistry and technology of tofu making. In: Hui YH, editor. Handbook of food science, technology and engineering. Vol. IV. Food technology and food processing. Boca Raton, Fla. CRC press. 171.1

Coppock, J.B.M.(1974). Soy Proteins in foods : retrospect and prospect. J. Am. Oil Chem. Soc. 51:59A 
Dalgleish, D.G. and Law, A.J.R.(1988) pH-induced dissociation of casein micelles. 1. Analysis of liberated caseins. Journal of Dairy Research 55:529-538.

Dannenberg, F., and Kessler, H.G.(1988). Reaction kinetics of the denaturation of whey proteins in milk. Journal of Food Science, 53:258-263.

De S. (1998). Outlines of Dairy Technology, Oxford University Press, Oxford.

Deman, J.M., L. Deman and S. Gupta (1987). Texture and microstructure of soybean curd (tofu) as affected by different coagulants. Food Microstructure 5(1):83

Di Luccia A., Ledda L., Moio L., Chianese L., Nicolai M.A., Spagna M.S. (1994). Quality control of Ricotta cheese based on protein composition. Italian Journal of Food Science 6 (2) p. 167-183. Pinerollo, Italy.

Doi H., Ideno S., Huang K, Ibuki F. and Kanamori, M. (1983). Gelation of the complex between $\kappa-$ casein and $\beta$-lactoglobulin. Journal of Nutrition Science and Vitaminology 29:679- 689.

Elfagm, A.A., and Wheelock, J.V. (1977). Effect of heat on $\alpha$-lactalbumin and $\beta$-lactoglobulin in bovine milk, Journal of Dairy Research, 44:367-371.

Escueta, E.E, Bourne M.C. and Hood L.F. (1986). Effect of boiling treatment of soymilk on the composition, yield, texture and sensory properties of tofu. Canadian Journal of Food Science and Technology 19:53

Farkye, N.Y. and Lee, F. (1998). Flow controlled cheese and process of making. California Polytechnic State University, US patent: 5,766,657.

Farkye, N.Y. and Prasad B.B. (1995). California Cooking Cheese. US patent \# 5,573,806.

Fox, P.F. (1981) Heat induced changes in milk preceding coagulation. Journal of Dairy Science 64:2127-2137.

Friedman, H.H., Whitney J.E. and Szczesniak A.S. (1963). The texturometer : a new instrument for objective texture measurement. Journal of food science 28:390-396.

Furukawa T., Ohta S. and Yamato A. (1979). Texture-structure relationships in heat induced soy protein gels. Journal of Texture Studies. 10:333.

Guinee T.P., Pudja P.D. and Farkye N.Y. (1993). Fresh acid-curd cheese varieties. Cheese: Chemistry, Physics and Microbiology. Elsevoer Academic Press, UK.

Gandhi A.P. and Bourne M.C. (1988) Effect of Pressure and storage time on texture profile parameters of Soybean Curd (tofu). Journal of Texture studies. 19(2): 137-142. 
Gunasekaran S., Hwang C.H. and S. Ko. (2002). Cheese flow/flow measurement methods-recent developments. Australian Journal of Dairy Technology 57(2):128.

Gupta S.K., Karahadian C. and Lindsay R.C. (1984). Effect of emulsifier salts on textual and flavor properties of processed cheese. Journal of Dairy Science 67:764.

Harvey, C.D., Morris H.A., and Jenness R. (1982). Relation between flowing and textural properties of process Cheddar cheese. Journal of Dairy Science 65:2291.

Hill, A.R., Bullock D.H. and Irvine, D.M.(1982) Manufacturing parameters of Queso Blanco made from milk and recombined milk. Canadian Institute Food Science Technology Journal 15:47-53.

Horne, D.S., Banks, J.M., Leaver, J. and Law, A.J.R. (1994) Dynamic mechanical spectroscopy of Cheddar cheese, in Cheese Yield and Factors Affecting its Control, Special Issue 9402, International Dairy Federation, Brussels, pp. 507-512.

Hou HJ, Chang KC. (2004) Storage condition affect soybean color, chemical composition and tofu qualities. J Food Proc Preser 28:473.

http://www.dietaryfiberfood.com/food-protein-sources.php

http://www.everydiet.org/articles/protein.htm

Imoto, E.M. , C.H.Lee, and C. Rha. (1979) Effect of compression ratio on the mechanical properties of cheese. Journal of Food Science 44:343

Jana, A.H. and Upadhyay, K.G. (1992) Homogenization of milk for cheese making- a review. Australian Journal of Dairy Technology. 47:72-79.

Jang, H.D., and Swaisgood, H.E. (1990) Disulfide bond formation between thermally denatured $\beta$ lactoglobulin and $\kappa$-casein in casein micelles. Journal of Dairy Science 73:900-904.

Kalab, M. and Modler, H.W. (1985). Development of microstructure in a cream cheese based on Queso Blanco cheese. Food Microstructure 4:89-98.

Kaminarides S., Rogoti E. and Malatou H. (2000). Comparison of the characteristics of halloumi cheese made from ovine milk, caprine milk or mixtures of these milks. International Journal of Dairy Technology. 53(3):100-105.

Kosikowski, F.V.(1967). The making of Ricotta cheese. Proc. $4^{\text {th }}$ Annual Marschall Invitational Italian Cheese Seminar, Madison, WI pp.1-7.

Kosikowski, F.V. (1977) Cheese and Fermented Milk Foods, $2^{\text {nd }}$ ed., 404-406. Ann Arbor MI: Edwards Bros., Inc. 
Langley, K.R. and R.J. Marshall. (1993) Jaw movement during mastication of fibrous and nonfibrous composite foods by adult subjects. Journal of Texture Studies 9:371.

Law, A.J.R. and Leaver, J. (1999) Factors affecting the heat denaturation of whey proteins in cow's milk. International Dairy Journal 9:407-408.

Law, A.J.R., Horne, D.S., Banks, J.M., and Leaver J. (1994) Heat induced changes in whey proteins and caseins. Milchwissenshaft 49:125-129.

Lelievre, J. ,Shaker r. and Taylor, M.W. (1990) The role of homogenization in the manufacture of Halloumi and Mozzarella cheese from recombined milk. Journal of Society of Dairy Technology 43(1): 21-24.

Lim B.T., Deman J.M., Deman L, Buzzell R.I. (1990) Yield and quality of tofu as affected by soybean and soymilk characteristics: calcium sulfate coagulation. J Food Science 55:1088

Lucey, J.A. , Tamehana M., Munro P.A. and Singh H.(1999). Effect of interactions between denatured whey proteins and casein micelles on the formation and rheological properties of acid skim milk gels. Journal of Dairy Research 65:555-567.

Lucey, J.A., Teo, C.T., Munro, P.A. and Singh, H. (1998) Microstructure, permeability and appearance of acid gels made from heated skim milk. Food Hydrocolloid 12:159-165.

Messina M. (2004) The science behind soyfoods. In: Proceedings of I IV World Soybean Researcg Conference, IV Intl. soybean processing and utilization conference and III Brazilian soybean congress. P. 977

Mistry, C.D., Singh, S. and Sharma, R.S. (1992). Physico-chemical characteristics of Paneer from cow milk by altering salt balance. Australian Journal of Dairy Technology 47:23-27.

Mohammad, K.S. and Fox, P.F.(1987) Heat induced microstructural changes in casein micelles before and after heat coagulation. New Zealand Journal of Dairy Science and Technology 22:191203.

Modler, H.W. and Emmons, D.B. (1989) Production and Yield of whole milk Ricotta manufactured by a continuous process. Milchwissenschaft 44:753-757.

Muir, D.D., Williams, S.A.R., Tamime A.Y. and Shenana, M.E. (1997) Comparison of the sensory profiles of regular and reduced fat commercial processed cheese spreads. International Journal of Food Science and Technology. 32, 279-287.

Mulvihill, D.M. and Grufferty, M.B.(1995) Effect of thermal processing on the coagulability of milk by acid, in Heat induced changes in milk, $2^{\text {nd }}$ edition, Special Issue, 9501, International Dairy Federation, Brussels, pp.188-205. 
Muthukumarappan K., Wang Y.C. and Gunasekaran S., (1999) Modified Schreiber test for evaluation of Mozzarella cheese flowability. Journal of Dairy Science 82:1068.

Nilson, K.M. and Streiff, P. (1978). Comparison of whey Ricotta cheese manufactured from whey and wehy concentrates. Proceedings from $15^{\text {th }}$ Marschall Invitation Cheese Seminar, Madison, WI pp.1-12.

Noh, B.S., and Richardson, T., (1989) Incorporation of radiolabelled whey proteins into casein micelles by heat processing. Journal of Dairy Science 72:1724-1731.

Norman, A.G. (1978) Soybean physiology, agronomy and utilization, A.G. Norman (Ed.) Academic Press, New York.

Obatulu V.(2008). Effect of different coagulants on yield and quality of tofu from soymilk.

European Food Research Tecnology 226:467.

Oldfield, D.J., Singh, H., Taylor, M.W. (1998). Association of $\beta$-lactoglobulin and $\alpha$-lactalbumin with casein micelees in skim milk heated in an ultra-high temperature plant. International Dairy Journal 8:765-770.

Olkku, J. and. Rha C.K, (1975) Textural parameters of candy licorice. Journal of Food Science 40:1050-1054.

Olson N.F. and Price W.V. (1958) A flowing test for pasteurized process cheese spreads. Journal of Dairy Science 41(7):999.

Olson, N.F., Gunasekaran S. and Bogenrief D.D. (1998) Chemical and physical properties of cheese and their interactions. Netherland Milk Dairy Journal 50:279-294.

Pant A., Chauhan G.S. and Verma N.S. (1993) Texture Profile Analysis of Tofu and Milk Paneer Before and After Deep-Fat-Frying. Journal of food science and Technology, 30(6) :449

Park J., J.R. Rosenau and M. peleg. (1984) Comparison of four procedures of cheese flowability evaluation. Journal of Food Science 49:1158.

Parnell-Clunies, E.M., Irvine, D.M. and Bullock, D.H. (1985) Heat treatment and homogenization of milk for Queso Blanco (Latin American White Cheese) manufacture.

Pyne, G.T. and McGann, T.C.A. (1960). The colloidal calcium phosphate of milk. II. Influence of citrate. Journal of Dairy Research 27:9-17.

Rao, K.V.S.S., Zanjpad, P.N. and Mathur, B.N.(1992). Paneer technology- a review. Indian Journal of Dairy Science. 52:1347-1355.

Robinson, R.K. (1991). Halloumi cheese: the product and its manufacture. In 'Feta and Related Cheeses.' Ellis Horwood Ltd, London. 
Roefs, S.P., Vliet T. and van den Bijgaart H.J.C.M. and Walstra P. (1990) Structure of casein gels made by combined acidification and rennet action. Netherlands Milk Dairy Journal. 44:159-188.

Rowney, M. et al. (1999) Factors affecting functionality of Mozzarella cheese. Australian Journal of Dairy Technology 54:94-102.

Saio, K. (1979) Tofu: Relationship between texture and fine structure. Cereal Foods World 24:342354

Sawyer, W.H.(1969). Complex between $\beta$-lactoglobulin and $\kappa$-casein. A Review. Journal of Dairy Sci. 52:1347-1355.

Schaefer, M.J. and Love J. (1992). Relationships between soybean components and Tofu texture. Journal of Food Quality 15:53.

Schafer, H.W. and Olson, N.F. (1975) Characteristics of Mozzarella cheese made by direct acidification from ultra-high temperature processed milk. Journal of Dairy Science 58:494-501.

Schmidt, D.G. (1982) Association of casein and casein micelle structure, Developments in Dairy Chemistry-1 Proteins. (P.F.Fox) Applied Science Publishers, London, p. 61-86.

Science. 40:1050.

Schulz, M.E. (1976) Preparation of flow-resistant process cheese. German Patent 3.962,483

Scott-Blair, G. 1958. Rheology in food research. Advances in food research 8:1-56.

Shafer, H.W. and Olson, N.F. (1975) Characteristics of Mozzarella cheese made by direct acidification from ultra-high temperature processed milk. Journal of Dairy Science, 58:494-501.

Shahani, K.M. (1979). Newer technique for making and utilization of Ricotta cheese. $1^{\text {st }}$ Biennial Marschall International Cheese Conference, Madison, WI. pp. 77-87.

Siapantas, L.A., and Kosikowski, F.V. (1965). Acetic acid preparation phenomenon of while milk for Queso Blanco cheese. Journal of Dairy Science 48:764.

Singh, H. and Fox, P.F. (1985). The heat stability of milk: $\mathrm{pH}$ dependent dissociation of micellar $\kappa-$ casein on heating milk at ultra-high temperatures. Journal of Dairy Research 52:529-538.

Skurray G., Cunich J. and Carter O. (1980) The effect of different varieties of soybean and calcium ion concentration on the quality of tofu. Food Chemistry 6:89-95.

Sood, V.K. and Kosikowski F.V. (1979) Process Cheddar cheese from plain and enzyme treated retentates. Journal of Dairy Science 62:1713-8.

Soyatech Inc. and SPINS. (2008) Soyfoods: The U.S. Market 2008. 
Strandholm, J.J., Prochnow, R.R. and Miller, M.S. (1989). Method for controlling flowing properties of process cheese. U.S. patent 4,885,183.

Szczesniak, A.S. (1963) Classification of textural characteristics. Journal of food science 28.385-389.

Szezesniak A.S. (1987) Correlating sensory with instrumental texture measurements- an overview of recent developments. Journals of texture studies 18:1

Torres, N. and Chandan, R.C. (1981). Flavor and texture development in Latin American white cheese. Journal of Dairy Science 64:2161:2169.

Torres, N., and R. C. Chandan. (1981) Latin American white cheese-A review. Journal of Dairy Science 64:552.

True, L.C. (1973). Effect of various processing conditions on the yield of whey Ricotta cheese. Proc. $10^{\text {th }}$ Marschall Invitational Cheese Seminar, Madison, WI. pp. 1-11.

Tsai S.J., Lan C.Y., Kao C.S. and Chen C.S. (1981) Studies on the yield and quality characteristics of tofu. Journal of food science 46:1734.

Utsumi S. and Kinsella J.E. (1985) Forces involved in soy protein gelation: Effects of various reagents on the formation, hardness and solubility of heat-induced gels made from $7 \mathrm{~S}, 11 \mathrm{~S}$, and soy isolate. Journal of food science 50:1278-1282.

Vasbinder A.J., Alting A.C. and Kruif K.G. (2003). Quantification of heat-induced casein-whey protein interactions in milk and its relation of gelation kinetics. Colloids and surfaces B: Biointerfaces (31) 115-123.

Vasbinder, A.J., and Kruif, C.G. (2003). Casein-whey protein interactions in heated milk : the influence of pH. International Dairy Journal 13:669-677.

Vijaynanda P., Mittal B.K. and Kulshershta M. (1989) Instrumental texture profile analysis of soybean curds prepared by acid and salt coagulants. Journal of food science and technology 26:223

Voisey, P.W. and Crete R.A. (1973) A technique for establishing instrumental conditions for measuring food firmness to simulate consumer evaluations. Journal of texture studies. 4:371.

Walstra, P (1990) On the stability of casein micelles. Journal of Dairy Science. 73:1965-79

Wang H.H. and Sun D.W. (2001) Evaluation of the functional properties of Cheddar cheese using a computer vision method. Journal of Food Engineering 49:49.

Wang, H.L. and Hesseltine C.W. (1982) Coagulation conditions in tofu processing. Process Biochemistry 17(1):7 
Wang, H.L. and Cavins J.F. (1969) Yield and amino acid composition of fractions obtained during tofu production. Cereal Chem. 66: 359.

Warner, J.N. (1976) Principles of dairy processing. John Wiley and Sons, New York, NY.

Weigold, G.W. (1958) Development of a factory method for the manufacture of Queso Del Pias. Milk Production Journal. 49(10):16-17,25

Wolf, W.J. and Cowan, J.C. (1971) Soybeans as a food source. CRC Critical Review. Food Technology. 2:81.

Yeung, C.Y. (1997) Texture, composition and yield of a new high moisture cheese. Thesis (M.S.) California Polytechnic State University, San Luis Obispo, CA.

Yuan S. and Chang S.K.(2007). Texture Profile of Tofu as affected by instron parameters and sample preparation, and correlations of instron hardness and springiness with sensory scores. Journal of Food Science. 72(2):136

Yun, J.J. , Barbano D.M., Kindstedt P.S. and Larose K.L. (1995) Mozzarella cheese: impact of whey $\mathrm{pH}$ at draining on chemical, composition, proteolysis and functional properties. Journal of Dairy Science 78:1-7.

Zittle, C.A., Thompson, M.P., Custer J.H. and Cerbulis J. (1962) א-casein- $\beta$-lactoglobulin interaction in solution when heated. Journal of Dairy Science 45:807-810. 


\subsection{APPENDICES}

\section{Experimental Design I Statistical Analysis:}

\subsection{General Linear model for mean fat, mean protein and mean moisture}

\section{General Linear Model: mean fat versus homo, past, acid}

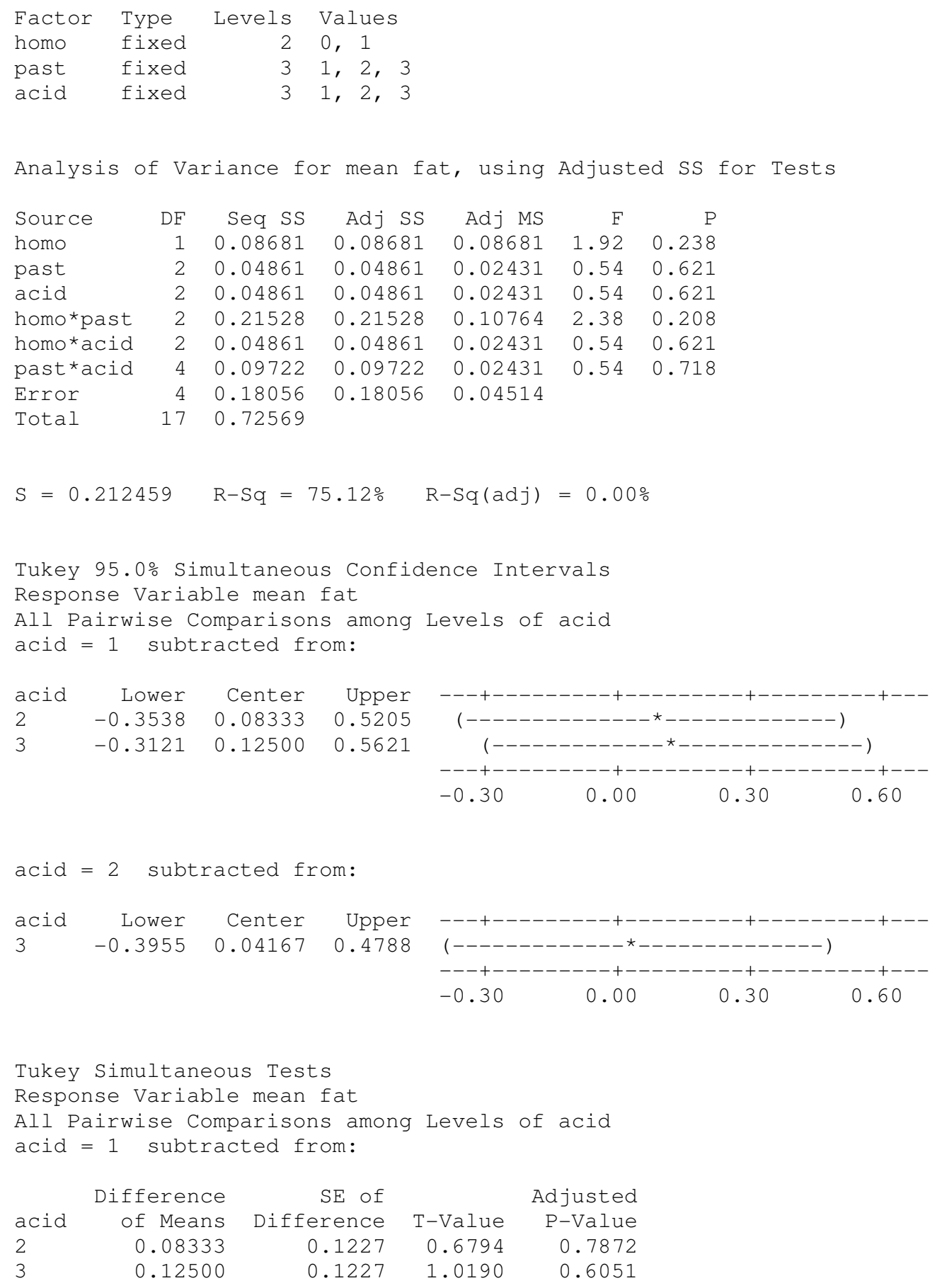

Tukey Simultaneous Tests

Response Variable mean fat

All Pairwise Comparisons among Levels of acid acid $=1$ subtracted from:

$\begin{array}{lrrrr} & \text { Difference } & \text { SE of } & & \text { Adjusted } \\ \text { acid } & \text { of Means } & \text { Difference } & \text { T-Value } & \text { P-Value } \\ 2 & 0.08333 & 0.1227 & 0.6794 & 0.7872 \\ 3 & 0.12500 & 0.1227 & 1.0190 & 0.6051\end{array}$



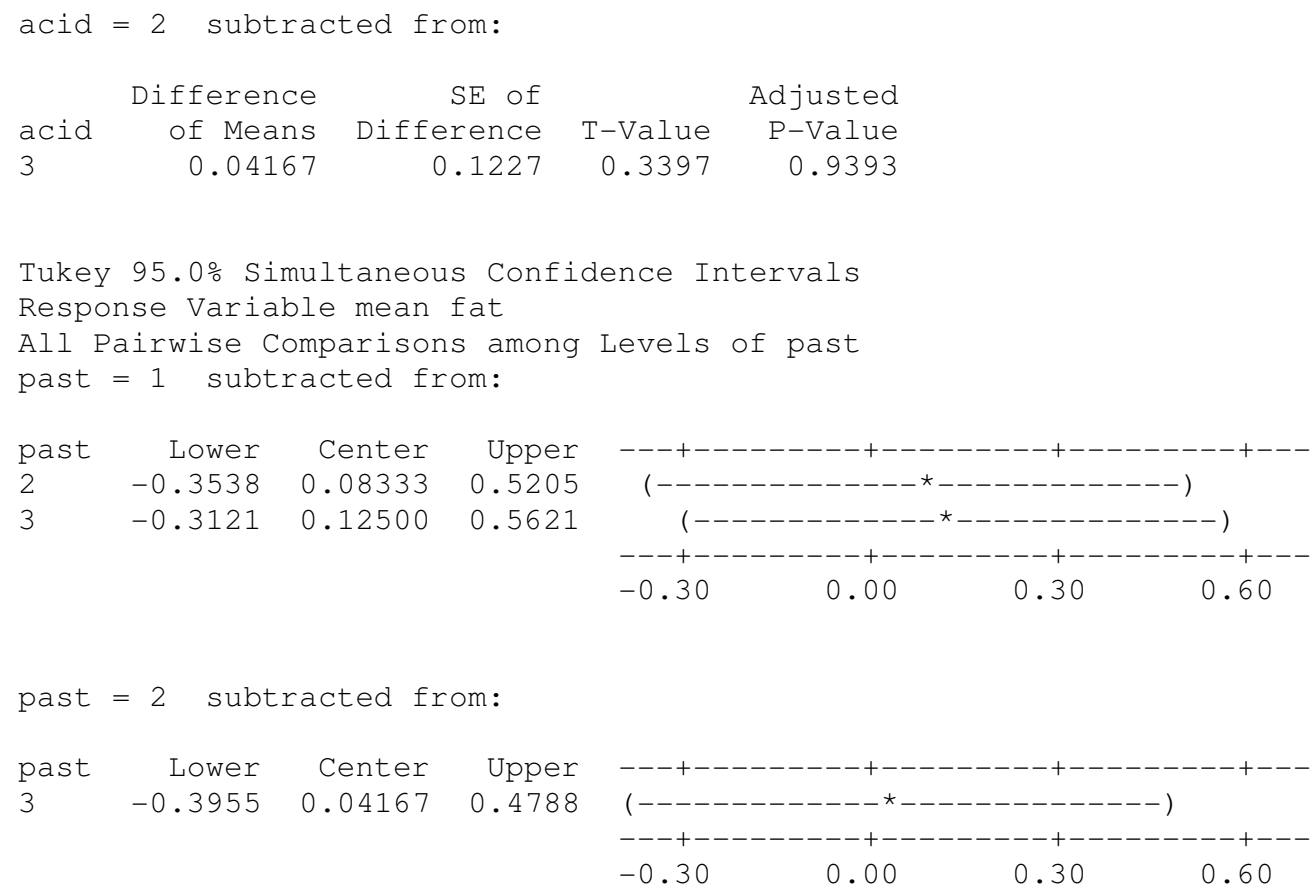

Tukey Simultaneous Tests Response Variable mean fat All Pairwise Comparisons among Levels of past past $=1$ subtracted from:

$\begin{array}{lrrrr} & \text { Difference } & \text { SE of } & & \text { Adjusted } \\ \text { past } & \text { of Means } & \text { Difference } & \text { T-Value } & \text { P-Value } \\ 2 & 0.08333 & 0.1227 & 0.6794 & 0.7872 \\ 3 & 0.12500 & 0.1227 & 1.0190 & 0.6051\end{array}$

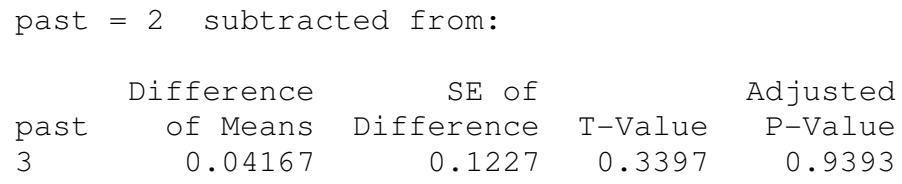

Tukey 95.0\% Simultaneous Confidence Intervals Response Variable mean fat

All Pairwise Comparisons among Levels of homo homo $=0$ subtracted from:

\begin{tabular}{|c|c|c|c|c|}
\hline $\begin{array}{l}\text { homo } \\
1\end{array}$ & $\begin{array}{r}\text { Lower } \\
-0.4170\end{array}$ & $\begin{array}{r}\text { Center } \\
-0.1389\end{array}$ & $\begin{array}{r}\text { Upper } \\
0.1392\end{array}$ & $\begin{array}{c}------+----------+----------+---------+ \\
(----------------\star \\
(-----------------\end{array}$ \\
\hline & & & & $\begin{array}{ccc}---1--+-1 & -1 \\
-0.32 & -0.16 & 0.00\end{array}$ \\
\hline
\end{tabular}

Tukey Simultaneous Tests Response Variable mean fat All Pairwise Comparisons among Levels of homo homo $=0$ subtracted from: 


$\begin{array}{ccccc} & \text { Difference } & \text { SE of } & & \text { Adjusted } \\ \text { homo } & \text { of Means } & \text { Difference } & \text { T-Value } & \text { P-Value } \\ 1 & -0.1389 & 0.1002 & -1.387 & 0.2378 \\ \text { General Linear Model: mean protein versus homo, past, acid }\end{array}$

$\begin{array}{llrl}\text { Factor } & \text { Type } & \text { Levels } & \text { Values } \\ \text { homo } & \text { fixed } & 2 & 0,1 \\ \text { past } & \text { fixed } & 3 & 1,2,3 \\ \text { acid } & \text { fixed } & 3 & 1,2,3\end{array}$

Analysis of Variance for mean protein, using Adjusted SS for Tests

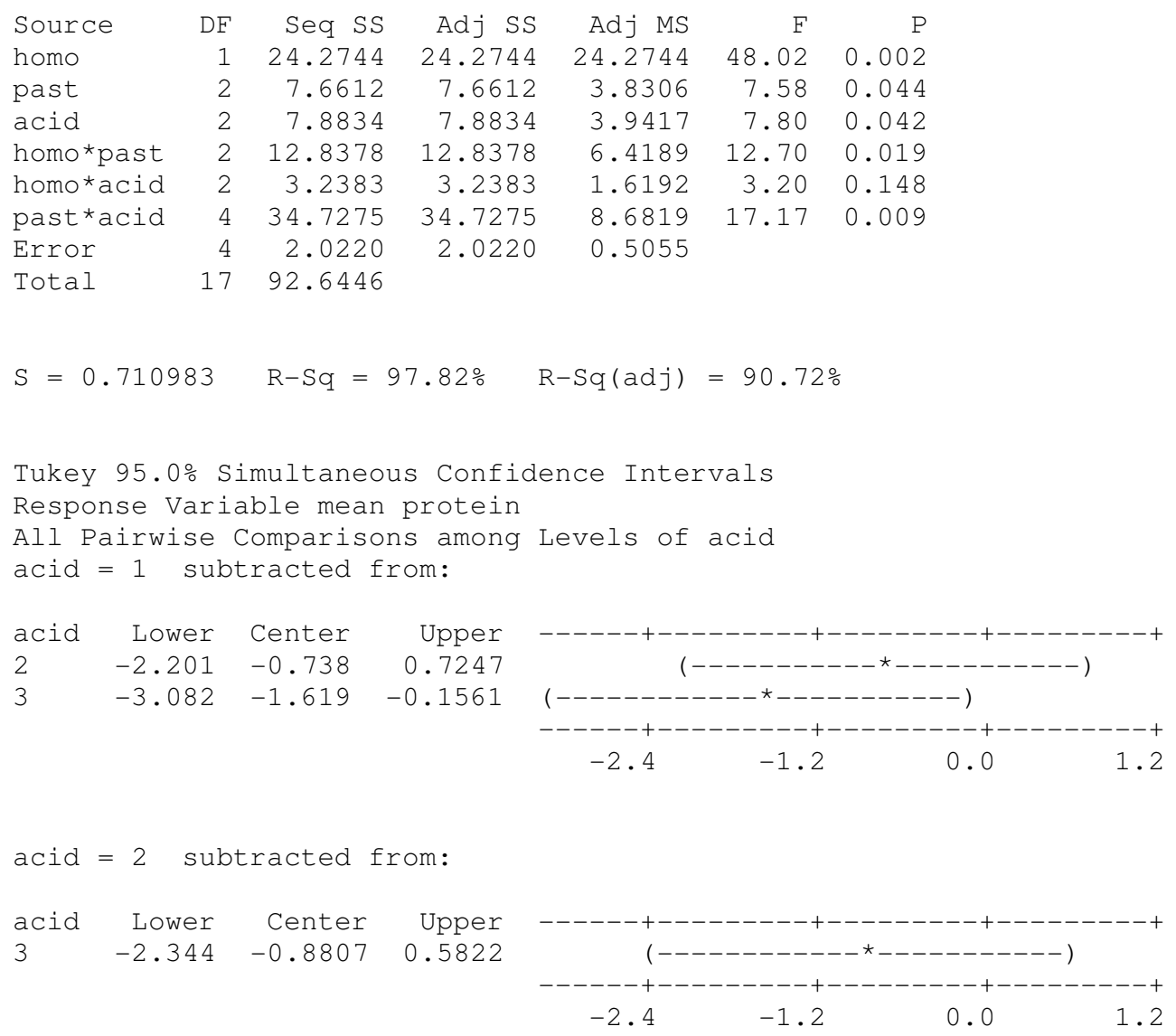

Tukey Simultaneous Tests

Response Variable mean protein

All Pairwise Comparisons among Levels of acid acid $=1$ subtracted from:

\begin{tabular}{|c|c|c|c|c|}
\hline & Difference & $S E$ of & & Adjuste \\
\hline $\operatorname{aci}$ & of Means & Difference & T-Value & $\mathrm{P}-\mathrm{Val}$ \\
\hline 0 & -0.738 & 0.4105 & -1.798 & 0.2 \\
\hline & -1.619 & 0.4105 & -3.944 & 0.0 \\
\hline
\end{tabular}

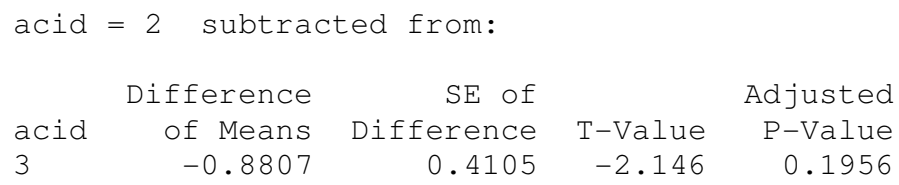


Tukey 95.0\% Simultaneous Confidence Intervals Response Variable mean protein

All Pairwise Comparisons among Levels of past past $=1$ subtracted from:

$\begin{array}{lrrr}\text { past } & \text { Lower } & \text { Center } & \text { Upper } \\ 2 & -0.044 & 1.41896 & 2.882 \\ 3 & -1.390 & 0.07291 & 1.536\end{array}$

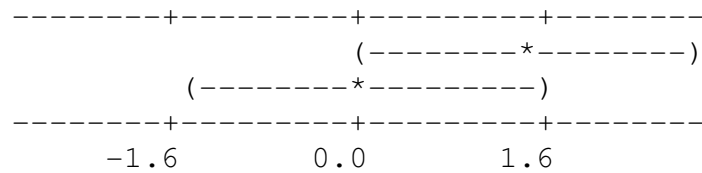

past $=2$ subtracted from:

\begin{tabular}{|c|c|c|c|}
\hline $\begin{array}{lr}\text { past } & \text { Lower } \\
3 & -2.809\end{array}$ & $\begin{array}{l}\text { Center } \\
-1.346\end{array}$ & $\begin{array}{r}\text { Upper } \\
0.1168\end{array}$ & $\begin{array}{l}--------+---------+---------+-------- \\
(---------\star--------)\end{array}$ \\
\hline & & & $\begin{array}{lr}---+------- & -+ \\
-1.6 & 0.0\end{array}$ \\
\hline
\end{tabular}

Tukey Simultaneous Tests

Response Variable mean protein

All Pairwise Comparisons among Levels of past past $=1$ subtracted from:

$\begin{array}{lrrrr} & \text { Difference } & \text { SE of } & \text { Adjusted } \\ \text { past } & \text { of Means } & \text { Difference } & \text { T-Value } & \text { P-Value } \\ 2 & 1.41896 & 0.4105 & 3.4568 & 0.0549 \\ 3 & 0.07291 & 0.4105 & 0.1776 & 0.9828\end{array}$

$\begin{array}{lrrrr}\text { past }=2 & \text { subtracted from: } & \\ & & & \\ \text { pifference } & \text { SE of } & & \text { Adjusted } \\ 3 & \text { of Means } & \text { Difference } & \text { T-Value } & \text { P-Value } \\ 3 & -1.346 & 0.4105 & -3.279 & 0.0644\end{array}$

Tukey 95.0\% Simultaneous Confidence Intervals Response Variable mean protein

All Pairwise Comparisons among Levels of homo homo $=0$ subtracted from:

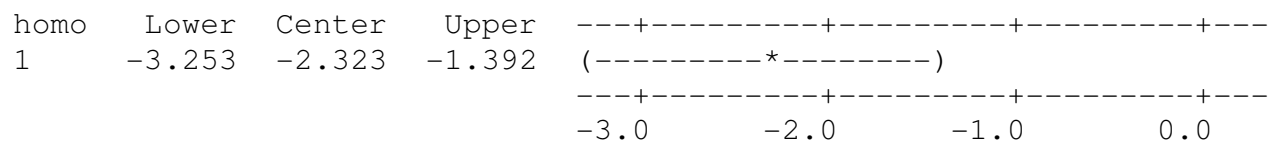

Tukey Simultaneous Tests Response Variable mean protein

All Pairwise Comparisons among Levels of homo homo $=0$ subtracted from:

$\begin{array}{rrrrr} & \text { Difference } & \text { SE of } & \text { Adjusted } \\ \text { homo } & \text { of Means } & \text { Difference } & \text { T-Value } & \text { P-Value } \\ 1 & -2.323 & 0.3352 & -6.930 & 0.0023\end{array}$




\section{General Linear Model: mean moisture versus homo, past, acid}

$\begin{array}{llrl}\text { Factor } & \text { Type } & \text { Levels } & \text { Values } \\ \text { homo } & \text { fixed } & 2 & 0,1 \\ \text { past } & \text { fixed } & 3 & 1,2,3 \\ \text { acid } & \text { fixed } & 3 & 1,2,3\end{array}$

Analysis of Variance for mean moisture, using Adjusted ss for Tests

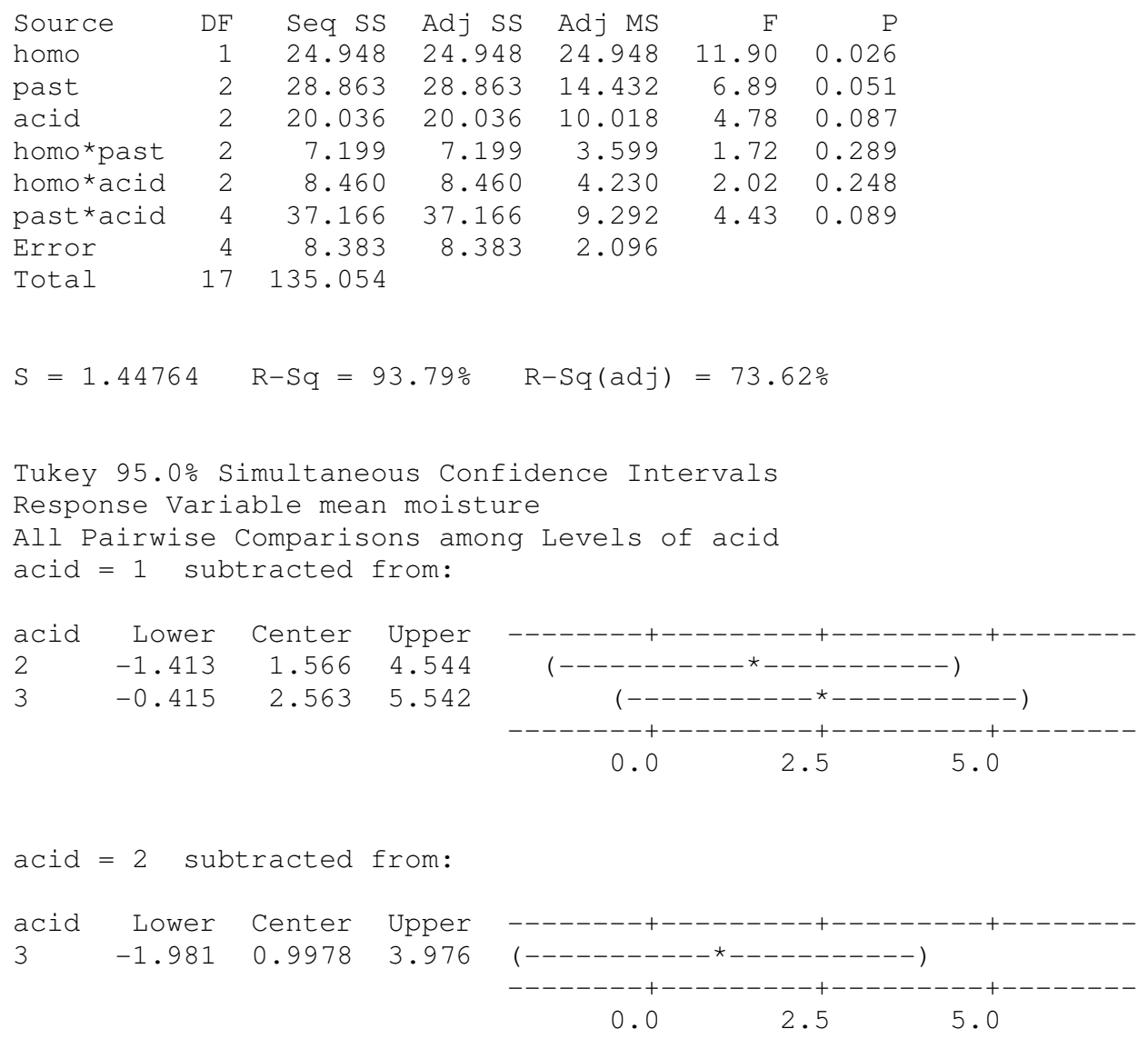

Tukey Simultaneous Tests

Response Variable mean moisture

All Pairwise Comparisons among Levels of acid acid $=1$ subtracted from:

$\begin{array}{lrrrr} & \text { Difference } & \text { SE of } & & \text { Adjusted } \\ \text { acid } & \text { of Means } & \text { Difference } & \text { T-Value } & \text { P-Value } \\ 2 & 1.566 & 0.8358 & 1.873 & 0.2598 \\ 3 & 2.563 & 0.8358 & 3.067 & 0.0783\end{array}$

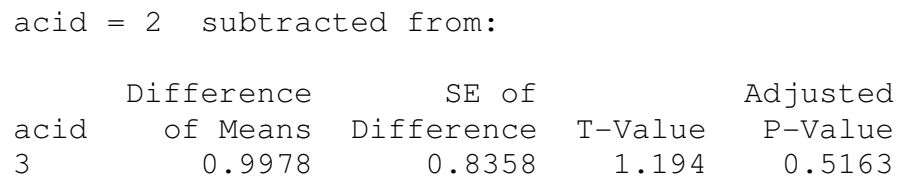


Response Variable mean moisture

All Pairwise Comparisons among Levels of past

past $=1$ subtracted from:

$\begin{array}{lrrr}\text { past } & \text { Lower } & \text { Center } & \text { Upper } \\ 2 & -3.522 & -0.5432 & 2.435 \\ 3 & -0.606 & 2.3731 & 5.352\end{array}$

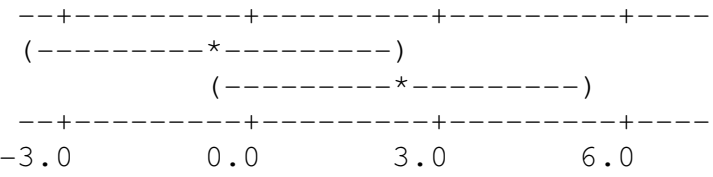

past $=2$ subtracted from:

past Lower Center Upper

$\begin{array}{llll}3 & -0.06231 & 2.916 & 5.895\end{array}$

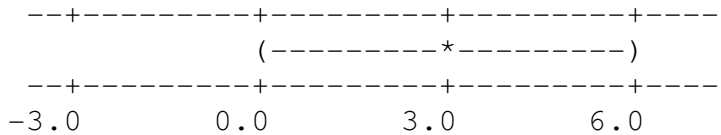

Tukey Simultaneous Tests

Response Variable mean moisture

All Pairwise Comparisons among Levels of past

past $=1$ subtracted from:

$\begin{array}{lrrrr} & \text { Difference } & \text { SE of } & \text { Adjusted } \\ \text { past } & \text { of Means } & \text { Difference } & \text { T-Value } & \text { P-Value } \\ 2 & -0.5432 & 0.8358 & -0.6499 & 0.8025 \\ 3 & 2.3731 & 0.8358 & 2.8393 & 0.0973\end{array}$

$\begin{array}{lrrrr}\text { past }=2 & \text { subtracted from: } & \\ & & & \\ \text { pifference } & \text { SE of } & & \text { Adjusted } \\ 3 & \text { of Means } & \text { Difference } & \text { T-Value } & \text { P-Value } \\ \text { past } & 2.916 & 0.8358 & 3.489 & 0.0534\end{array}$

Tukey 95.0\% Simultaneous Confidence Intervals Response Variable mean moisture

All Pairwise Comparisons among Levels of homo homo $=0$ subtracted from:

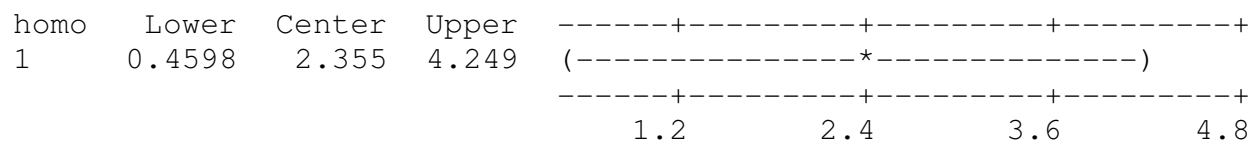

Tukey Simultaneous Tests

Response Variable mean moisture

All Pairwise Comparisons among Levels of homo

homo $=0$ subtracted from:

$\begin{array}{lrrrr} & \text { Difference } & \text { SE of } & & \text { Adjusted } \\ \text { homo } & \text { of Means } & \text { Difference } & \text { T-Value } & \text { P-Value } \\ 1 & 2.355 & 0.6824 & 3.450 & 0.0261\end{array}$




\subsection{General Linear Model for mean flow in oven, microwave and boiling water}

$\begin{array}{llrl}\text { Factor } & \text { Type } & \text { Levels } & \text { Values } \\ \text { acid } & \text { fixed } & 3 & 1,2,3 \\ \text { past } & \text { fixed } & 3 & 1,2,3 \\ \text { homo } & \text { fixed } & 2 & 0,1\end{array}$

Analysis of Variance for mean flowing oven, using Adjusted SS for Tests

$\begin{array}{lrrrrrr}\text { Source } & \text { DF } & \text { Seq SS } & \text { Adj SS } & \text { Adj MS } & F & P \\ \text { acid } & 2 & 9.924 & 9.924 & 4.962 & 2.18 & 0.229 \\ \text { past } & 2 & 51.049 & 51.049 & 25.524 & 11.22 & 0.023 \\ \text { homo } & 1 & 2.920 & 2.920 & 2.920 & 1.28 & 0.320 \\ \text { acid*past } & 4 & 14.097 & 14.097 & 3.524 & 1.55 & 0.341 \\ \text { acid*homo } & 2 & 3.965 & 3.965 & 1.983 & 0.87 & 0.485 \\ \text { past*homo } & 2 & 4.174 & 4.174 & 2.087 & 0.92 & 0.470 \\ \text { Error } & 4 & 9.097 & 9.097 & 2.274 & & \\ \text { Total } & 17 & 95.226 & & & & \\ & & & & & & \end{array}$

Analysis of Variance for mean flowing microwave, using Adjusted sS for Tests

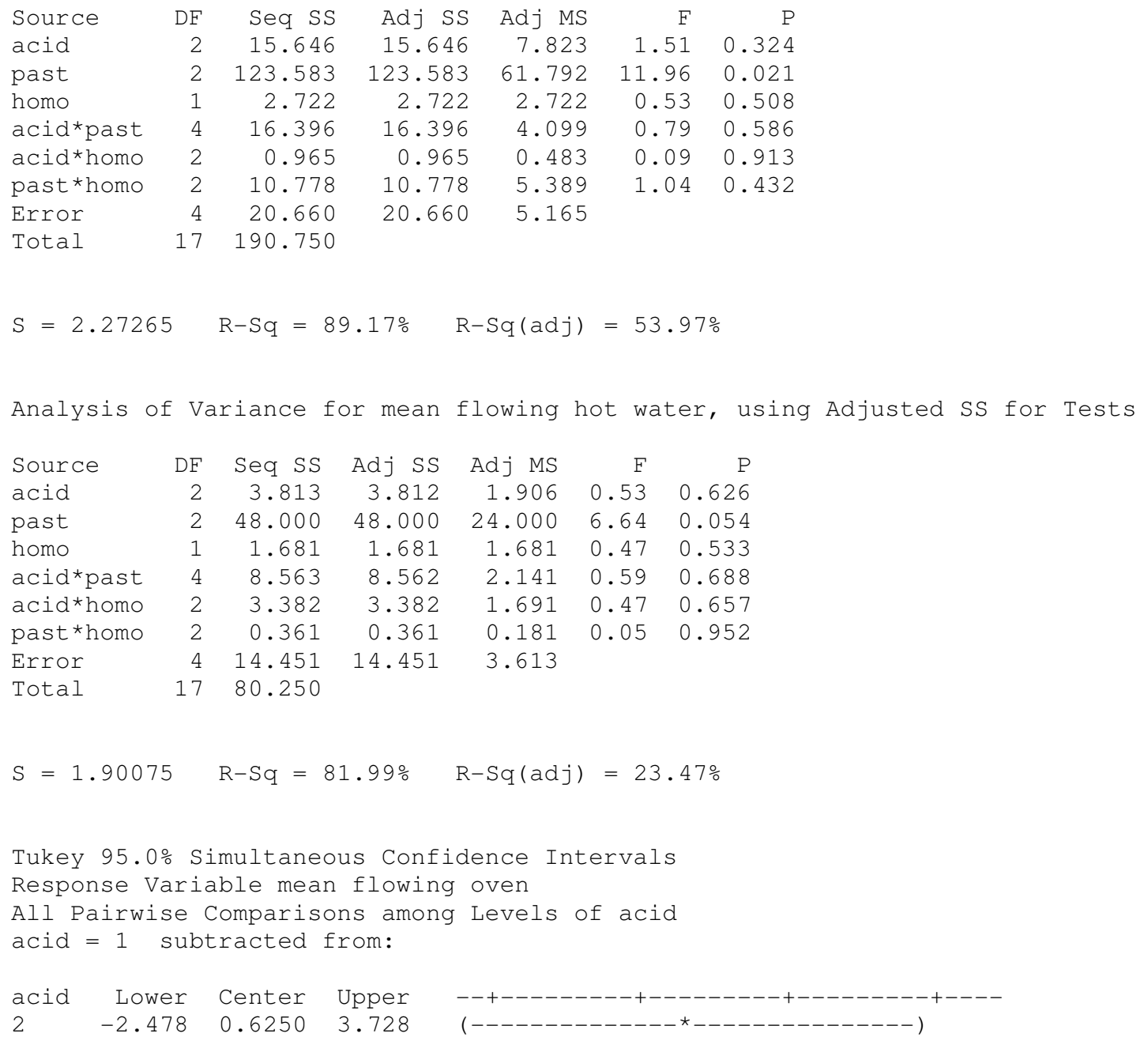




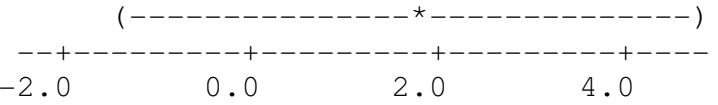

acid $=2$ subtracted from:

acid Lower Center Upper

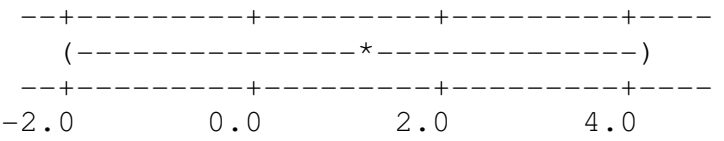

Tukey Simultaneous Tests

Response Variable mean flowing oven

All Pairwise Comparisons among Levels of acid

acid $=1$ subtracted from:

$\begin{array}{lrrrr} & \text { Difference } & \text { SE of } & & \text { Adjusted } \\ \text { acid } & \text { of Means } & \text { Difference } & \text { T-Value } & \text { P-Value } \\ 2 & 0.6250 & 0.8707 & 0.7178 & 0.7670 \\ 3 & 1.7917 & 0.8707 & 2.0578 & 0.2143\end{array}$

acid $=2$ subtracted from:

$\begin{array}{lrrrr} & \text { Difference } & \text { SE of } & & \text { Adjusted } \\ \text { acid } & \text { of Means } & \text { Difference } & \text { T-Value } & \text { P-Value } \\ 3 & 1.167 & 0.8707 & 1.340 & 0.4486\end{array}$

Tukey 95.0\% Simultaneous Confidence Intervals

Response Variable mean flowing oven

All Pairwise Comparisons among Levels of past past $=1$ subtracted from:

past Lower Center Upper

$2 \quad-5.186 \quad-2.083 \quad 1.020$

$\begin{array}{llll}3 & -7.228 & -4.125 & -1.022\end{array}$
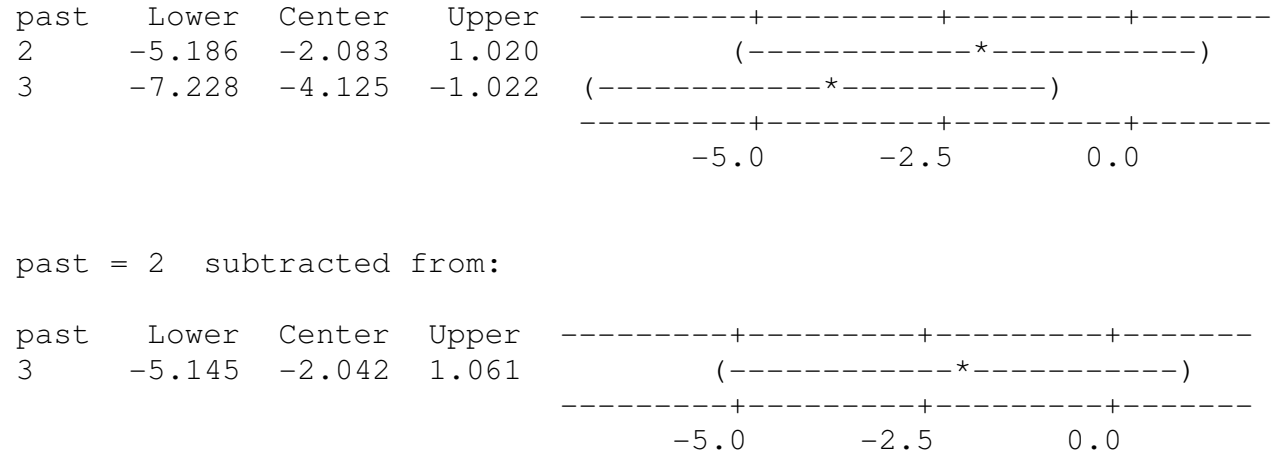

Tukey Simultaneous Tests Response Variable mean flowing oven

All Pairwise Comparisons among Levels of past past $=1$ subtracted from:

$\begin{array}{lrrrr} & \text { Difference } & \text { SE of } & & \text { Adjusted } \\ \text { past } & \text { of Means } & \text { Difference } & \text { T-Value } & \text { P-Value } \\ 2 & -2.083 & 0.8707 & -2.393 & 0.1517 \\ 3 & -4.125 & 0.8707 & -4.738 & 0.0197\end{array}$

past $=2$ subtracted from: 


$\begin{array}{rrrrr} & \text { Difference } & \text { SE of } & \text { Adjusted } \\ \text { past } & \text { of Means } & \text { Difference } & \text { T-Value } & \text { P-Value } \\ 3 & -2.042 & 0.8707 & -2.345 & 0.1593\end{array}$

Tukey 95.0\% Simultaneous Confidence Intervals Response Variable mean flowing oven

All Pairwise Comparisons among Levels of homo homo $=0$ subtracted from:

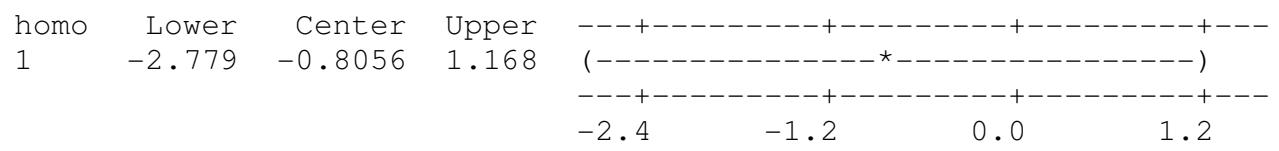

Tukey Simultaneous Tests

Response Variable mean flowing oven

All Pairwise Comparisons among Levels of homo

homo $=0$ subtracted from:

$\begin{array}{rrrrr} & \text { Difference } & \text { SE of } & & \text { Adjusted } \\ \text { homo } & \text { of Means } & \text { Difference } & \text { T-Value } & \text { P-Value } \\ 1 & -0.8056 & 0.7109 & -1.133 & 0.3205\end{array}$

Tukey 95.0\% Simultaneous Confidence Intervals

Response Variable mean flowing microwave

All Pairwise Comparisons among Levels of acid acid $=1$ subtracted from:

\begin{tabular}{|c|c|c|c|c|}
\hline acid & Lower & Center & Upper & $\begin{array}{c}-----+---------+----------++----------+-- \\
\star\end{array}$ \\
\hline 2 & -4.218 & 0.4583 & 5.134 & $(----------------\star---------------)$ \\
\hline & -2.509 & 2.1667 & 6.843 & $\left(\begin{array}{l}(--------------* \\
---------+----------+----------\end{array}\right.$ \\
\hline & & & & 3.0 \\
\hline
\end{tabular}

acid $=2$ subtracted from:

acid Lower Center Upper

$\begin{array}{llll}3 & -2.968 & 1.708 & 6.384\end{array}$

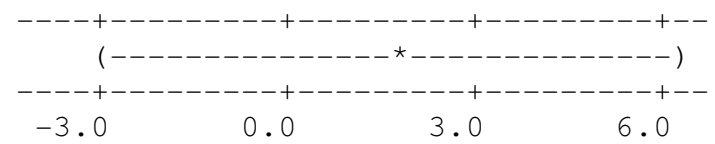

Tukey Simultaneous Tests Response Variable mean flowing microwave All Pairwise Comparisons among Levels of acid acid $=1$ subtracted from:

$\begin{array}{rrrrr} & \text { Difference } & \text { SE of } & \text { Adjusted } \\ \text { acid } & \text { of Means } & \text { Difference } & \text { T-Value } & \text { P-Value } \\ 2 & 0.4583 & 1.312 & 0.3493 & 0.9360 \\ 3 & 2.1667 & 1.312 & 1.6513 & 0.3273\end{array}$

acid $=2$ subtracted from:

$\begin{array}{rrrrr} & \text { Difference } & \text { SE of } & & \text { Adjusted } \\ \text { acid } & \text { of Means } & \text { Difference } & \text { T-Value } & \text { P-Value } \\ 3 & 1.708 & 1.312 & 1.302 & 0.4655\end{array}$


Tukey 95.0\% Simultaneous Confidence Intervals Response Variable mean flowing microwave

All Pairwise Comparisons among Levels of past past $=1$ subtracted from:

$\begin{array}{lrrr}\text { past } & \text { Lower } & \text { Center } & \text { Upper } \\ 2 & -8.01 & -3.333 & 1.343 \\ 3 & -11.09 & -6.417 & -1.741\end{array}$

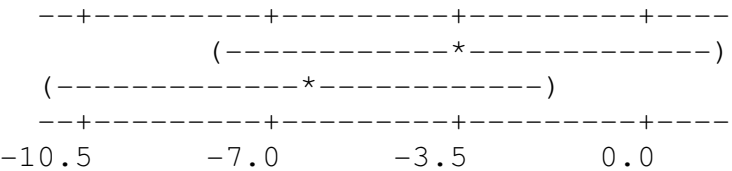

past $=2$ subtracted from:

past Lower Center Upper

$\begin{array}{llll}3 & -7.759 & -3.083 & 1.593\end{array}$

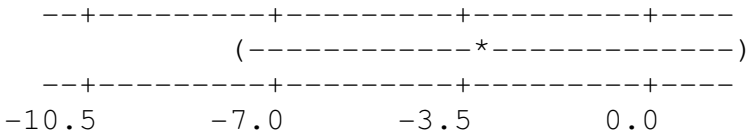

Tukey Simultaneous Tests

Response Variable mean flowing microwave

All Pairwise Comparisons among Levels of past past $=1$ subtracted from:

\begin{tabular}{|c|c|c|c|c|}
\hline & Difference & $\mathrm{SE}$ of & & Adjusted \\
\hline past & of Means & Difference & T-Value & P-Value \\
\hline 2 & -3.333 & 1.312 & -2.540 & 0.1307 \\
\hline 3 & -6.41 & 1.312 & -4.890 & 0.0176 \\
\hline bast & subt & ced from: & & \\
\hline & Difference & SE of & & Adjus \\
\hline past & of Means & Difference & T-Value & P-Value \\
\hline & -3.083 & 1.312 & -2.350 & 0.15 \\
\hline
\end{tabular}

Tukey 95.0\% Simultaneous Confidence Intervals Response Variable mean flowing microwave All Pairwise Comparisons among Levels of homo homo $=0$ subtracted from:

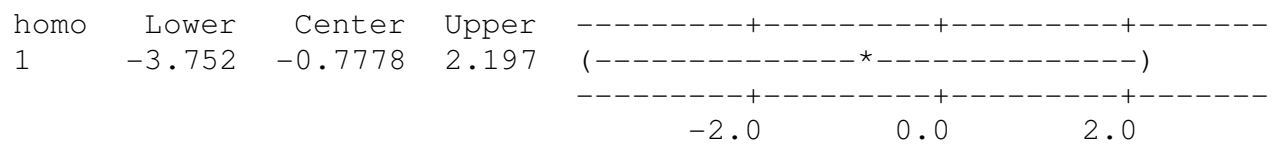

Tukey Simultaneous Tests

Response Variable mean flowing microwave

All Pairwise Comparisons among Levels of homo homo $=0$ subtracted from:

$\begin{array}{lrrrr} & \text { Difference } & \text { SE of } & \text { Adjusted } \\ \text { homo } & \text { of Means } & \text { Difference } & \text { T-Value } & \text { P-Value } \\ 1 & -0.7778 & 1.071 & -0.7260 & 0.5081\end{array}$


Tukey 95.0\% Simultaneous Confidence Intervals

Response Variable mean flowing hot water

All Pairwise Comparisons among Levels of acid

acid $=1$ subtracted from:

\begin{tabular}{|c|c|c|c|c|}
\hline acid & Lower & Center & Upper & $\begin{array}{l}----++----------+-----------+----------+-- \\
(----------------\star----------------)\end{array}$ \\
\hline 3 & -2.786 & 1.1250 & 5.036 & $(----------------\star---------------)$ \\
\hline & & & & -2.5 \\
\hline
\end{tabular}

acid $=2$ subtracted from:

acid Lower Center Upper ----+---------+---------+---------+--

$3-3.2860 .6250 \quad 4.536 \quad(---------------\star--------------)$

\begin{tabular}{|c|c|}
\hline-2.5 & 0.0 \\
\hline
\end{tabular}

Tukey Simultaneous Tests

Response Variable mean flowing hot water

All Pairwise Comparisons among Levels of acid acid $=1$ subtracted from:

$\begin{array}{rrrrr} & \text { Difference } & \text { SE of } & \text { Adjusted } \\ \text { acid } & \text { of Means } & \text { Difference } & \text { T-Value } & \text { P-Value } \\ 2 & 0.5000 & 1.097 & 0.4556 & 0.8947 \\ 3 & 1.1250 & 1.097 & 1.0252 & 0.6019\end{array}$

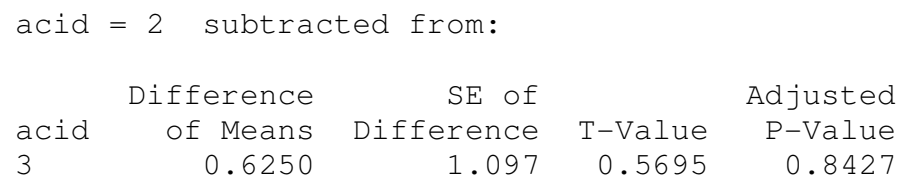

Tukey 95.0\% Simultaneous Confidence Intervals Response Variable mean flowing hot water All Pairwise Comparisons among Levels of past past $=1$ subtracted from:

\begin{tabular}{|c|c|c|c|c|}
\hline $\begin{array}{l}\text { past } \\
2\end{array}$ & $\begin{array}{r}\text { Lower } \\
-5.911\end{array}$ & $\begin{array}{l}\text { Center } \\
-2.000\end{array}$ & $\begin{array}{r}\text { Upper } \\
1.91093\end{array}$ & $\begin{array}{c}------+---------+---------++---------+ \\
(------------\star------------)\end{array}$ \\
\hline 3 & -7.911 & -4.000 & -0.08907 & $(-------------\star \star-------------)$ \\
\hline & & & & $\begin{array}{ccc}------+-------1+---- & ---+-----1 \\
-6.0 & -3.0 & 0.0\end{array}$ \\
\hline
\end{tabular}

past $=2$ subtracted from:

past Lower Center Upper ------+---------+---------+---------+

$3-5.911-2.0001 .91120$

\begin{tabular}{|c|c|c|}
\hline-6 . & -3.0 & 0.0 \\
\hline
\end{tabular}

Tukey Simultaneous Tests

Response Variable mean flowing hot water

All Pairwise Comparisons among Levels of past

past $=1$ subtracted from: 


\begin{tabular}{|c|c|c|c|c|}
\hline \multirow[b]{2}{*}{ past } & Difference & $S E$ of & & Adjusted \\
\hline & of Means & Difference & T-Value & P-Value \\
\hline 2 & -2.000 & 1.097 & -1.822 & 0.2739 \\
\hline 3 & -4.000 & 1.097 & -3.645 & 0.0466 \\
\hline past & $=2$ & Led from: & & \\
\hline & Difference & $S E$ of & & Adjusted \\
\hline past & of Means & Difference & T-Value & P-Value \\
\hline 3 & -2.000 & 1.097 & -1.822 & 0.2739 \\
\hline
\end{tabular}

Tukey 95.0\% Simultaneous Confidence Intervals Response Variable mean flowing hot water

All Pairwise Comparisons among Levels of homo homo $=0$ subtracted from:

homo Lower Center Upper

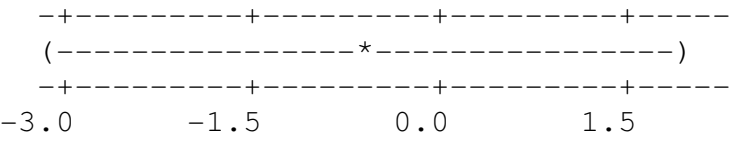

Tukey Simultaneous Tests

Response Variable mean flowing hot water

All Pairwise Comparisons among Levels of homo

homo $=0$ subtracted from:

$\begin{array}{lrrrr} & \text { Difference } & \text { SE of } & \text { Adjusted } \\ \text { homo } & \text { of Means } & \text { Difference } & \text { T-Value } & \text { P-Value } \\ 1 & -0.6111 & 0.8960 & -0.6820 & 0.5327\end{array}$




\subsection{General Linear Model for mean hardnes, mean cohesiveness, mean springiness, mean gumminess and mean chewiness}

$\begin{array}{llrl}\text { Factor } & \text { Type } & \text { Levels } & \text { Values } \\ \text { acid } & \text { fixed } & 3 & 1,2,3 \\ \text { past } & \text { fixed } & 3 & 1,2,3 \\ \text { homo } & \text { fixed } & 2 & 0,1\end{array}$

Analysis of Variance for mean hardness, using Adjusted Ss for Tests

$\begin{array}{lrrrrrr}\text { Source } & \text { DF } & \text { Seq SS } & \text { Adj SS } & \text { Adj MS } & F & P \\ \text { acid } & 2 & 265930 & 265930 & 132965 & 0.71 & 0.544 \\ \text { past } & 2 & 5562532 & 5562532 & 2781266 & 14.89 & 0.014 \\ \text { homo } & 1 & 295224 & 295224 & 295224 & 1.58 & 0.277 \\ \text { acid*past } & 4 & 6198152 & 6198152 & 1549538 & 8.29 & 0.032 \\ \text { acid*homo } & 2 & 112994 & 112994 & 56497 & 0.30 & 0.755 \\ \text { past*homo } & 2 & 2328521 & 2328521 & 1164260 & 6.23 & 0.059 \\ \text { Error } & 4 & 747304 & 747304 & 186826 & & \\ \text { Total } & 17 & 15510656 & & & & \end{array}$

$\mathrm{S}=432.234 \mathrm{R}-\mathrm{Sq}=95.18 \% \mathrm{R}-\mathrm{Sq}(\operatorname{adj})=79.52 \%$

Analysis of Variance for mean cohesiveness, using Adjusted SS for Tests

$\begin{array}{lrrrrrr}\text { Source } & \text { DF } & \text { Seq SS } & \text { Adj SS } & \text { Adj MS } & F & P \\ \text { acid } & 2 & 0.002634 & 0.002634 & 0.001317 & 0.29 & 0.765 \\ \text { past } & 2 & 0.001107 & 0.001107 & 0.000554 & 0.12 & 0.890 \\ \text { homo } & 1 & 0.006168 & 0.006168 & 0.006168 & 1.34 & 0.311 \\ \text { acid*past } & 4 & 0.009844 & 0.009844 & 0.002461 & 0.54 & 0.720 \\ \text { acid*homo } & 2 & 0.016241 & 0.016241 & 0.008121 & 1.77 & 0.282 \\ \text { past*homo } & 2 & 0.005441 & 0.005441 & 0.002720 & 0.59 & 0.595 \\ \text { Error } & 4 & 0.018373 & 0.018373 & 0.004593 & & \end{array}$

Total $17-0.059809$

$S=0.0677728 \quad R-S q=69.28 \% \quad R-S q(\operatorname{adj})=0.00 \%$

Analysis of Variance for mean springiness, using Adjusted sS for Tests

$\begin{array}{lrrrrrr}\text { Source } & \text { DF } & \text { Seq SS } & \text { Adj SS } & \text { Adj MS } & \text { F } & P \\ \text { acid } & 2 & 1.2379 & 1.2379 & 0.6189 & 0.96 & 0.455 \\ \text { past } & 2 & 4.1598 & 4.1598 & 2.0799 & 3.24 & 0.146 \\ \text { homo } & 1 & 0.0220 & 0.0220 & 0.0220 & 0.03 & 0.862 \\ \text { acid*past } & 4 & 1.8313 & 1.8313 & 0.4578 & 0.71 & 0.624 \\ \text { acid*homo } & 2 & 0.4415 & 0.4415 & 0.2208 & 0.34 & 0.728 \\ \text { past*homo } & 2 & 2.7895 & 2.7895 & 1.3947 & 2.17 & 0.230 \\ \text { Error } & 4 & 2.5668 & 2.5668 & 0.6417 & & \\ \text { Total } & 17 & 13.0487 & & & & \end{array}$

$\mathrm{S}=0.801069 \quad \mathrm{R}-\mathrm{Sq}=80.33 \% \mathrm{R}-\mathrm{Sq}(\mathrm{adj})=16.40 \%$

Analysis of Variance for mean gumminess, using Adjusted ss for Tests

$\begin{array}{lrrrrrr}\text { Source } & \text { DF } & \text { Seq SS } & \text { Adj SS } & \text { Adj MS } & F & P \\ \text { acid } & 2 & 45752 & 45752 & 22876 & 0.30 & 0.753 \\ \text { past } & 2 & 1866413 & 1866413 & 933207 & 12.43 & 0.019\end{array}$




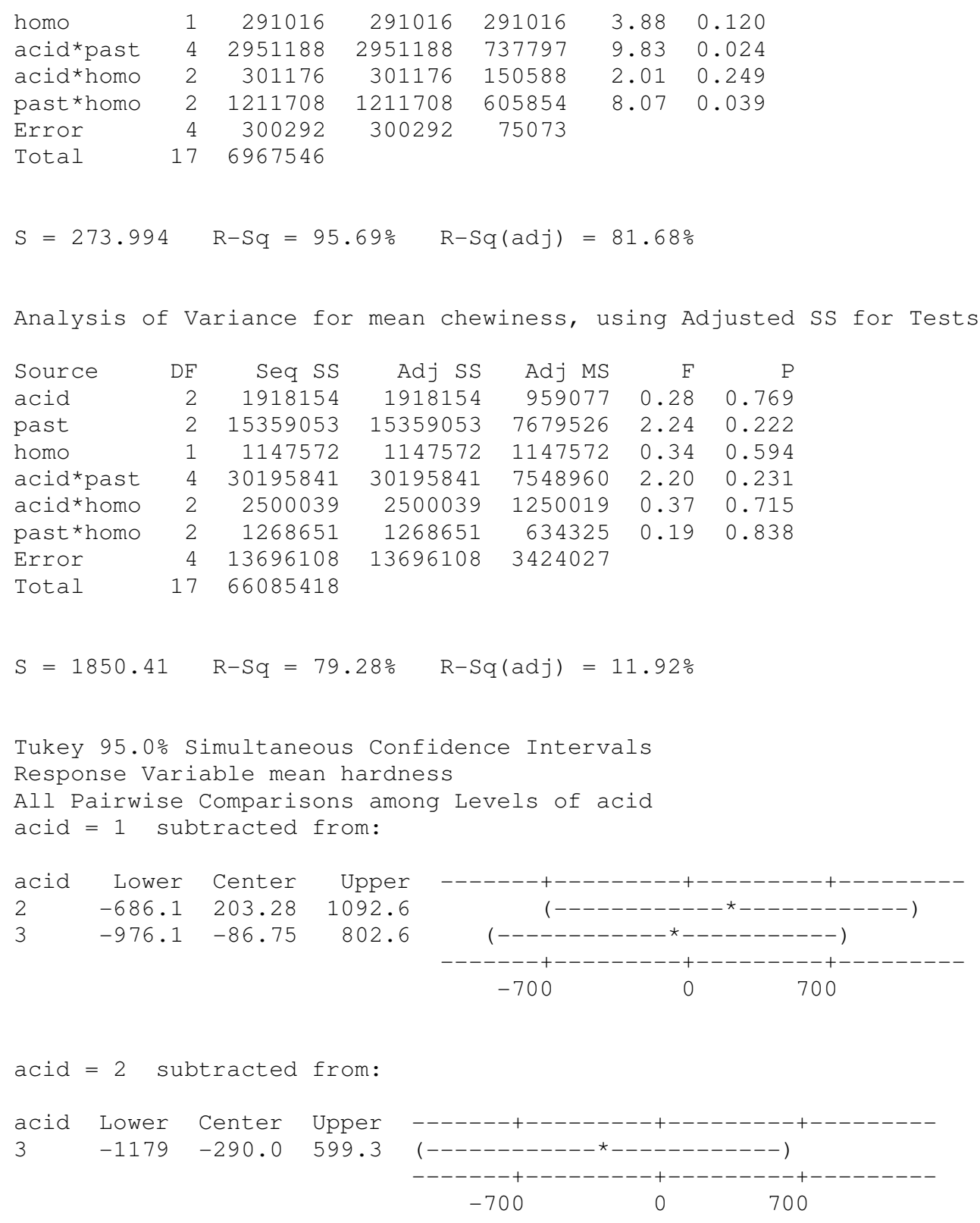

Tukey Simultaneous Tests

Response Variable mean hardness

All Pairwise Comparisons among Levels of acid acid $=1$ subtracted from:

$\begin{array}{lrrrr} & \text { Difference } & \text { SE of } & \text { Adjusted } \\ \text { acid } & \text { of Means } & \text { Difference } & \text { T-Value } & \text { P-Value } \\ 2 & 203.28 & 249.6 & 0.8146 & 0.7150 \\ 3 & -86.75 & 249.6 & -0.3476 & 0.9366\end{array}$

\begin{tabular}{lrrrr} 
acid $=2$ & \multicolumn{2}{c}{ subtracted from: } \\
& Difference & SE of & & Adjusted \\
acid & of Means & Difference & T-Value & P-Value \\
3 & -290.0 & 249.6 & -1.162 & 0.5319
\end{tabular}


Tukey 95.0\% Simultaneous Confidence Intervals Response Variable mean hardness

All Pairwise Comparisons among Levels of past past $=1$ subtracted from:

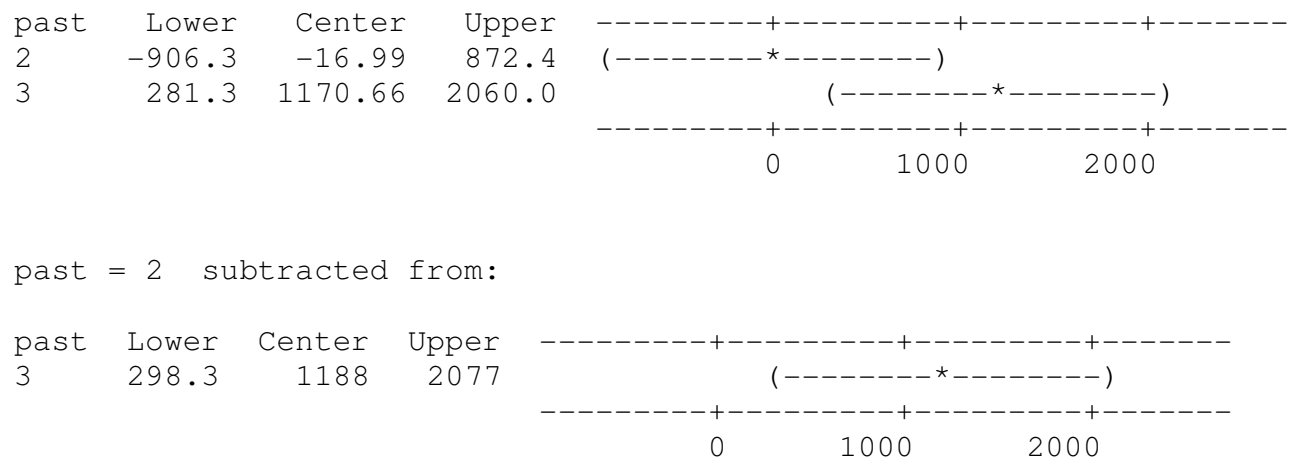

Tukey Simultaneous Tests

Response Variable mean hardness

All Pairwise Comparisons among Levels of past past $=1$ subtracted from:

$\begin{array}{lrrrr} & \text { Difference } & \text { SE of } & \text { Adjusted } \\ \text { past } & \text { of Means } & \text { Difference } & \text { T-Value } & \text { P-Value } \\ 2 & -16.99 & 249.6 & -0.06809 & 0.9974 \\ 3 & 1170.66 & 249.6 & 4.69109 & 0.0204\end{array}$

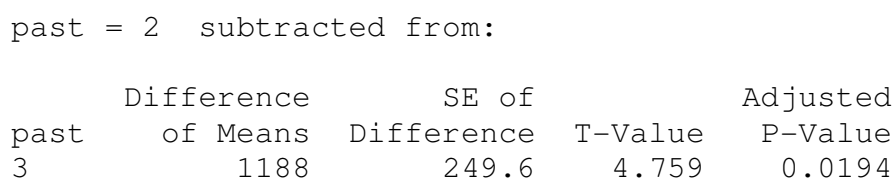

Tukey 95.0\% Simultaneous Confidence Intervals Response Variable mean hardness

All Pairwise Comparisons among Levels of homo homo $=0$ subtracted from:

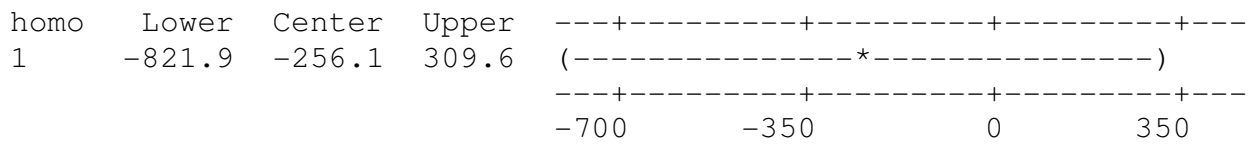

Tukey Simultaneous Tests Response Variable mean hardness

All Pairwise Comparisons among Levels of homo homo $=0$ subtracted from:

$\begin{array}{lrrrr} & \text { Difference } & \text { SE of } & \text { Adjusted } \\ \text { homo } & \text { of Means } & \text { Difference } & \text { T-Value } & \text { P-Value } \\ 1 & -256.1 & 203.8 & -1.257 & 0.2771\end{array}$

Tukey 95.0\% Simultaneous Confidence Intervals

Response Variable mean cohesiveness 
All Pairwise Comparisons among Levels of acid acid $=1$ subtracted from:

\begin{tabular}{|c|c|c|c|c|}
\hline $\begin{array}{l}\text { acid } \\
2\end{array}$ & $\begin{array}{r}\text { Lower } \\
-0.1637\end{array}$ & $\begin{array}{r}\text { Center } \\
-0.02423\end{array}$ & $\begin{array}{r}\text { Upper } \\
0.1152\end{array}$ & $\begin{array}{l}-------+---------+---------+---------+ \\
(-------------\star \\
\text { ( }-------------)\end{array}$ \\
\hline 3 & -0.1368 & 0.00266 & 0.1421 & $\left(--------------{ }^{\star}--------------\right)$ \\
\hline & & & & -0.10 \\
\hline
\end{tabular}

acid $=2$ subtracted from:

acid Lower Center Upper

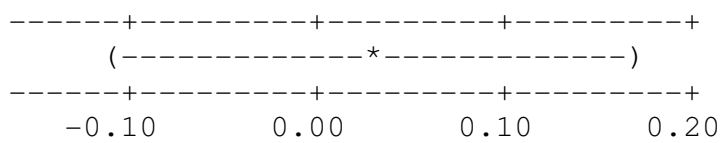

Tukey Simultaneous Tests

Response Variable mean cohesiveness

All Pairwise Comparisons among Levels of acid

acid $=1$ subtracted from:

$\begin{array}{lrrrr} & \text { Difference } & \text { SE of } & \text { Adjusted } \\ \text { acid } & \text { of Means } & \text { Difference } & \text { T-Value } & \text { P-Value } \\ 2 & -0.02423 & 0.03913 & -0.6192 & 0.8181 \\ 3 & 0.00266 & 0.03913 & 0.0679 & 0.9975\end{array}$

acid $=2$ subtracted from:

$\begin{array}{rrrrr} & \text { Difference } & \text { SE of } & \text { Adjusted } \\ \text { acid } & \text { of Means } & \text { Difference } & \text { T-Value } & \text { P-Value } \\ 3 & 0.02689 & 0.03913 & 0.6871 & 0.7832\end{array}$

Tukey 95.0\% Simultaneous Confidence Intervals Response Variable mean cohesiveness

All Pairwise Comparisons among Levels of past past $=1$ subtracted from:

$\begin{array}{lrrr}\text { past } & \text { Lower } & \text { Center } & \text { Upper } \\ 2 & -0.1483 & -0.00886 & 0.1306 \\ 3 & -0.1586 & -0.01919 & 0.1203\end{array}$

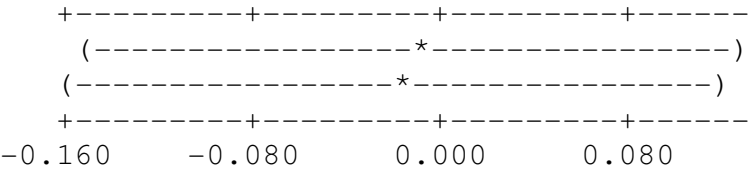

past $=2$ subtracted from:

past Lower Center Upper

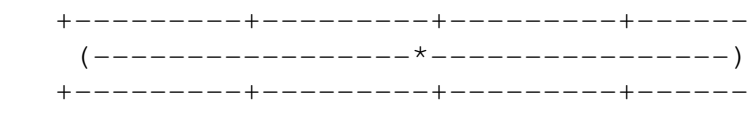

$\begin{array}{llll}-0.160 & -0.080 & 0.000 & 0.080\end{array}$

Tukey Simultaneous Tests

Response Variable mean cohesiveness

All Pairwise Comparisons among Levels of past

past $=1$ subtracted from:

Difference SE of Adjusted

past of Means Difference T-Value P-Value 


$\begin{array}{lrrrr}2 & -0.00886 & 0.03913 & -0.2263 & 0.9724 \\ 3 & -0.01919 & 0.03913 & -0.4905 & 0.8796 \\ & & & \\ \text { past }=2 & \text { subtracted from: } & & \\ & & & & \\ \text { past } & \text { Difference } & \text { SE of } & & \\ 3 & -0.01034 & 0.03913 & -0.2642 & 0.9626\end{array}$

Tukey 95.0\% Simultaneous Confidence Intervals Response Variable mean cohesiveness

All Pairwise Comparisons among Levels of homo homo $=0$ subtracted from:

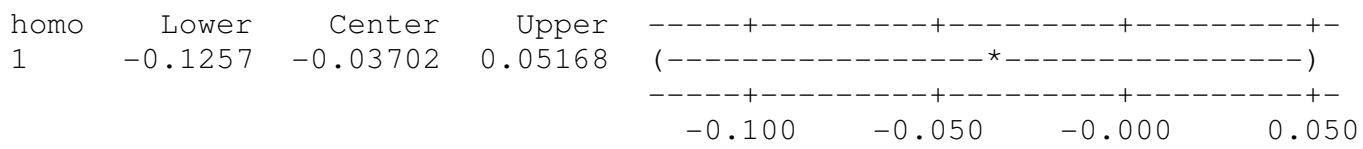

Tukey Simultaneous Tests

Response Variable mean cohesiveness

All Pairwise Comparisons among Levels of homo

homo $=0$ subtracted from:

$\begin{array}{lrrrr} & \text { Difference } & \text { SE of } & \text { Adjusted } \\ \text { homo } & \text { of Means } & \text { Difference } & \text { T-Value } & \text { P-Value } \\ 1 & -0.03702 & 0.03195 & -1.159 & 0.3110\end{array}$

Tukey 95.0\% Simultaneous Confidence Intervals Response Variable mean springiness

All Pairwise Comparisons among Levels of acid acid $=1$ subtracted from:

$\begin{array}{lrrr}\text { acid } & \text { Lower } & \text { Center } & \text { Upper } \\ 2 & -1.709 & -0.0606 & 1.588 \\ 3 & -2.232 & -0.5841 & 1.064\end{array}$

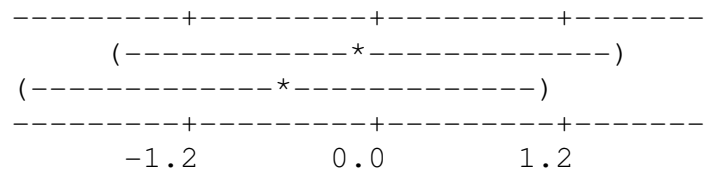

acid $=2$ subtracted from:

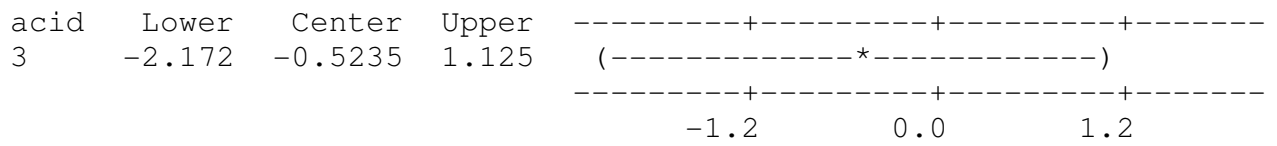

Tukey Simultaneous Tests

Response Variable mean springiness

All Pairwise Comparisons among Levels of acid acid $=1$ subtracted from:

$\begin{array}{lrrrr} & \text { Difference } & \text { SE of } & \text { Adjusted } \\ \text { acid } & \text { of Means } & \text { Difference } & \text { T-Value } & \text { P-Value } \\ 2 & -0.0606 & 0.4625 & -0.131 & 0.9906 \\ 3 & -0.5841 & 0.4625 & -1.263 & 0.4835\end{array}$




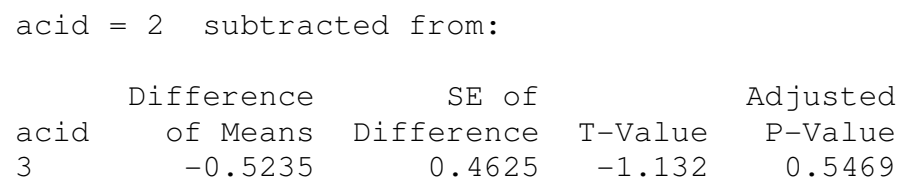

Tukey 95.0\% Simultaneous Confidence Intervals Response Variable mean springiness

All Pairwise Comparisons among Levels of past past $=1$ subtracted from:

$\begin{array}{lrrr}\text { past } & \text { Lower } & \text { Center } & \text { Upper } \\ 2 & -0.546 & 1.1026 & 2.751 \\ 3 & -1.455 & 0.1934 & 1.842\end{array}$

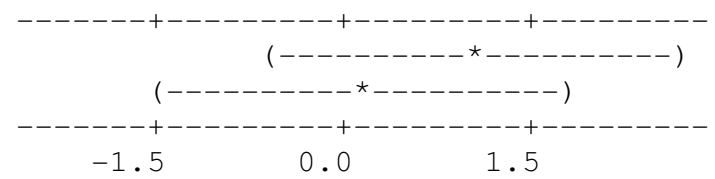

past $=2$ subtracted from:

past Lower Center Upper

$\begin{array}{llll}3 & -2.558 & -0.9093 & 0.7390\end{array}$

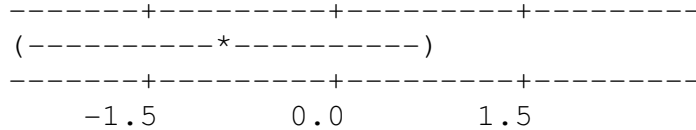

Tukey Simultaneous Tests

Response Variable mean springiness

All Pairwise Comparisons among Levels of past past $=1$ subtracted from:

$\begin{array}{lrrrr} & \text { Difference } & \text { SE of } & \text { Adjusted } \\ \text { past } & \text { of Means } & \text { Difference } & \text { T-Value } & \text { P-Value } \\ 2 & 1.1026 & 0.4625 & 2.3840 & 0.1530 \\ 3 & 0.1934 & 0.4625 & 0.4181 & 0.9102\end{array}$

past $=2$ subtracted from:

\begin{tabular}{|c|c|c|c|c|}
\hline & Difference & $S E$ of & & Ad \\
\hline & $\begin{array}{r}\text { of Means } \\
-0.9093\end{array}$ & $\begin{array}{r}\text { Difference } \\
0.4625\end{array}$ & $\begin{array}{r}\text { T-Value } \\
-1.966\end{array}$ & \\
\hline
\end{tabular}

Tukey 95.0\% Simultaneous Confidence Intervals Response Variable mean springiness

All Pairwise Comparisons among Levels of homo homo $=0$ subtracted from:

\begin{tabular}{|c|c|c|c|c|}
\hline $\begin{array}{l}\text { homo } \\
1\end{array}$ & $\begin{array}{r}\text { Lower } \\
-1.118\end{array}$ & $\begin{array}{r}\text { Center } \\
-0.06985\end{array}$ & $\begin{array}{r}\text { Upper } \\
0.9786\end{array}$ & $\begin{array}{c}---------+---------+---------+------ \\
(-----------------\star----------------)\end{array}$ \\
\hline & & & & 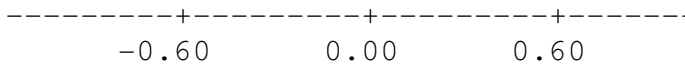 \\
\hline
\end{tabular}

Tukey Simultaneous Tests

Response Variable mean springiness

All Pairwise Comparisons among Levels of homo homo $=0$ subtracted from:

$\begin{array}{crr}\text { Difference } & \text { SE of } & \text { Adjusted } \\ \text { homo of Means } & \text { Difference } & \text { T-Value } \\ \text { P-Value }\end{array}$


Tukey 95.0\% Simultaneous Confidence Intervals Response Variable mean gumminess

All Pairwise Comparisons among Levels of acid acid $=1$ subtracted from:

\begin{tabular}{|c|c|c|c|c|c|c|}
\hline \multirow[t]{2}{*}{$\begin{array}{l}\text { acid } \\
2 \\
3\end{array}$} & \multirow[t]{2}{*}{$\begin{array}{r}\text { Lower } \\
-515.6 \\
-638.1\end{array}$} & $\begin{array}{r}\text { Center } \\
48.19 \\
-74.37\end{array}$ & $\begin{array}{l}\text { Upper } \\
612.0 \\
489.4\end{array}$ & \multicolumn{3}{|c|}{$\begin{array}{r}-------+---------++----------+---- \\
\quad(-------------\star--------------1\end{array}$} \\
\hline & & & & \multirow[t]{2}{*}{-400} & \multirow[t]{2}{*}{0} & \multirow[t]{2}{*}{400} \\
\hline cid & \multicolumn{2}{|c|}{ subtracted } & from: & & & \\
\hline \multirow{3}{*}{$a_{3}^{a c i d}$} & Lower & Center & Upper & \multirow{2}{*}{\multicolumn{3}{|c|}{$\begin{array}{c}--------+----------+----------+- \\
(---------------\star \star---------------)\end{array}$}} \\
\hline & -686.3 & -122.6 & 441.2 & & & \\
\hline & & & & -400 & 0 & 400 \\
\hline
\end{tabular}

Tukey Simultaneous Tests

Response Variable mean gumminess

All Pairwise Comparisons among Levels of acid acid $=1$ subtracted from:

$\begin{array}{lrrrr} & \text { Difference } & \text { SE of } & \text { Adjusted } \\ \text { acid } & \text { of Means } & \text { Difference } & \text { T-Value } & \text { P-Value } \\ 2 & 48.19 & 158.2 & 0.3046 & 0.9507 \\ 3 & -74.37 & 158.2 & -0.4702 & 0.8885\end{array}$

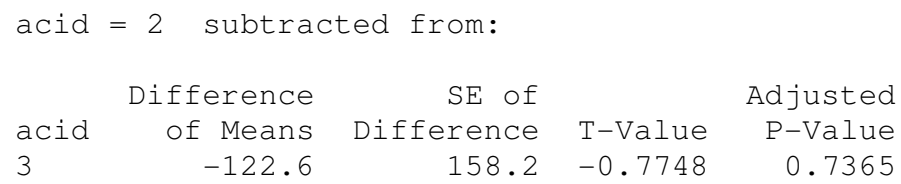

Tukey 95.0\% Simultaneous Confidence Intervals Response Variable mean gumminess

All Pairwise Comparisons among Levels of past past $=1$ subtracted from:

$\begin{array}{lrrr}\text { past } & \text { Lower } & \text { Center } & \text { Upper } \\ 2 & -634.8 & -71.07 & 492.7 \\ 3 & 81.0 & 644.77 & 1208.5\end{array}$
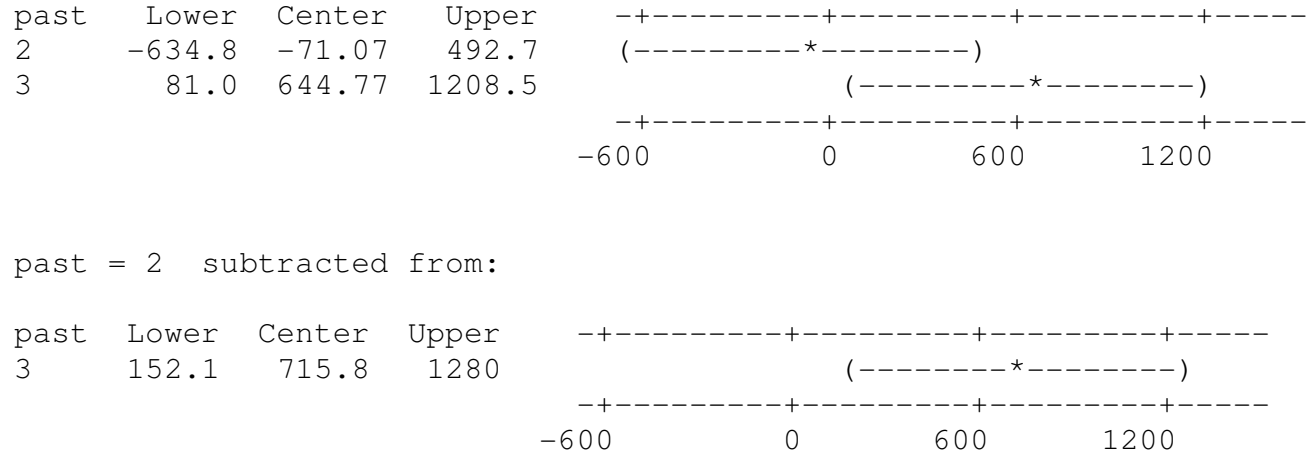

Tukey Simultaneous Tests

Response Variable mean gumminess

All Pairwise Comparisons among Levels of past 


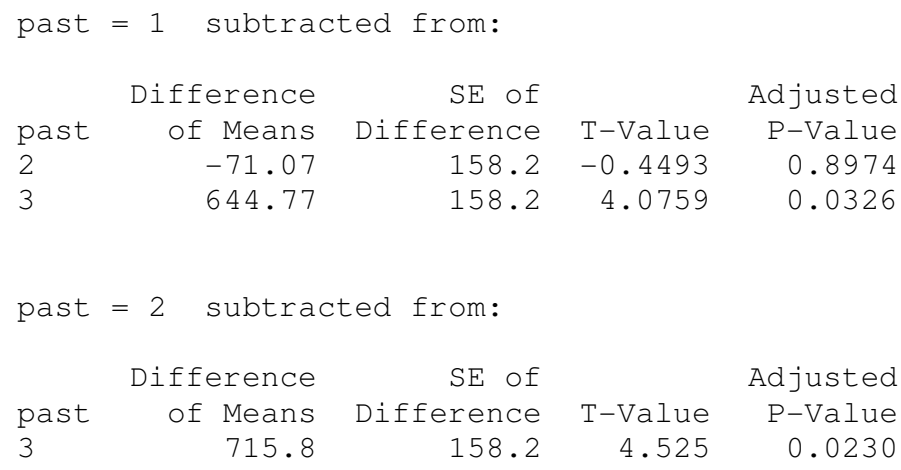

Tukey 95.0\% Simultaneous Confidence Intervals Response Variable mean gumminess

All Pairwise Comparisons among Levels of homo homo $=0$ subtracted from:

homo Lower Center Upper

$\begin{array}{llll}1 & -612.9 & -254.3 & 104.3\end{array}$

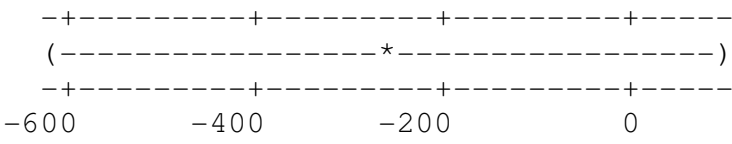

Tukey Simultaneous Tests

Response Variable mean gumminess

All Pairwise Comparisons among Levels of homo homo $=0$ subtracted from:

$\begin{array}{rrrrr} & \text { Difference } & \text { SE of } & \text { Adjusted } \\ \text { homo } & \text { of Means } & \text { Difference } & \text { T-Value } & \text { P-Value } \\ 1 & -254.3 & 129.2 & -1.969 & 0.1203\end{array}$

Tukey 95.0\% Simultaneous Confidence Intervals Response Variable mean chewiness

All Pairwise Comparisons among Levels of acid acid $=1$ subtracted from:

$\begin{array}{lrrr}\text { acid } & \text { Lower } & \text { Center } & \text { Upper } \\ 2 & -3919 & -111.9 & 3695 \\ 3 & -4549 & -741.6 & 3066\end{array}$

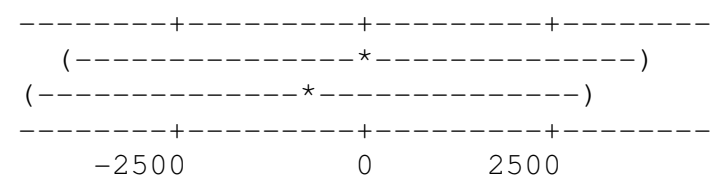

acid $=2$ subtracted from:

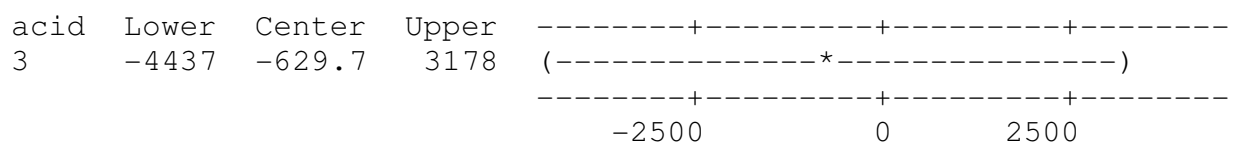

Tukey Simultaneous Tests

Response Variable mean chewiness

All Pairwise Comparisons among Levels of acid acid $=1$ subtracted from:

$\begin{array}{lrrrr} & \text { Difference } & \text { SE of } & \text { Adjusted } \\ \text { acid } & \text { of Means } & \text { Difference } & \text { T-Value } & \text { P-Value } \\ 2 & -111.9 & 1068 & -0.1048 & 0.9940 \\ 3 & -741.6 & 1068 & -0.6942 & 0.7795\end{array}$



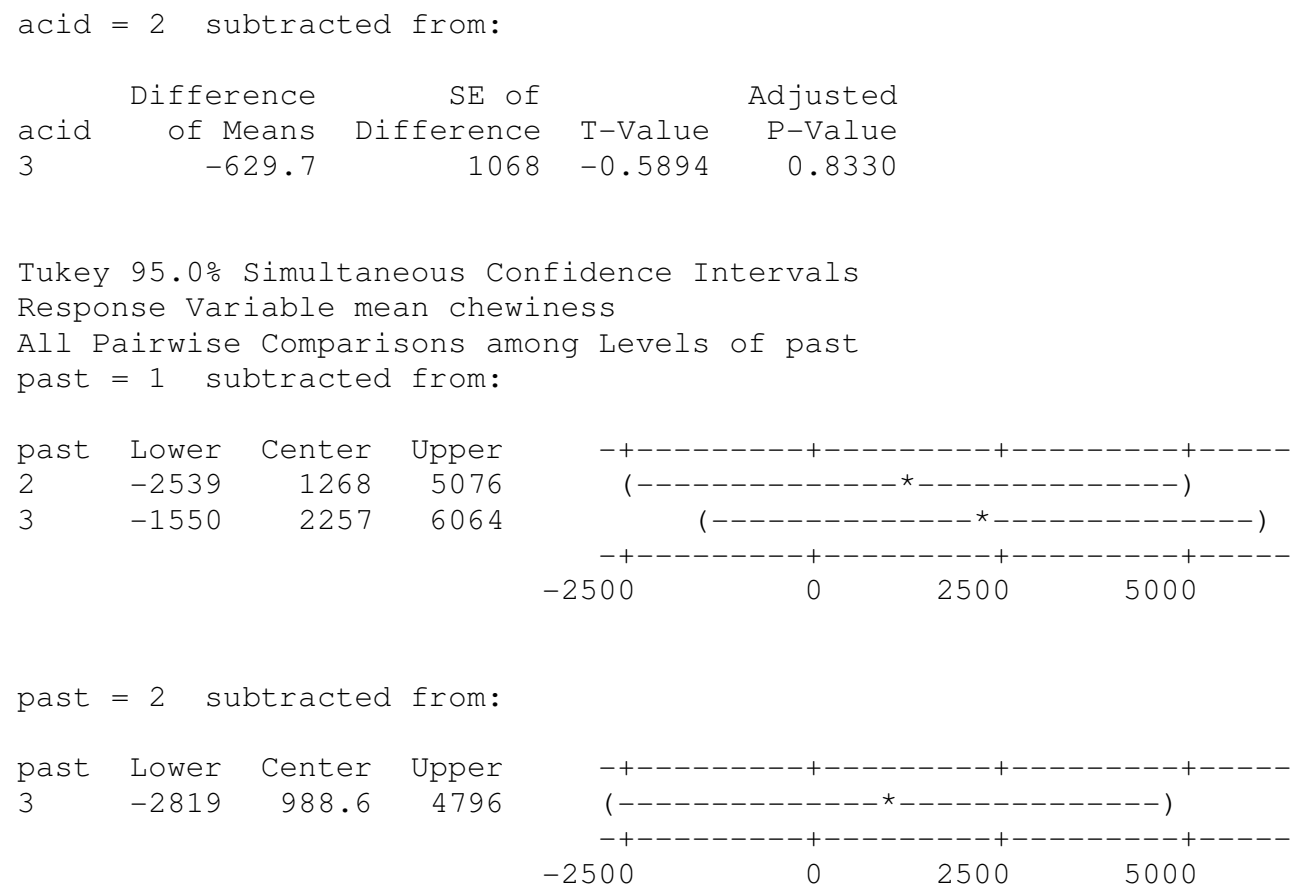

Tukey Simultaneous Tests

Response Variable mean chewiness

All Pairwise Comparisons among Levels of past

past $=1$ subtracted from:

$\begin{array}{lrrrr} & \text { Difference } & \text { SE of } & & \text { Adjusted } \\ \text { past } & \text { of Means } & \text { Difference } & \text { T-Value } & \text { P-Value } \\ 2 & 1268 & 1068 & 1.187 & 0.5196 \\ 3 & 2257 & 1068 & 2.113 & 0.2024\end{array}$

$\begin{array}{lrrrr}\text { past }=2 \text { subtracted from: } & & \\ & \text { Difference } & \text { SE of } & & \text { Adjusted } \\ \text { past } & \text { of Means } & \text { Difference } & \text { T-Value } & \text { P-Value } \\ 3 & 988.6 & 1068 & 0.9254 & 0.6551\end{array}$

Tukey 95.0\% Simultaneous Confidence Intervals Response Variable mean chewiness

All Pairwise Comparisons among Levels of homo homo $=0$ subtracted from:

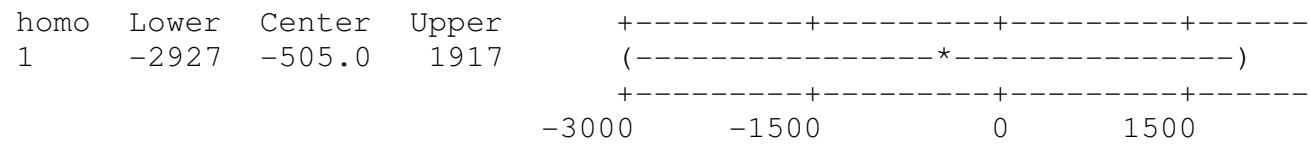

Tukey Simultaneous Tests

Response Variable mean chewiness

All Pairwise Comparisons among Levels of homo homo $=0$ subtracted from:

$\begin{array}{rrrrr} & \text { Difference } & \text { SE of } & \text { Adjusted } \\ \text { homo } & \text { of Means } & \text { Difference } & \text { T-Value } & \text { P-Value } \\ 1 & -505.0 & 872.3 & -0.5789 & 0.5937\end{array}$




\section{Experimental design 2 statistical analysis}

\subsection{General Linear Model for mean protein, mean moisture and mean fat}

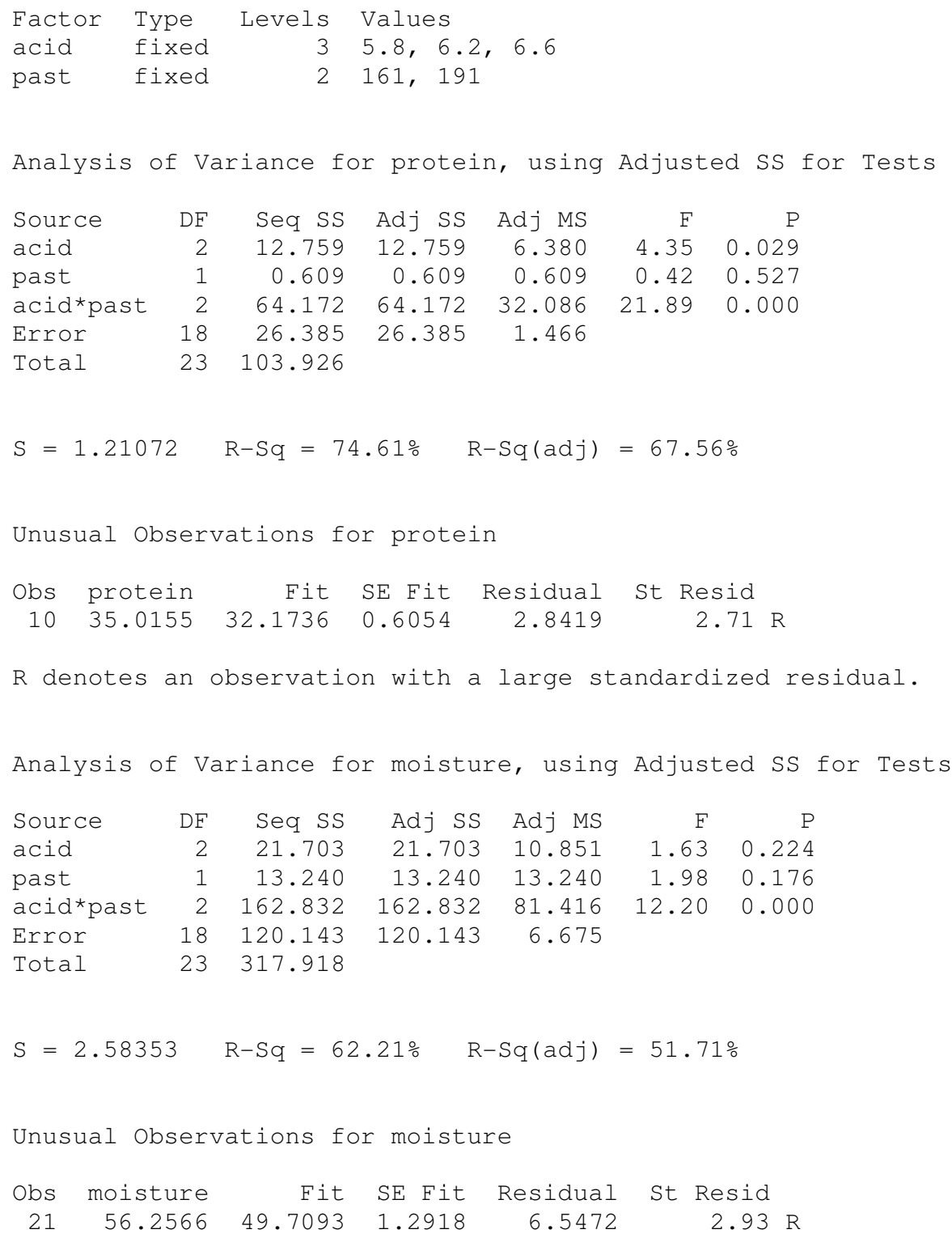


Unusual Observations for fat

$\begin{array}{rrrrrr}\text { Obs } & \text { fat } & \text { Fit } & \text { SE Fit } & \text { Residual } & \text { St Resid } \\ 10 & 11.0000 & 10.3750 & 0.1792 & 0.6250 & 2.01 \mathrm{R} \\ 15 & 10.0000 & 10.6250 & 0.1792 & -0.6250 & -2.01 \mathrm{R}\end{array}$

$\mathrm{R}$ denotes an observation with a large standardized residual.

Tukey 95.0\% Simultaneous Confidence Intervals

Response Variable protein

All Pairwise Comparisons among Levels of acid

acid $=5.8$ subtracted from:

$\begin{array}{lrrr}\text { acid } & \text { Lower } & \text { Center } & \text { Upper } \\ 6.2 & -1.394 & 0.151 & 1.69663 \\ 6.6 & -3.011 & -1.465 & 0.07981\end{array}$

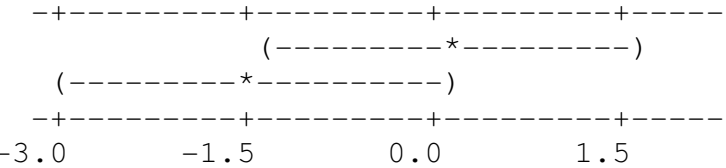

acid $=6.2$ subtracted from:

acid Lower Center Upper

$\begin{array}{llll}6.6 & -3.162 & -1.617 & -0.07154\end{array}$

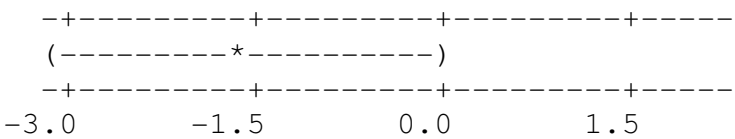

Tukey 95.0\% Simultaneous Confidence Intervals

Response Variable protein

All Pairwise Comparisons among Levels of past

past $=161$ subtracted from:

past Lower Center Upper

$\begin{array}{llll}191 & -1.357 & -0.3187 & 0.7198\end{array}$

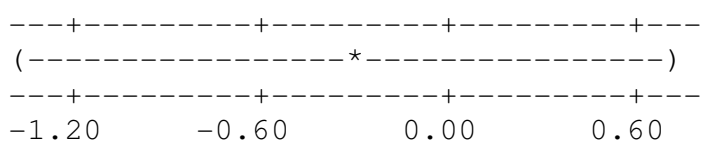

Tukey 95.0\% Simultaneous Confidence Intervals

Response Variable protein

All Pairwise Comparisons among Levels of acid*past

acid $=5.8$

past $=161$ subtracted from:

$\begin{array}{llrrr}\text { acid } & \text { past } & \text { Lower } & \text { Center } & \text { Uppe } \\ 5.8 & 191 & -7.635 & -4.917 & -2.19 \\ 6.2 & 161 & -6.230 & -3.512 & -0.79 \\ 6.2 & 191 & -3.821 & -1.103 & 1.61 \\ 6.6 & 161 & -7.418 & -4.700 & -1.98 \\ 6.6 & 191 & -5.866 & -3.148 & -0.43\end{array}$

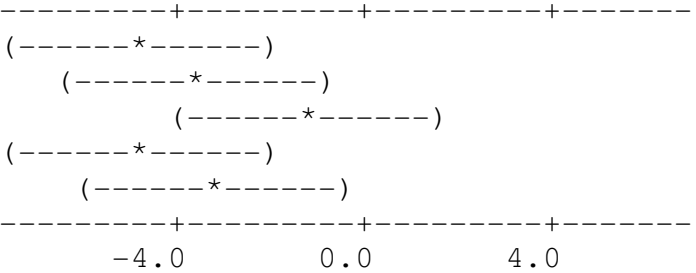

acid $=5.8$

past $=191$ subtracted from:

acid past Lower Center Upper

$\begin{array}{lllll}6.2 & 161 & -1.313 & 1.4055 & 4.124\end{array}$

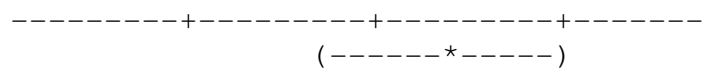




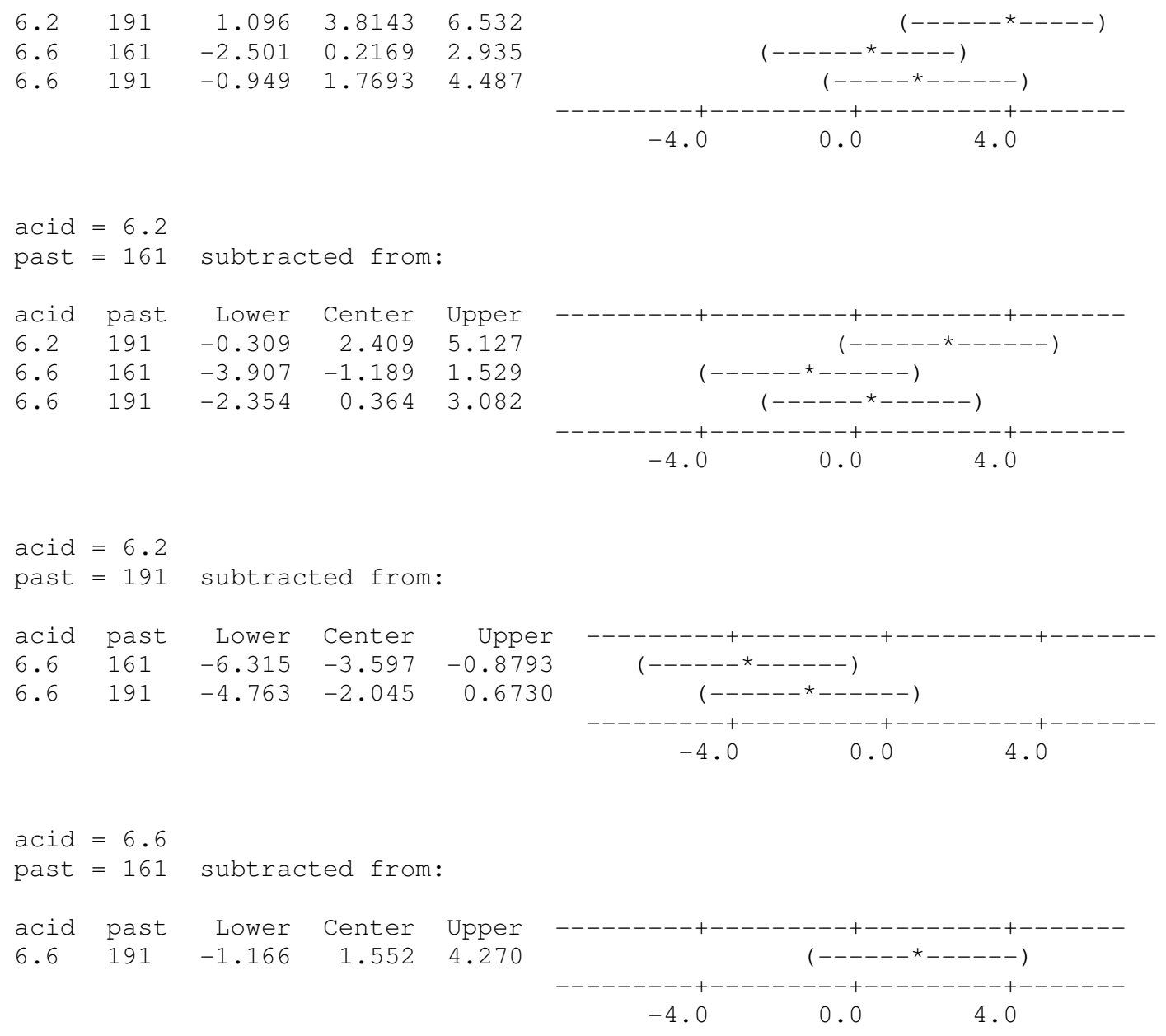

Tukey 95.0\% Simultaneous Confidence Intervals Response Variable moisture

All Pairwise Comparisons among Levels of acid acid $=5.8$ subtracted from:
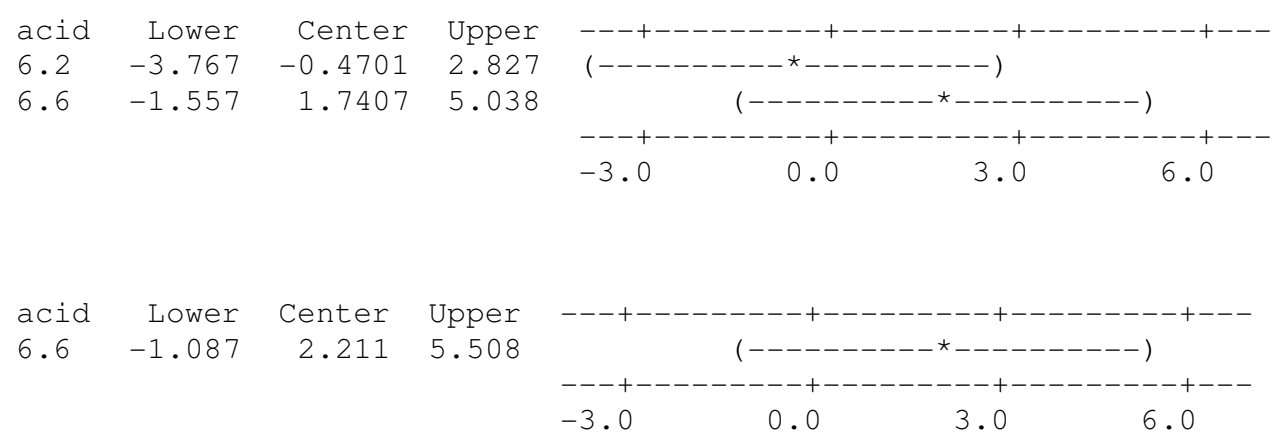

Tukey 95.0\% Simultaneous Confidence Intervals Response Variable moisture

All Pairwise Comparisons among Levels of past past $=161$ subtracted from:

past Lower Center Upper ------+---------+---------+---------+ 


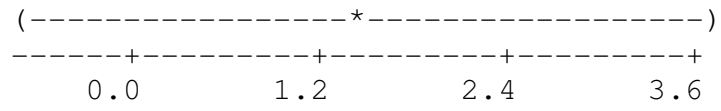

Tukey 95.0\% Simultaneous Confidence Intervals

Response Variable moisture

All Pairwise Comparisons among Levels of acid*past

acid $=5.8$

past $=161$ subtracted from:

$\begin{array}{llrrr}\text { acid } & \text { past } & \text { Lower } & \text { Center } & \text { Upper } \\ 5.8 & 191 & 2.948 & 8.748 & 14.548 \\ 6.2 & 161 & -0.287 & 5.513 & 11.313 \\ 6.2 & 191 & -3.505 & 2.295 & 8.095 \\ 6.6 & 161 & 0.851 & 6.651 & 12.451 \\ 6.6 & 191 & -0.222 & 5.578 & 11.378\end{array}$

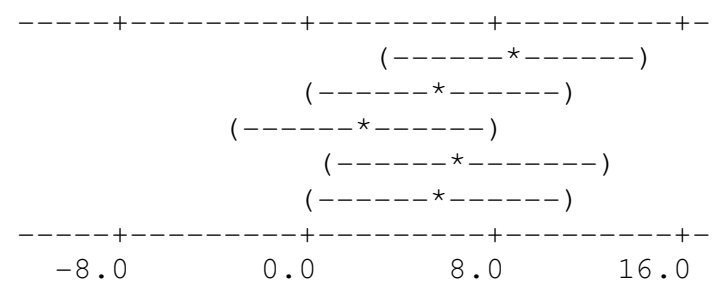

acid $=5.8$

past $=191$ subtracted from:

acid past Lower Center Upper

$\begin{array}{lllll}6.2 & 161 & -9.03 & -3.235 & 2.5652\end{array}$

6.2191

6.6161

$-12.25-6.453$

$-0.6532$

6.6191

$-8.97-3.170$

3.7033

2.6303

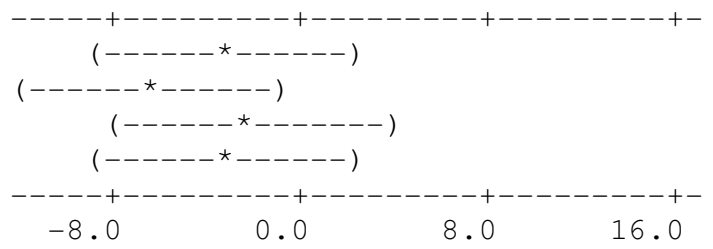

acid $=6.2$

past $=161$

subtracted from:

$\begin{array}{llrrr}\text { acid } & \text { past } & \text { Lower } & \text { Center } & \text { Upper } \\ 6.2 & 191 & -9.018 & -3.218 & 2.582 \\ 6.6 & 161 & -4.662 & 1.138 & 6.938 \\ 6.6 & 191 & -5.735 & 0.065 & 5.865\end{array}$

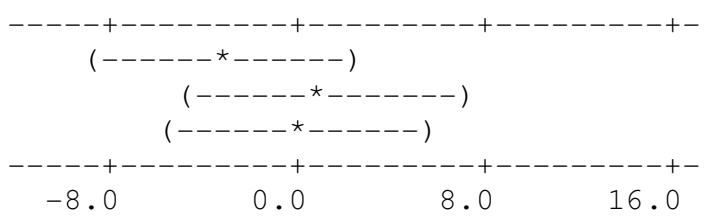

acid $=6.2$

past $=191$

subtracted from:

$\begin{array}{llrr}\text { acid } & \text { past } & \text { Lower } & \text { Center } \\ 6.6 & 161 & -1.444 & 4.357 \\ 6.6 & 191 & -2.517 & 3.283\end{array}$

Upper

10.157

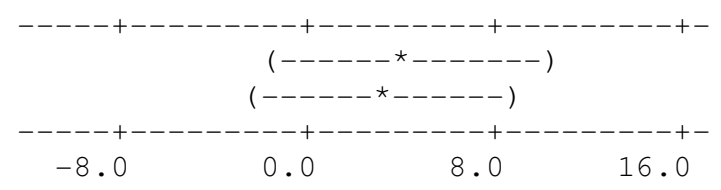

acid $=6.6$

past $=161$ subtracted from:

acid past Lower Center Upper $\begin{array}{lllll}6.6 & 191 & -6.873 & -1.073 & 4.727\end{array}$

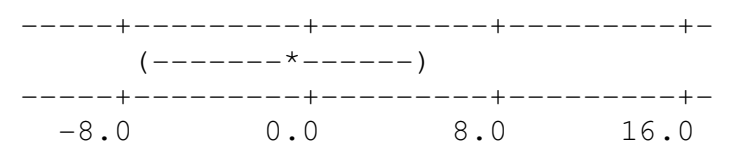


Tukey 95.0\% Simultaneous Confidence Intervals Response Variable fat

All Pairwise Comparisons among Levels of acid acid $=5.8$ subtracted from:

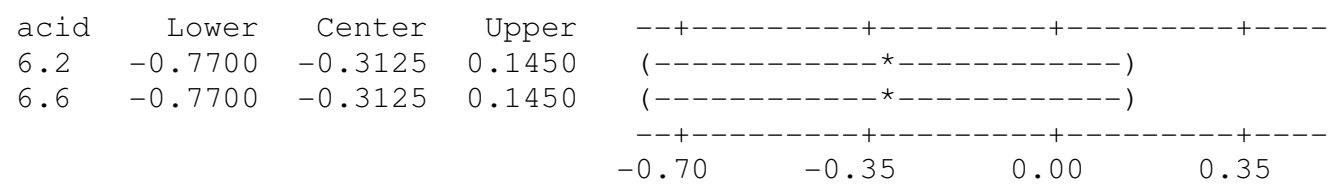

acid $=6.2$ subtracted from:

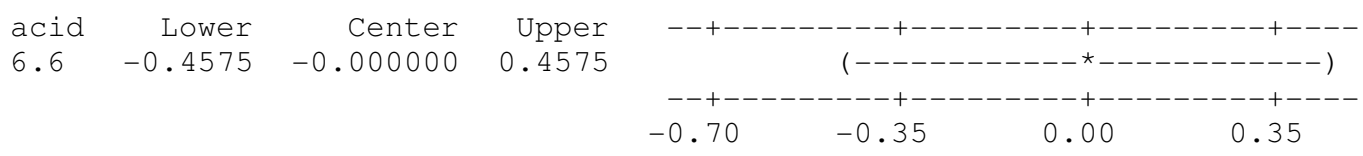

Tukey 95.0\% Simultaneous Confidence Intervals Response Variable fat All Pairwise Comparisons among Levels of past past $=161$ subtracted from:

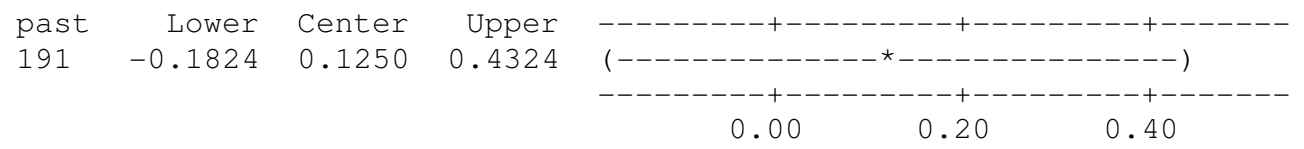

Tukey 95.0\% Simultaneous Confidence Intervals

Response Variable fat

All Pairwise Comparisons among Levels of acid*past

acid $=5.8$

past $=161$ subtracted from:

$\begin{array}{llrrr}\text { acid } & \text { past } & \text { Lower } & \text { Center } & \text { Upper } \\ 5.8 & 191 & -0.680 & 0.1250 & 0.9297 \\ 6.2 & 161 & -0.930 & -0.1250 & 0.6797 \\ 6.2 & 191 & -1.180 & -0.3750 & 0.4297 \\ 6.6 & 161 & -1.305 & -0.5000 & 0.3047 \\ 6.6 & 191 & -0.805 & 0.0000 & 0.8047\end{array}$

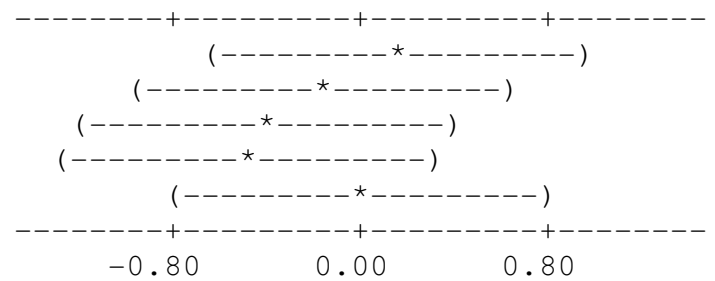

acid $=5.8$

past $=191$ subtracted from:

acid past Lower Center Upper

$\begin{array}{llll}6.2 & 161 & -1.055 & -0.2500\end{array}$

$\begin{array}{llll}6.2 & 191 & -1.305 & -0.5000\end{array}$

$\begin{array}{llll}6.6 & 161 & -1.430 & -0.6250\end{array}$

0.5547

6.6191

$-0.930-0.1250$

0.3047

0.1797

0.6797

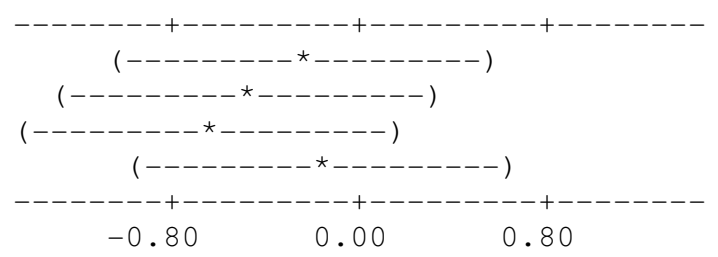

acid $=6.2$

past $=161$ subtracted from:

acid past Lower Center Upper 


$\begin{array}{lllrl}6.2 & 191 & -1.055 & -0.2500 & 0.5547 \\ 6.6 & 161 & -1.180 & -0.3750 & 0.4297 \\ 6.6 & 191 & -0.680 & 0.1250 & 0.9297\end{array}$

acid $=6.2$

past $=191$ subtracted from:

acid past Lower Center

$\begin{array}{llll}6.6 & 161 & -0.9297 & -0.1250\end{array}$

$\begin{array}{llll}6.6 & 191 & -0.4297 & 0.3750\end{array}$

Upper
0.6797
1.1797

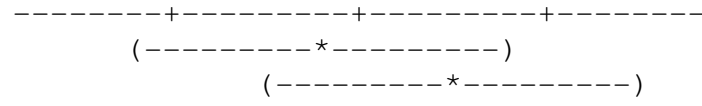

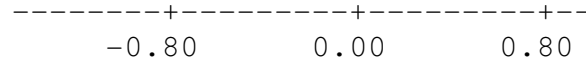

acid $=6.6$

past $=161$

acid past

6.6191 subtracted from:

$\begin{array}{rrr}\text { Lower } & \text { Center } & \text { Upper } \\ -0.3047 & 0.5000 & 1.305\end{array}$

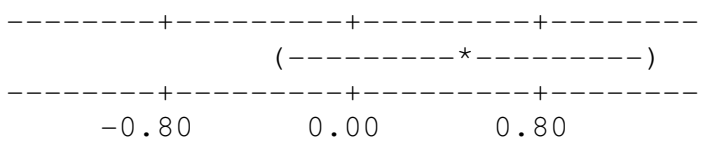

\section{2,2 General Linear Model for flow oven, flow microwave and mean hot water}

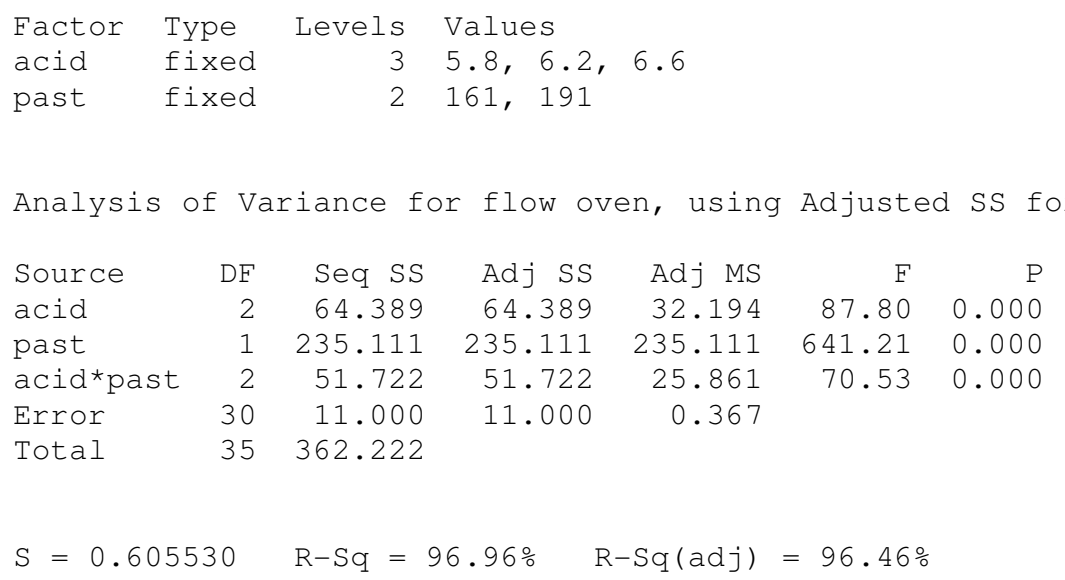

Analysis of Variance for flow microwave, using Adjusted SS for Tests

$\begin{array}{lrrrrrr}\text { Source } & \text { DF } & \text { Seq SS } & \text { Adj SS } & \text { Adj MS } & \text { F } & \text { P } \\ \text { acid } & 2 & 43.167 & 43.167 & 21.583 & 7.69 & 0.002 \\ \text { past } & 1 & 220.028 & 220.028 & 220.028 & 78.43 & 0.000 \\ \text { acid*past } & 2 & 35.389 & 35.389 & 17.694 & 6.31 & 0.005 \\ \text { Error } & 30 & 84.167 & 84.167 & 2.806 & & \\ \text { Total } & 35 & 382.750 & & & & \end{array}$

$S=1.67498 \quad R-S q=78.01 \% \quad R-S q(\operatorname{adj})=74.35 \%$

Unusual Observations for flow microwave

flow 


$\begin{array}{rrrrrr}\text { Obs } & \text { microwave } & \text { Fit } & \text { SE Fit } & \text { Residual } & \text { St Resid } \\ 26 & 2.00000 & 6.33333 & 0.68381 & -4.33333 & -2.83 \mathrm{R} \\ 27 & 2.00000 & 6.33333 & 0.68381 & -4.33333 & -2.83 \mathrm{R}\end{array}$

R denotes an observation with a large standardized residual.

Analysis of Variance for flow hot water, using Adjusted sS for Tests

$\begin{array}{lrrrrrr}\text { Source } & \text { DF } & \text { Seq SS } & \text { Adj SS } & \text { Adj MS } & F & P \\ \text { acid } & 2 & 14.389 & 14.389 & 7.194 & 9.32 & 0.001 \\ \text { past } & 1 & 210.250 & 210.250 & 210.250 & 272.27 & 0.000 \\ \text { acid*past } & 2 & 13.167 & 13.167 & 6.583 & 8.53 & 0.001 \\ \text { Error } & 30 & 23.167 & 23.167 & 0.772 & & \\ \text { Total } & 35 & 260.972 & & & & \\ & & & & & \\ \text { S }=0.878762 & \text { R-Sq }=91.12 \% & \text { R-Sq(adj) }=89.64 \%\end{array}$

Unusual Observations for flow hot water

\begin{tabular}{|c|c|c|c|c|c|c|}
\hline & flow hot & $\mathrm{Fit}$ & $\mathrm{SF} F i t$ & Residual & St & sid \\
\hline 4 & 1.00000 & 3.16667 & 0.35875 & -2.16667 & & $-2.70 \mathrm{R}$ \\
\hline 22 & 5.00000 & 3.16667 & 0.35875 & 1.83333 & & $2.29 \mathrm{R}$ \\
\hline 24 & 5.00000 & 3.16667 & 0.35875 & 1.83333 & & 2.29 \\
\hline
\end{tabular}

$\mathrm{R}$ denotes an observation with a large standardized residual.

Tukey 95.0\% Simultaneous Confidence Intervals

Response Variable flow oven

All Pairwise Comparisons among Levels of acid

acid $=5.8$ subtracted from:

acid Lower Center Upper

$\begin{array}{llll}6.2 & -3.360 & -2.750 & -2.140\end{array}$

$\begin{array}{llll}6.6 & -0.443 & 0.167 & 0.777\end{array}$

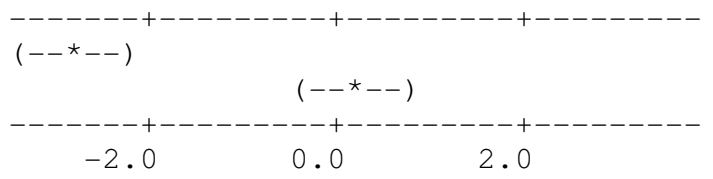

acid $=6.2$ subtracted from:

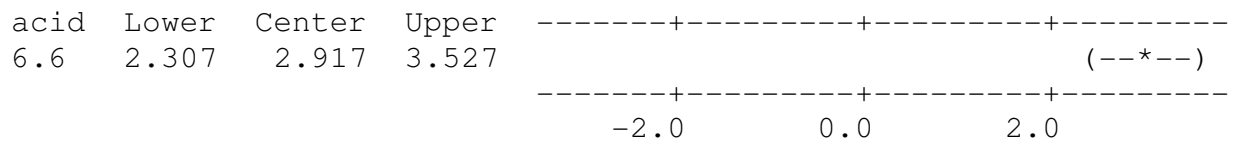

Tukey Simultaneous Tests

Response Variable flow oven

All Pairwise Comparisons among Levels of acid

acid $=5.8$ subtracted from:

$\begin{array}{lrrrr} & \text { Difference } & \text { SE of } & & \text { Adjusted } \\ \text { acid } & \text { of Means } & \text { Difference } & \text { T-Value } & \text { P-Value } \\ 6.2 & -2.750 & 0.2472 & -11.12 & 0.0000 \\ 6.6 & 0.167 & 0.2472 & 0.67 & 0.7801\end{array}$

acid $=6.2$ subtracted from: 


$\begin{array}{lrrrr} & \text { Difference } & \text { SE of } & & \text { Adjusted } \\ \text { acid } & \text { of Means } & \text { Difference } & \text { T-Value } & \text { P-Value } \\ 6.6 & 2.917 & 0.2472 & 11.80 & 0.0000\end{array}$

Tukey 95.0\% Simultaneous Confidence Intervals Response Variable flow oven

All Pairwise Comparisons among Levels of past past $=161$ subtracted from:

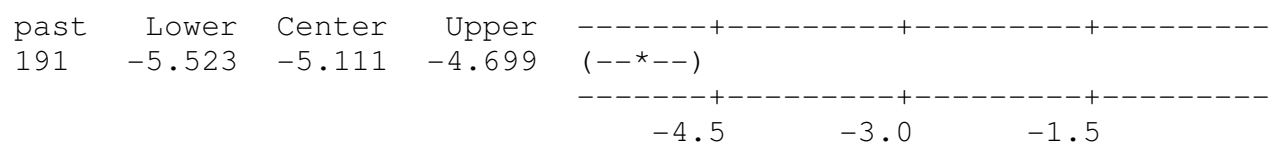

Tukey Simultaneous Tests Response Variable flow oven All Pairwise Comparisons among Levels of past past $=161$ subtracted from:

$\begin{array}{lrrrr} & \text { Difference } & \text { SE of } & & \text { Adjusted } \\ \text { past } & \text { of Means } & \text { Difference } & \text { T-Value } & \text { P-Value } \\ 191 & -5.111 & 0.2018 & -25.32 & 0.0000\end{array}$

Tukey 95.0\% Simultaneous Confidence Intervals

Response Variable flow oven

All Pairwise Comparisons among Levels of acid*past

acid $=5.8$

past $=161$ subtracted from:

acid past Lower Center Upper

$\begin{array}{lllll}5.8 & 191 & -8.896 & -7.833 & -6.770\end{array}$

$\begin{array}{lllll}6.2 & 161 & -6.730 & -5.667 & -4.604\end{array}$

$\begin{array}{lllll}6.2 & 191 & -8.730 & -7.667 & -6.604\end{array}$

$\begin{array}{lllll}6.6 & 161 & -2.063 & -1.000 & 0.063\end{array}$

$\begin{array}{lllll}6.6 & 191 & -7.563 & -6.500 & -5.437\end{array}$

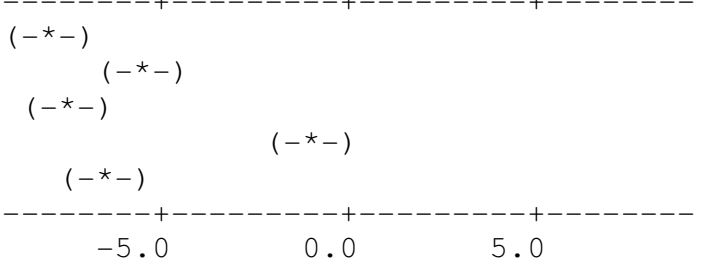

acid $=5.8$

past $=191$ subtracted from:

acid past Lower Center Upper

$\begin{array}{lllll}6.2 & 161 & 1.1037 & 2.1667 & 3.230\end{array}$

$\begin{array}{lllll}6.2 & 191 & -0.8963 & 0.1667 & 1.230\end{array}$

$\begin{array}{lllll}6.6 & 161 & 5.7703 & 6.8333 & 7.896\end{array}$

$\begin{array}{lllll}6.6 & 191 & 0.2703 & 1.3333 & 2.396\end{array}$

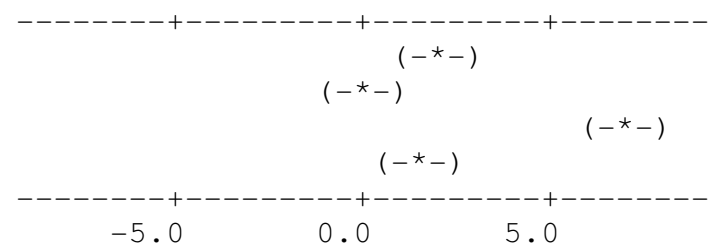

acid $=6.2$

past $=161$

subtracted from:

$\begin{array}{llrrr}\text { acid } & \text { past } & \text { Lower } & \text { Center } & \text { Upper } \\ 6.2 & 191 & -3.063 & -2.000 & -0.9370 \\ 6.6 & 161 & 3.604 & 4.667 & 5.7297 \\ 6.6 & 191 & -1.896 & -0.833 & 0.2297\end{array}$

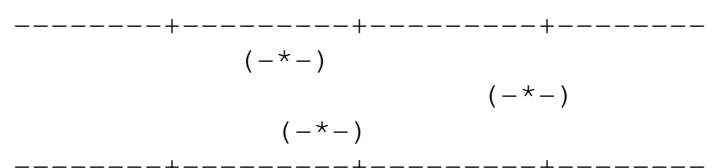




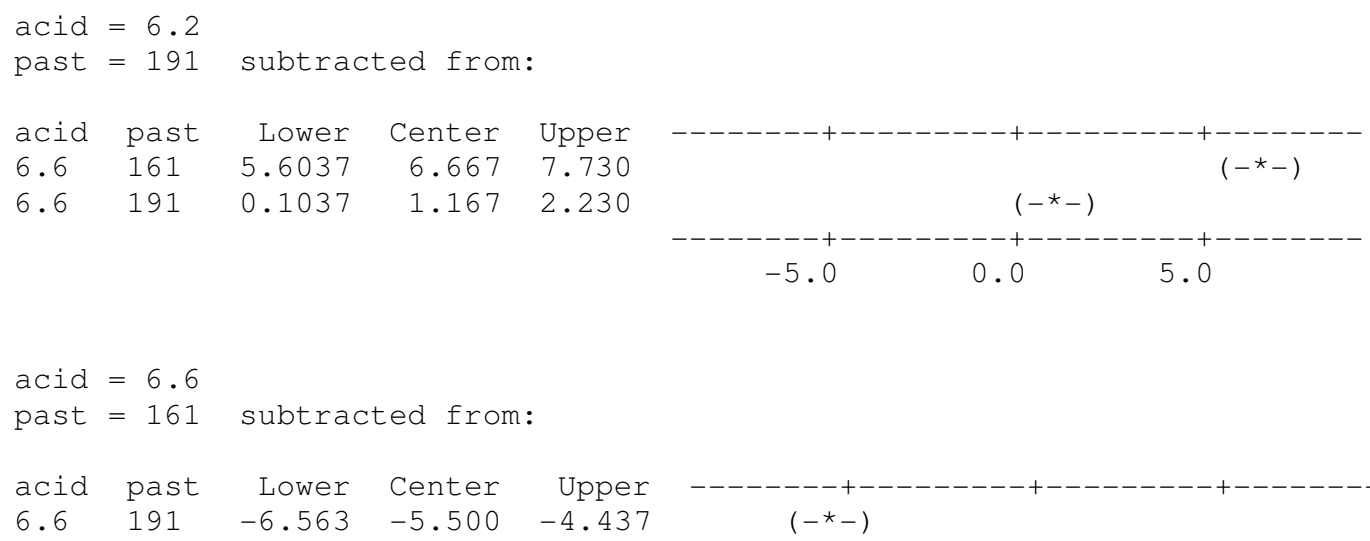

Tukey Simultaneous Tests

Response Variable flow oven

All Pairwise Comparisons among Levels of acid*past acid $=5.8$ 


\begin{tabular}{|c|c|c|c|c|c|}
\hline 6.6 & 161 & 6.667 & 0.3496 & 19.069 & 0.0000 \\
\hline 6.6 & 191 & 1.167 & 0.3496 & 3.337 & 0.0250 \\
\hline $\begin{array}{l}\text { acid } \\
\text { past }\end{array}$ & $\begin{array}{l}=6.6 \\
=161\end{array}$ & subtracted & from: & & \\
\hline & & Difference & $S E$ of & & Adjuste \\
\hline acid & past & of Means & Difference & T-Value & P-Value \\
\hline 6.6 & 191 & -5.500 & 0.3496 & $-15 \cdot 73$ & 0.0000 \\
\hline
\end{tabular}

Tukey 95.0\% Simultaneous Confidence Intervals Response Variable flow microwave

All Pairwise Comparisons among Levels of acid acid $=5.8$ subtracted from:

acid Lower Center Upper

$\begin{array}{lllll}6.2 & -3.604 & -1.917 & -0.2292\end{array}$

$\begin{array}{llll}6.6 & -1.021 & 0.667 & 2.3542\end{array}$

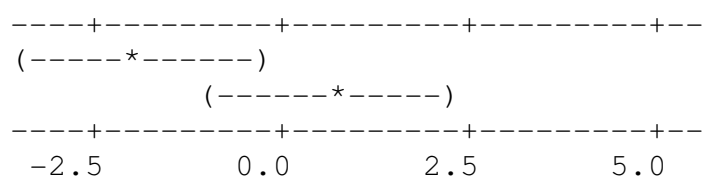

acid $=6.2$ subtracted from:

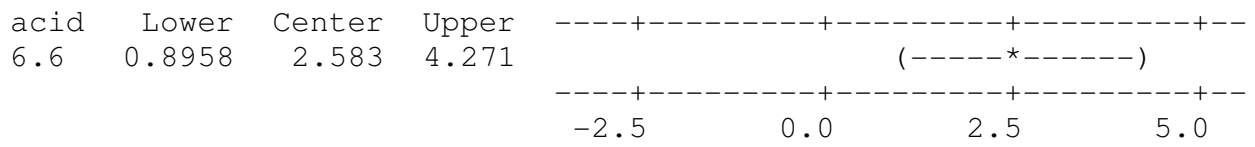

Tukey Simultaneous Tests

Response Variable flow microwave

All Pairwise Comparisons among Levels of acid

acid $=5.8$ subtracted from:

$\begin{array}{lrrrr} & \text { Difference } & \text { SE of } & & \text { Adjusted } \\ \text { acid } & \text { of Means } & \text { Difference } & \text { T-Value } & \text { P-Value } \\ 6.2 & -1.917 & 0.6838 & -2.803 & 0.0232 \\ 6.6 & 0.667 & 0.6838 & 0.975 & 0.5981\end{array}$

acid $=6.2$ subtracted from:

$\begin{array}{lrrrr} & \text { Difference } & \text { SE of } & & \text { Adjusted } \\ \text { acid } & \text { of Means } & \text { Difference } & \text { T-Value } & \text { P-Value } \\ 6.6 & 2.583 & 0.6838 & 3.778 & 0.0020\end{array}$

Tukey 95.0\% Simultaneous Confidence Intervals Response Variable flow microwave

All Pairwise Comparisons among Levels of past past $=161$ subtracted from:

past Lower Center Upper

$\begin{array}{llll}191 & -6.085 & -4.944 & -3.804\end{array}$

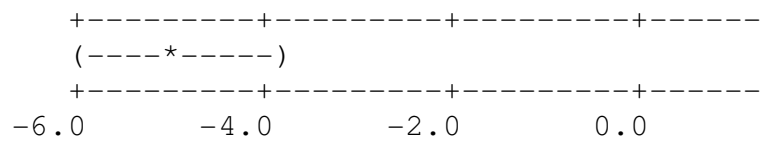

Tukey Simultaneous Tests

Response Variable flow microwave 
All Pairwise Comparisons among Levels of past past $=161$ subtracted from:

$\begin{array}{lrrrr} & \text { Difference } & \text { SE of } & \text { Adjusted } \\ \text { past } & \text { of Means } & \text { Difference } & \text { T-Value } & \text { P-Value } \\ 191 & -4.944 & 0.5583 & -8.856 & 0.0000\end{array}$

Tukey 95.0\% Simultaneous Confidence Intervals

Response Variable flow microwave

All Pairwise Comparisons among Levels of acid*past

acid $=5.8$

past $=161$ subtracted from:

acid past Lower Center Upper

$\begin{array}{lllll}5.8 & 191 & -10.61 & -7.667 & -4.726\end{array}$

$\begin{array}{lllll}6.2 & 161 & -6.61 & -3.667 & -0.726\end{array}$

$\begin{array}{lllll}6.2 & 191 & -10.77 & -7.833 & -4.893\end{array}$

$\begin{array}{lllll}6.6 & 161 & -4.61 & -1.667 & 1.274\end{array}$

$\begin{array}{lllll}6.6 & 191 & -7.61 & -4.667 & -1.726\end{array}$

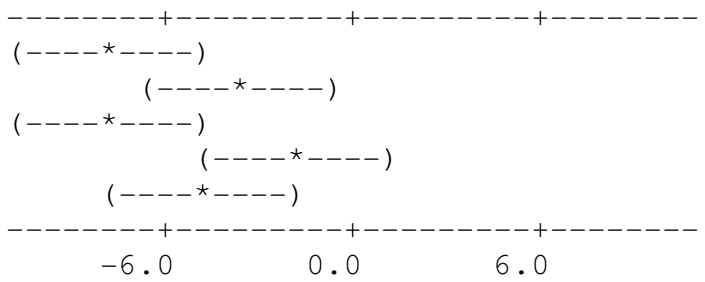

acid $=5.8$

past $=191$ subtracted from:

$\begin{array}{llrrr}\text { acid } & \text { past } & \text { Lower } & \text { Center } & \text { Upper } \\ 6.2 & 161 & 1.060 & 4.0000 & 6.940 \\ 6.2 & 191 & -3.107 & -0.1667 & 2.774 \\ 6.6 & 161 & 3.060 & 6.0000 & 8.940 \\ 6.6 & 191 & 0.060 & 3.0000 & 5.940\end{array}$

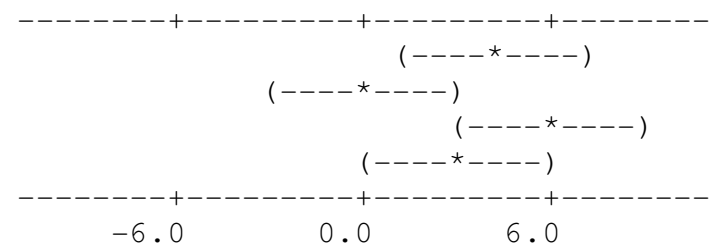

acid $=6.2$

past $=161$

subtracted from:

$\begin{array}{llrrr}\text { acid } & \text { past } & \text { Lower } & \text { Center } & \text { Upper } \\ 6.2 & 191 & -7.107 & -4.167 & -1.226 \\ 6.6 & 161 & -0.940 & 2.000 & 4.940 \\ 6.6 & 191 & -3.940 & -1.000 & 1.940\end{array}$

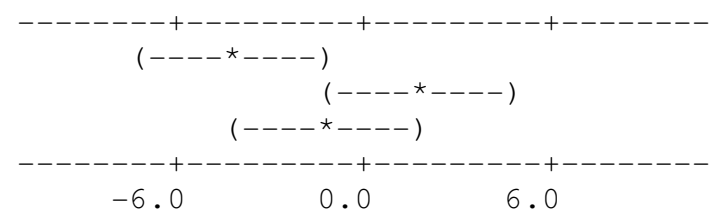

acid $=6.2$

past $=191$

subtracted from:

$\begin{array}{llrrr}\text { acid } & \text { past } & \text { Lower } & \text { Center } & \text { Upper } \\ 6.6 & 161 & 3.2263 & 6.167 & 9.107 \\ 6.6 & 191 & 0.2263 & 3.167 & 6.107\end{array}$

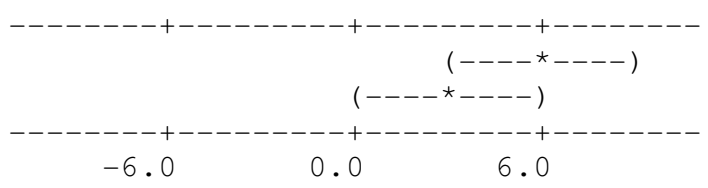

acid $=6.6$

past $=161$ subtracted from:

$\begin{array}{llrrrr}\text { acid } & \text { past } & \text { Lower } & \text { Center } & \text { Upper } & --------+---------+---------+------- \\ 6.6 & 191 & -5.940 & -3.000 & -0.05963 & (----\star----)\end{array}$ 
$\begin{array}{rll}-6.0 & 0.0 & 6.0\end{array}$

Tukey Simultaneous Tests

Response Variable flow microwave

All Pairwise Comparisons among Levels of acid*past acid $=5.8$

past $=161$ subtracted from:

\begin{tabular}{llrrrr} 
& \multicolumn{3}{c}{ Difference } & SE of & Adjusted \\
acid & past & of Means & Difference & T-Value & P-Value \\
5.8 & 191 & -7.667 & 0.9670 & -7.928 & 0.0000 \\
6.2 & 161 & -3.667 & 0.9670 & -3.792 & 0.0081 \\
6.2 & 191 & -7.833 & 0.9670 & -8.100 & 0.0000 \\
6.6 & 161 & -1.667 & 0.9670 & -1.723 & 0.5278 \\
6.6 & 191 & -4.667 & 0.9670 & -4.826 & 0.0005
\end{tabular}

acid $=5.8$

past $=191$ subtracted from:

$\begin{array}{llrrrr} & & \text { Difference } & \text { SE of } & \text { Adjusted } \\ \text { acid } & \text { past } & \text { of Means } & \text { Difference } & \text { T-Value } & \text { P-Value } \\ 6.2 & 161 & 4.0000 & 0.9670 & 4.1363 & 0.0033 \\ 6.2 & 191 & -0.1667 & 0.9670 & -0.1723 & 1.0000 \\ 6.6 & 161 & 6.0000 & 0.9670 & 6.2044 & 0.0000\end{array}$

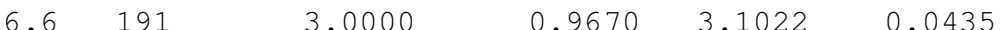

acid $=6.2$

past $=161$ subtracted from:

\begin{tabular}{llrrrr} 
acid & \multicolumn{2}{c}{ pifference } & SE of & Adjusted \\
6.2 & 191 & of Means & Difference & T-Value & P-Value \\
6.6 & 161 & -4.167 & 0.9670 & -4.309 & 0.0021 \\
6.6 & 191 & 2.000 & 0.9670 & 2.068 & 0.3303 \\
& & -1.000 & 0.9670 & -1.034 & 0.9026
\end{tabular}

acid $=6.2$

past $=191$ subtracted from:

$\begin{array}{llrrrr} & & \text { Difference } & \text { SE of } & \text { Adjusted } \\ \text { acid } & \text { past } & \text { of Means } & \text { Difference } & \text { T-Value } & \text { P-Value } \\ 6.6 & 161 & 6.167 & 0.9670 & 6.377 & 0.0000 \\ 6.6 & 191 & 3.167 & 0.9670 & 3.275 & 0.0291\end{array}$

acid $=6.6$

past $=161$ subtracted from:

\begin{tabular}{llrrrr} 
& \multicolumn{1}{c}{ Difference } & SE of & Adjusted \\
acid & past & of Means & Difference & T-Value & P-Value \\
6.6 & 191 & -3.000 & 0.9670 & -3.102 & 0.0435
\end{tabular}

Tukey 95.0\% Simultaneous Confidence Intervals Response Variable flow hot water

All Pairwise Comparisons among Levels of acid acid $=5.8$ subtracted from:

acid Lower Center Upper ---------+---------+---------+-------

$6.2-2.302-1.417 \quad-0.5313 \quad\left(-----\star_{-}------\right)$ 

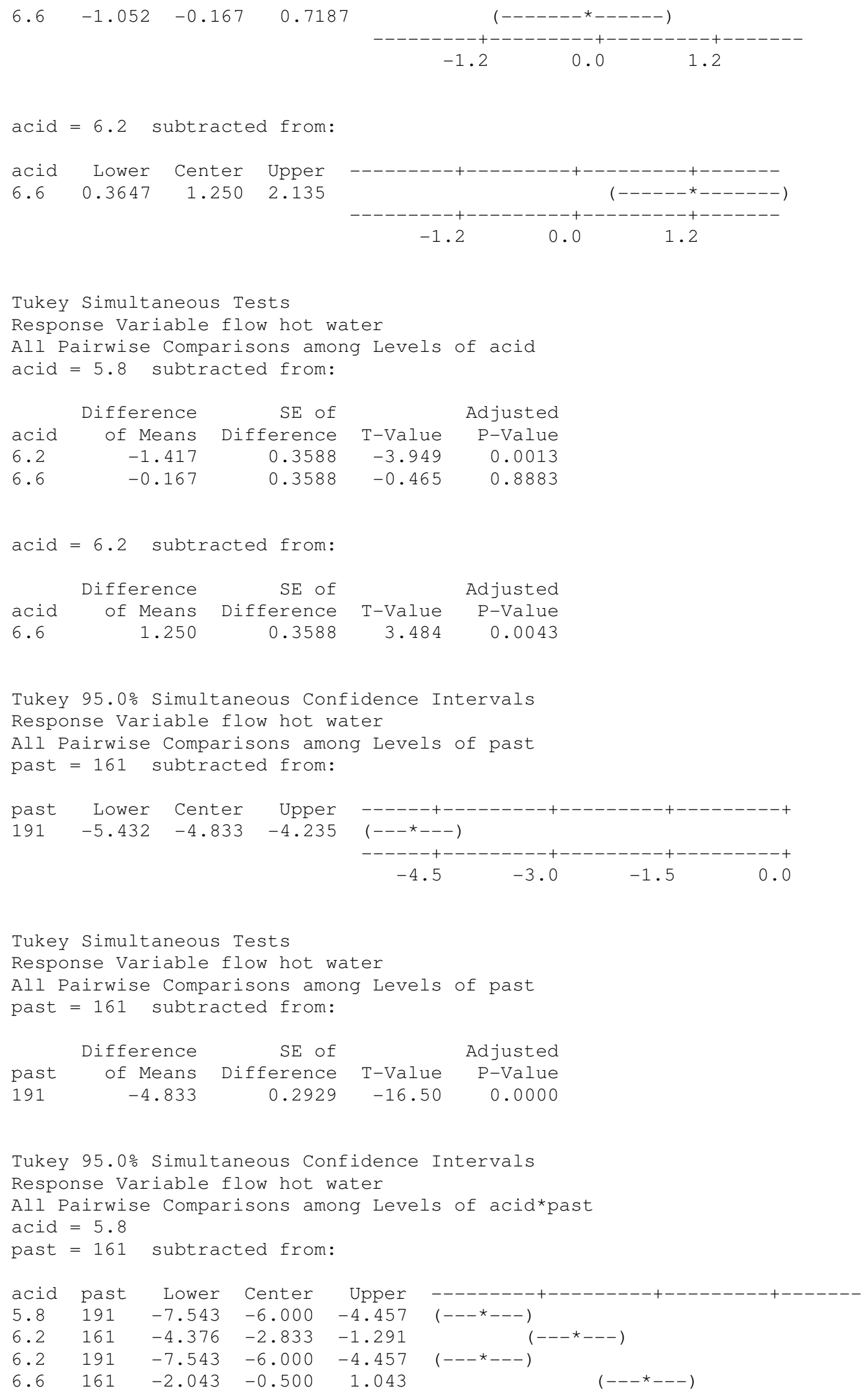


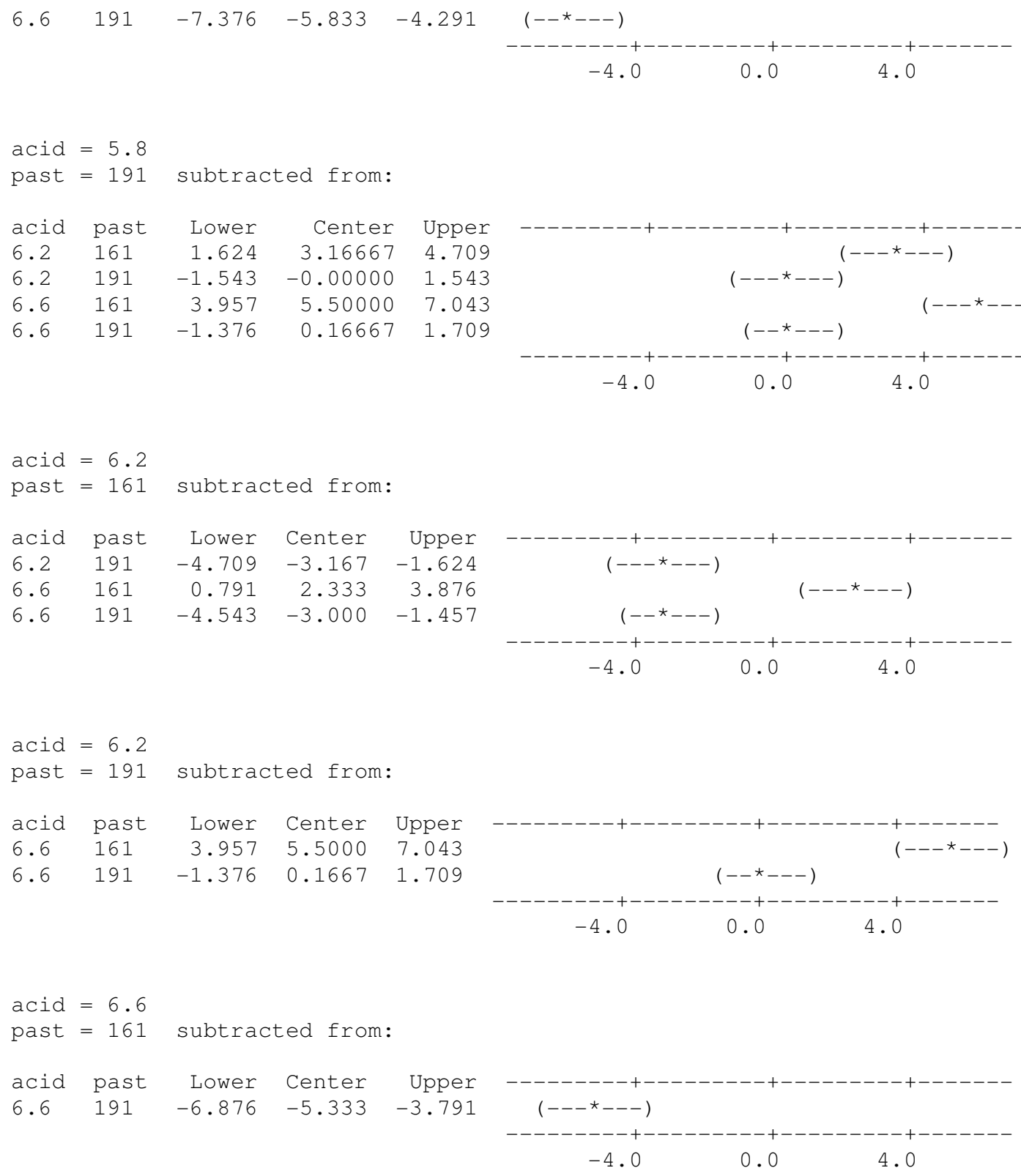

$\begin{array}{ccc}---------+--------+ & & ------- \\ -4.0 & 0.0 & 4.0\end{array}$

Tukey Simultaneous Tests Response Variable flow hot water All Pairwise Comparisons among Levels of acid*past acid $=5.8$ past $=161$ subtracted from:

$\begin{array}{llrrrr} & & \text { Difference } & \text { SE of } & \text { Adjusted } \\ \text { acid } & \text { past } & \text { of Means } & \text { Difference } & \text { T-Value } & \text { P-Value } \\ 5.8 & 191 & -6.000 & 0.5074 & -11.83 & 0.0000 \\ 6.2 & 161 & -2.833 & 0.5074 & -5.58 & 0.0001 \\ 6.2 & 191 & -6.000 & 0.5074 & -11.83 & 0.0000 \\ 6.6 & 161 & -0.500 & 0.5074 & -0.99 & 0.9190 \\ 6.6 & 191 & -5.833 & 0.5074 & -11.50 & 0.0000\end{array}$

acid $=5.8$ 


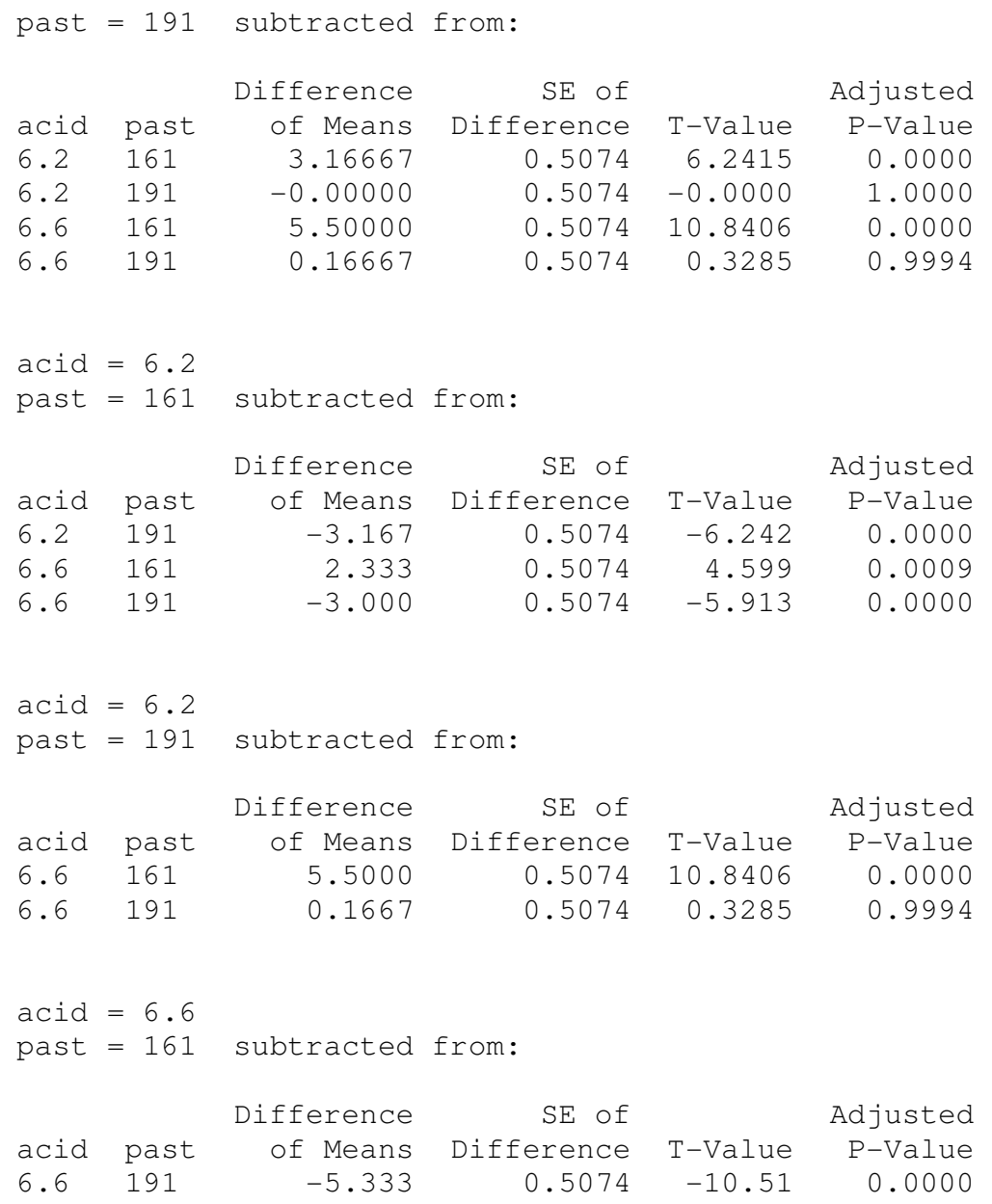

\subsection{General Linear Model for mean hardness, mean cohesiveness, mean springiness, mean gumminess and mean chewiness}

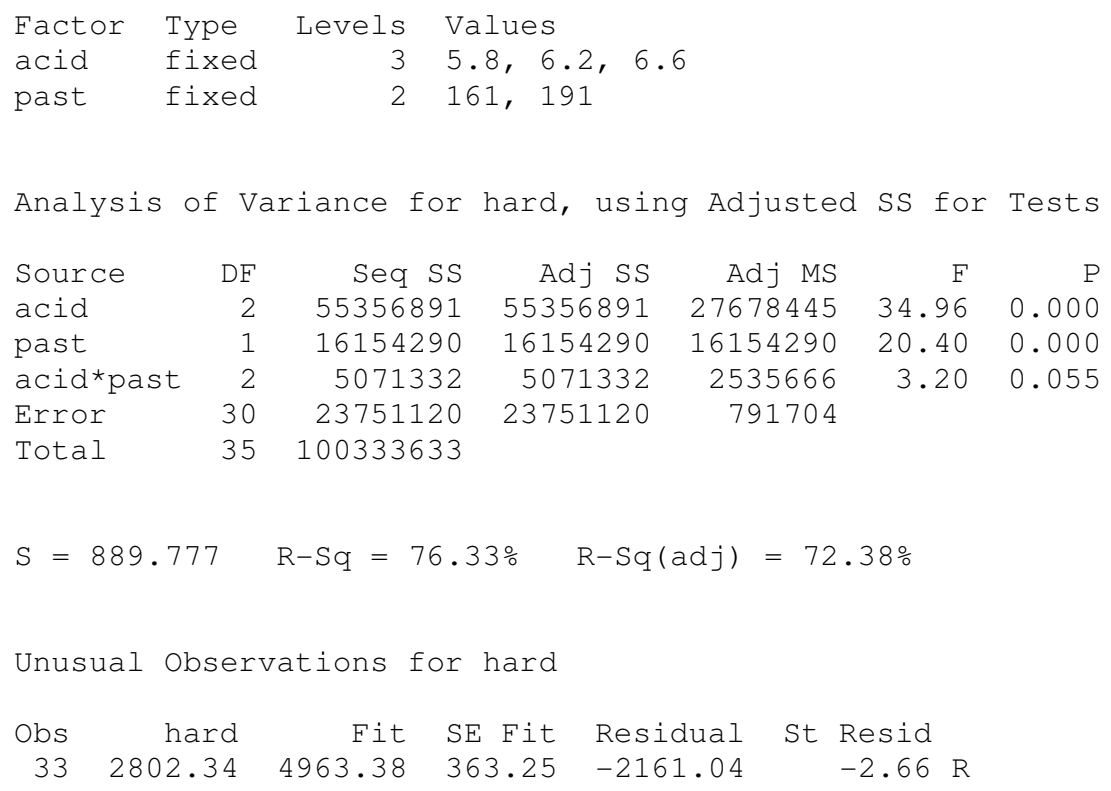


$\mathrm{R}$ denotes an observation with a large standardized residual.

\begin{tabular}{|c|c|c|c|c|c|c|c|}
\hline \multicolumn{2}{|c|}{ Source } & $\mathrm{DF}$ & Seq SS & Adj $S S$ & Adj $M S$ & $\mathrm{~F}$ & \\
\hline \multicolumn{2}{|c|}{ acid } & 2 & 0.009456 & 0.009456 & 0.004728 & 0.61 & 0.550 \\
\hline \multicolumn{2}{|c|}{ past } & 1 & 0.047742 & 0.047742 & 0.047742 & 6.16 & \\
\hline \multicolumn{2}{|c|}{ acid*past } & 2 & 0.056092 & 0.056092 & 0.028046 & 3.62 & 0. \\
\hline \multicolumn{2}{|c|}{ Error } & 30 & 0.232494 & 0.232494 & 0.007750 & & \\
\hline \multicolumn{2}{|c|}{ Total } & 35 & 0.345785 & & & & \\
\hline \multicolumn{3}{|c|}{$S=0.0880329$} & \multicolumn{2}{|c|}{$\mathrm{R}-\mathrm{Sq}=32.76 \%$} & \multicolumn{3}{|c|}{$R-S q(\operatorname{adj})=21.56 \%$} \\
\hline \multicolumn{4}{|c|}{ Unusual Observations for } & cohes & & & \\
\hline Obs & & hes & Fit & SE Fit & Residual & St & Resid \\
\hline 10 & 0.459 & 019 & 0.666006 & 0.035939 & -0.206987 & & -2.58 \\
\hline 17 & 0.800 & 263 & 0.594185 & 0.035939 & 0.206078 & & 2.56 \\
\hline 35 & 0.426 & & 0.594185 & 0.035939 & -0.168067 & & -2.09 \\
\hline
\end{tabular}

$\mathrm{R}$ denotes an observation with a large standardized residual.

Analysis of Variance for spring, using Adjusted SS for Tests

$\begin{array}{lrrrrrr}\text { Source } & \text { DF } & \text { Seq SS } & \text { Adj SS } & \text { Adj MS } & F & P \\ \text { acid } & 2 & 10.308 & 10.308 & 5.154 & 2.93 & 0.069 \\ \text { past } & 1 & 2.666 & 2.666 & 2.666 & 1.52 & 0.228 \\ \text { acid*past } & 2 & 1.010 & 1.010 & 0.505 & 0.29 & 0.752 \\ \text { Error } & 30 & 52.730 & 52.730 & 1.758 & & \\ \text { Total } & 35 & 66.715 & & & & \end{array}$

$S=1.32577 \quad R-S q=20.96 \% \quad R-S q(\operatorname{adj})=7.79 \%$

Unusual Observations for spring

Obs spring Fit SE Fit Residual St Resid

R denotes an observation with a large standardized residual.

Analysis of Variance for gum, using Adjusted SS for Tests

$\begin{array}{lrrrrrr}\text { Source } & \text { DF } & \text { Seq SS } & \text { Adj SS } & \text { Adj MS } & \text { F } & P \\ \text { acid } & 2 & 3449725 & 3449725 & 1724862 & 4.40 & 0.021 \\ \text { past } & 1 & 2058584 & 2058584 & 2058584 & 5.25 & 0.029 \\ \text { acid*past } & 2 & 5756189 & 5756189 & 2878095 & 7.34 & 0.003 \\ \text { Error } & 30 & 11764303 & 11764303 & 392143 & & \\ \text { Total } & 35 & 23028801 & & & & \end{array}$

$S=626.214 \quad R-S q=48.91 \% \quad R-S q(\operatorname{adj})=40.40 \%$

Unusual Observations for gum 


$\begin{array}{rrrrrr}\text { Obs } & \text { gum } & \text { Fit } & \text { SE Fit } & \text { Residual } & \text { St Resid } \\ 3 & 3046.85 & 1849.80 & 255.65 & 1197.06 & 2.09 \text { R } \\ 35 & 1266.10 & 2434.62 & 255.65 & -1168.52 & -2.04 \text { R }\end{array}$

$\mathrm{R}$ denotes an observation with a large standardized residual.

Analysis of Variance for chew, using Adjusted SS for Tests

$\begin{array}{lrrrrrr}\text { Source } & \text { DF } & \text { Seq SS } & \text { Adj SS } & \text { Adj MS } & F & P \\ \text { acid } & 2 & 165671773 & 165671773 & 82835886 & 11.15 & 0.000 \\ \text { past } & 1 & 1097159 & 1097159 & 1097159 & 0.15 & 0.703 \\ \text { acid*past } & 2 & 23122225 & 23122225 & 11561113 & 1.56 & 0.227 \\ \text { Error } & 30 & 222844207 & 222844207 & 7428140 & & \\ \text { Total } & 35 & 412735365 & & & & \\ & \\ S=2725.46 & R-S q=46.01 \% & R-S q(\text { adj })=37.01 \% & \end{array}$

Unusual Observations for chew

$\begin{array}{rrrrrr}\text { Obs } & \text { chew } & \text { Fit } & \text { SE Fit } & \text { Residual } & \text { St Resid } \\ 3 & 11962.3 & 5712.1 & 1112.7 & 6250.2 & 2.51 \mathrm{R} \\ 15 & 2805.6 & 7830.4 & 1112.7 & -5024.8 & -2.02 \mathrm{R} \\ 32 & 15572.5 & 7830.4 & 1112.7 & 7742.0 & 3.11 \mathrm{R}\end{array}$

$\mathrm{R}$ denotes an observation with a large standardized residual.

Tukey 95.0\% Simultaneous Confidence Intervals

Response Variable hard

All Pairwise Comparisons among Levels of acid

acid $=5.8$ subtracted from:

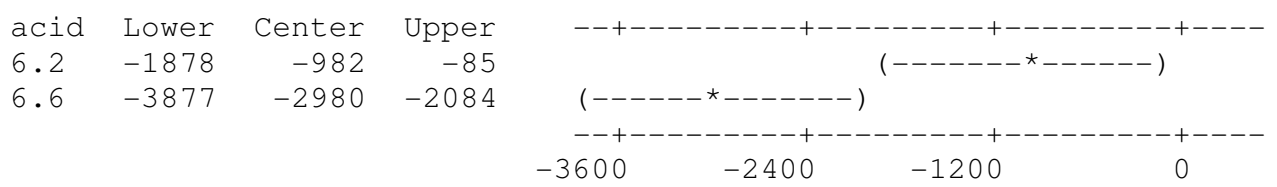

acid $=6.2$ subtracted from:

acid Lower Center Upper

$6.6-2895-1998-1102$

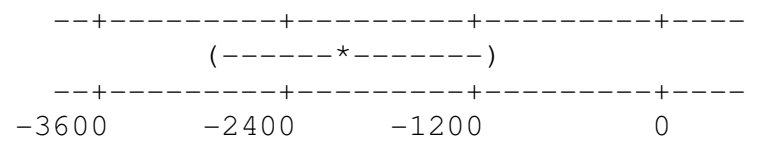

Tukey 95.0\% Simultaneous Confidence Intervals

Response Variable hard

All Pairwise Comparisons among Levels of past

past $=161$ subtracted from:

past Lower Center Upper

$191734.0 \quad 1340 \quad 1945$ (--------------- * -----------------$)$

$\begin{array}{ccc}-1050 & 1400 & 1750\end{array}$

Tukey 95.0\% Simultaneous Confidence Intervals

Response Variable hard 
All Pairwise Comparisons among Levels of acid*past

acid $=5.8$

past $=161$ subtracted from:

$\begin{array}{llrrr}\text { acid } & \text { past } & \text { Lower } & \text { Center } & \text { Upper } \\ 5.8 & 191 & -1125 & 437 & 1999 \\ 6.2 & 161 & -2979 & -1417 & 145 \\ 6.2 & 191 & -1672 & -110 & 1452 \\ 6.6 & 161 & -5461 & -3899 & -2337 \\ 6.6 & 191 & -3186 & -1624 & -62\end{array}$

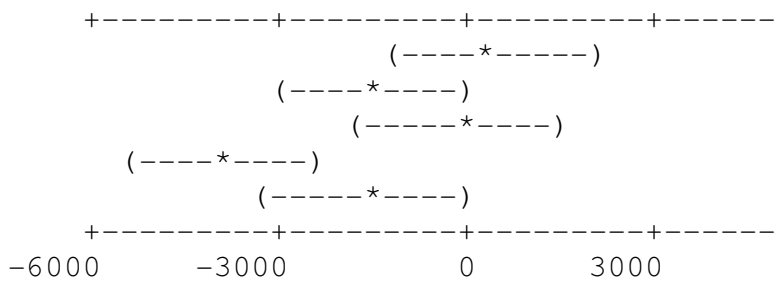

acid $=5.8$

past $=191$

subtracted from:

$\begin{array}{llrrr}\text { acid } & \text { past } & \text { Lower } & \text { Center } & \text { Upper } \\ 6.2 & 161 & -3416 & -1854 & -292 \\ 6.2 & 191 & -2109 & -547 & 1015 \\ 6.6 & 161 & -5898 & -4336 & -2774 \\ 6.6 & 191 & -3623 & -2061 & -499\end{array}$

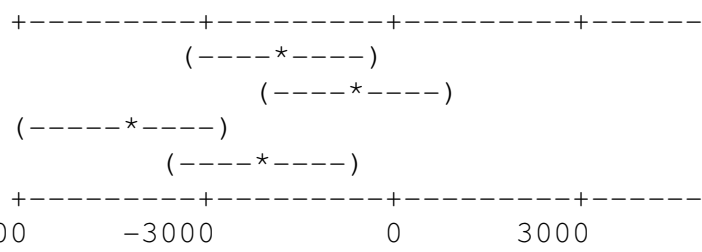

acid $=6.2$

past $=161$ subtracted from:

acid past Lower Center Upper

$\begin{array}{lllll}6.2 & 191 & -255 & 1307 & 2869.1\end{array}$

$\begin{array}{lllll}6.6 & 161 & -4044 & -2482 & -920.5\end{array}$

$\begin{array}{lllll}6.6 & 191 & -1769 & -207 & 1354.5\end{array}$

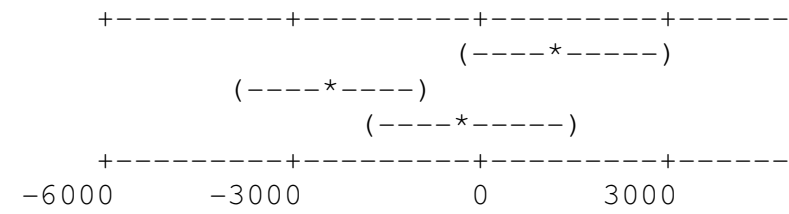

acid $=6.2$

past $=191$ subtracted from:

acid past Lower Center Upper

$\begin{array}{lllll}6.6 & 161 & -5352 & -3790 & -2228\end{array}$

$\begin{array}{lllll}6.6 & 191 & -3076 & -1515 & 47\end{array}$

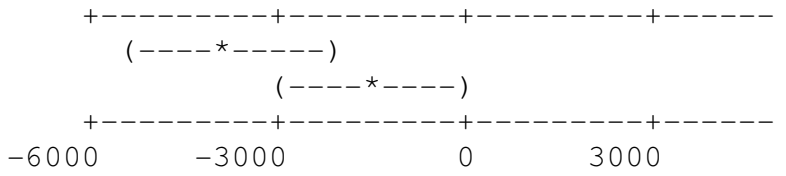

acid $=6.6$

past $=161$ subtracted from:

acid past Lower Center Upper

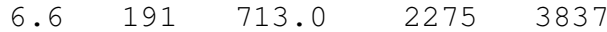

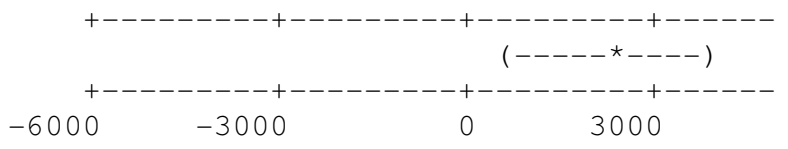

Tukey 95.0\% Simultaneous Confidence Intervals

Response Variable cohes

All Pairwise Comparisons among Levels of acid

acid $=5.8$ subtracted from:

acid Lower Center Upper

$\begin{array}{lllll}6.2 & -0.1013 & -0.01257 & 0.07613\end{array}$

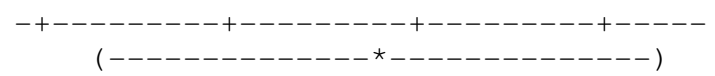



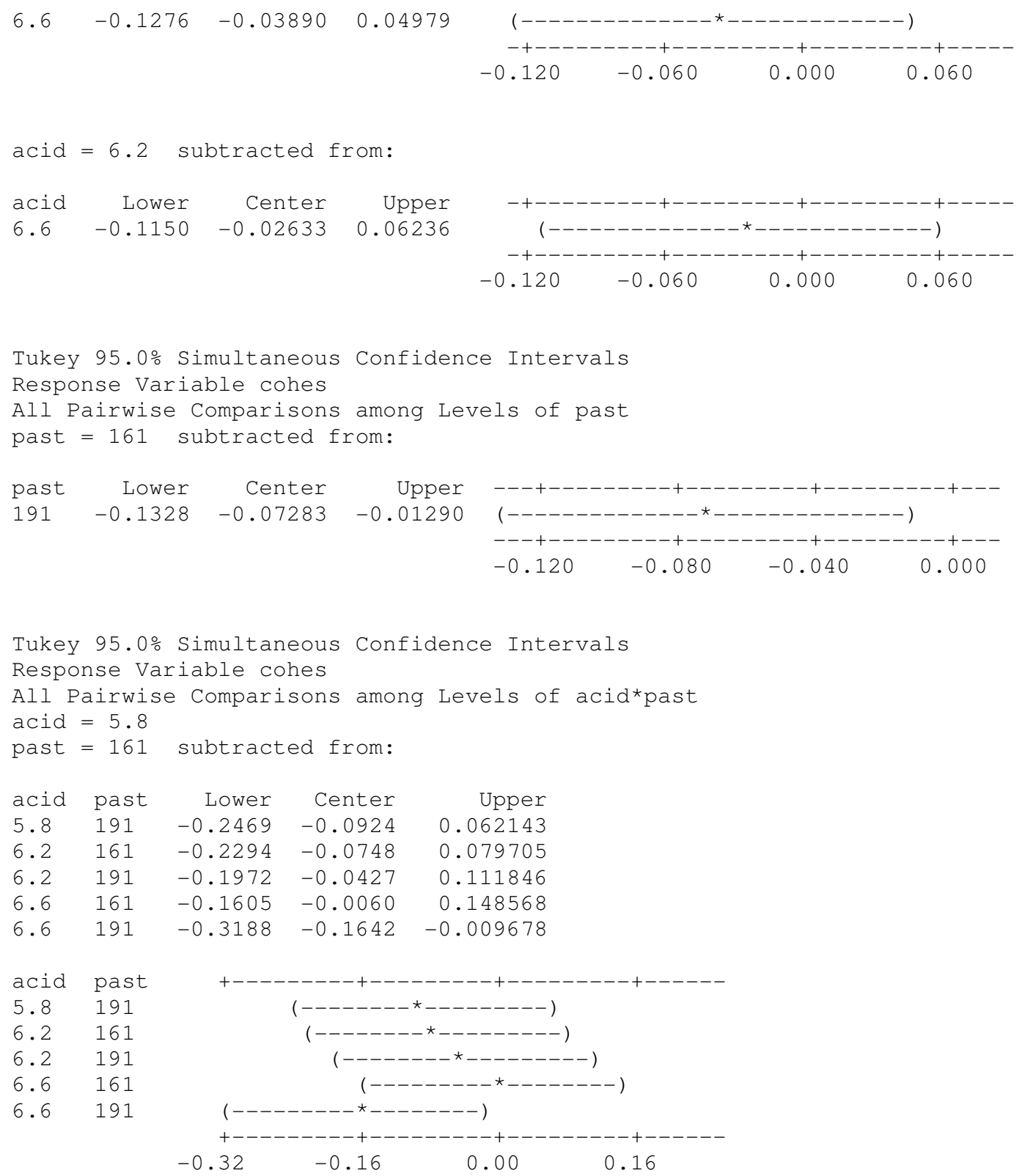

acid $=5.8$

past $=191$

$\begin{array}{llrrr}\text { acid } & \text { past } & \text { Lower } & \text { Center } & \text { Upper } \\ 6.2 & 161 & -0.1370 & 0.01756 & 0.17210 \\ 6.2 & 191 & -0.1048 & 0.04970 & 0.20424 \\ 6.6 & 161 & -0.0681 & 0.08642 & 0.24096 \\ 6.6 & 191 & -0.2264 & -0.07182 & 0.08272\end{array}$

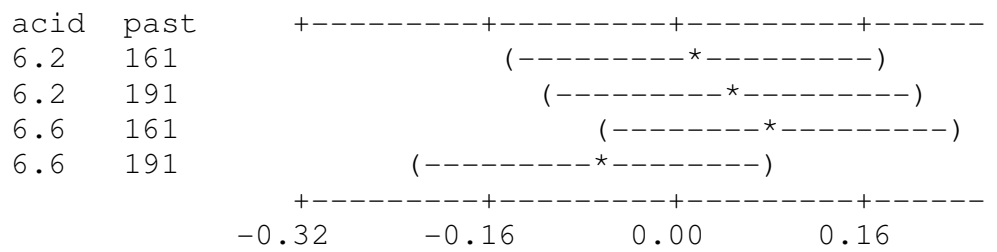




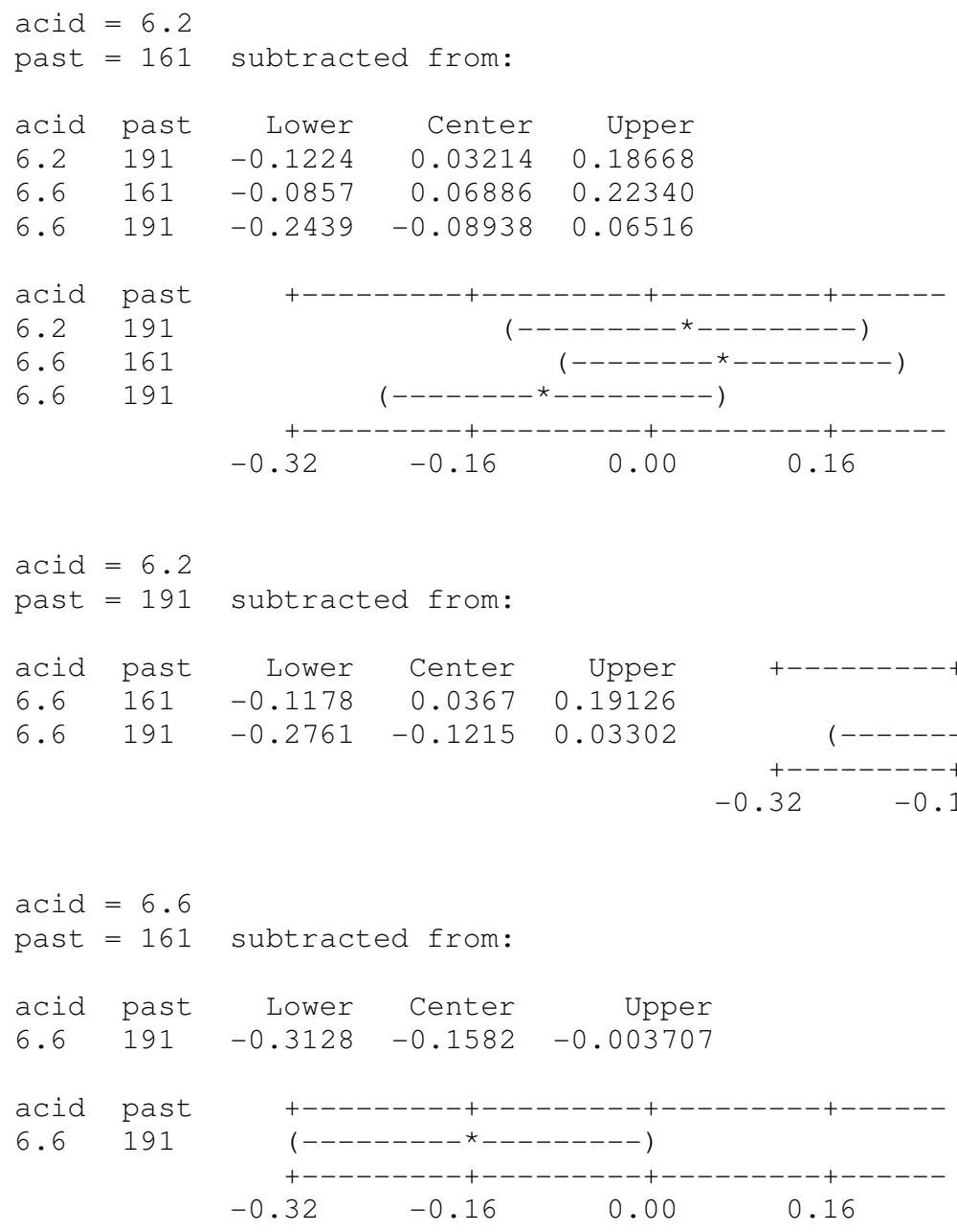

Tukey 95.0\% Simultaneous Confidence Intervals Response Variable spring

All Pairwise Comparisons among Levels of acid acid $=5.8$ subtracted from:

$\begin{array}{lrrr}\text { acid } & \text { Lower } & \text { Center } & \text { Upper } \\ 6.2 & -1.028 & 0.3078 & 1.6435 \\ 6.6 & -2.285 & -0.9495 & 0.3862\end{array}$

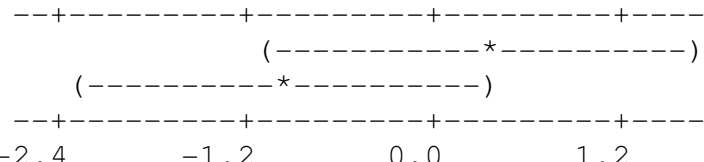

acid $=6.2$ subtracted from:

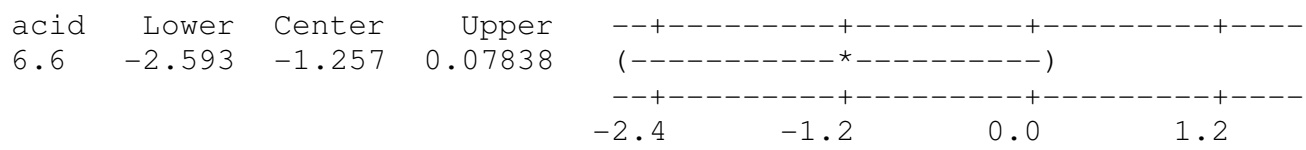

Tukey 95.0\% Simultaneous Confidence Intervals Response Variable spring

All Pairwise Comparisons among Levels of past 

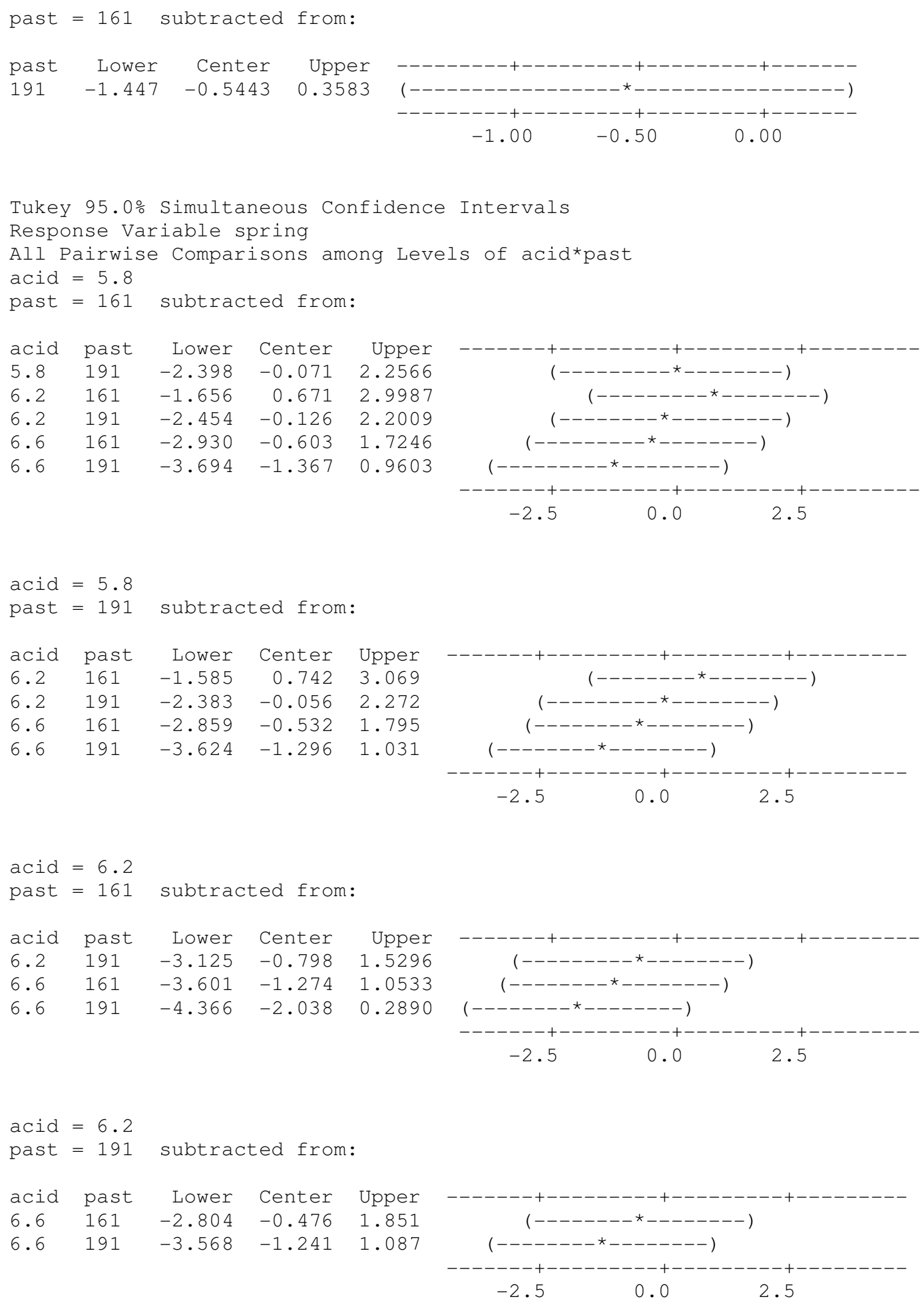
Tukey 95.0\% Simultaneous Confidence Intervals Response Variable gum

All Pairwise Comparisons among Levels of acid acid $=5.8$ subtracted from:

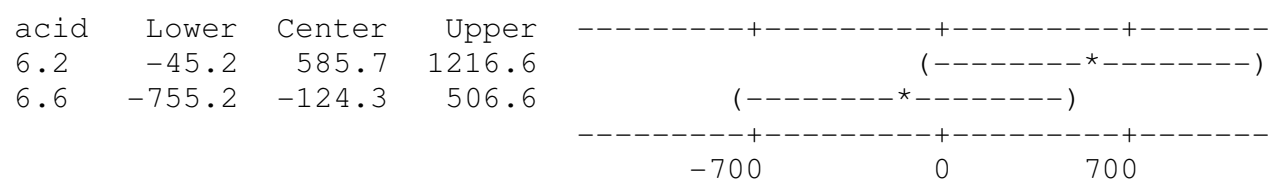

acid $=6.2$ subtracted from:

acid Lower Center Upper ---------+---------+---------+-------

$6.6-1341 \quad-709.9 \quad-79.03 \quad(--------\star--------)$

--------+--------+---------+-------
-700
0

$-700$

700

Tukey 95.0\% Simultaneous Confidence Intervals Response Variable gum

All Pairwise Comparisons among Levels of past past $=161$ subtracted from:

past Lower Center Upper

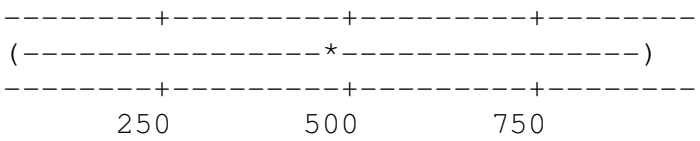

Tukey 95.0\% Simultaneous Confidence Intervals

Response Variable gum

All Pairwise Comparisons among Levels of acid*past

acid $=5.8$

past $=161$ subtracted from:

$\begin{array}{llrrr}\text { acid } & \text { past } & \text { Lower } & \text { Center } & \text { Upper } \\ 5.8 & 191 & -1284 & -185 & 914.24 \\ 6.2 & 161 & -614 & 485 & 1584.13 \\ 6.2 & 191 & -598 & 501 & 1600.72 \\ 6.6 & 161 & -2118 & -1018 & 80.88 \\ 6.6 & 191 & -514 & 585 & 1684.12\end{array}$

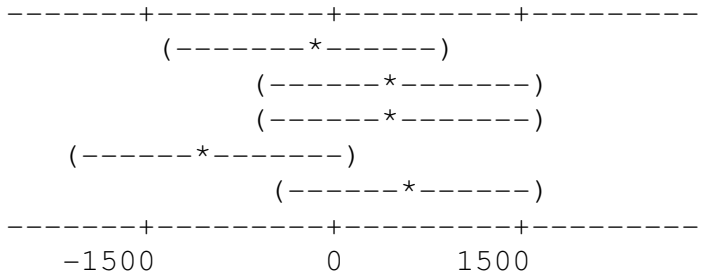

acid $=5.8$

past $=191$ subtracted from:

$\begin{array}{llrrr}\text { acid } & \text { past } & \text { Lower } & \text { Center } & \text { Upper } \\ 6.2 & 161 & -429 & 669.9 & 1769.2 \\ 6.2 & 191 & -413 & 686.5 & 1785.8 \\ 6.6 & 161 & -1933 & -833.4 & 265.9 \\ 6.6 & 191 & -329 & 769.9 & 1869.2\end{array}$

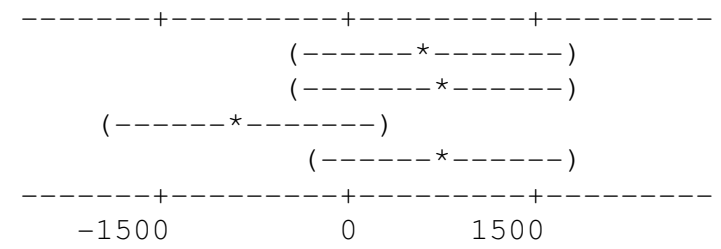

acid $=6.2$ 


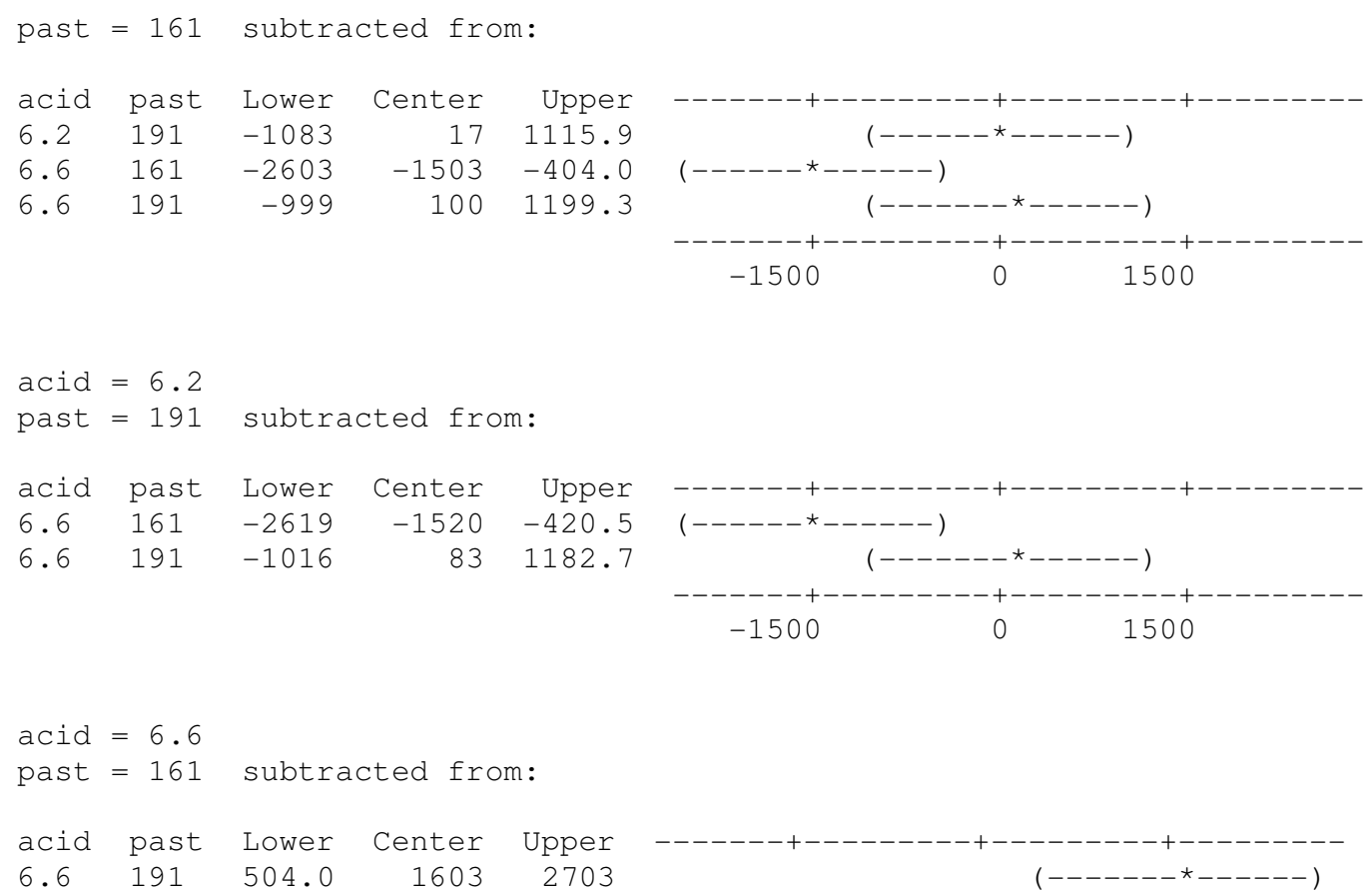

Tukey 95.0\% Simultaneous Confidence Intervals Response Variable chew

All Pairwise Comparisons among Levels of acid acid $=5.8$ subtracted from:

$\begin{array}{lrrr}\text { acid } & \text { Lower } & \text { Center } & \text { Upper } \\ 6.2 & 83 & 2828 & 5574.3 \\ 6.6 & -5167 & -2421 & 324.9\end{array}$

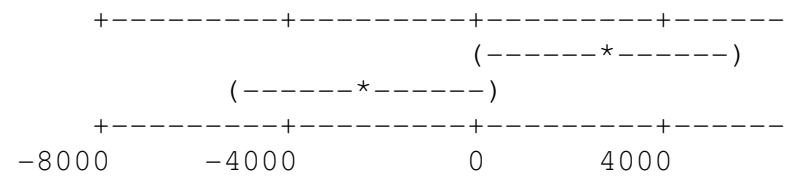

acid $=6.2$ subtracted from:

acid Lower Center Upper $6.6-7995 \quad-5249-2504$

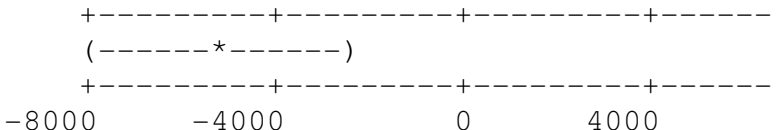

Tukey 95.0\% Simultaneous Confidence Intervals Response Variable chew All Pairwise Comparisons among Levels of past past $=161$ subtracted from:

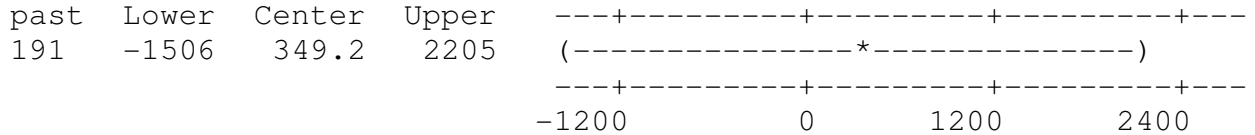

Tukey 95.0\% Simultaneous Confidence Intervals Response Variable chew

All Pairwise Comparisons among Levels of acid*past 


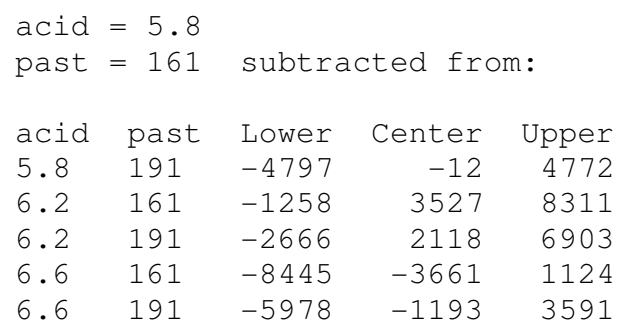

acid $=6.2$

past $=161$

past Lower Center Upper

$\begin{array}{llll}191 & -6193 & -1408 & 3376\end{array}$

$\begin{array}{lllll}6.6 & 161 & -11972 & -7187 & -2403\end{array}$

$\begin{array}{lllll}6.6 & 191 & -9504 & -4720 & 65\end{array}$

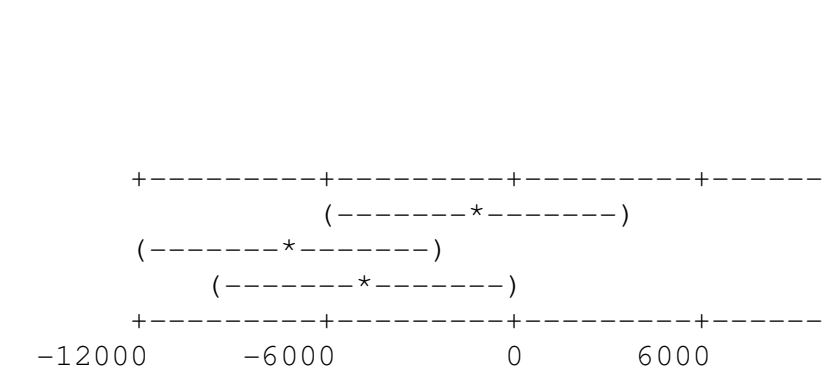

acid $=6.2$

past $=191$

$\begin{array}{llrrr}\text { acid } & \text { past } & \text { Lower } & \text { Center } & \text { Upper } \\ 6.6 & 161 & -10564 & -5779 & -994.7 \\ 6.6 & 191 & -8096 & -3311 & 1473.0\end{array}$

acid $=6.6$

past $=161$ subtracted from:

acid past Lower Center Upper

$\begin{array}{lllll}6.6 & 191 & -2317 & 2468 & 7252\end{array}$
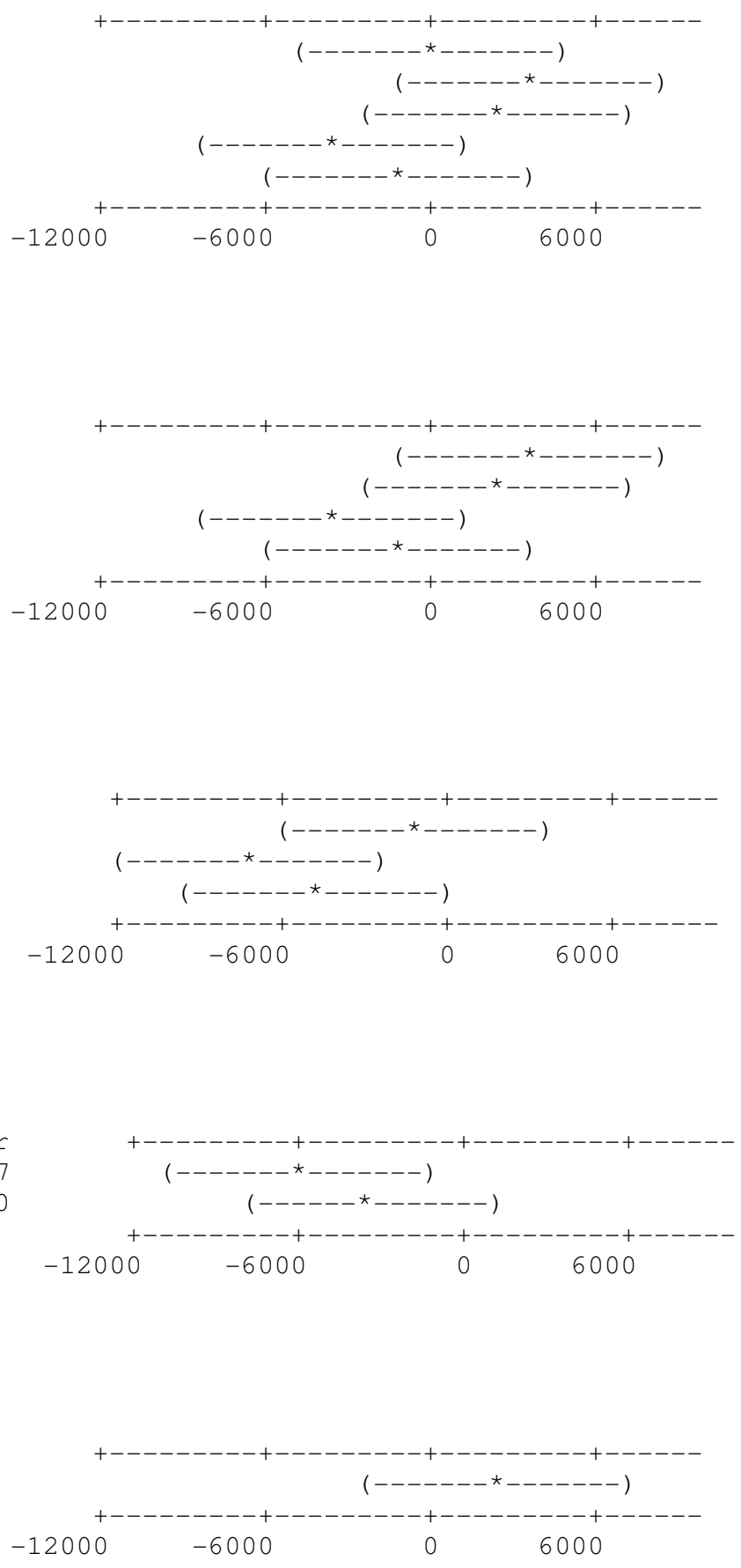


\section{Experimental design statistical analysis}

\subsection{General Linear Model for mean moisture, mean protein and mean fat}
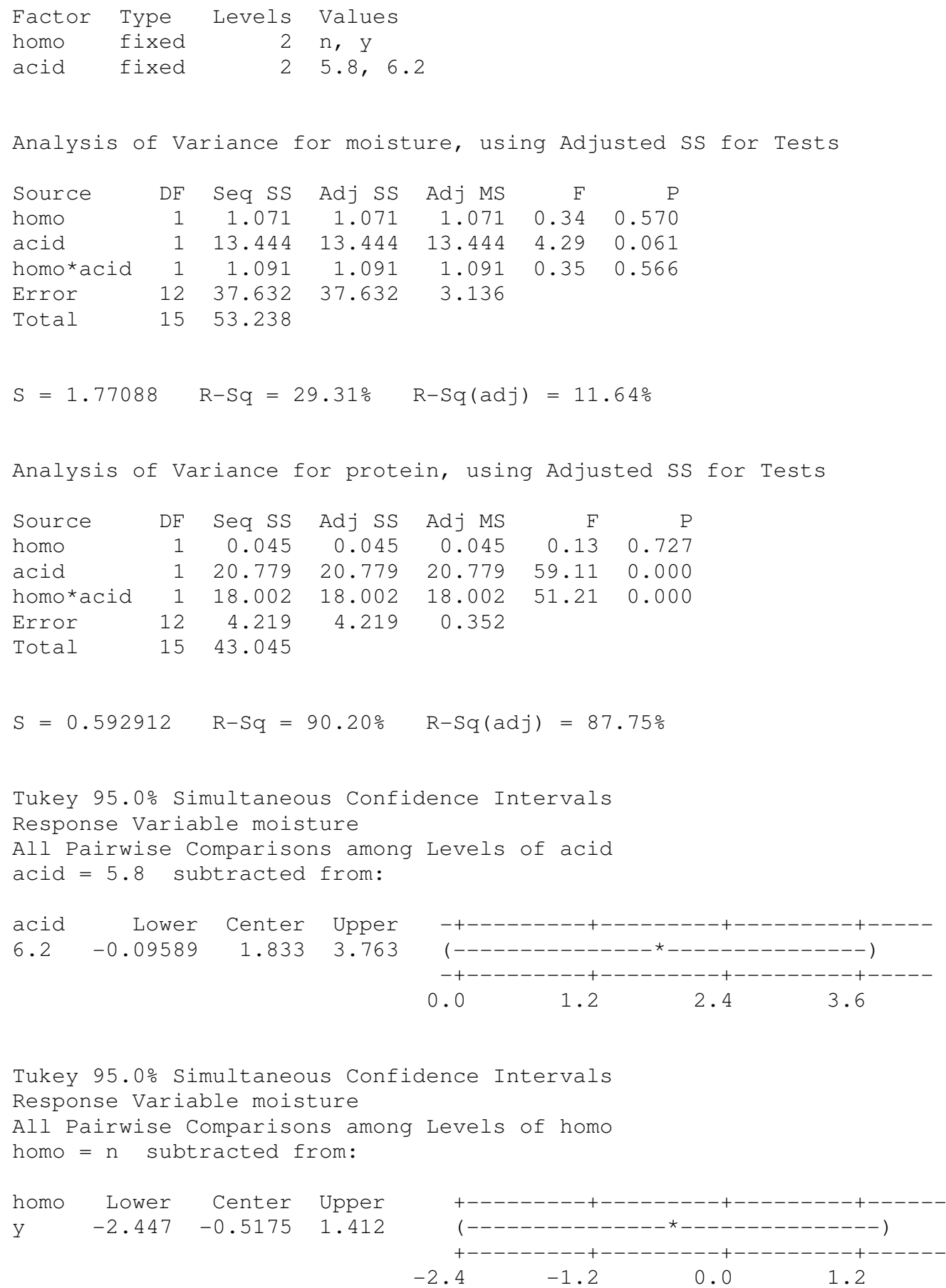

Tukey 95.0\% Simultaneous Confidence Intervals Response Variable moisture

All Pairwise Comparisons among Levels of homo*acid

homo $=\mathrm{n}$

acid $=5.8$ subtracted from: 


$\begin{array}{llrrr}\text { homo } & \text { acid } & \text { Lower } & \text { Center } & \text { Upper } \\ \mathrm{n} & 6.2 & -1.363 & 2.35563 & 6.074 \\ \mathrm{y} & 5.8 & -3.714 & 0.00486 & 3.724 \\ \mathrm{y} & 6.2 & -2.403 & 1.31586 & 5.035\end{array}$
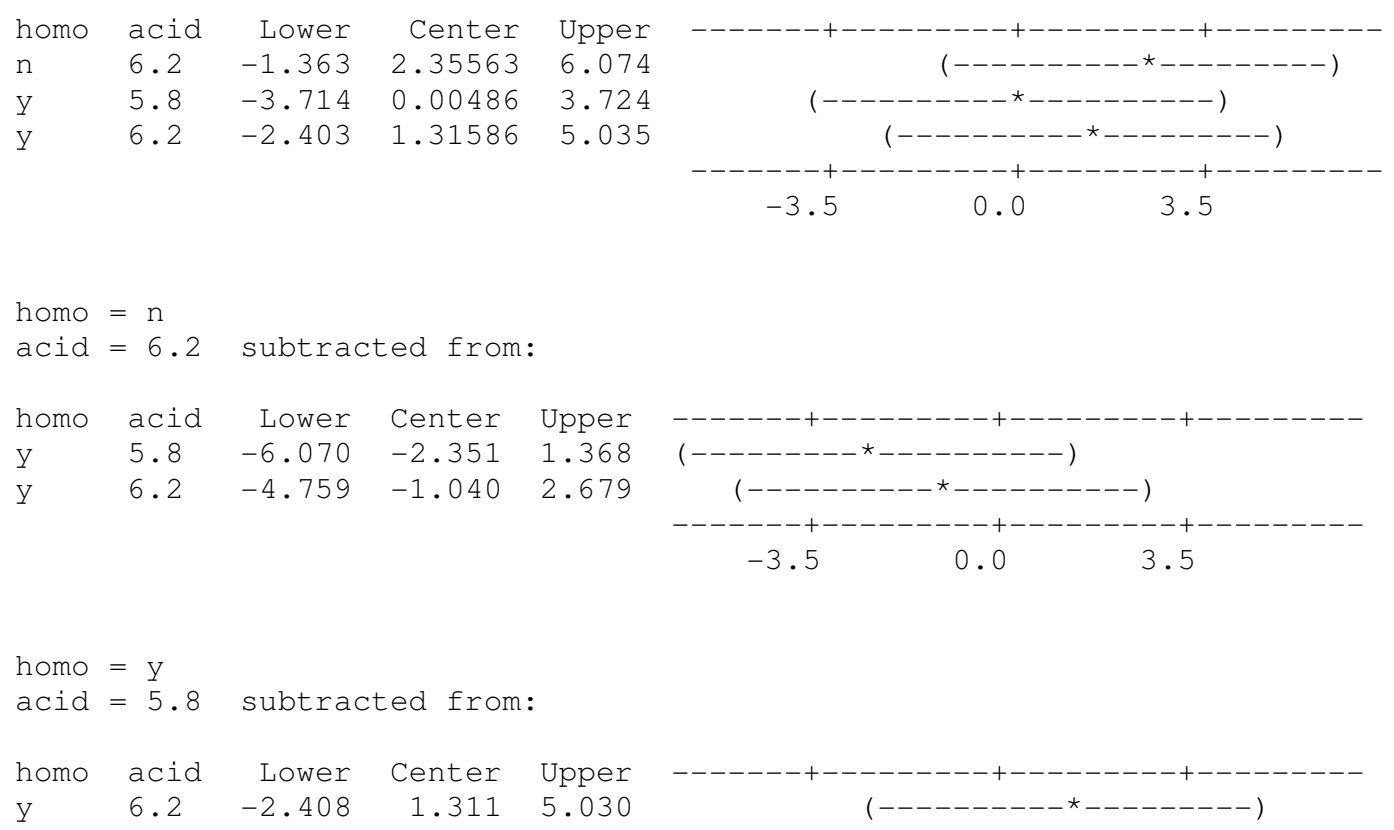

Tukey 95.0\% Simultaneous Confidence Intervals Response Variable protein

All Pairwise Comparisons among Levels of acid acid $=5.8$ subtracted from:

acid Lower Center Upper -------+--------+-------- +--------

$6.2-2.925-2.279-1.633(--------\star-------)$

$-2.40-1.60-0.80$

Tukey 95.0\% Simultaneous Confidence Intervals Response Variable protein All Pairwise Comparisons among Levels of homo homo $=\mathrm{n}$ subtracted from:

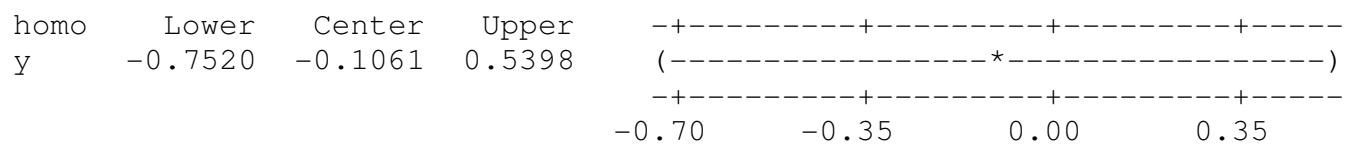

Tukey 95.0\% Simultaneous Confidence Intervals Response Variable protein All Pairwise Comparisons among Levels of homo*acid homo $=\mathrm{n}$ acid $=5.8$ subtracted from:

\begin{tabular}{|c|c|c|c|c|c|}
\hline homo & acid & Lower & Center & Upper & 1 \\
\hline$n$ & 6.2 & -5.646 & -4.401 & -3.156 & $(----\star----)$ \\
\hline 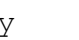 & 5.8 & -3.473 & -2.228 & -0.982 & $\left(----\star_{----}\right)$ \\
\hline & 6.2 & -3.630 & -2.385 & -1.140 & $(----\star----)$ \\
\hline & & & & & $\begin{array}{l}---+- \\
-2.5\end{array}$ \\
\hline
\end{tabular}




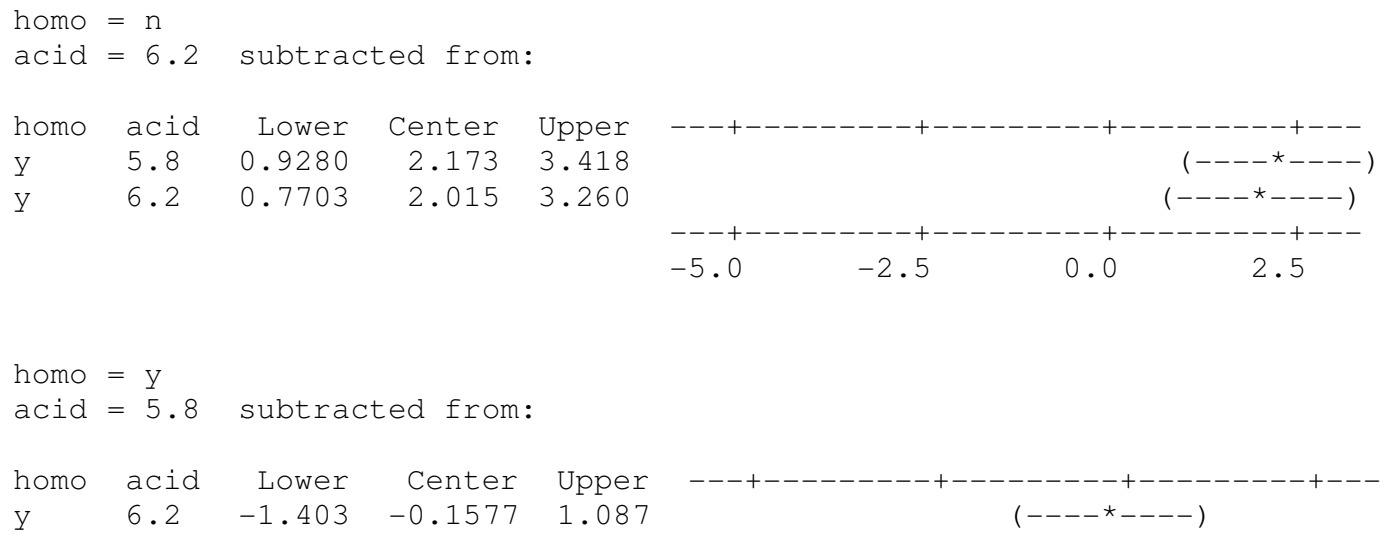

\section{General Linear Model: fat versus homo, acid}

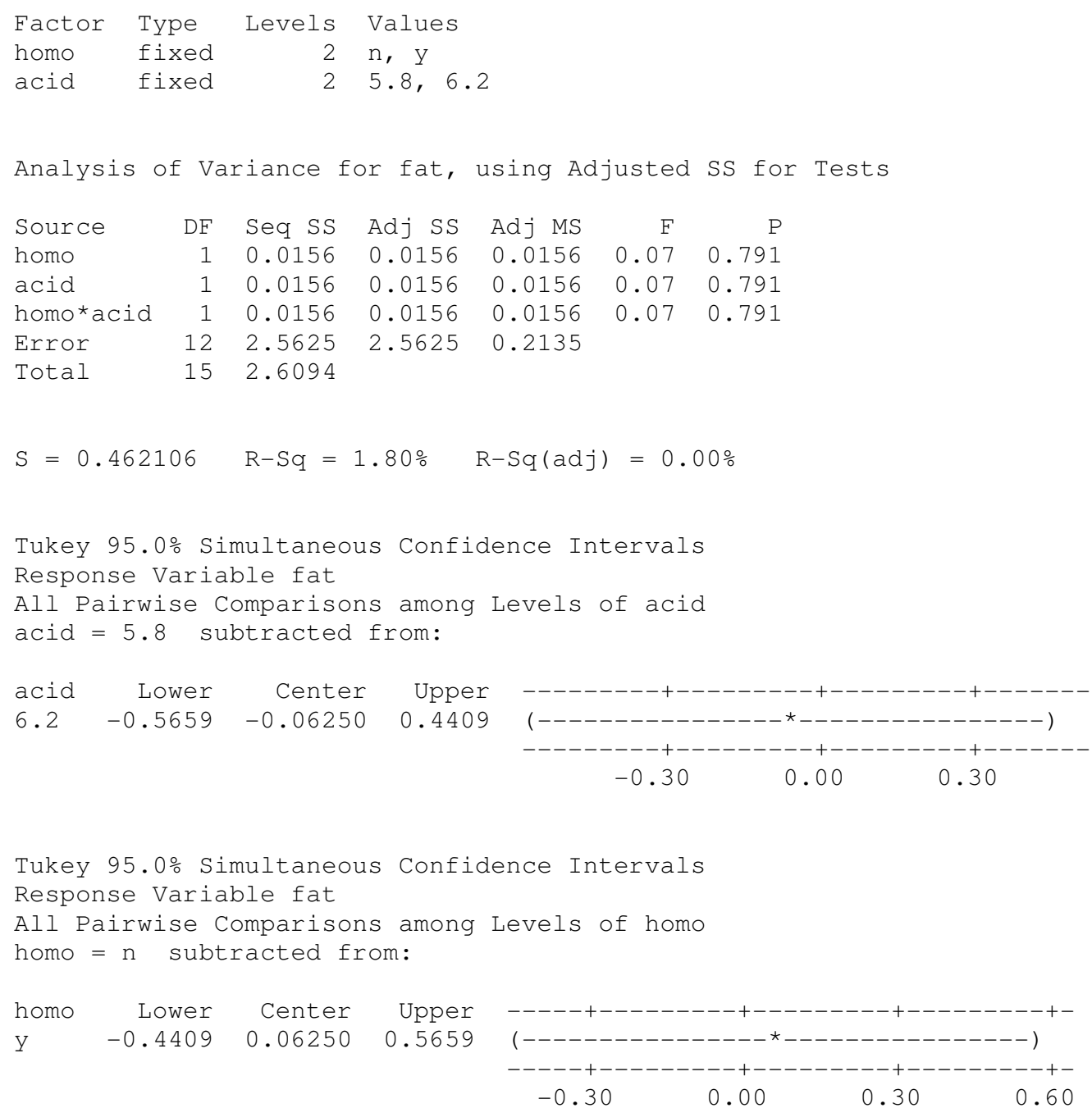




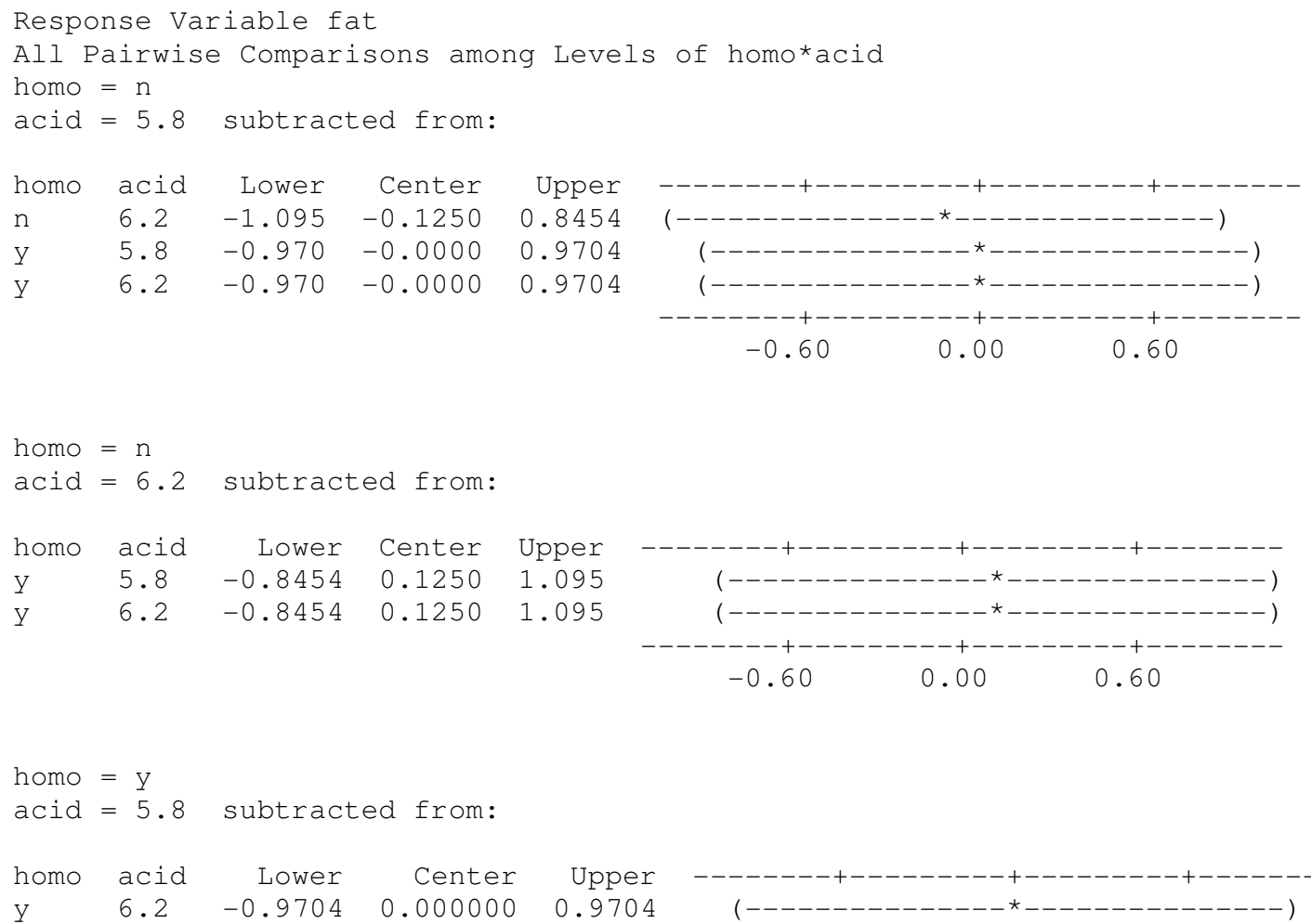

\subsection{General Linear Model for mean flow in oven, microwave and hot water:}

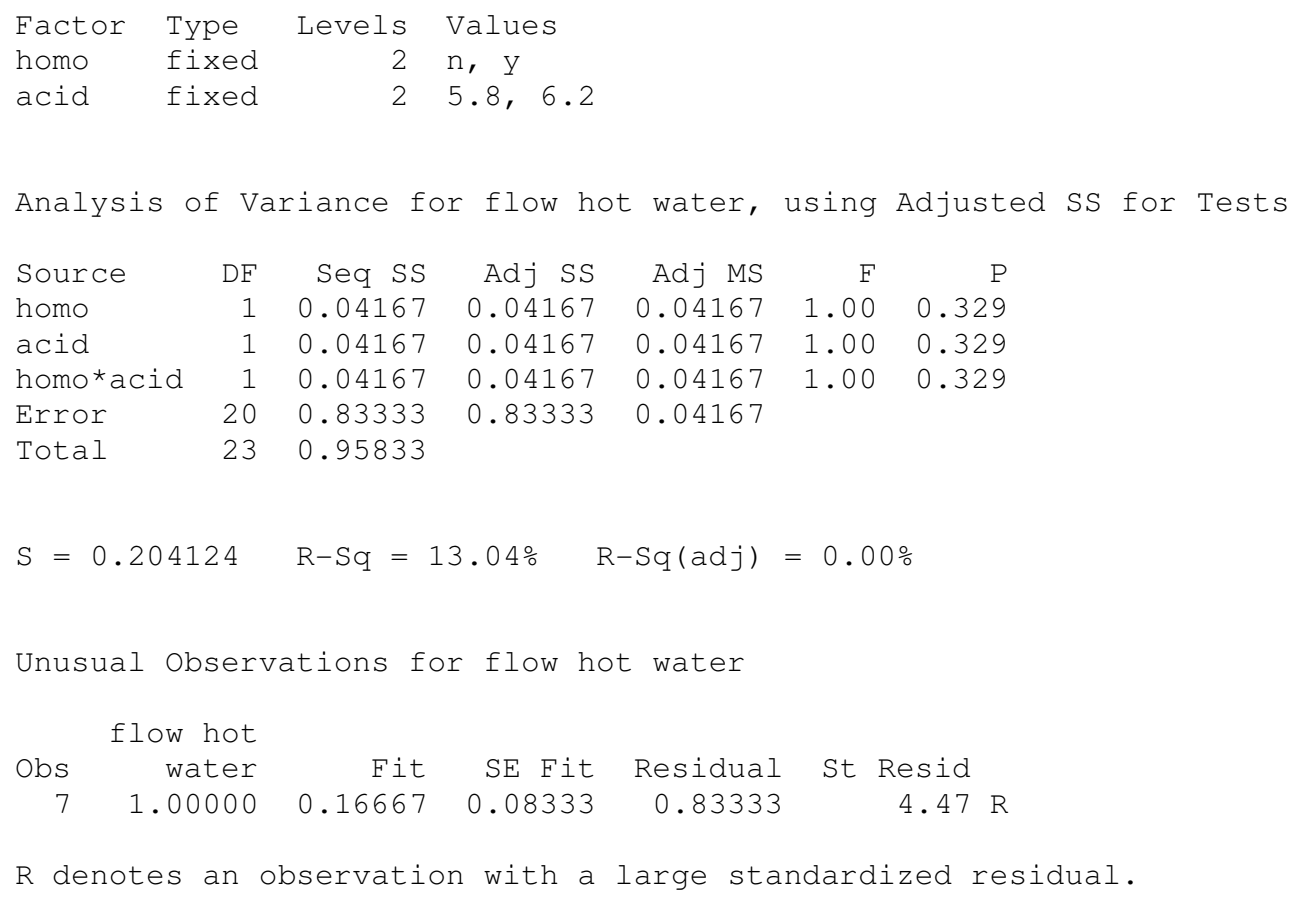


Analysis of Variance for flow microwave, using Adjusted SS for Tests

$\begin{array}{lrlllrr}\text { Source } & \text { DF } & \text { Seq SS } & \text { Adj SS } & \text { Adj MS } & F & P \\ \text { homo } & 1 & 0.0417 & 0.0417 & 0.0417 & 0.20 & 0.660 \\ \text { acid } & 1 & 1.0417 & 1.0417 & 1.0417 & 5.00 & 0.037 \\ \text { homo*acid } & 1 & 0.3750 & 0.3750 & 0.3750 & 1.80 & 0.195 \\ \text { Error } & 20 & 4.1667 & 4.1667 & 0.2083 & & \\ \text { Total } & 23 & 5.6250 & & & & \\ & & & & & \\ \text { S }=0.456435 & \text { R-Sq }=25.93 \% & R-S q(\operatorname{adj})=14.81 \%\end{array}$

Analysis of Variance for flow oven, using Adjusted ss for Tests

$\begin{array}{lrrrrrr}\text { Source } & \text { DF } & \text { Seq SS } & \text { Adj SS } & \text { Adj MS } & \text { F } & \text { P } \\ \text { homo } & 1 & 0.04167 & 0.04167 & 0.04167 & 1.00 & 0.329 \\ \text { acid } & 1 & 0.04167 & 0.04167 & 0.04167 & 1.00 & 0.329 \\ \text { homo*acid } & 1 & 0.04167 & 0.04167 & 0.04167 & 1.00 & 0.329 \\ \text { Error } & 20 & 0.83333 & 0.83333 & 0.04167 & & \\ \text { Total } & 23 & 0.95833 & & & & \\ \text { S }=0.204124 & \text { R-Sq }=13.04 \% & R-S q(\text { adj }) & =0.00 \%\end{array}$

Unusual Observations for flow oven

$\begin{array}{rrrrrr}\text { Obs flow oven } & \text { Fit } & \text { SE Fit } & \text { Residual } & \text { St Resid } \\ 7 & 1.00000 & 0.16667 & 0.08333 & 0.83333 & 4.47 \mathrm{R}\end{array}$

$\mathrm{R}$ denotes an observation with a large standardized residual.

Tukey 95.0\% Simultaneous Confidence Intervals Response Variable flow hot water

All Pairwise Comparisons among Levels of acid acid $=5.8$ subtracted from:

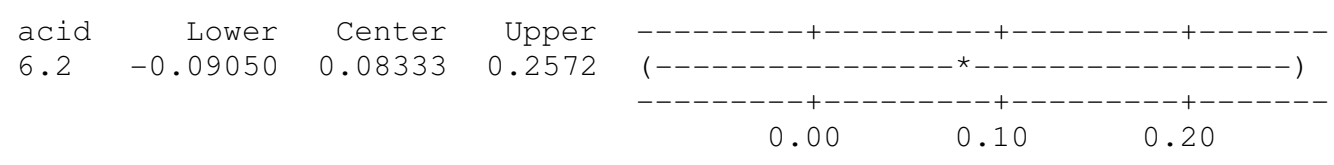

Tukey 95.0\% Simultaneous Confidence Intervals Response Variable flow hot water

All Pairwise Comparisons among Levels of homo homo $=n$ subtracted from:

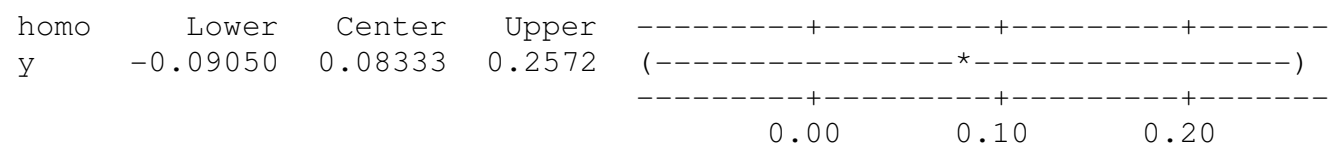

Tukey 95.0\% Simultaneous Confidence Intervals

Response Variable flow hot water

All Pairwise Comparisons among Levels of homo*acid

homo $=\mathrm{n}$

acid $=5.8$ subtracted from:

homo acid Lower Center Upper ---+---------+---------+---------+--- 


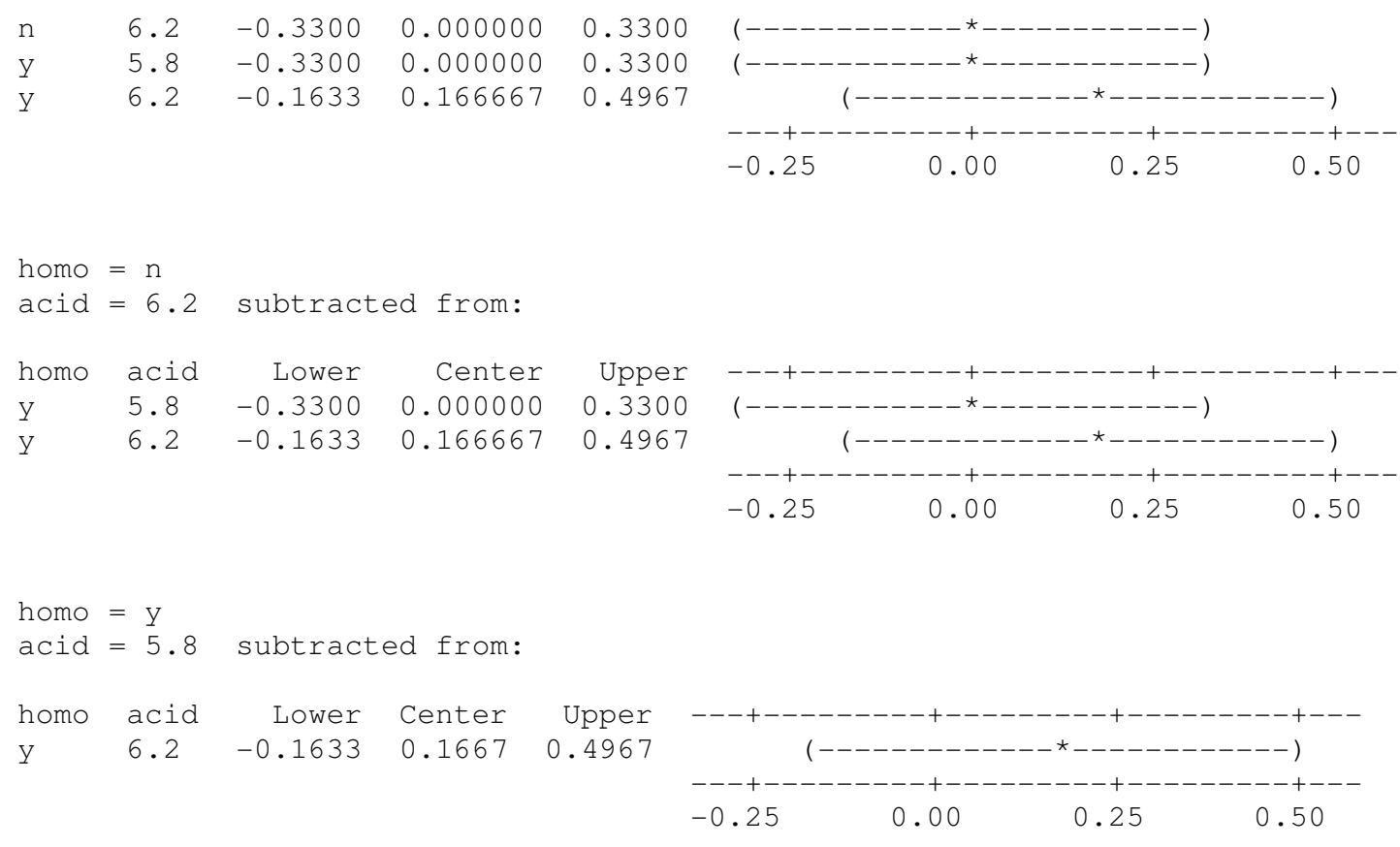

Tukey 95.0\% Simultaneous Confidence Intervals Response Variable flow microwave

All Pairwise Comparisons among Levels of acid acid $=5.8$ subtracted from:

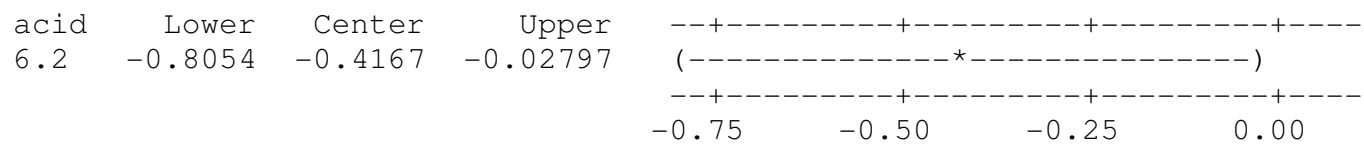

Tukey 95.0\% Simultaneous Confidence Intervals Response Variable flow microwave

All Pairwise Comparisons among Levels of homo homo $=\mathrm{n}$ subtracted from:

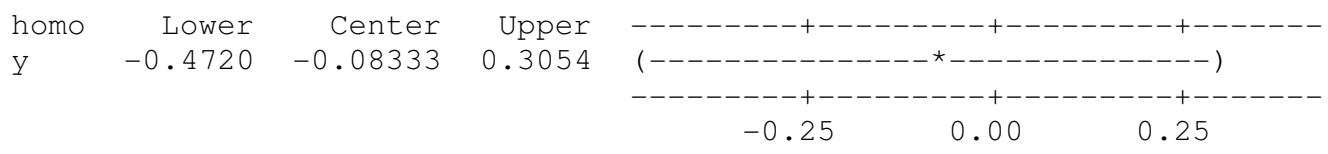

Tukey 95.0\% Simultaneous Confidence Intervals Response Variable flow microwave

All Pairwise Comparisons among Levels of homo*acid

homo $=\mathrm{n}$

acid $=5.8$ subtracted from:

$\begin{array}{llrrr}\text { homo } & \text { acid } & \text { Lower } & \text { Center } & \text { Upper } \\ \mathrm{n} & 6.2 & -1.405 & -0.6667 & 0.07124 \\ \mathrm{y} & 5.8 & -1.071 & -0.3333 & 0.40457 \\ \mathrm{y} & 6.2 & -1.238 & -0.5000 & 0.23790\end{array}$

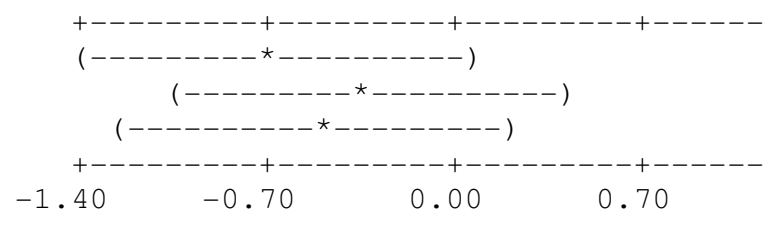



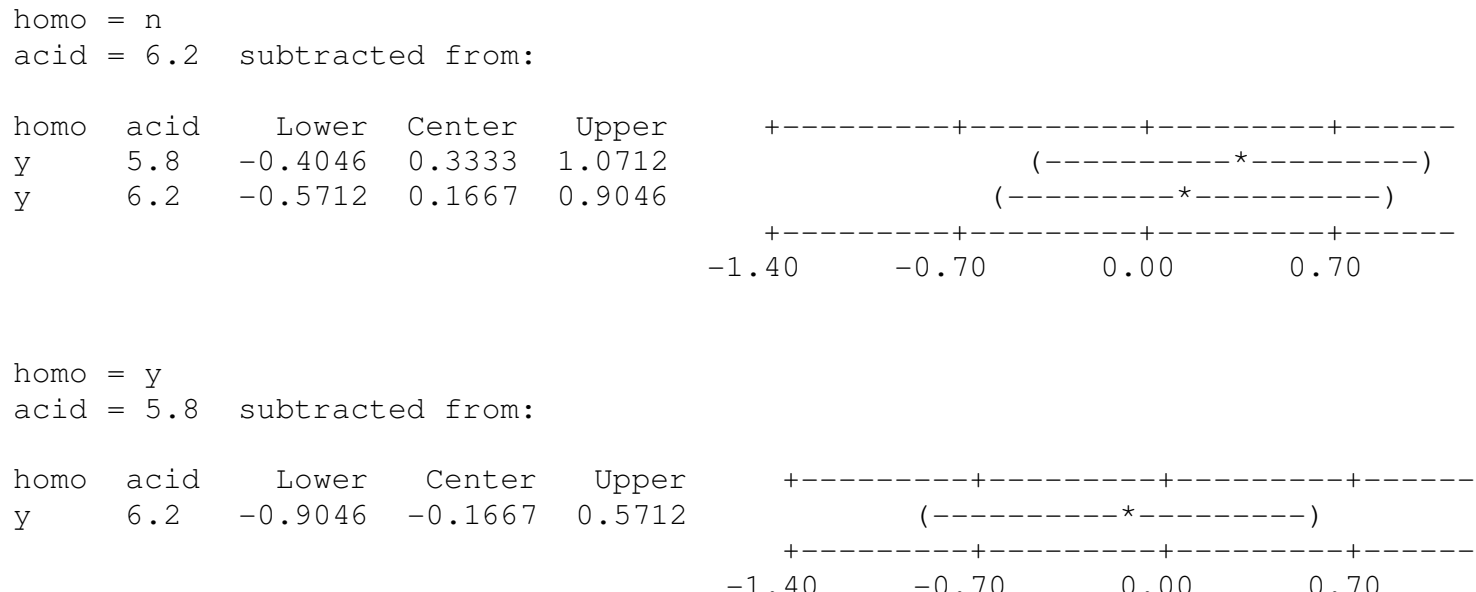

Tukey 95.0\% Simultaneous Confidence Intervals Response Variable flow oven

All Pairwise Comparisons among Levels of acid acid $=5.8$ subtracted from:

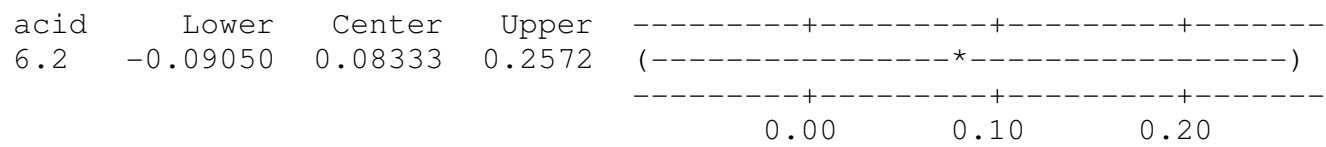

Tukey 95.0\% Simultaneous Confidence Intervals Response Variable flow oven

All Pairwise Comparisons among Levels of homo homo $=\mathrm{n}$ subtracted from:

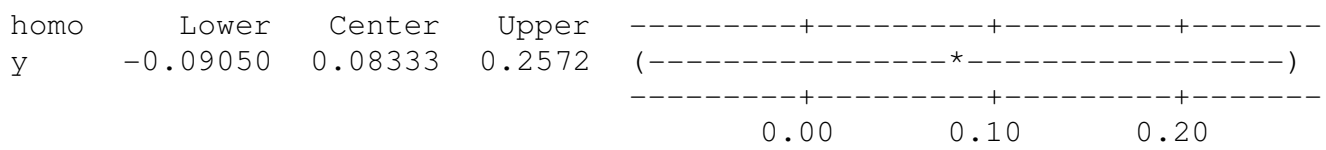

Tukey 95.0\% Simultaneous Confidence Intervals

Response Variable flow oven

All Pairwise Comparisons among Levels of homo*acid

homo $=\mathrm{n}$

acid $=5.8$ subtracted from:

homo acid Lower Center

$\begin{array}{llll}\mathrm{n} & 6.2 & -0.3300 & 0.000000\end{array}$

Upper

0.3300

$---+---------+---------+---------+---$

$\mathrm{y} \quad 5.8 \quad-0.3300 \quad 0.000000 \quad 0.3300$

$\begin{array}{lllll}\mathrm{y} & 6.2 & -0.1633 & 0.166667 & 0.4967\end{array}$

$(------------\star *------------)$

$(------------*------------)$
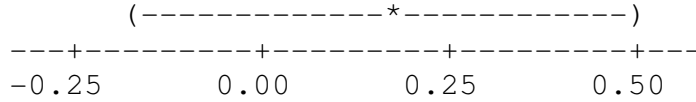

homo $=\mathrm{n}$

acid $=6.2$ subtracted from:

homo acid Lower Center Upper

$\begin{array}{lllll}\text { y } & 5.8 & -0.3300 & 0.000000 & 0.3300\end{array}$

$\begin{array}{lllll}\mathrm{y} & 6.2 & -0.1633 & 0.166667 & 0.4967\end{array}$

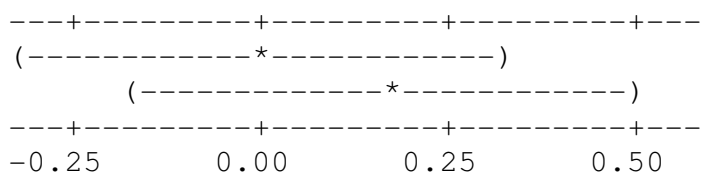




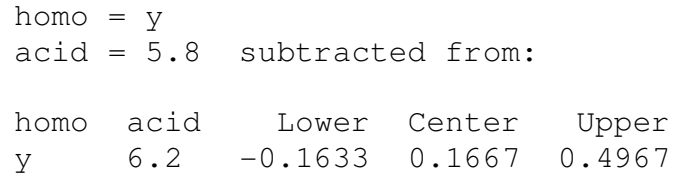

\subsection{General Linear Model for mean hardness, mean cohesiveness, mean springiness, mean gumminess and mean chewiness}

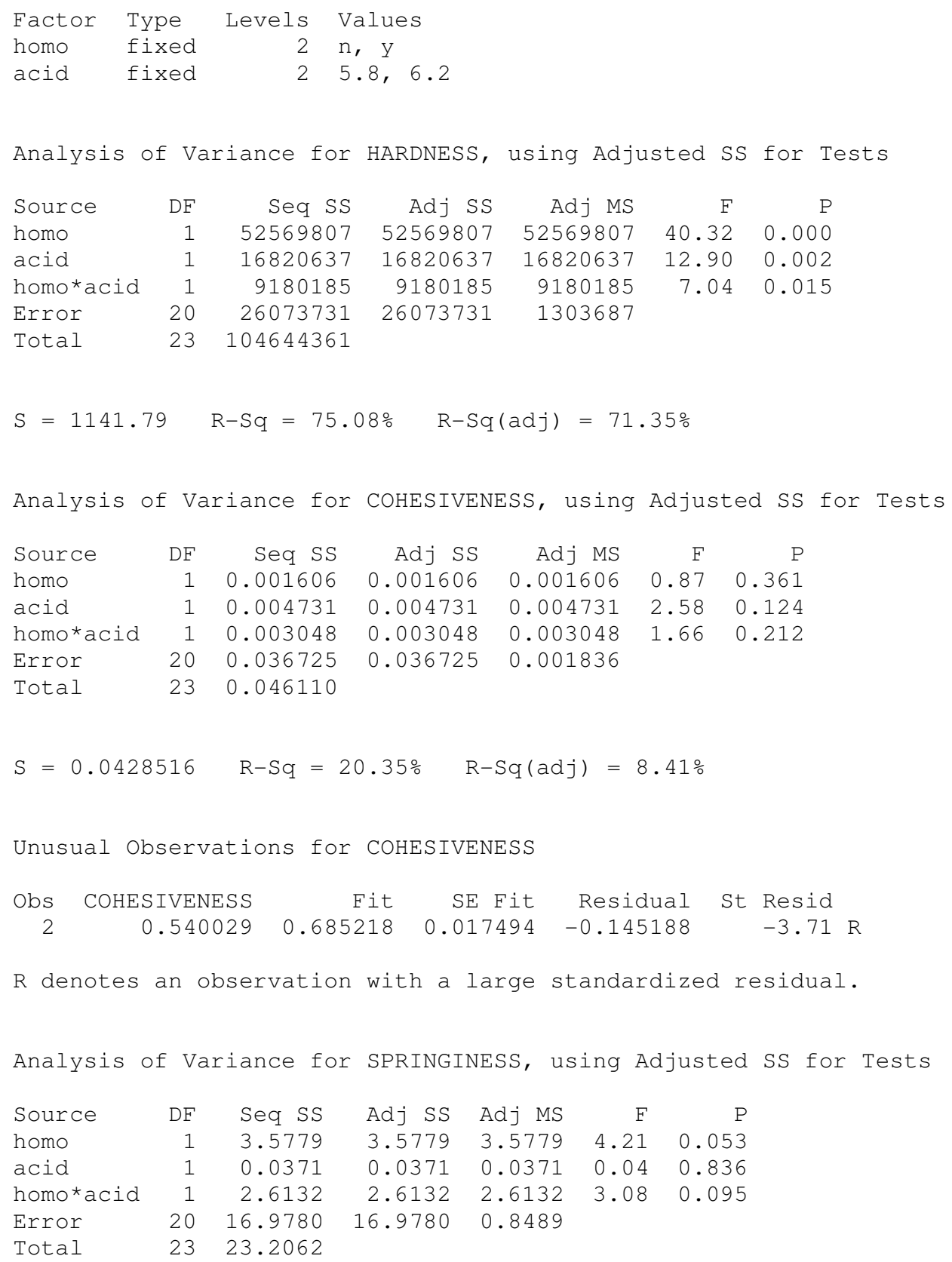




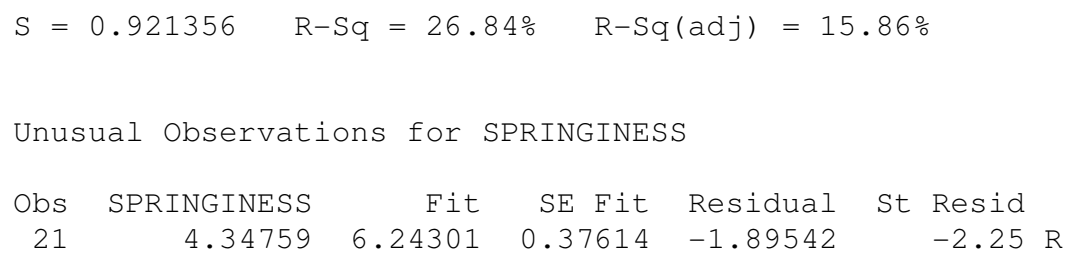

$\mathrm{R}$ denotes an observation with a large standardized residual.

Analysis of Variance for GUMMINESS, using Adjusted SS for Tests

$\begin{array}{lrrrrrr}\text { Source } & \text { DF } & \text { Seq SS } & \text { Adj SS } & \text { Adj MS } & \text { F } & P \\ \text { homo } & 1 & 30878475 & 30878475 & 30878475 & 38.82 & 0.000 \\ \text { acid } & 1 & 11594175 & 11594175 & 11594175 & 14.58 & 0.001 \\ \text { homo*acid } & 1 & 3713532 & 3713532 & 3713532 & 4.67 & 0.043 \\ \text { Error } & 20 & 15907250 & 15907250 & 795363 & & \\ \text { Total } & 23 & 62093431 & & & & \\ \text { S }=891.831 & \text { R-Sq }=74.38 \% & R-S q(\operatorname{adj})=70.54 \% & \end{array}$

Analysis of Variance for CHEWINESS, using Adjusted SS for Tests

$\begin{array}{lrrrrrr}\text { Source } & \text { DF } & \text { Seq SS } & \text { Adj SS } & \text { Adj MS } & \text { F } & P \\ \text { homo } & 1 & 2024122844 & 2024122844 & 2024122844 & 26.55 & 0.000 \\ \text { acid } & 1 & 349936039 & 349936039 & 349936039 & 4.59 & 0.045 \\ \text { homo*acid } & 1 & 24285263 & 24285263 & 24285263 & 0.32 & 0.579 \\ \text { Error } & 20 & 1524628785 & 1524628785 & 76231439 & & \\ \text { Total } & 23 & 3922972931 & & & & \\ & & & & & \\ \text { S }=8731.06 & \mathrm{R}-\mathrm{Sq}=61.14 \% & \mathrm{R}-\mathrm{Sq}(\mathrm{adj})=55.31 \% & & \end{array}$

Unusual Observations for CHEWINESS

Obs CHEWINESS Fit SE Fit Residual St Resid

$\begin{array}{llllll}14 & 65677.1 & 47277.7 & 3564.4 & 18399.4 & 2.31 \mathrm{R}\end{array}$

$\mathrm{R}$ denotes an observation with a large standardized residual.

Tukey 95.0\% Simultaneous Confidence Intervals Response Variable HARDNESS

All Pairwise Comparisons among Levels of acid acid $=5.8$ subtracted from:

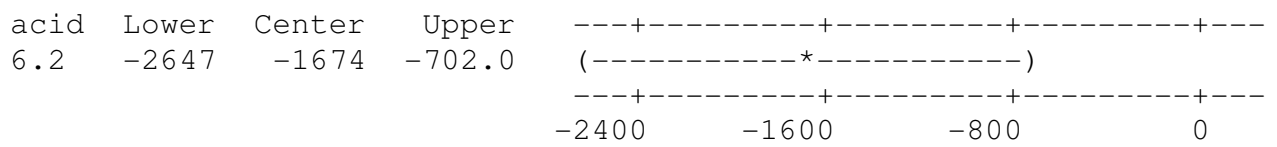

Tukey 95.0\% Simultaneous Confidence Intervals Response Variable HARDNESS

All Pairwise Comparisons among Levels of homo homo $=\mathrm{n}$ subtracted from: 


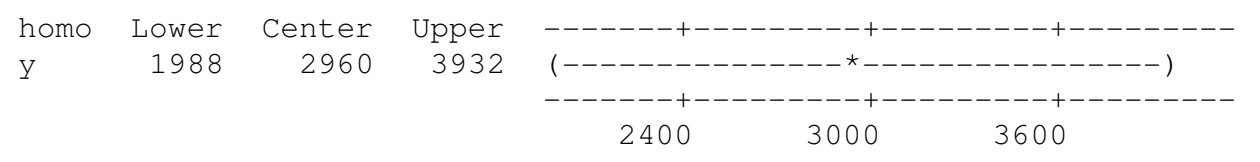

Tukey 95.0\% Simultaneous Confidence Intervals Response Variable HARDNESS

All Pairwise Comparisons among Levels of homo*acid

homo $=\mathrm{n}$

acid $=5.8$ subtracted from:

$\begin{array}{llrrr}\text { homo } & \text { acid } & \text { Lower } & \text { Center } & \text { Upper } \\ \mathrm{n} & 6.2 & -2283 & -437.4 & 1408 \\ \mathrm{y} & 5.8 & 2351 & 4197.0 & 6043 \\ \mathrm{y} & 6.2 & -560 & 1285.7 & 3132\end{array}$

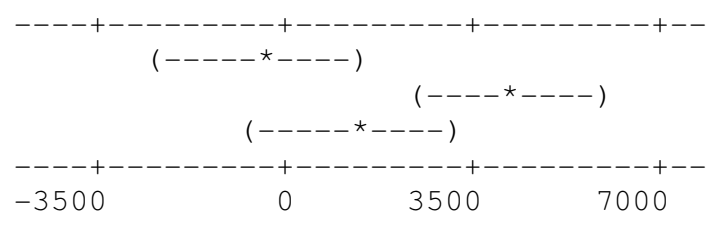

homo $=\mathrm{n}$

acid $=6.2$ subtracted from:

$\begin{array}{llrrr}\text { homo } & \text { acid } & \text { Lower } & \text { Center } & \text { Upper } \\ y & 5.8 & 2788.5 & 4634 & 6480\end{array}$

$\begin{array}{lllll}\mathrm{y} & 5.8 & 2788.5 & 4634 & 6480 \\ \mathrm{y} & 6.2 & -122.8 & 1723 & 3569\end{array}$

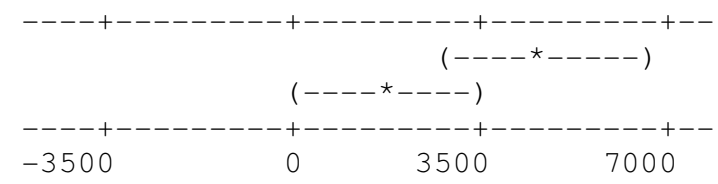

homo $=y$

acid $=5.8$ subtracted from:

homo acid Lower Center Upper

y $\quad 6.2 \quad-4757 \quad-2911-1065$

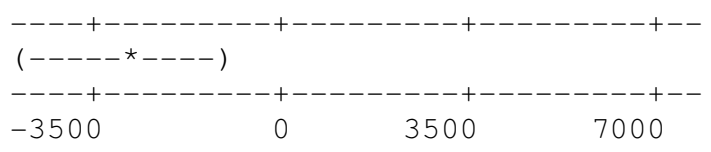

Tukey 95.0\% Simultaneous Confidence Intervals Response Variable COHESIVENESS

All Pairwise Comparisons among Levels of acid acid $=5.8$ subtracted from:

\begin{tabular}{|c|c|c|c|c|}
\hline $\begin{array}{l}\operatorname{acid} \\
6.2\end{array}$ & $\begin{array}{r}\text { Lower } \\
-0.06457\end{array}$ & $\begin{array}{r}\text { Center } \\
-0.02808\end{array}$ & $\begin{array}{r}\text { Upper } \\
0.008411\end{array}$ & $\begin{array}{c}--+---------+---------+---------+---- \\
(-------------------\star-------------------) \\
---+---------+---------+---------+----\end{array}$ \\
\hline & & & & -0.020 \\
\hline
\end{tabular}

Tukey 95.0\% Simultaneous Confidence Intervals Response Variable COHESIVENESS

All Pairwise Comparisons among Levels of homo homo $=\mathrm{n}$ subtracted from:

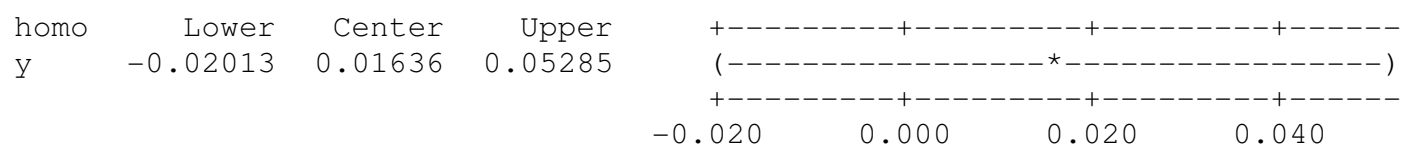

Tukey 95.0\% Simultaneous Confidence Intervals Response Variable COHESIVENESS 


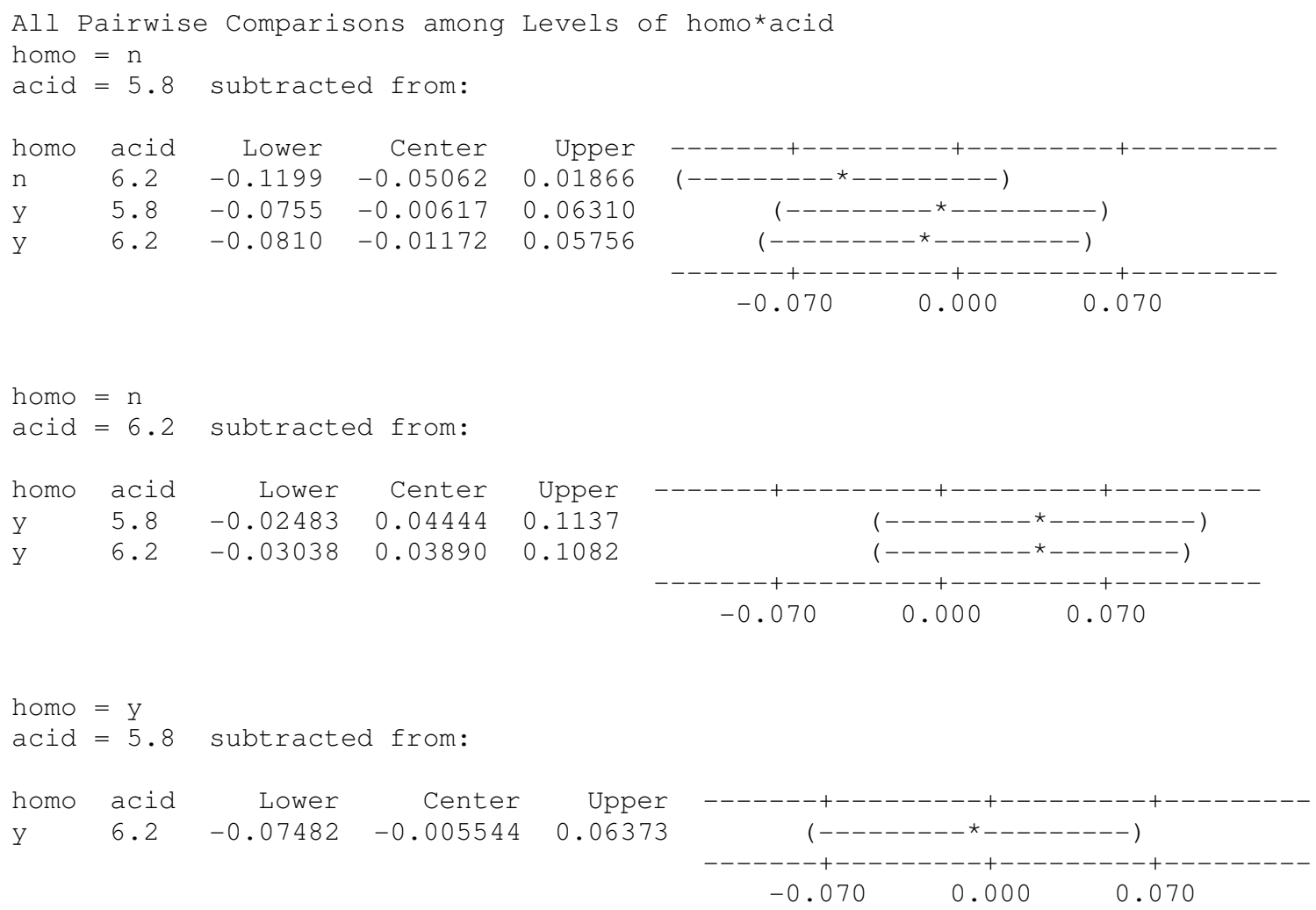

Tukey 95.0\% Simultaneous Confidence Intervals

Response Variable SPRINGINESS

All Pairwise Comparisons among Levels of acid

acid $=5.8$ subtracted from:

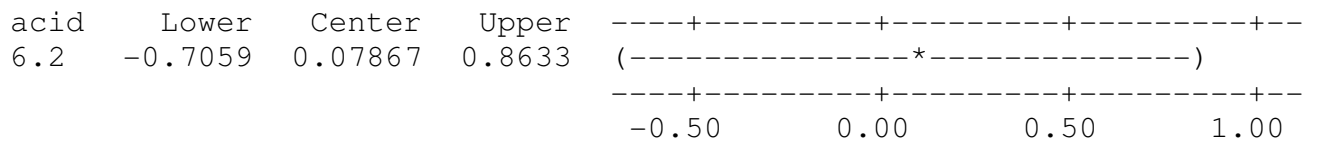

Tukey 95.0\% Simultaneous Confidence Intervals Response Variable SPRINGINESS

All Pairwise Comparisons among Levels of homo homo $=\mathrm{n}$ subtracted from:

$\begin{array}{lrrr}\text { homo } & \text { Lower } & \text { Center } & \text { Upper } \\ y & -0.01241 & 0.7722 & 1.557\end{array}$

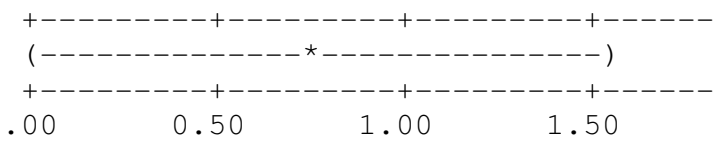

Tukey 95.0\% Simultaneous Confidence Intervals Response Variable SPRINGINESS

All Pairwise Comparisons among Levels of homo*acid

homo $=\mathrm{n}$

acid $=5.8$ subtracted from:

$\begin{array}{llrrrc}\text { homo } & \text { acid } & \text { Lower } & \text { Center } & \text { Upper } & ----+---------+---------+---------+-- \\ \mathrm{n} & 6.2 & -2.071 & -0.5813 & 0.9082 & (---------\star---------) \\ \mathrm{y} & 5.8 & -1.377 & 0.1123 & 1.6018 & (---------\star---------) \\ \mathrm{y} & 6.2 & -0.639 & 0.8509 & 2.3404 & (---------\star---------)\end{array}$



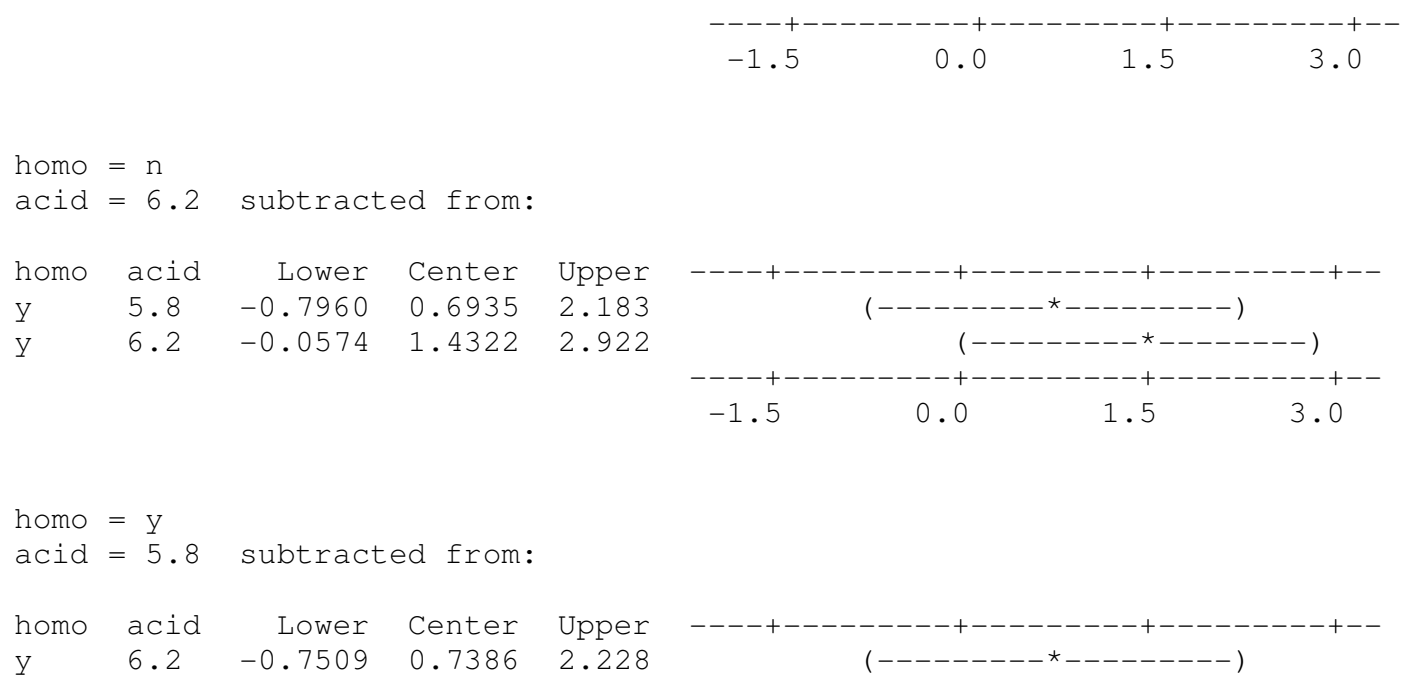

Tukey 95.0\% Simultaneous Confidence Intervals Response Variable GUMMINESS

All Pairwise Comparisons among Levels of acid acid $=5.8$ subtracted from:
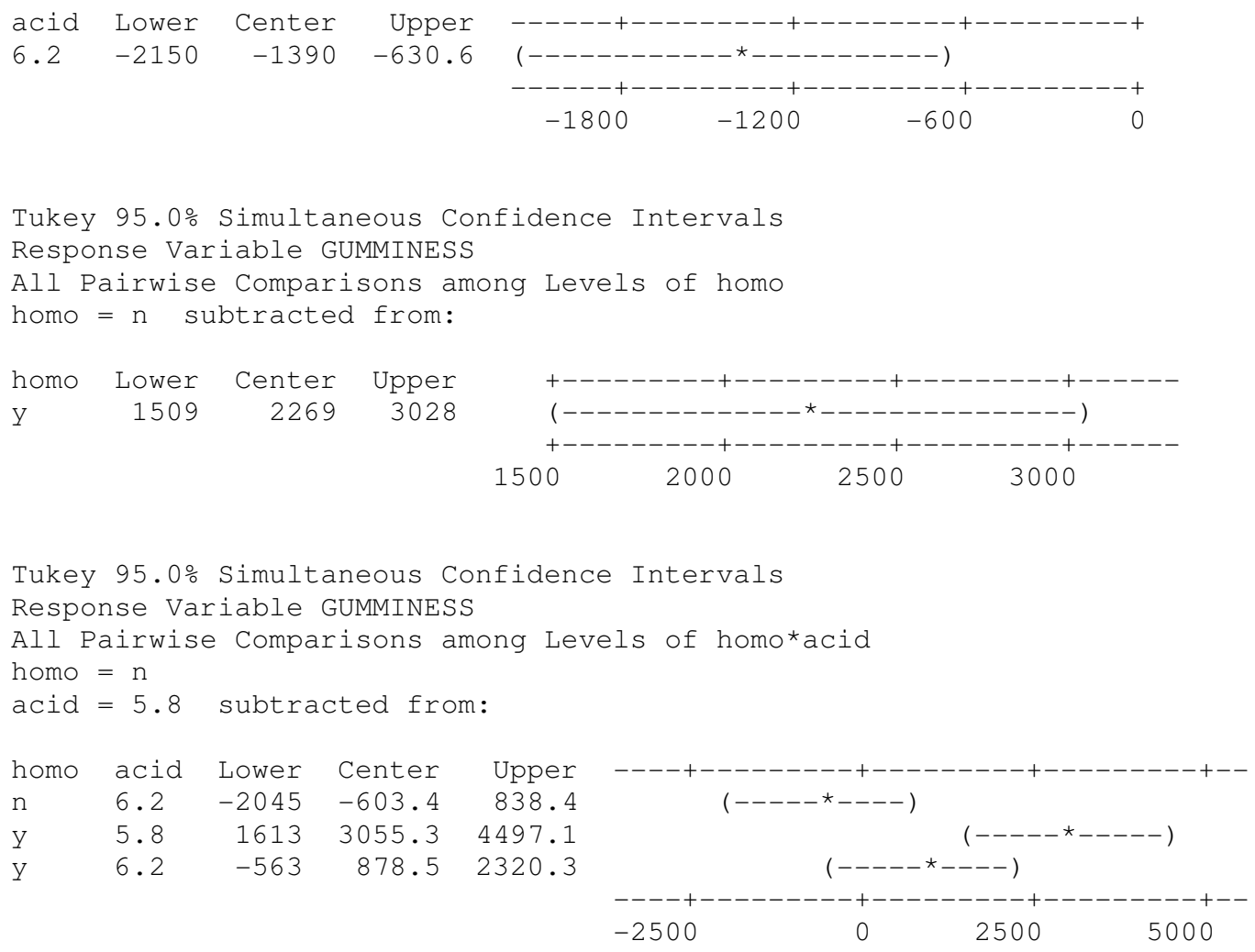


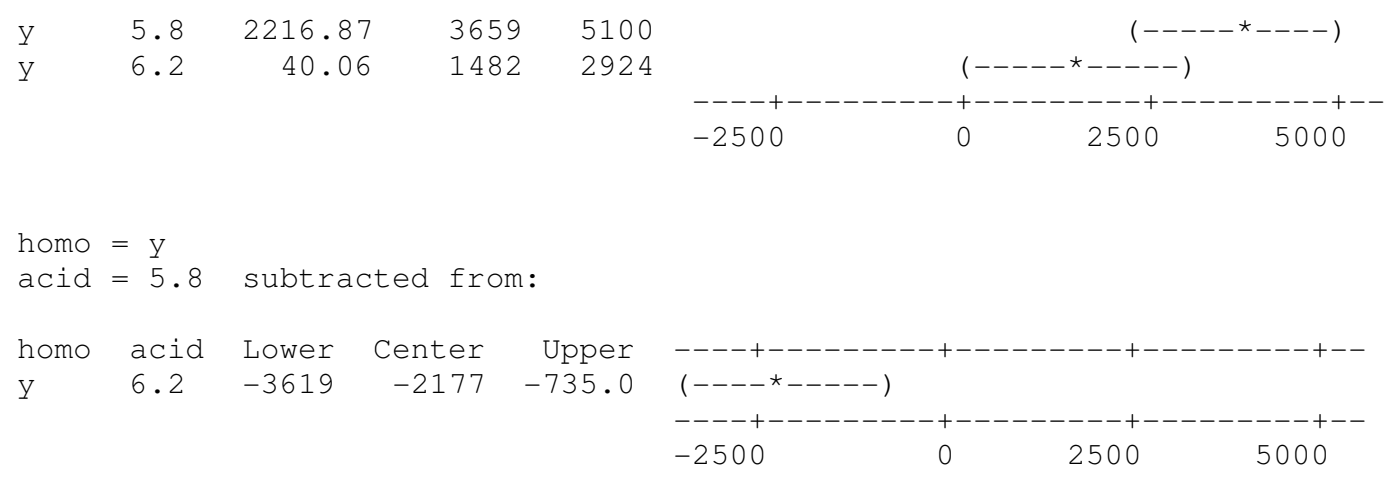

Tukey 95.0\% Simultaneous Confidence Intervals Response Variable CHEWINESS

All Pairwise Comparisons among Levels of acid acid $=5.8$ subtracted from:

acid Lower Center Upper

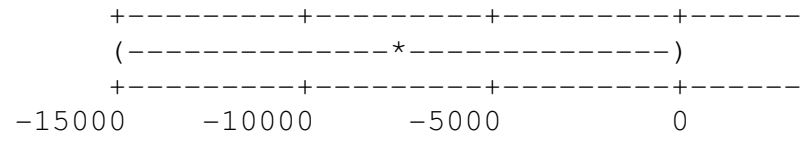

Tukey 95.0\% Simultaneous Confidence Intervals Response Variable CHEWINESS

All Pairwise Comparisons among Levels of homo homo $=\mathrm{n}$ subtracted from:

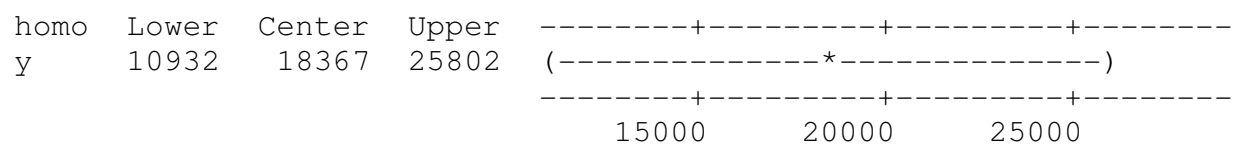

Tukey 95.0\% Simultaneous Confidence Intervals Response Variable CHEWINESS

All Pairwise Comparisons among Levels of homo*acid

homo $=\mathrm{n}$

acid $=5.8$ subtracted from:

$\begin{array}{llrrr}\text { homo } & \text { acid } & \text { Lower } & \text { Center } & \text { Upper } \\ \mathrm{n} & 6.2 & -19740 & -5625 & 8490 \\ \mathrm{y} & 5.8 & 6264 & 20379 & 34494 \\ \mathrm{y} & 6.2 & -3385 & 10730 & 24845\end{array}$
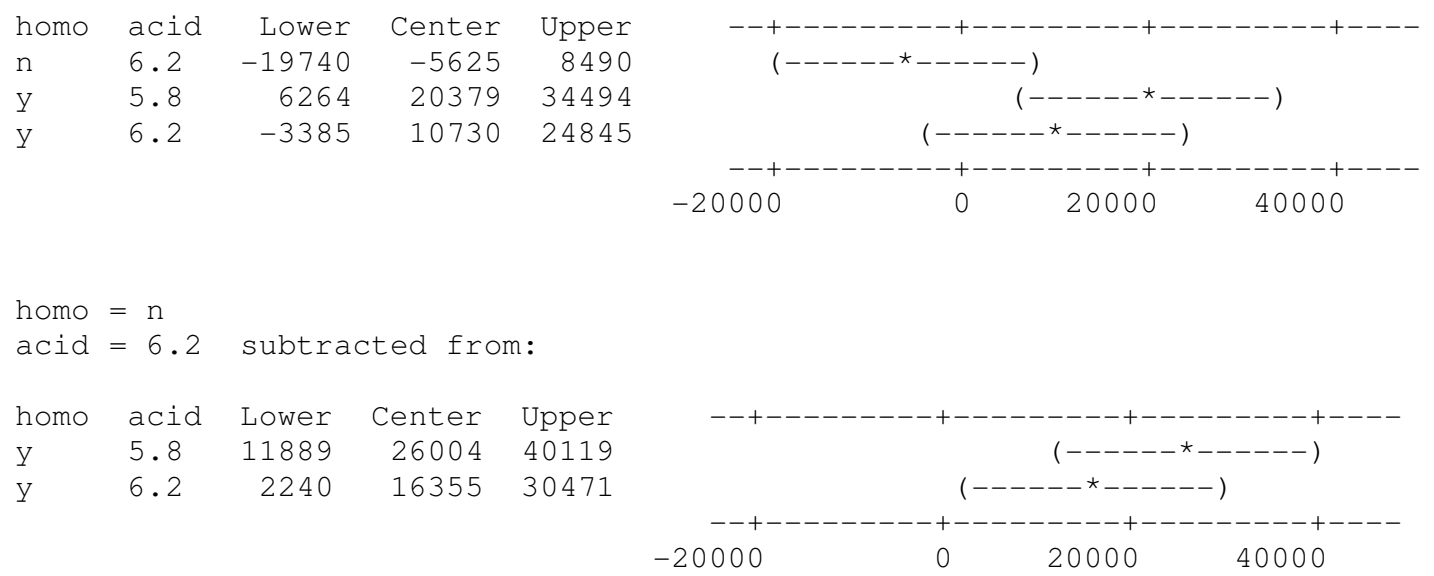

homo $=y$

acid $=5.8$ subtracted from: 
homo acid Lower Center Upper

y $\quad 6.2 \quad-23764$

$-96494466$

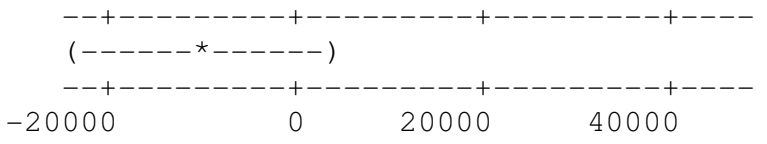




\section{Limited focus group survey Statistical Analysis}

Tally for Discrete Variables: tried be4? (, Difference i, preference (, ...

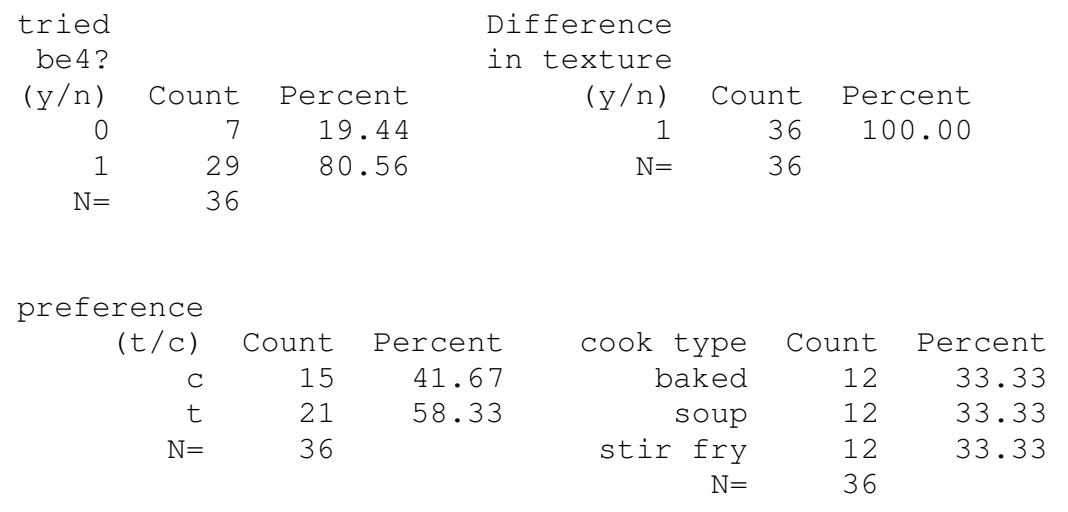

Tabulated statistics: preference ( $t / c)$, cook type

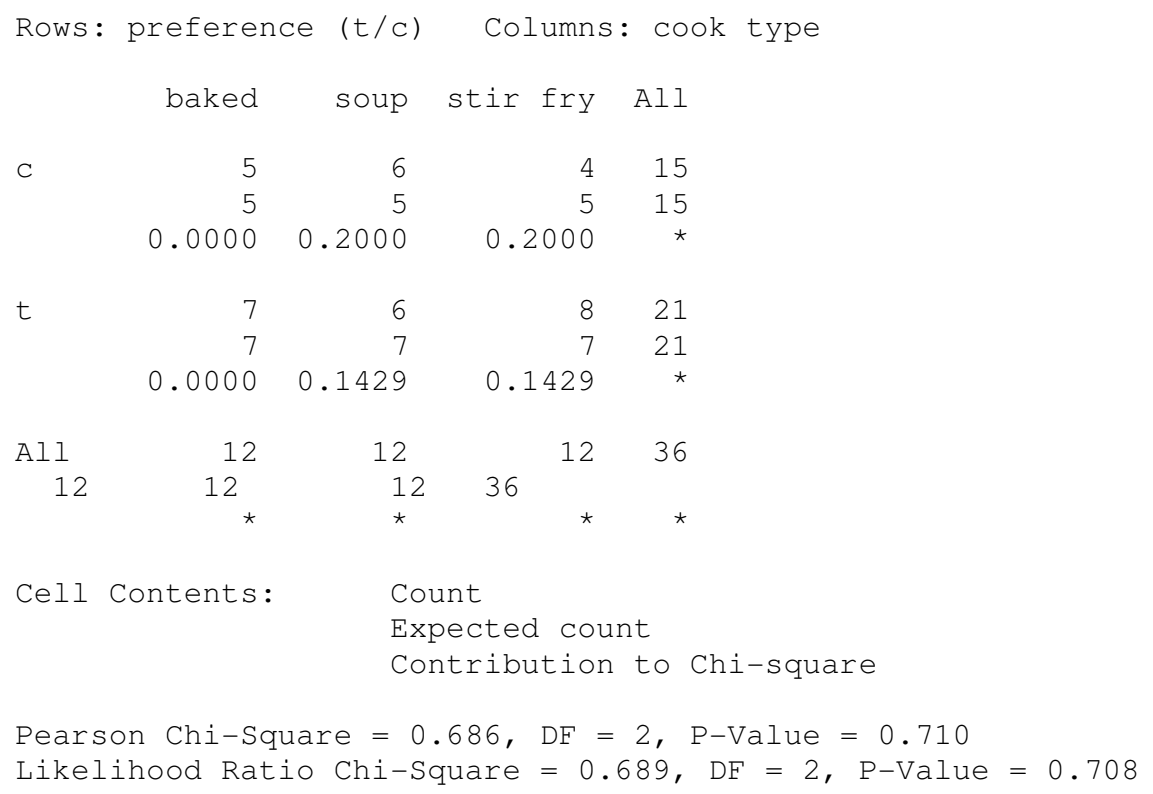

Tabulated statistics: tried be4? $(\mathrm{y} / \mathrm{n})$, preference $(\mathrm{t} / \mathrm{c})$

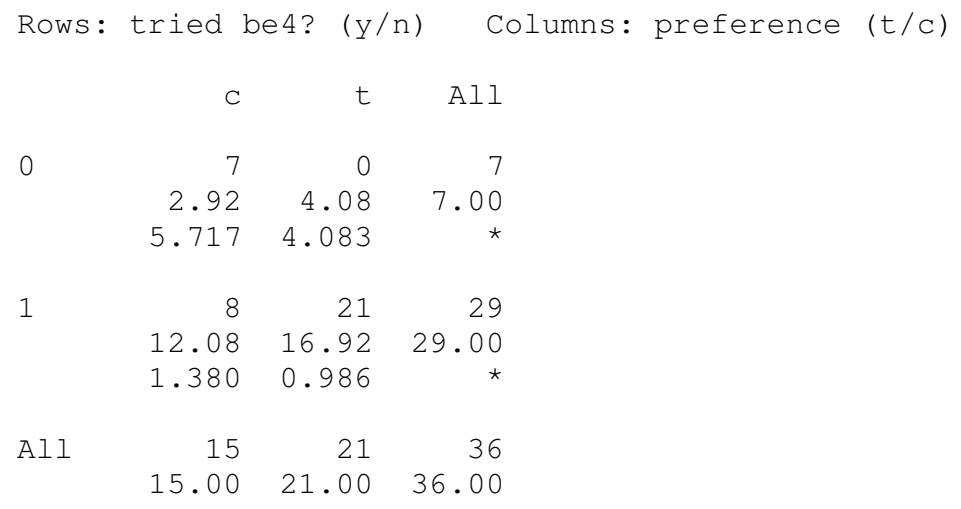




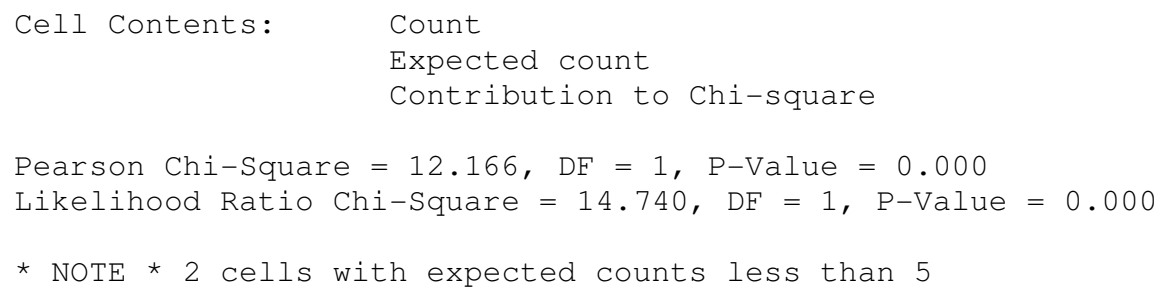

$\begin{array}{rrrr}\text { baked } & \text { soup } & \begin{array}{r}\text { stir } \\ \text { fry }\end{array} & \text { All } \\ & & & \\ 3 & 2 & 2 & 7 \\ 9 & 10 & 10 & 29 \\ 12 & 12 & 12 & 36\end{array}$

Test and $\mathrm{Cl}$ for One Proportion: preference (t/c)

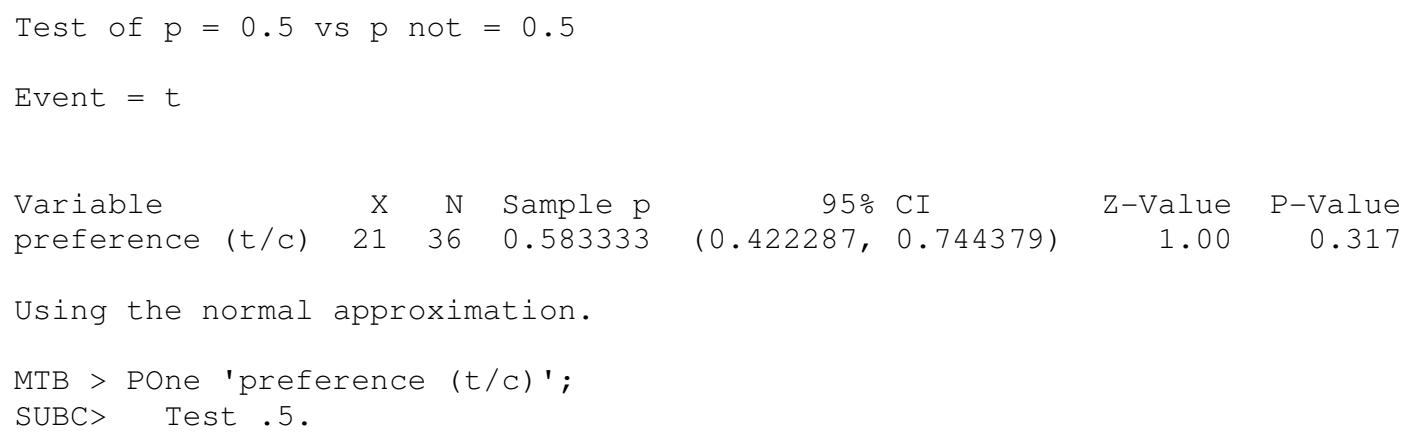

Test and $\mathrm{Cl}$ for One Proportion: preference ( $\mathrm{t} / \mathrm{c})$

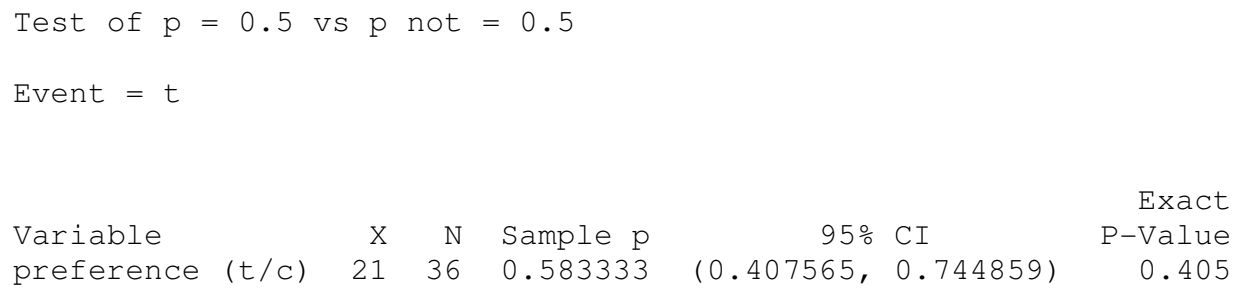




\section{Questionnaire of limited focus group survey:}

\section{SENSORY TEXTURE EVALUATION OF FOOD APPLICATION}

\subsection{Baking}

You have been given two samples of baked products which are similar in contents except one contains soy based curd (tofu) and the other contains milk based food. Please evaluate the both the products and answer following questions specific to the texture of cheese/tofu.

Name of panelist :

1. Have you ever had baked tofu(soy bean curd) before ? (yes/no/I don't know)

2. Is there any difference in terms of texture of tofu/cheese in both the products? What is the most prominent difference between sample A and sample B in terms of texture?

3. Overall, which sample of baked products do you prefer ? why? 


\section{SENSORY TEXTURE EVALUATION OF FOOD APPLICATION}

\subsection{Miso vegetable soup}

You have been given two samples of soup products which are similar in contents except one contains soy based curd (tofu) and the other contains milk based food. Please evaluate the both the products and answer following questions specific to the texture of tofu/cheese.

Name of panelist:

1. Have you ever had miso soup before? (yes/no/I don't know)

2. Is there any difference in terms of texture of tofu/cheese in both the products? What is the most prominent difference between sample A and sample B in terms of texture?

3. Overall, which sample of soup products do you prefer? why? 


\section{SENSORY TEXTURE EVALUATION OF FOOD APPLICATION}

\subsection{STIR FRYING}

You have been given two samples of stir-fried products which are similar in contents except one contains soy based food (tofu) and the other contains milk based food. Please evaluate the both the products and answer following questions specific to the texture of cheese/tofu.

Name of panelist :

1. Have you ever had stir-fried tofu(soy bean curd) before ? (yes/no/I don't know)

2. Is there any difference in terms of texture of tofu/cheese in both the products? What is the most prominent difference between sample A and sample B in terms of texture?

3. Overall, which sample of stir-fried products do you prefer? why? 